\title{
Het recht op zorg voor de gezondheid van onrechtmatig verblijvende vreemdelingen in Nederland
}

V.L. Derckx 


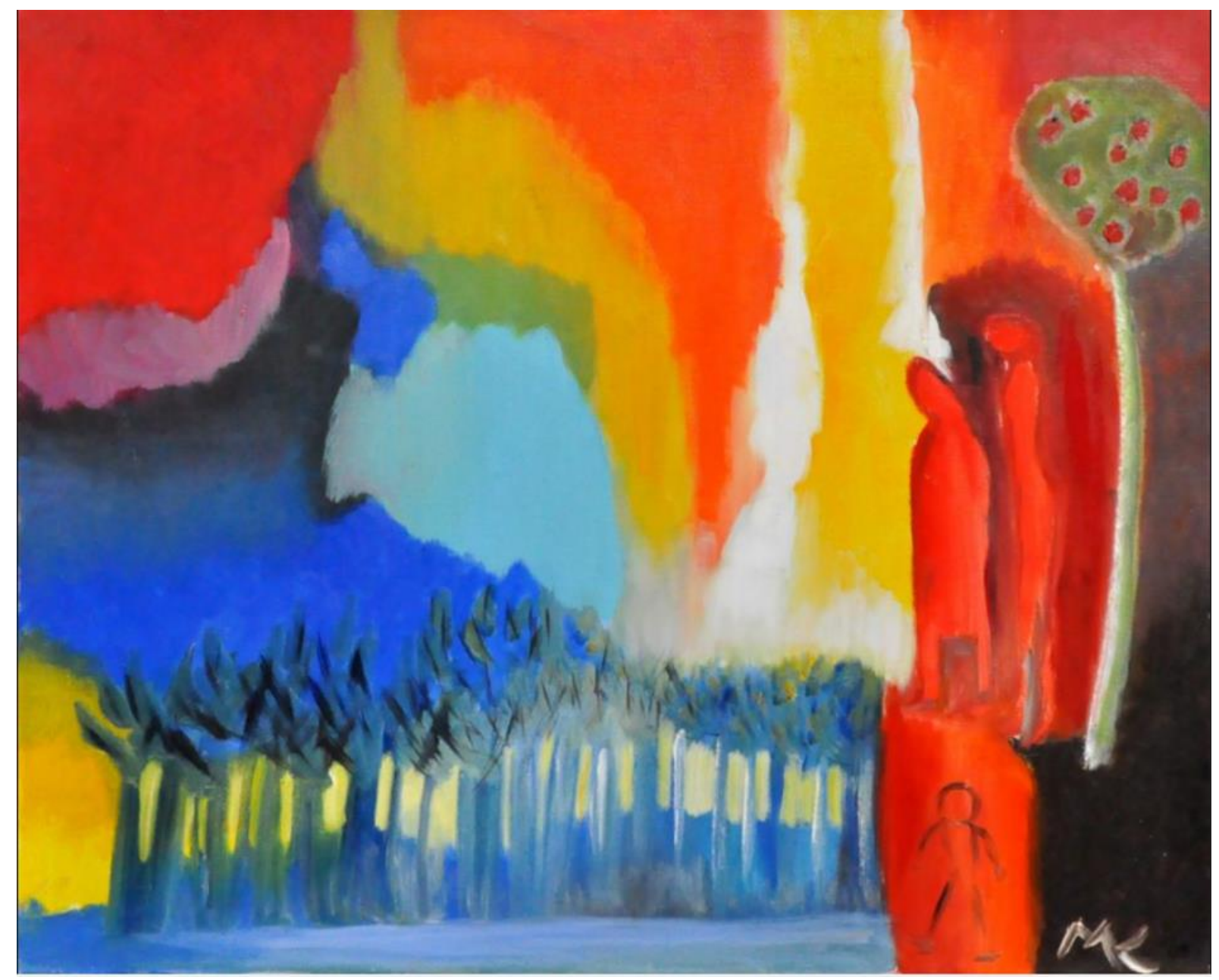

Maria Koster: 'De Levensweg' 


\section{Het recht op zorg voor de gezondheid van onrechtmatig verblijvende vreemdelingen in Nederland}

The right to health care of irregular migrants in the Netherlands

(with a summary in English)

\section{Proefschrift}

ter verkrijging van de graad van doctor aan de

Universiteit Utrecht

op gezag van de

rector magnificus, prof. dr. H.R.B.M. Kummeling,

ingevolge het besluit van het college voor promoties

in het openbaar te verdedigen op

woensdag 31 maart 2021 des middags te 4.15 uur

door

Veelke Laetitia Derckx

geboren op 4 oktober 1972

te Arnhem 
Promotor:

Prof. dr. J.G. Sijmons

\section{Copromotor:}

Dr. M. Van Kogelenberg 


\section{Voorwoord}

In 2006 werd ik geraakt door een documentaire van PREMtime. Het ging over de zorgverlening aan een kind zonder verblijfsstatus. Dit jongetje ontving te laat medische zorg voor ernstige diarree. Als gevolg van uitdroging raakte hij gehandicapt. Vervolgens verbleven hij en zijn moeder anderhalf jaar in het AMC, omdat geen enkele instelling het kind wilde opnemen vanwege diens onverzekerde status. Pas toen zijn moeder uit de ouderlijke macht werd ontzet, waren een verblijfsvergunning en een verzekering mogelijk. ${ }^{1}$

Deze casus vormde destijds voor mij aanleiding om onderzoek te gaan doen naar het recht op zorg voor de gezondheid van onrechtmatig verblijvende mensen. In 2017 heb ik dit onderzoek als buitenpromovendus hervat. Met dit proefschrift hoop ik bij te dragen aan de versterking van hun rechtspositie, met name die van kinderen.

Meerdere mensen hebben een cruciale rol gespeeld bij het voltooien van dit proefschrift. Een aantal van hen wil ik in het bijzonder noemen. Mijn promotor prof. dr. Jaap Sijmons bedank ik voor zijn vertrouwen en begeleiding. Jaap: begonnen onze gesprekken meestal over muziek, al gauw nam je mee naar gezondheidsrechtelijke en filosofische vergezichten. Dank voor het meewandelen tijdens dit promotietraject en voor de prettige samenwerking in de afgelopen jaren. Dr. Martijn van Kogelenberg bedank ik voor zijn rollen, in eerste instantie als dagelijks begeleider en later als copromotor. Martijn: al zijn de koffiemomenten de afgelopen maanden noodgedwongen vervangen door Teams of de telefoon, je ondersteunende en relativerende gesprekken bleven me motiveren.

Het Molengraaff Instituut voor Privaatrecht, in het bijzonder het Dagelijks Bestuur, ben ik erkentelijk voor de gastvrijheid en ondersteuning. Mijn collega's van het Molengraaff Instituut bedank ik voor de warme belangstelling tijdens mijn promotieproces. Zonder anderen te kort te willen doen, noem ik speciaal Shosha Wiznitzer en Soraya Bou-Sfia, die mij in de laatste fase een extra duwtje in de rug gaven. Prof. mr. Henriette Roscam Abbing begeleidde mij in eerste instantie en bleef ook daarna belangstellend en betrokken. Drs. Marjan Mensinga en drs. Evert Bloemen, beiden werkzaam bij Pharos, noem ik graag voor het goede contact en voor het delen van informatie uit het veld. Mr. Monique Biesaart tenslotte ben ik erkentelijk voor het nalezen van de tekst.

Mijn moeder dank ik voor de kleurrijke illustratie. Mijn vader zou dit proefschrift met veel belangstelling hebben gelezen. Marius, Luca en Florine, dank voor jullie liefdevolle steun en geduld!

Veelke Derckx

Bilthoven, 14 augustus 2020

${ }^{1}$ Zie ook De Visser, de Volkskrant 17 juli 2006. 


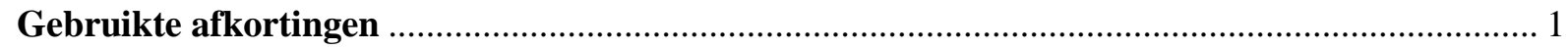

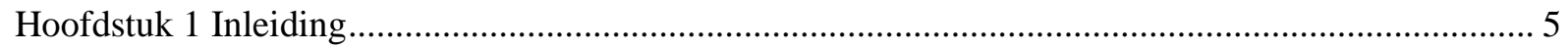

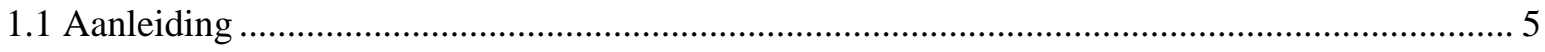

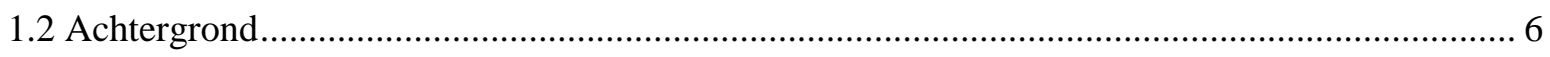

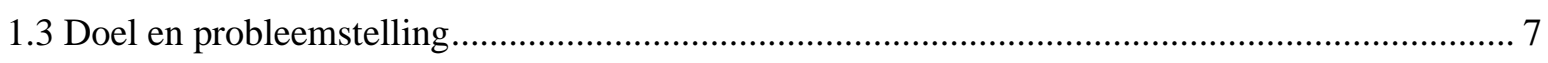

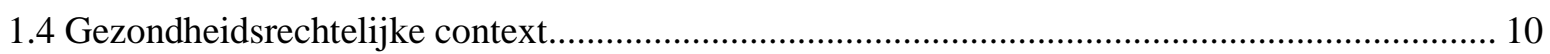

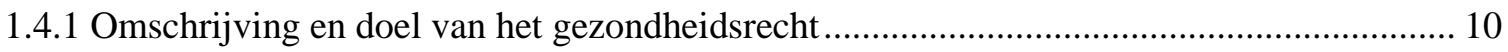

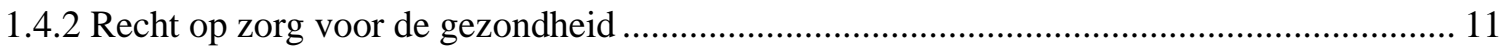

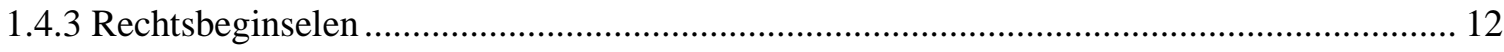

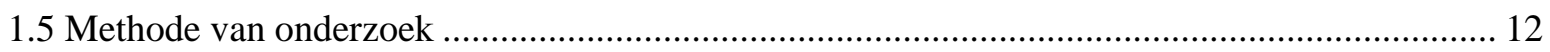

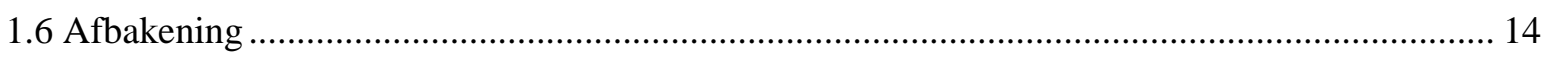

1.7 De vreemdeling zonder rechtmatig verblijf (voorheen: "illegalen"): terminologie .................... 15

Hoofdstuk 2 Introductie: de vreemdeling, diens gezondheid en gebruik van de gezondheidszorg....... 17

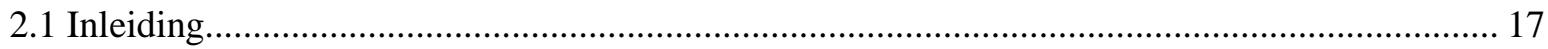

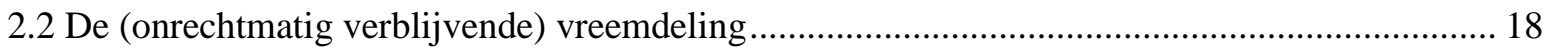

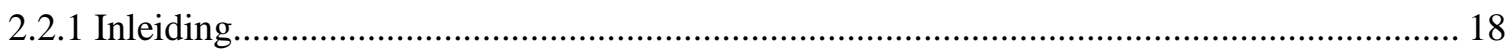

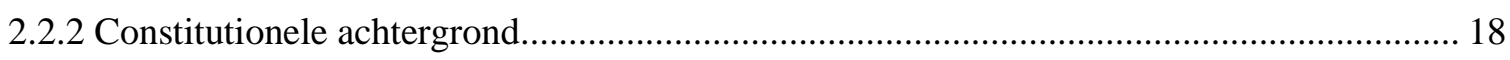

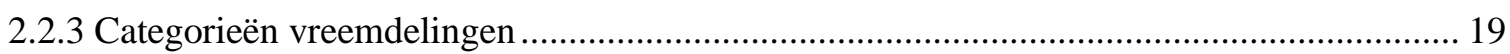

2.3 Gezondheid, gezondheidsdeterminanten en publieke gezondheidszorg ................................... 22

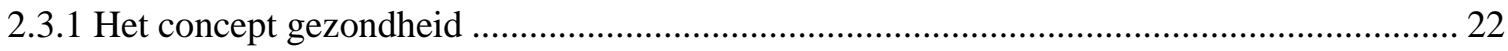

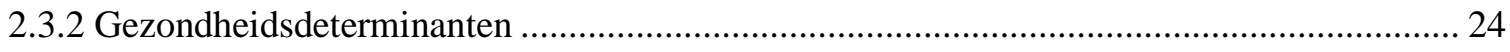

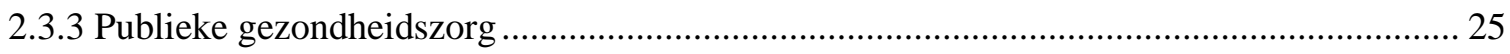

2.4 Algemene gezondheid en gezondheidsproblemen van (irreguliere) migranten .......................... 25

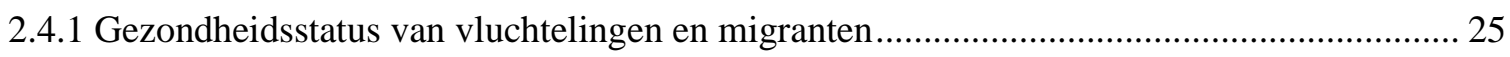

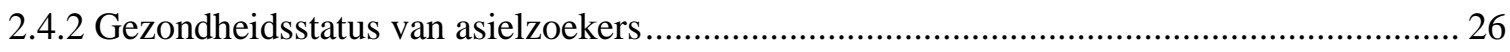

2.4.3 Gezondheidsstatus van vreemdelingen in vreemdelingendetentie ...................................... 26

2.4.4 Gezondheidsstatus van vreemdelingen zonder rechtmatig verblijf ...................................... 27

2.5 Specifieke gezondheidsproblemen van vreemdelingen zonder rechtmatig verblijf .................... 28

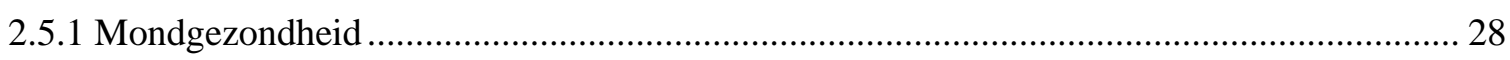

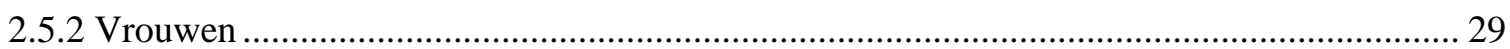

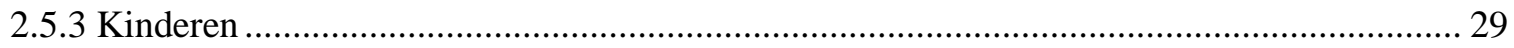

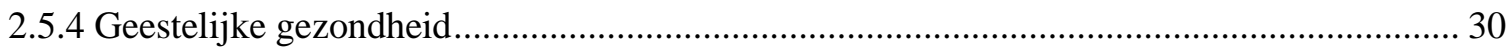

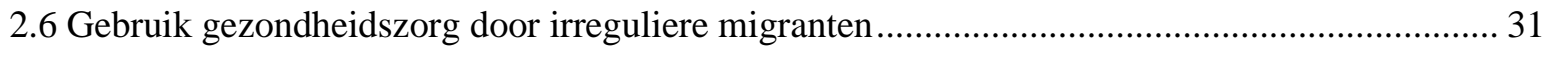

2.6.1 Kloof tussen aangeboden gezondheidszorg en gebruik ..................................................... 31

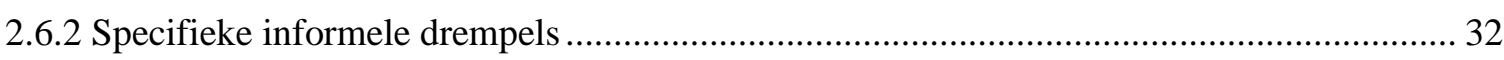

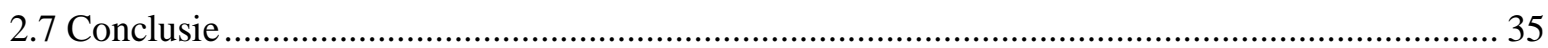


Hoofdstuk 3 Medische zorg aan vreemdelingen zonder rechtmatig verblijf: achtergrond wettelijke

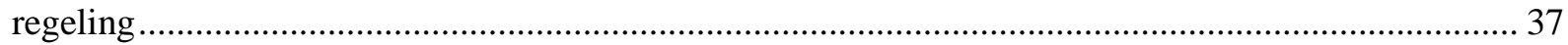

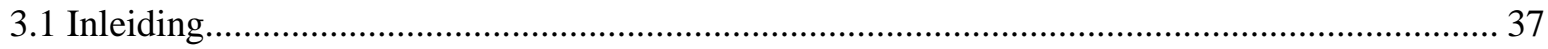

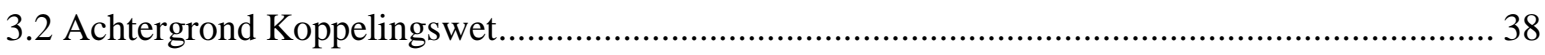

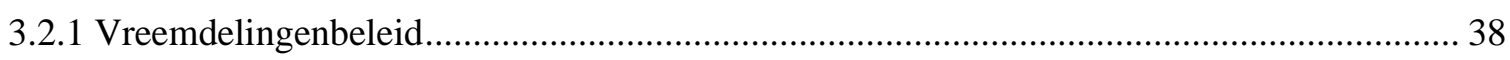

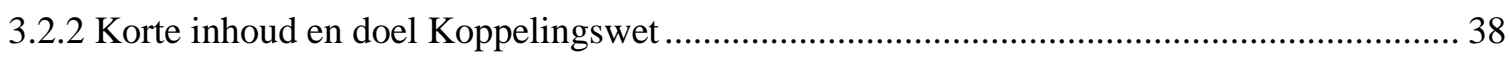

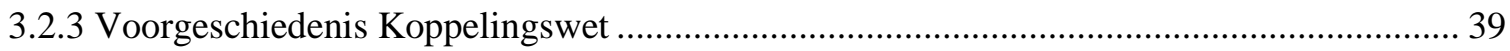

3.3 Uitwerking koppelingsbeginsel voor de gezondheidszorg .................................................... 43

3.3.1 Aanspraak op ziektekostenverzekeringen vóór de Koppelingswet ....................................... 43

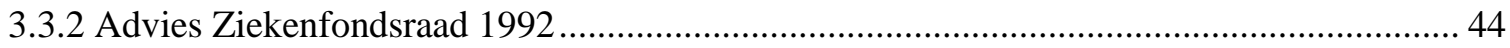

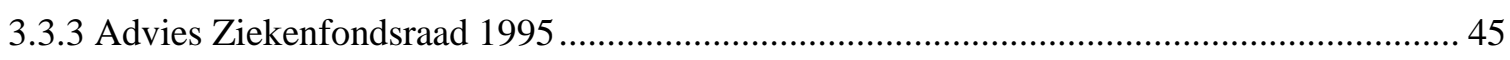

3.3.4 Uitzondering op het koppelingsbeginsel: (acute) medisch noodzakelijke zorg ................... 45

3.4 Zorgen over (mogelijke) gevolgen van de Koppelingswet voor de gezondheidszorg ................ 49

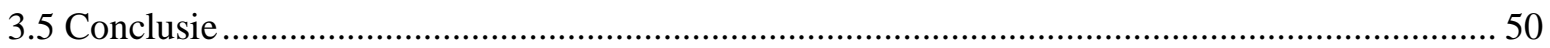

Hoofdstuk 4 Financiering van medische zorg aan vreemdelingen zonder rechtmatig verblijf ............ 51

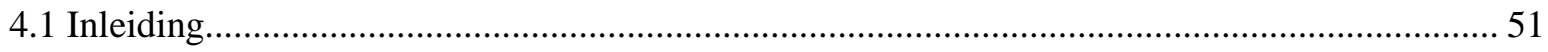

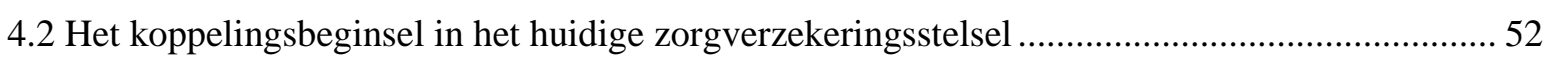

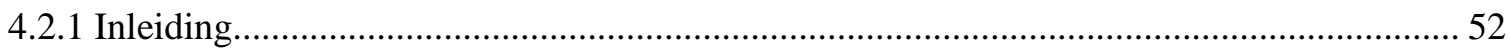

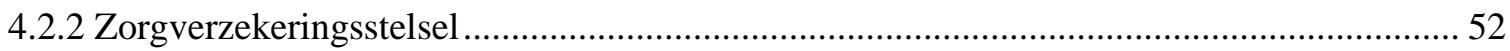

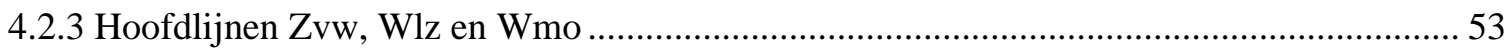

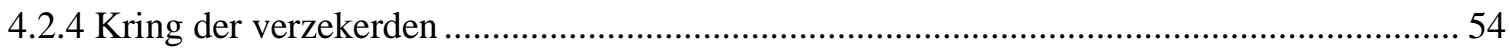

4.2.5 Uitzondering op het koppelingsbeginsel in individuele gevallen ....................................... 56

4.3 Financiering van medisch noodzakelijke zorg voor onrechtmatig verblijvende vreemdelingen 56

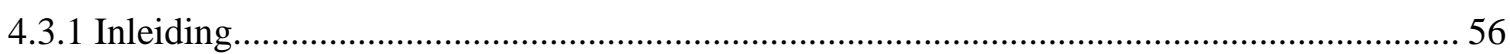

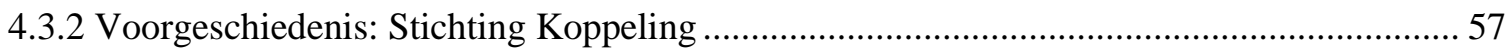

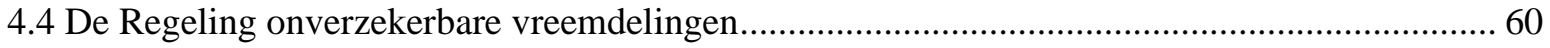

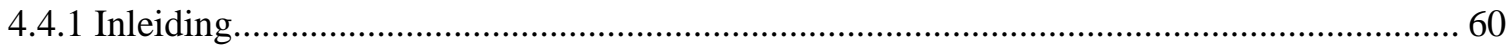

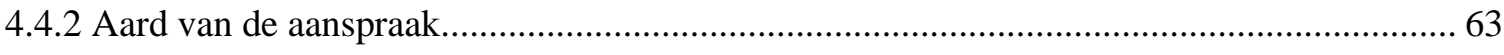

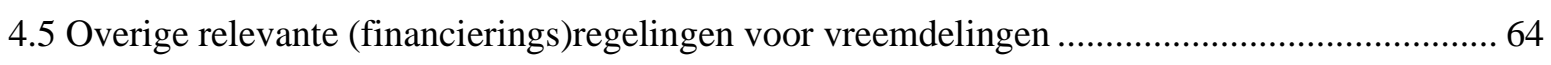

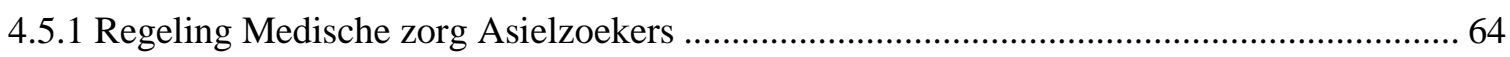

4.5.2 Regeling verstrekkingen bepaalde categorieën vreemdelingen............................................ 65

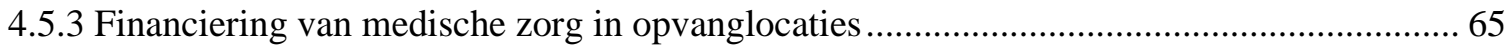

4.5.4 Financiering van medische zorg voor vreemdelingen in detentiecentra .............................. 66

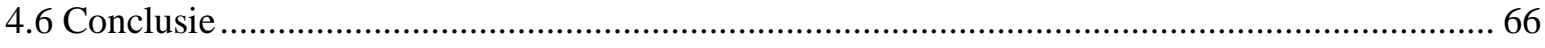

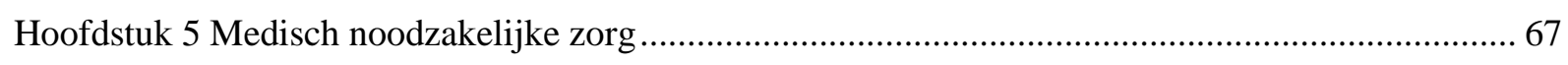

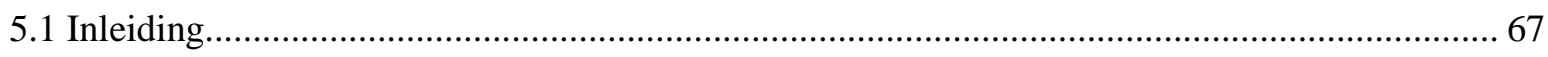

5.2 (Parlementaire) voorgeschiedenis: van 'acute noodsituaties' tot 'medisch noodzakelijke zorg' 68

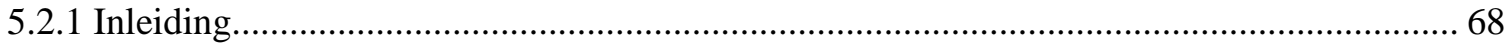


5.2.2 Commissie Zeevalking/wetsontwerp Koppelingswet: 'acute medische noodsituaties' ....... 68

5.2.3 Kritiek op formulering 'acute medische noodsituaties' ........................................................ 69

5.2.4 Wijziging ‘acute noodsituaties' in 'medisch noodzakelijke zorg'. ..................................... 72

5.3 Interpretatie van 'medisch noodzakelijke zorg' na inwerkingtreding Koppelingswet................ 73

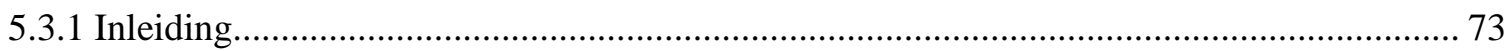

5.3.2 Interpretatie van 'medisch noodzakelijke zorg' door het Koppelingsfonds en toenmalig

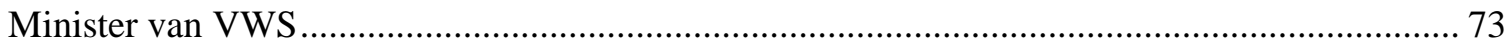

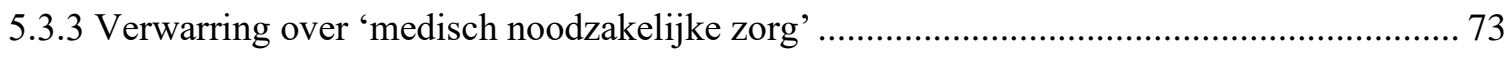

5.3.4 Commissie Smeets: onzekere verblijfsstatus speelt een rol ............................................... 74

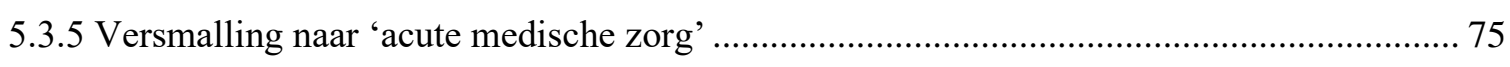

5.4 Invulling van het begrip 'medisch noodzakelijke zorg' door beroepsgroepen........................... 77

5.5 Medisch-ethische overwegingen met betrekking tot het begrip medisch noodzakelijke zorg .... 77

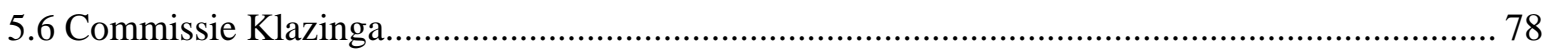

5.7 Verhouding medisch noodzakelijke zorg met basispakket $\mathrm{Zvw}$............................................. 79

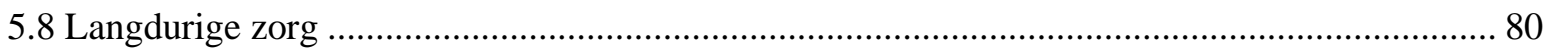

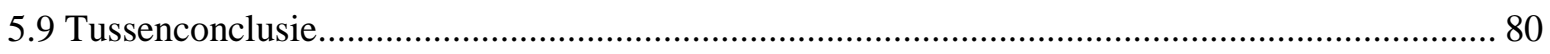

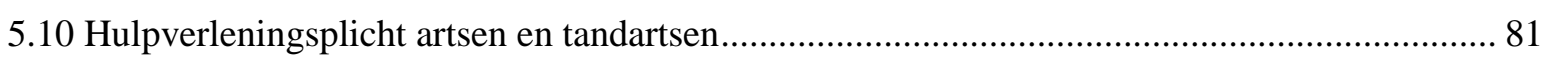

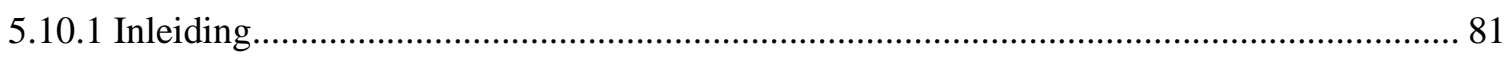

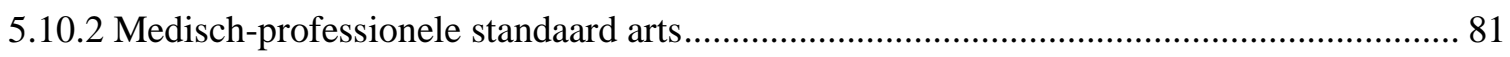

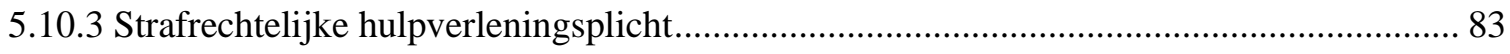

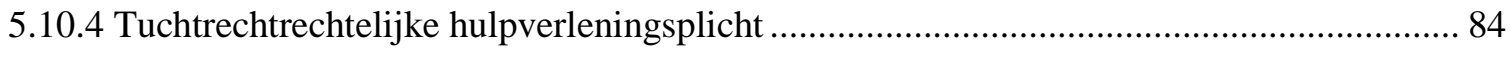

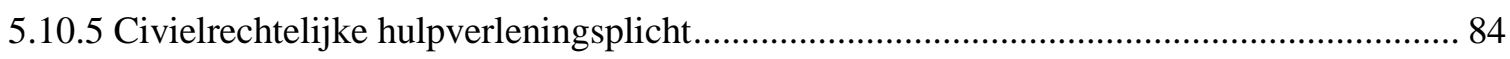

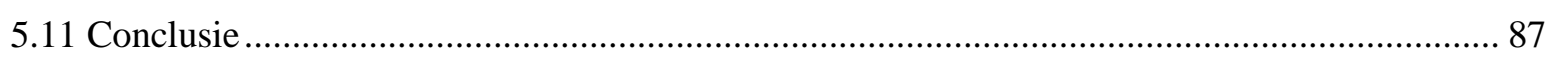

Hoofdstuk 6 Recht op zorg voor de gezondheid: internationaal kader ............................................. 89

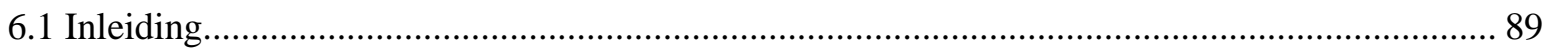

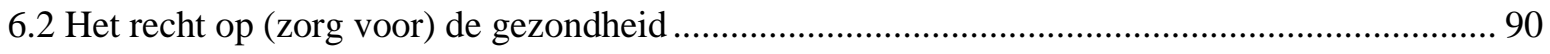

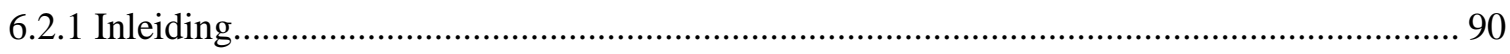

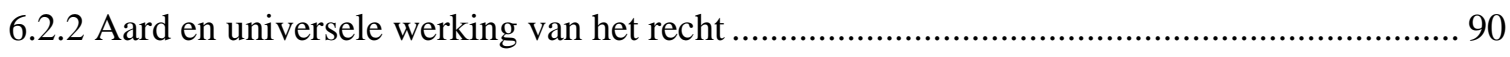

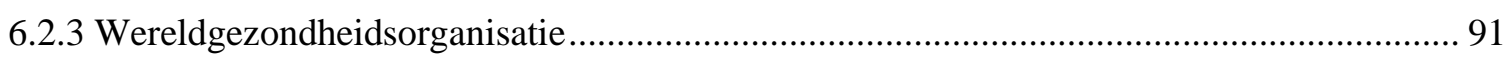

6.2.4 Universele Verklaring voor de Rechten van de Mens ........................................................ 93

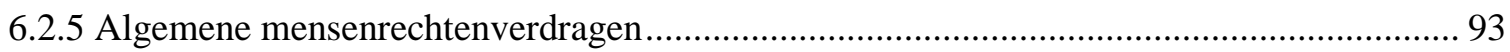

6.2.6 Internationaal Verdrag inzake economische, sociale en culturele rechten (IVESCR) ......... 95

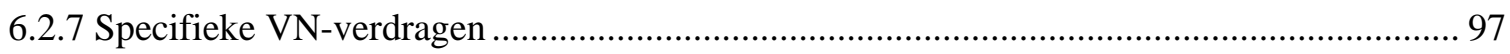

6.2.8 Het recht op zorg voor de gezondheid van irreguliere migranten ..................................... 98

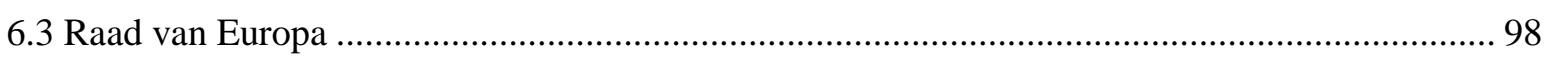

6.3.1 Europees Sociaal Handvest (herzien): Recht op bescherming van gezondheid en sociale en

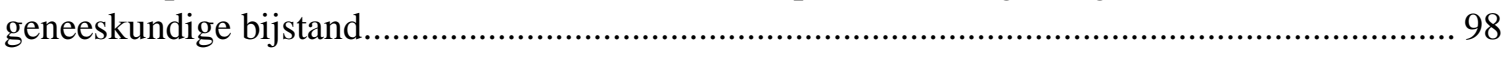

6.3.2 Europees Sociaal Handvest (herzien): Personele werkingssfeer ......................................... 99 
6.3.3 Recht op zorg voor de gezondheid van irreguliere migranten......................................... 100

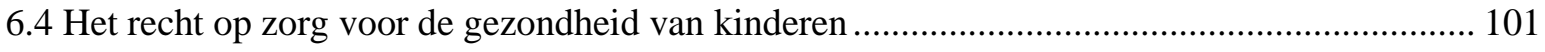

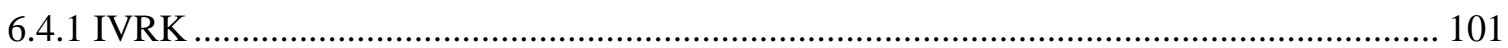

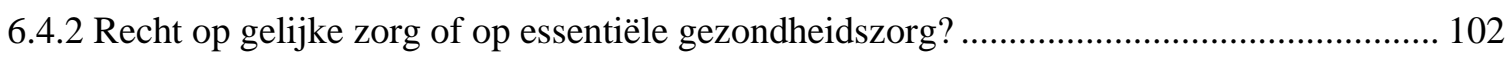

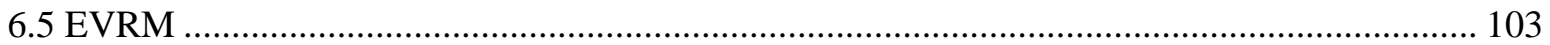

6.5.1 Relevantie voor het recht op zorg voor de gezondheid ................................................... 103

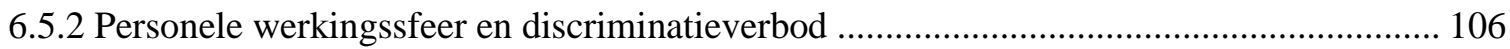

6.5.3 Overige instrumenten Raad van Europa ............................................................................. 107

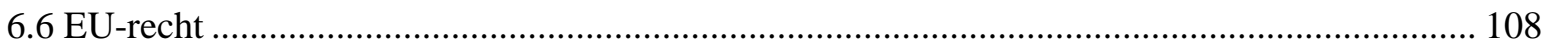

6.6.1 Recht op zorg voor de gezondheid en volksgezondheid .................................................. 108

6.6.2 Personele werkingssfeer en discriminatieverbod ................................................................. 109

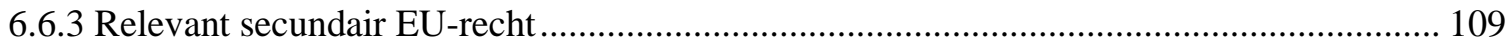

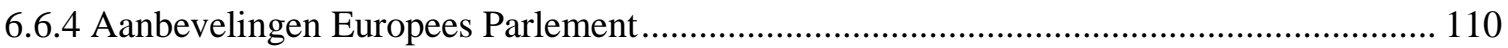

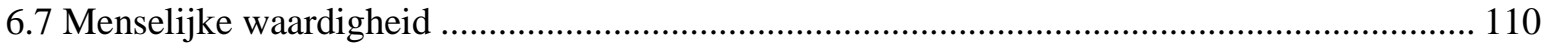

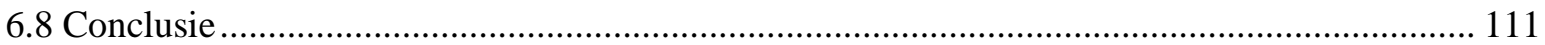

Hoofdstuk 7 Uitzetting van de (ernstig) zieke vreemdeling ...................................................... 113

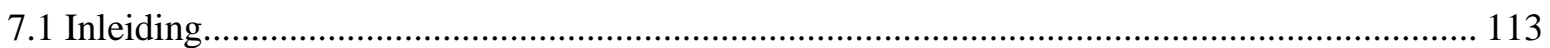

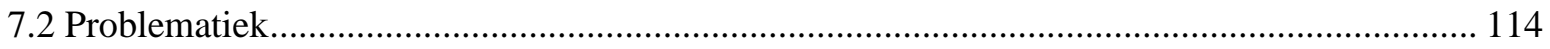

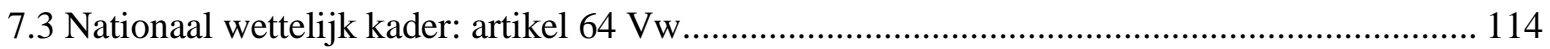

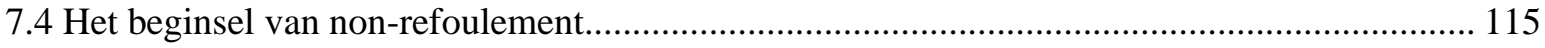

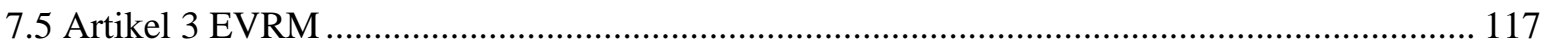

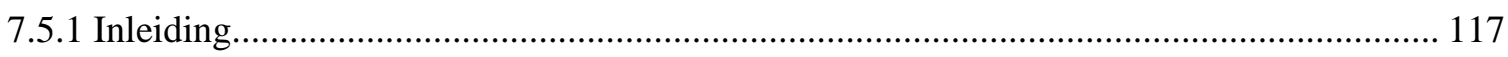

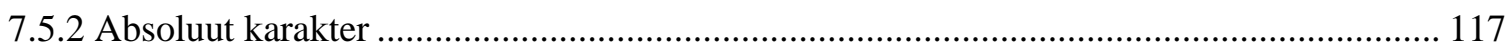

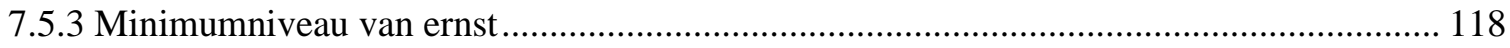

7.5.4 De drie elementen van artikel 3 EVRM: onderscheid ................................................... 118

7.5.5 De drie elementen van artikel 3 EVRM in medische gevallen.......................................... 119

7.6 Jurisprudentie EHRM over uitzetting van (dood)zieke vreemdelingen ................................... 120

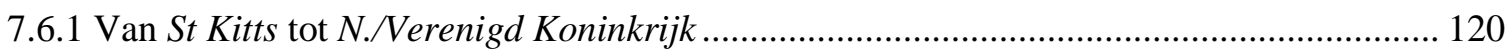

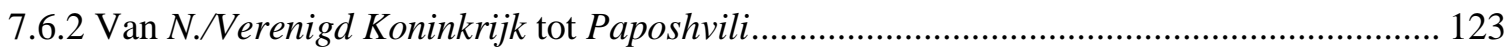

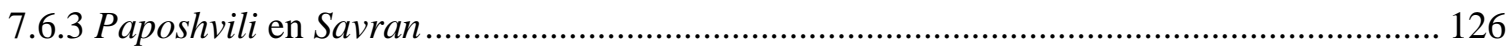

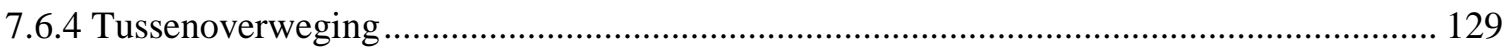

7.7 Jurisprudentie HvJ EU over uitzetting van (ernstig) zieke vreemdelingen .............................. 130

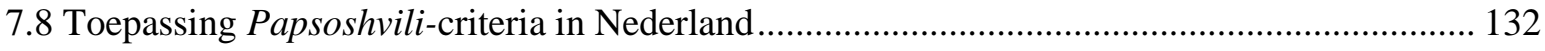

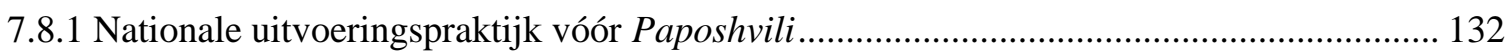

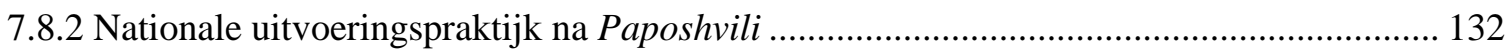

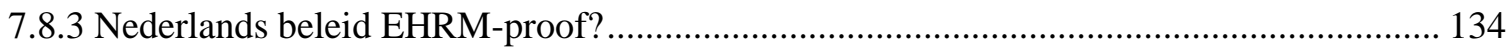

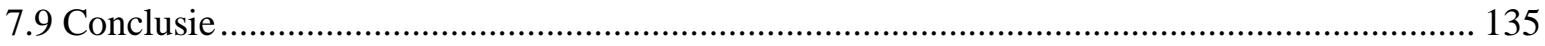


Hoofdstuk 8 Juridische houdbaarheid van het koppelingsbeginsel in relatie tot artikel 122a Zvw .... 137

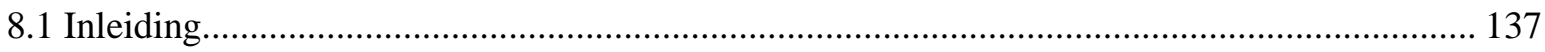

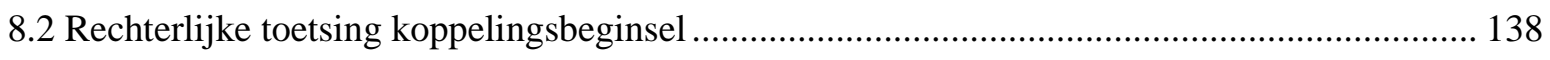

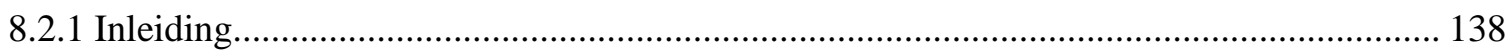

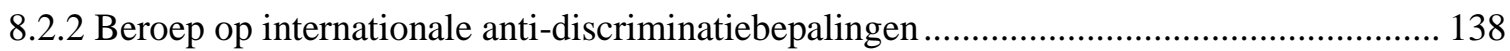

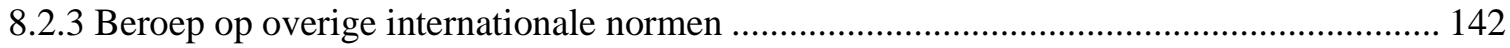

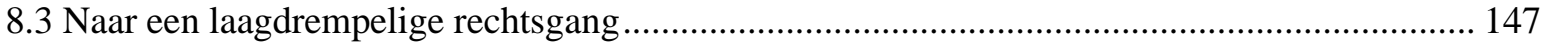

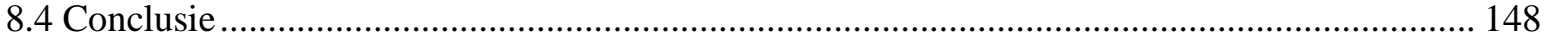

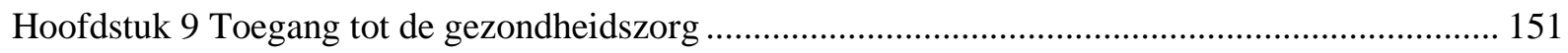

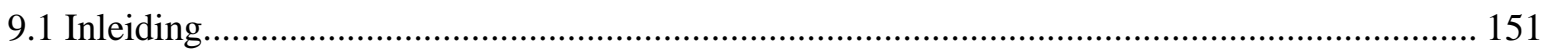

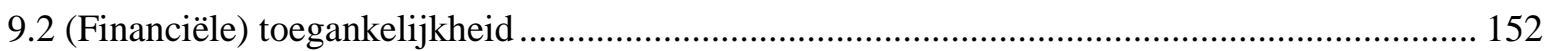

9.3 De werking van de financieringsregeling in de praktijk........................................................ 152

9.3.1 Vóór invoering artikel 122a Zvw (de Regeling Stichting Koppeling) .............................. 152

9.3.2 Na invoering artikel 122a Zvw (de bijdrageregeling) ...................................................... 153

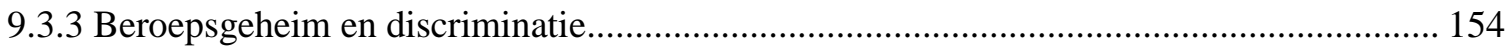

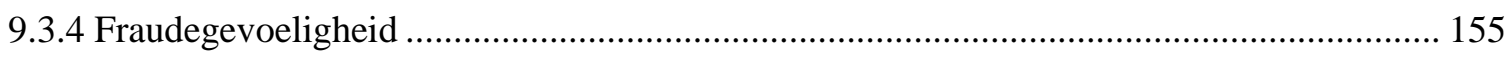

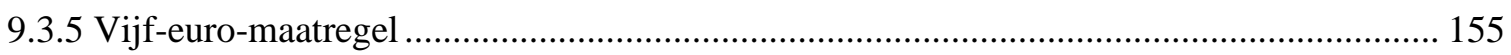

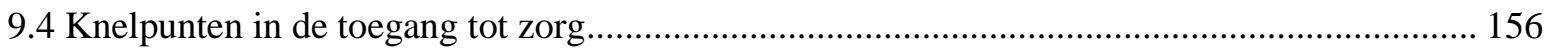

9.4.1 Aanbevelingen Nationale ombudsman en 'Zorgeloos op straat' ....................................... 156

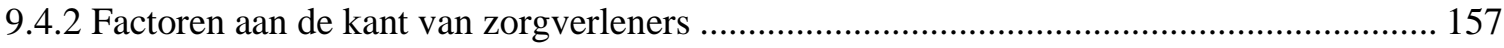

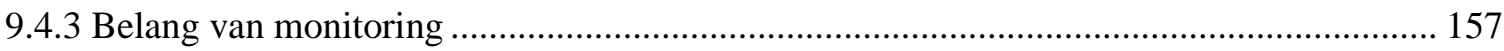

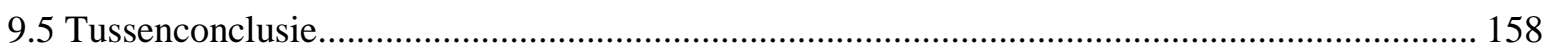

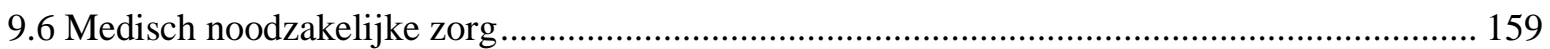

9.6.1 Automatische koppeling met basispakket Zvw .............................................................. 159

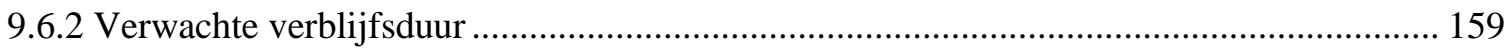

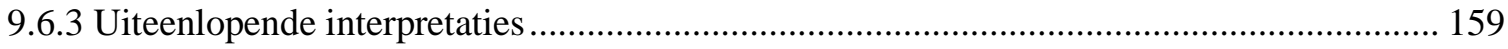

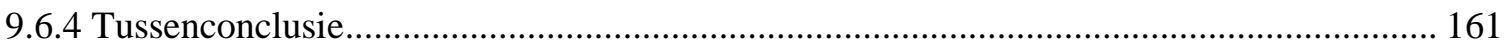

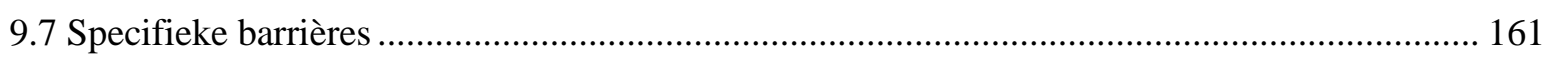

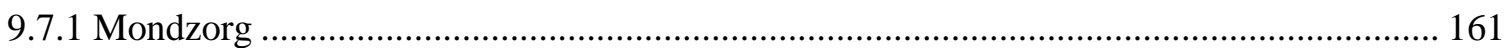

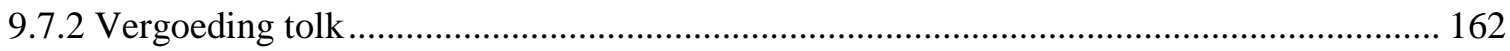

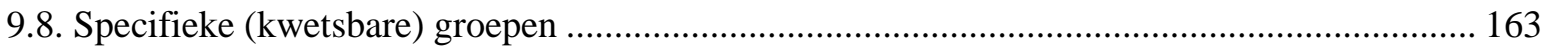

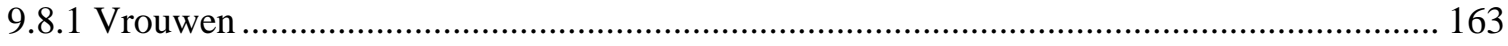

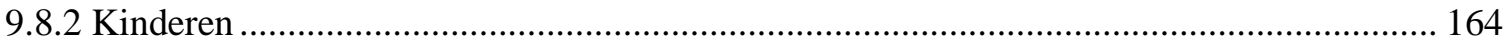

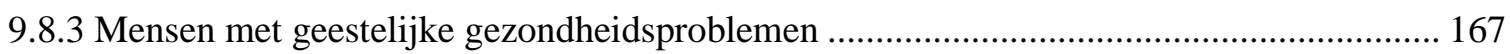

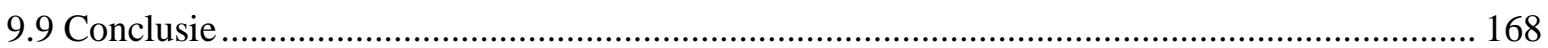

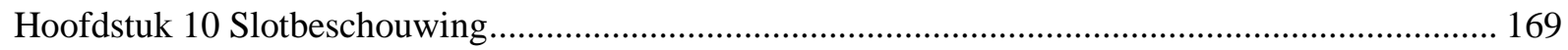

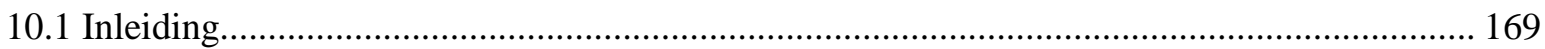




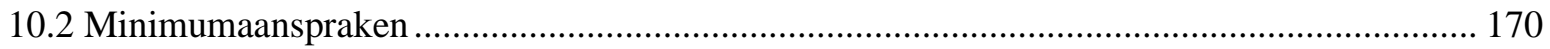

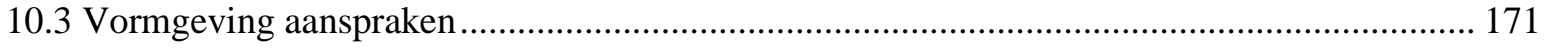

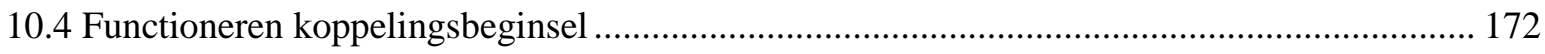

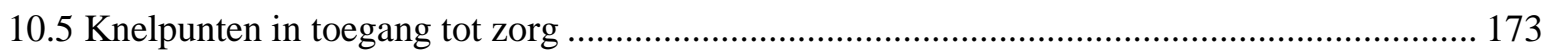

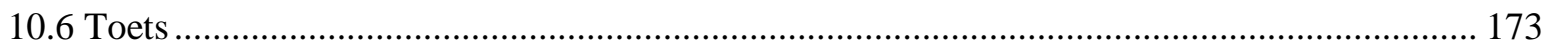

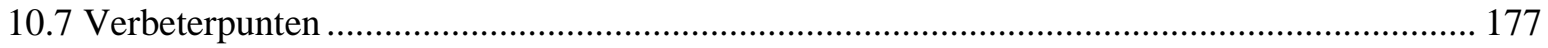

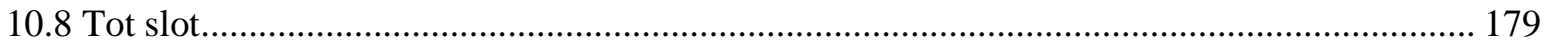

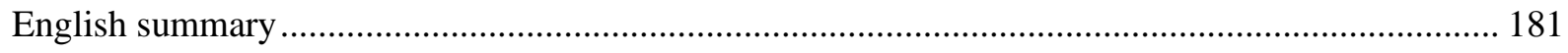

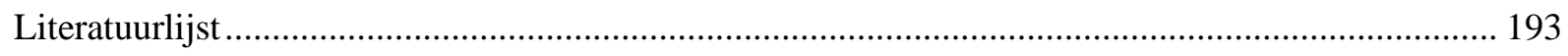

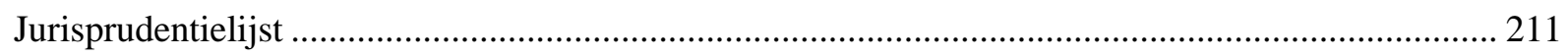

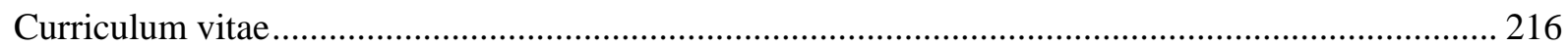




\begin{tabular}{|c|c|}
\hline AA & Ars Aequi \\
\hline Abw & Algemene bijstandswet \\
\hline ABRvS & Afdeling bestuursrechtspraak van de Raad van State \\
\hline $\mathrm{ACVZ}$ & Adviescommissie voor Vreemdelingenzaken \\
\hline AKW & Algemene Kinderbijslagwet \\
\hline $\mathrm{AMvB}$ & Algemene Maatregel van Bestuur \\
\hline Art. & Artikel \\
\hline AWBZ & Algemene Wet Bijzondere Ziektekosten \\
\hline Awir & Algemene wet inkomensafhankelijke regelingen \\
\hline Azc & Asielzoekerscentrum \\
\hline $\mathrm{Blz}$ & Besluit langdurige zorg \\
\hline BMA & Bureau Medische Advisering \\
\hline $\mathrm{BMO}$ & Breed Medisch Overleg \\
\hline BRP & Basisregistratie Personen \\
\hline CAT & Committee Against Torture \\
\hline CESCR & $\begin{array}{l}\text { Committee on Economic, Social and Cultural Rights (VN-Comité voor } \\
\text { economische, sociale en culturele rechten) }\end{array}$ \\
\hline CI & Cochleair implantaat \\
\hline $\mathrm{CIZ}$ & Centrum Indicatiestelling Zorg \\
\hline $\mathrm{COA}$ & Centraal Orgaan opvang asielzoekers \\
\hline $\mathrm{CRC}$ & Committee on the Rights of the Child \\
\hline CRvB & Centrale Raad van Beroep \\
\hline CTG & Centraal Tuchtcollege voor de Gezondheidszorg \\
\hline $\mathrm{CVZ}$ & College voor Zorgverzekeringen \\
\hline DRi II & Definitierichtlijn \\
\hline DT\&V & Dienst Terugkeer en Vertrek \\
\hline ECSR & Europees Comité voor Sociale Rechten \\
\hline EHRM & Europese Hof voor de Rechten van de Mens \\
\hline EJHL & European Journal of Health Law \\
\hline ESH (herzien) & Europees Sociaal Handvest (herzien) \\
\hline EU & Europese Unie \\
\hline EVRM & Europees Verdrag voor de Rechten van de Mens \\
\hline FRA & European Union Agency for Fundamental Rights \\
\hline GEAS & Gemeenschappelijk Europees Asielsysteem \\
\hline GGZ & Geestelijke Gezondheidszorg \\
\hline GJ & Gezondheidszorg Jurisprudentie \\
\hline Gw & Grondwet \\
\hline Handvest & Handvest van de grondrechten van de Europese Unie \\
\hline HR & Hoge Raad \\
\hline HRC & Human Rights Committee (VN Mensenrechten Comité) \\
\hline HvJ EU & Hof van Justitie van de Europese Unie \\
\hline IGJ & Inspectie Gezondheidszorg en Jeugd \\
\hline IGZ & Inspectie voor de Gezondheidszorg \\
\hline IND & Immigratie- en Naturalisatiedienst \\
\hline
\end{tabular}




\begin{tabular}{|c|c|}
\hline IJenV & Inspectie Justitie en Veiligheid \\
\hline IND & Immigratie- en Naturalisatiedienst \\
\hline IOM & Internationale Organisatie voor Migratie \\
\hline IVBRP & Internationaal Verdrag inzake burgerrechten en politieke rechten \\
\hline IVESCR & $\begin{array}{l}\text { Internationaal Verdrag inzake Economische, Sociale en Culturele } \\
\text { Rechten }\end{array}$ \\
\hline Ivf & In vitro fertilisatie \\
\hline IVRK & Internationaal Verdrag inzake de Rechten van het Kind \\
\hline JenV & Justitie en Veiligheid \\
\hline KNMG & $\begin{array}{l}\text { Koninklijke Nederlandsche Maatschappij tot bevordering der } \\
\text { Geneeskunst }\end{array}$ \\
\hline KNMT & $\begin{array}{l}\text { Koninklijke Nederlandse Maatschappij tot bevordering der } \\
\text { Tandheelkunde }\end{array}$ \\
\hline LHV & Landelijke Huisartsen Vereniging \\
\hline LVV & Landelijke Vreemdelingenvoorzieningen \\
\hline JenV & Ministerie van Justitie en Veiligheid \\
\hline MC & Medisch Contact \\
\hline MvT & Memorie van toelichting \\
\hline NJB & Nederlands Juristenblad \\
\hline NJCM & Nederlands Juristen Comité voor de Mensenrechten \\
\hline NRV & Nationale Raad voor de Volksgezondheid \\
\hline NTvG & Nederlands Tijdschrift voor Geneeskunde \\
\hline NVK & Nederlandse Vereniging voor Kindergeneeskunde \\
\hline ORi II & Opvangrichtlijn \\
\hline $\mathrm{NZa}$ & Nederlandse zorgautoriteit \\
\hline PACE & Parlementary Assembly of the Council of Europe \\
\hline Par. & Paragraaf/Paragrafen \\
\hline $\mathrm{PbEU}$ & Publicatieblad van de Europese Unie \\
\hline PBW & Penitentiaire Beginselenwet \\
\hline PGA & Publieke Gezondheidszorg Asielzoekers \\
\hline $\mathrm{Pgb}$ & Persoonsgebonden budget \\
\hline PICUM & Platform for International Cooperation on Undocumented Migrants \\
\hline PILPGL & Public International Law \& Policy Group \\
\hline PRi II & Procedurerichtlijn \\
\hline PTSS & Post Traumatische Stress Stoornis \\
\hline $\mathrm{Rb}$. & Rechtbank \\
\hline RFB & Reglement financiële bijdragen Stichting Koppeling \\
\hline $\mathrm{Rlz}$ & Regeling langdurige zorg \\
\hline RMA & Regeling Medisch zorg Asielzoekers \\
\hline Rva 2005 & $\begin{array}{l}\text { Regeling verstrekkingen asielzoekers en andere categorieën } \\
\text { vreemdelingen } 2005\end{array}$ \\
\hline $\mathrm{Rvb}$ & Regeling verstrekkingen bepaalde categorieën vreemdelingen \\
\hline $\operatorname{RvS}$ & Raad van State \\
\hline Rwn & Rijkswet op het Nederlanderschap \\
\hline
\end{tabular}




\begin{tabular}{|c|c|}
\hline RZA & Regeling Zorg Asielzoekers \\
\hline SDGs & Sustainable development goals \\
\hline SES & Sociaal-economische status \\
\hline SGC & Schengengrenscode \\
\hline $\mathrm{Sr}$ & Wetboek van Strafrecht \\
\hline Stb & Staatsblad \\
\hline Stcr & Staatscourant \\
\hline Tbc & Tuberculose \\
\hline $\mathrm{T} \& \mathrm{C}$ & Tekst \& Commentaar \\
\hline TGE & Tijdschrift voor Gezondheidszorg en Ethiek \\
\hline TNO-PG & TNO-Preventie en Gezondheid \\
\hline $\mathrm{TRi}$ & Terugkeerrichtlijn \\
\hline TvGR & Tijdschrift voor Gezondheidsrecht \\
\hline UHC & Universal Health Coverage \\
\hline UMCG & Universitair Medisch Centrum Groningen \\
\hline UVRM & Universele Verklaring voor de Rechten van de Mens \\
\hline $\mathrm{Vb}$ & Vreemdelingenbesluit \\
\hline VBL & Vrijheidsbeperkende locatie \\
\hline $\mathrm{VN}$ & Verenigde Naties \\
\hline $\mathrm{V} \& \mathrm{~W}$ & Vereniging voor Volksgezondheid en Wetenschap \\
\hline Vw & Vreemdelingenwet 2000 \\
\hline VWEU & Verdrag betreffende de werking van de EU \\
\hline VWS & Ministerie van Volksgezondheid, Welzijn en Sport \\
\hline WBB & Wet Bijzondere Bijstand \\
\hline Wet BIG & Wet op de beroepen in de individuele gezondheidszorg \\
\hline Wet Bopz & Wet bijzondere opnemingen in psychiatrische ziekenhuizen \\
\hline Wgbo & Wet op de geneeskundige behandelingsovereenkomst \\
\hline WHO & Wereldgezondheidsorganisatie \\
\hline Wlz & Wet langdurige zorg \\
\hline Wmg & Wet marktordening gezondheidszorg \\
\hline Wmo & Wet maatschappelijke ondersteuning \\
\hline WODC & Wetenschappelijk Onderzoek- en Documentatiecentrum \\
\hline Wpg & Wet publieke gezondheid \\
\hline Wtg & Wet tarieven gezondheidszorg \\
\hline Wtz & Wet op de toegang tot ziektekostenverzekeringen \\
\hline WVC & Ministerie van Welzijn, Volksgezondheid en Cultuur \\
\hline WWB & Wet werk en bijstand \\
\hline Wzd & Wet zorg en dwang \\
\hline Zfw & Ziekenfondswet \\
\hline $\mathrm{ZiNL}$ & Zorginstituut Nederland \\
\hline Zvw & Zorgverzekeringswet \\
\hline
\end{tabular}




\title{
Hoofdstuk 1 Inleiding
}

\author{
Een vrouw verblijft onrechtmatig in Nederland. Zij \\ lijdt aan darmkanker in de terminale fase en heeft \\ niet lang meer te leven. Zij is dakloos en \\ onverzekerd. In haar laatste levensfase wil zij het \\ liefst in een hospice verblijven om daar rustig te \\ kunnen sterven. Zij heeft echter geen geld om dit \\ zelf te betalen.
}

\subsection{Aanleiding}

Nederland kent naar schatting enkele tienduizenden vreemdelingen die hier onrechtmatig verblijven, met of zonder asielverleden. ${ }^{1}$ Dit zijn personen zonder geldige verblijfsvergunning. Deze mensen dienen volgens het terugkeerbeleid Nederland te verlaten, maar zijn om uiteenlopende redenen hier gebleven. Omdat zij niet (meer) in aanmerking komen voor opvang van overheidswege, komen zij dikwijls op straat te staan. Velen van hen hebben gezondheidsproblemen, zowel lichamelijk als psychisch.

Bij het inroepen van medische zorg hebben deze vreemdelingen te maken met hoge drempels. De eerste drempel is een financiële: vanwege hun niet-rechtmatige status kunnen zij zich niet verzekeren tegen ziektekosten. Zij dienen de kosten van medische zorg dan ook in eerste instantie zelf te betalen. ${ }^{2}$ Daarnaast durven zij niet altijd een beroep te doen op de gezondheidszorg uit angst te worden opgepakt. Bovendien komt het nogal eens voor dat medisch noodzakelijke zorg aan deze vreemdelingen wordt onthouden. Een voorbeeld betreft de weigering van meerdere huisartsen om een ongedocumenteerd jongetje ( 8 jaar) met een arm uit de kom te helpen. ${ }^{3}$ Het onthouden van zorg kan te maken hebben met het feit dat niet alle zorgverleners bekend zijn met de mogelijkheid om kosten van verleende medisch noodzakelijke zorg vergoed te krijgen of met koudwatervrees om een ongedocumenteerde migrant zorg te verlenen. ${ }^{4}$ Het onthouden van zorg kan leiden tot ernstige gezondheidsschade en - in het ernstigste geval - onnodige sterfte.

Extra kwetsbaar zijn (zwangere) vrouwen, kinderen, chronisch zieken, (dementerende) ouderen en mensen met geestelijke problemen. De stigmatisering van de groep ongedocumenteerde vreemdelingen met psychiatrische problematiek is actueel. ${ }^{5}$ Ook de

\footnotetext{
${ }^{1}$ De laatste schatting van het Wetenschappelijk Onderzoek- en Documentatiecentrum (WODC) ging over het aantal mensen zonder geldige verblijfsvergunning in 2012-2013. Dat werd geschat tussen 22.881 tot 48.179 personen, Van der Heijden e.a. 2015. Recentere schattingen zijn niet voorhanden. Wel is er een vooronderzoek naar data en methoden voor een nieuwe schatting verricht, Snippe \& Mennes 2018.

${ }^{2}$ Zo valt het verblijf in een hospice onder palliatieve zorg. Dit verblijf wordt vergoed vanuit de basisverzekering van de Zorgverzekeringwet of vanuit de Wet langdurige zorg (bij een Wlz-indicatie).

${ }^{3}$ Voogt \& Mensinga, Vakblad Sociaal Werk 2019, afl. 6, p. 23-25.

${ }^{4}$ Pharos 2010, p. 20, Toonders e.a., MC 2020, afl. 10, p. 24-28.

${ }^{5}$ Laconi, De Stentor 24 november 2019.
} 
informatievoorziening over medische zorg voor deze groep mensen schiet te kort. Zo blijven veel ongedocumenteerden bijvoorbeeld verstoken van informatie over het corona-virus, onder andere door taalbarrières. ${ }^{6}$ Ongedocumenteerden behoren tot één van de meest kwetsbare groepen waar het gaat om preventie tegen het coronavirus en andere besmettelijke ziektes. ${ }^{7}$

De (feitelijke en financiële) toegang tot gezondheidszorg voor vreemdelingen zonder rechtmatig verblijf staat dus onder druk. Zonder financiële tegemoetkoming wordt zorg duur en wordt het recht op zorg voor de gezondheid voor onrechtmatig verblijvende vreemdelingen - doorgaans zonder inkomen - al snel illusoir. Er is op deze wijze sprake van een kloof tussen de universele werking van het individuele recht op zorg voor de gezondheid en het genot daarvan in de praktijk. ${ }^{8}$ Dit roept gezondheidsrechtelijke vragen op. Een fundamentele bespreking van dit onderwerp in de gezondheidsrechtelijke literatuur ontbreekt tot dusver. ${ }^{9}$ Dit proefschrift beoogt in deze lacune te voorzien. Het feit dat het gaat om een kwetsbare groep mensen met specifieke gezondheidsproblemen die leven in de marges van de samenleving rechtvaardigt een studie naar de vraag of deze groep vanuit gezondheidsrechtelijk perspectief voldoende wordt beschermd.

\subsection{Achtergrond}

Het internationale recht op zorg voor de gezondheid geldt volgens het universaliteitsprincipe van de mensenrechten voor een ieder, ongeacht verblijfsstatus. Uit dit recht vloeien specifieke verplichtingen voor de staat voort, waaronder het nemen van maatregelen om gelijke toegang tot gezondheidszorg te verzekeren.

Van oudsher stellen staten aanspraken op sociale voorzieningen afhankelijk van nationaliteit en/of verblijfsstatus, vaak om vreemdelingrechtelijke redenen (voorkómen van aanzuigende werking) of ter bescherming van het stelsel de sociale zekerheid (wie niet bijdraagt, mag ook niet profiteren). Indien de staat juridisch en beleidsmatig onderscheid maakt op basis van nationaliteit en/of verblijfsstatus, vergroot dat de kans dat het recht op zorg voor de gezondheid onder spanning komt te staan.

Nederland heeft in 1998 in het kader van stringent vreemdelingenbeleid de Koppelingswet ingevoerd, die de aanspraak op collectieve voorzieningen koppelt aan het

\footnotetext{
${ }^{6}$ Pilon, OneWorld 30 maart 2020.

${ }^{7}$ PICUM, Statement on COVID-19 and undocumented migrants - March 2020, picum.org (laatst geraadpleegd 19 juni 2020).

${ }^{8}$ Deze kloof is overigens niet exclusief voor het internationale recht op gezondheidszorg, ook voor het genot van andere rechten is dit het geval, zie onder meer Office of the United Nations High Commissioner for Human Rights, 'The Rights of Non-citizens', New York and Geneva, 2006. Literatuur over de (sociale) rechten van irreguliere migranten: Cholewinski 2005, Weissbrodt \& Meili, Refugee Survey Quaterly 2010/4, p. 34-58, Carens, Ethics \& International Affairs 2008/2, p. 163-186, Dupper 2010, International Journal of Social Security and Workers Compensation, 2010/2, p. 61-77, Dupper 2011, International Journal of Social Security and Workers Compensation, 2011/1, p. 55-75.

${ }^{9}$ Dit laat onverlet dat deze problematiek door verschillende gezondheidsrechtelijke auteurs aan de orde is gesteld, zie met name Gevers, TvGR 1996/3, p. 121, Hendriks, Migrantenrecht 1996/3, p. 51-56, Toebes, Migrantenrecht 1996/3, p. 197-199, De Groot, TvGR 1997/1, p. 2-9, Vermaat, TvGR 2003/1, p. 3-8, Den Exter, TGE 2004/3, p. 79-82, Sijmons \& Derckx, NJB 2010/27, p. 1398-1456, Hendriks \& Toebes, NJB 2016/19, p. 1347-1352, Derckx, TvGR 2017/2, p. 121-134. Rechtssociologisch onderzoek naar de uitsluiting van vreemdelingen van voorzieningen werd verricht door Pluymen, Pluymen 2008.
} 
verblijfsrecht van de vreemdeling (het zogenoemde koppelingsbeginsel). ${ }^{10}$ Als gevolg van deze wet vallen onrechtmatig verblijvende vreemdelingen buiten de reikwijdte van de Zorgverzekeringswet (Zvw) en zijn zij uitgesloten van alle aanspraken op basis van de Wet langdurige zorg (Wlz) en de Wet maatschappelijke ondersteuning (Wmo). Met het uitsluiten van sociale wetgeving heeft het vreemdelingenrecht het primaat over de rechtspositie van de onrechtmatig verblijvende vreemdeling: deze heeft volgens de wet geen gereguleerde status en dient het land te verlaten. Ondertussen kan de overheid niet om het feit heen dat degene die 'rechteloos' in een land verblijft, toch aanspraak maakt op basale rechten vanwege het feit dat deze persoon op diens grondgebied verblijft. De rechteloosheid kan niet worden volgehouden waar het gaat om de mensenrechten die universeel zijn. Er zijn daarom uitzonderingen op het koppelingsbeginsel, waaronder medisch noodzakelijke zorg.

Deze uitzondering is vormgegeven via de (huidige) financieringsregeling ex artikel 122a Zvw, op grond waarvan zorgverleners onder bepaalde voorwaarden vergoeding kunnen ontvangen voor verleende medisch noodzakelijke zorg aan bepaalde groepen vreemdelingen, onder wie vreemdelingen die geen rechtmatig verblijf hebben (de Regeling onverzekerbare vreemdelinge ${ }^{11}$ ). Kritiek op deze constructie is dat de overheid het aan de zorgaanbieder heeft overgelaten om de omvang van het recht op zorg van de vreemdeling te bepalen. ${ }^{12}$ Daarmee is een doel van het vreemdelingenbeleid (uitsluiting van sociale voorzieningen) een probleem geworden van de zorgverlener, die immers geconfronteerd wordt met dilemma's over de reikwijdte van de verstrekking van de medische zorg aan deze groep mensen.

In dit proefschrift staat dit systeem (uitsluiting van de Zvw en de Wlz en financiering van medische zorg via een bijdrageregeling) centraal. De vraag is of (de uitvoering van) dit systeem wel voldoet aan grond- en mensenrechtelijke principes. Deze vraag is relevant, omdat vast staat dat er altijd onrechtmatig verblijvende vreemdelingen in Nederland zullen zijn, ongeacht beleid en regelgeving. ${ }^{13}$ De inherente spanning tussen de doelen van het vreemdelingenrecht (vertrekplicht en uitzetting) en het gezondheidsrecht (recht op zorg voor de gezondheid) is van blijvende aard. Dit onderzoek kan een opstap te bieden voor verdere discussie en keuzes met betrekking tot (de toegang tot) de gezondheidszorg van deze groep mensen in de toekomst.

\subsection{Doel en probleemstelling}

Dit proefschrift kent als centraal thema het spanningsveld tussen het recht op gezondheid van de vreemdeling die onrechtmatig in Nederland verblijft en de uitsluiting van de aanspraken uit hoofde van de zorgverzekeringen van deze groep. Vanuit het internationale humanitaire perspectief van het recht op zorg voor de gezondheid onderzoek ik hoe de overheidsverantwoordelijkheid voor medische zorg aan onrechtmatig verblijvende vreemdelingen in

\footnotetext{
${ }^{10}$ Wet van 26 maart 1998 tot wijziging van de Vreemdelingenwet en enige andere wetten teneinde de aanspraak van vreemdelingen jegens bestuursorganen op verstrekkingen, voorzieningen, uitkeringen, ontheffingen en vergunningen te koppelen aan het rechtmatig verblijf van de vreemdeling in Nederland, Stb. 1998, 203 en 204.

${ }^{11}$ De Regeling onverzekerbare vreemdelingen wordt uitgevoerd door het CAK en is te vinden op hetcak.nl.

${ }^{12}$ Sijmons \& Derckx, NJB 2010/27, p. 1398-1456, Hendriks \& Toebes, NJB 2016/19, p. 1347-1352, Leenen e.a. 2017 , p. 548.

${ }^{13}$ Rapport Commissie 'Langdurig verblijvende vreemdelingen zonder verblijfsrecht' 2019, p. 6. 44 procent van de afgewezen asielzoekers keert vanuit Nederland terug naar het land van herkomst.
} 
Nederland is vormgegeven. Getoetst wordt in hoeverre de kern van het gekozen systeem ('medisch noodzakelijke zorg') in overeenstemming is met gepositiveerde grondrechten, mensenrechten en gezondheidsrechtelijke principes.

Het primaire doel van het onderzoek is het verschaffen van meer helderheid over het recht op zorg voor de gezondheid van de onrechtmatig verblijvende vreemdeling. Het gaat hier om het analyseren van de minimumaanspraken van de vreemdeling zonder rechtmatig verblijf op zorg en de verantwoordelijkheid van de overheid en zorgverleners jegens deze groep. Secundair beoogt het onderzoek bij te dragen aan een versterking van de rechtspositie van deze kwetsbare groep mensen, zodat hun gezondheid kan worden bevorderd. De volgende onderzoeksvraag staat centraal:

Op welke wijze is het recht op zorg voor de gezondheid van vreemdelingen die onrechtmatig in Nederland verblijven gewaarborgd tegen de achtergrond van de Koppelingswet en het beleid op basis van deze wet? Welke verbeterpunten kunnen ten aanzien van deze waarborging worden geïdentificeerd?

Deze onderzoeksvraag zal worden beantwoord aan de hand van een zestal deelvragen.

De contouren van het recht op zorg voor de gezondheid worden mede bepaald door bovennationale normen. Voor de analyse van de gezondheidsrechtelijke rechtspositie van de onrechtmatig verblijvende vreemdeling is dit kader dan ook van belang. Dit brengt ons tot de eerste deelvraag:

(1) Welke aanspraken op gezondheidszorg hebben vreemdelingen die onrechtmatig in Nederland verblijven ten principale?

Deze deelvraag ziet op de vraag welke (minimum) aanspraken op medische zorg de onrechtmatig verblijvende vreemdeling kan ontlenen aan het internationaal, Europees en nationaal recht. Hebben deze mensen bijvoorbeeld het recht om deel te nemen aan preventieve zorg? Dient de staat hen bijvoorbeeld een vaccin voor het coronavirus (COVID-19) aan te bieden? Voor de kerninhoud van het recht op zorg is zowel het internationaal gezondheidsrechtelijke kader als het nationaal grondwettelijk kader van belang. Het recht op gezondheid ${ }^{14}$ ligt verankerd in de Nederlandse Grondwet $(\mathrm{Gw})$ en in diverse internationale verdragen waarbij Nederland partij is, zoals het Internationaal Verdrag inzake Economische, Sociale en Culturele Rechten (IVESCR), het Internationale Verdrag inzake de Rechten van het Kind (IVRK) en het Europees Sociaal Handvest (herzien) (ESH (herzien)). Voor het antwoord op de vraag of vreemdelingen zonder rechtmatig verblijf zich op deze internationale standaarden kunnen beroepen, is de personele reikwijdte van de genoemde verdragen van belang. Het recht op zorg voor de gezondheid krijgt daarnaast vorm via verplichtingen die voortvloeien uit de bescherming van klassieke grondrechten die besloten liggen in (onder meer) het Internationaal Verdrag inzake burgerrechten en politieke rechten (IVBPR) en het Europees Verdrag voor de Rechten van de Mens (EVRM). Met name van belang zijn het recht op leven, het verbod op foltering en onmenselijke behandeling, het recht op privéleven en het verbod op discriminatie. Bij uitzetting van ernstige zieke vreemdelingen naar het land van herkomst speelt

\footnotetext{
${ }^{14}$ Internationaal is 'recht op gezondheid' de gebezigde terminologie, zie hoofdstuk 6.
} 
artikel 3 EVRM (verbod op foltering en onmenselijke behandeling) een belangrijke rol. Daarnaast bieden richtlijnen van de Europese Unie (EU) minimumnormen voor medische bijstand en geeft artikel 1 Handvest van de grondrechten van de EU (Handvest) ${ }^{15}$ extra bescherming aan mensen zonder rechtmatig verblijf.

De tweede deelvraag ziet op de nationale uitvoering van deze aanspraken:

(2) Hoe zijn deze aanspraken (als die er zijn) concreet vormgegeven in het Nederlandse systeem (uitsluiten van zorgverzekeringen en financiering van medisch noodzakelijke zorg), zowel tijdens het verblijf in Nederland als in de fase van uitzetting naar het land van herkomst?

Bij de beantwoording van deze deelvraag zal ik onderzoeken op welke wijze de Nederlandse overheid vorm heeft gegeven aan het recht op medisch noodzakelijke zorg van onrechtmatig verblijvende vreemdelingen in wet- en regelgeving. Op welke medische zorg heeft de vreemdeling aanspraak (als die aanspraak er is) en hoe wordt die zorg gefinancierd? De Koppelingswet en de aan deze wet ten grondslag liggende regelgeving en beleid staan daarbij centraal. Er vindt een analyse plaats van keuzes en uitgangspunten van de overheid ten aanzien van de waarborging van de toegankelijkheid van de medische zorg voor onrechtmatig verblijvende vreemdelingen, ook na een geslaagd beroep op artikel 3 EVRM in het kader van uitzetting.

De derde deelvraag ziet op de juridische gevolgen van de Koppelingswet en luidt als volgt:

(3) Hoe functioneert het koppelingsbeginsel in de praktijk, specifiek met betrekking tot aanspraken op medische zorg?

Ter beantwoording van deze deelvraag wordt primair jurisprudentie over de rechtmatigheid van het koppelingsbeginsel in het licht van internationale verdragen geanalyseerd. Welke ruimte heeft de overheid vanuit internationaal en Europees recht om bij aanspraken op gezondheidszorg onderscheid te maken op grond van verblijfsstatus? Secundair vindt een analyse plaats van jurisprudentie waarin een beroep werd gedaan op doorbreking van het koppelingsbeginsel ten behoeve van aanspraken op sociale voorzieningen, met name medische zorg. Vervolgens toets ik in hoeverre het systeem houdbaar is voor individuele gevallen, waarbij ik doel op de vraag in hoeverre er voldoende juridisch vangnet bestaat voor individuele (schrijnende) gevallen.

Zoals hierboven al werd vermeld, is sprake van specifieke barrières bij het inroepen van medische zorg. In de sociaalwetenschappelijke literatuur wordt onderscheid gemaakt tussen informele drempels en formele drempels die ongedocumenteerden ervaren bij het inroepen van medische zorg. ${ }^{16}$ Informele drempels met betrekking tot de toegang tot zorg zien enerzijds op factoren die te maken hebben met de ongedocumenteerde (denk aan taalbarrières) en anderzijds de zorgaanbieders (denk aan onbekendheid met regelingen). Formele drempels hebben te maken met het gezondheidsbeleid en de organisatie van de zorg (het systeem). Het gaat hierbij

\footnotetext{
${ }^{15}$ Handvest van de Grondrechten van de Europese Unie, 2012/C 326/02.

${ }^{16}$ Vgl. Rechel e.a. 2011, p. 71-72, De Vito e.a. 2015.
} 
om toegankelijkheid, betaling, interpretatie van het begrip 'medisch noodzakelijke zorg' en de invulling van de hulpverleningsplicht. In dit proefschrift staan de formele drempels centraal. De informele drempels zijn meer praktisch van aard en daarom niet onderworpen aan juridisch onderzoek. Dat neemt niet weg dat zij illustreren dat formele drempels niet op zichzelf staan maar kunnen worden versterkt door de informele drempels. Zij zijn onlosmakelijk met elkaar verbonden. Vandaar dat het proefschrift tevens aandacht besteedt aan de informele drempels. Dit brengt me tot de vierde deelvraag:

(4) Welke knelpunten doen zich voor met betrekking tot (toegang tot) de zorgverlening aan ongedocumenteerden (formele drempels), met name kwetsbare groepen?

Extra aandacht besteed ik daarbij aan vrouwen, kinderen met een gezondheidsprobleem (voor wie geen specifiek toegesneden regeling bestaat) en mensen met geestelijke gezondheidsproblemen. Het in kaart brengen van deze drempels vormt een opstap voor de vijfde deelvraag:

(5) Hoe verhoudt het Nederlandse systeem zich tot de gepositiveerde grond-en mensenrechten en gezondheidsrechtelijke principes?

Bij de beantwoording van deze deelvraag wordt getoetst hoe het systeem zich verhoudt tot het recht op zorg voor de gezondheid van de onrechtmatig verblijvende vreemdeling, overige mensenrechten en gezondheidsrechtelijke principes, zoals beschreven onder deelvraag 1 . Is er sprake van een regeling die aan humanitaire en internationale normen voldoet, zoals de Koppelingswet beoogde? Is er geen sprake van een te hoge drempel? Worden hulpverleners naar behoren gefinancierd? Zijn er duidelijke criteria voor de vraag welke zorg verleend moet worden?

De zesde en laatste deelvraag gaat in op de vraag:

(6) Welke verbeterpunten zijn er aan te wijzen als het gaat om het in Nederland gevoerde beleid in het licht van de Koppelingswet en het recht op zorg voor de gezondheid van de onrechtmatig verblijvende vreemdeling?

Bij de beantwoording van deze deelvraag worden verbeterpunten aangedragen op basis van de bevindingen uit de eerdere deelvragen.

\subsection{Gezondheidsrechtelijke context}

1.4.1 Omschrijving en doel van het gezondheidsrecht

Het onderwerp van dit proefschrift is verankerd in het gezondheidsrecht, meer specifiek in het leerstuk recht op zorg voor de gezondheid. Er wordt bij het onderzoek uitgegaan van de volgende uitgangspunten en vooronderstellingen van dit vakgebied respectievelijk leerstuk. ${ }^{17}$

Het gezondheidsrecht kent van oudsher twee kernonderwerpen: de rechten van de

\footnotetext{
${ }^{17}$ De inhoudelijke verankering van het onderzoek biedt een afgrenzing en beschrijving van theorieën, inzichten en concepten die in het onderzoek wel gebruikt worden, maar verder niet betwist worden, Thijssen 2009, p. 55.
} 
patiënt en de erkenning van het recht op zorg voor de gezondheid. ${ }^{18}$ Het doel van het gezondheidsrecht is het beschermen van mensen in de gezondheidszorg en het creëren van evenwichtige verhoudingen in en ten aanzien van de zorg voor de gezondheid. ${ }^{19}$ Volgens Leenen e.a. gaat het om goede en humane zorg en rechtvaardige verdeling van de beschikbare mogelijkheden. ${ }^{20}$ Het gezondheidsrecht is een horizontale discipline. De welbekende omschrijving van het gezondheidsrecht luidt als volgt: 'het geheel van rechtsregels dat betrekking heeft op zorg voor de gezondheid en de toepassing van overig burgerlijk, bestuurs- en strafrecht in dat verband'. ${ }^{21}$ Uitgangspunt is dat noodzakelijke zorg voor iedereen gelijkelijk beschikbaar moet zijn op basis van medische behoefte. ${ }^{22}$

Het recht op zorg voor de gezondheid van vreemdelingen met onrechtmatig verblijf is een onderwerp dat zich er goed voor leent om vanuit de eigen aard van deze discipline te worden bestudeerd.

\subsubsection{Recht op zorg voor de gezondheid}

Het recht op zorg voor de gezondheid wordt onderverdeeld in het recht op zorg voor de gezondheid en het recht op gezondheidsbescherming en gezondheidsbevordering. ${ }^{23}$ Voor beide aspecten van het recht op zorg voor de gezondheid ligt de verankering in artikel $22 \mathrm{Gw}$, op grond waarvan de overheid verplicht is om maatregelen te treffen ter bevordering van de volksgezondheid. Een ieder dient toegang te hebben tot voor de gezondheid noodzakelijke zorg die aan kwaliteitseisen voldoet. Toegankelijkheid omvat beschikbaarheid en financiële bereikbaarheid. $^{24}$

Het recht op zorg voor de gezondheid behoort tot de sociale grondrechten. Kenmerk van sociale grondrechten is dat dat de inhoud ervan in beginsel afhankelijk is van de welvaart van een land. Sociale rechten zijn lastiger af te dwingen dan klassieke grondrechten. ${ }^{25}$ In de literatuur wordt onderscheid gemaakt tussen het formele en het materiële aspect van sociale grondrechten. Het formele aspect behelst de instructienorm van de sociale grondrechten jegens de overheid. Deze instructienorm houdt in dat de overheid weliswaar de verantwoordelijkheid heeft om deze rechten te realiseren, maar genoodzaakt is dit te doen met inachtneming van de beschikbare financiële middelen en andere prioriteiten. ${ }^{26}$ De gezondheidszorg kent grenzen en de overheid dient keuzes te maken. De overheid hoeft het recht op gezondheidszorg niet zelf te effectueren, maar blijft wel eindverantwoordelijk. ${ }^{27}$ Het materiële aspect van sociale grondrechten hangt samen met de typering van Leenen van sociale grondrechten als 'participatierecht': doel van sociale rechten is dat het individu meeprofiteert van wat de

\footnotetext{
${ }^{18}$ Leenen e.a. 2017 , p. 31.

${ }^{19}$ Leenen e.a. 2017 , p. 32.

${ }^{20}$ Leenen e.a. 2017 , p. 32.

${ }^{21}$ Leenen e.a. 2017 , p. 33.

${ }^{22}$ Gevers 2010, TvGR 2010, afl. 5, p. 363-371, p. 368.

${ }^{23}$ Leenen 1997 , p. 7.

${ }^{24}$ Leenen 1997, p. 31-32.

${ }^{25}$ Leenen 2017, p. 51-52.

${ }^{26}$ Roscam Abbing 1984, p. 3, Leenen 1997, p. 7.

${ }^{27}$ Leenen 1979, p. 7.
} 
samenleving aan goederen of diensten verkrijgt, met dien verstande dat dit individu hieraan zelf actief bijdraagt. ${ }^{28}$

\subsubsection{Rechtsbeginselen}

Aan het positieve recht liggen rechtsbeginselen ten grondslag. In het gezondheidsrecht staan drie rechtsbeginselen centraal: het zelfbeschikkingsbeginsel, het beschermingsbeginsel en het gelijkheidsbeginsel. ${ }^{29}$ Rechtsbeginselen vormen de grondslag van het positieve recht en bieden richting aan de toepassing hiervan. Moeder der rechtsbeginselen is de menselijke waardigheid. Dit beginsel ligt ten grondslag aan de mensenrechten. Volgens Hendriks heeft de overheid de verplichting om ervoor zorg te dragen dat alle mensen een menswaardig leven kunnen leiden. ${ }^{30}$ Bij het zelfbeschikkingsrecht gaat het om het (niet gecodificeerde) recht van de mens om naar zijn eigen levensopvatting te leven. Het beschermingsbeginsel houdt in dat er verantwoordelijkheid wordt genomen voor de bescherming van diegenen die zorg of hulp nodig hebben. Dit hangt nauw samen met solidariteit. Het gelijkheidsbeginsel houdt gezondheidsrechtelijk in dat benadeling bij de toegang tot de gezondheidszorg en de verdeling van schaarse voorzieningen wordt voorkómen. Onder het gelijkheidsbeginsel valt ook dat eenieder aanspraak maakt op een behandeling die getuigt van gelijk respect voor ieders waardigheid. ${ }^{31}$

Het recht op zorg voor de gezondheid is een basisvoorwaarde voor het recht op leven en de uitoefening van andere individuele rechten. Het onthouden van medisch noodzakelijke zorg kan de menselijke waardigheid aantasten. Waar de wet mensen uitsluit, kan de menselijke waardigheid als ondergrens worden beschouwd voor de vraag of het onthouden van zorg of de financiering daarvan aanvaardbaar is. Het concept van menselijke waardigheid is multiinterpretabel en kan op verschillende wijzen worden ingevuld. ${ }^{32}$

Ook al is het grondrechtelijk moederbeginsel van de menselijke waardigheid niet als zodanig opgenomen in de $\mathrm{Gw}$, het zal in de toekomst aan juridische betekenis winnen gezien de codificatie ervan in het Handvest. In dit proefschrift stel ik dit beginsel centraal als gezondheidsrechtelijk beginsel.

\subsection{Methode van onderzoek}

De kern van het proefschrift is gelegen in het spanningsveld tussen enerzijds het recht op gezondheidszorg van de vreemdeling (met name de financiële toegankelijkheid) en anderzijds de ruime beleidsvrijheid die de overheid heeft op het gebied van sociale zekerheid. Onderzocht wordt in hoeverre het recht op gezondheidszorg binnen deze beleidsvrijheid (meer concreet: het régime van de Koppelingswet) gewaarborgd is. Daartoe dient de reikwijdte van deze met elkaar

\footnotetext{
${ }^{28}$ Roscam Abbing 1984, p. 3, onder verwijzing naar Leenen 1964, p. 774.

${ }^{29}$ Hendriks 2005. Sijmons hanteert een andere systematiek van rechtsbeginselen in het gezondheidsrecht, te weten het zelfbeschikkingsrecht, het solidariteitsbeginsel en de professionele autonomie, Sijmons 2008, p. 17-18. In tegenstelling tot Hendriks, beschouwt Sijmons het solidariteitsbeginsel als de eigenlijke tegenhanger van het zelfbeschikkingsbeginsel. Ten tijde van de (huidige) coronacrisis zien we het zelfbeschikkingsrecht ingeperkt door zowel het solidariteitsbeginsel als het beschermingsbeginsel. Zowel bescherming als solidariteit zijn in dit geval tegenhangers van het zelfbeschikkingsrecht.

${ }^{30}$ Hendriks 2005, p. 44.

${ }^{31}$ Hendriks 2005, p. 25.

${ }^{32}$ Vgl. Düwell 2014.
} 
botsende vrijheid en rechten nader te worden verkend. Van belang daarbij is om het systeem als zodanig (het koppelingsbeginsel en de uitzondering medisch noodzakelijke zorg) te toetsen op juridische houdbaarheid ten principale.

Het onderzoek kent een klassiek-juridische onderzoeksmethode. Voor het descriptieve en analytische deel van het onderzoek maak ik gebruik van de voor juristen aanvaarde bronnen: verdragen, wetgeving, parlementaire geschiedenis, jurisprudentie, doctrine en rechtsbeginselen. $^{33}$ Naast de juridische bronnen is gebruik gemaakt van (wetenschappelijke) rapporten van adviesorganen en internationale (non-gouvermentele) organisaties.

De te bewandelen route - die niet automatisch de volgorde van de deelvragen volgt ziet er als volgt uit. Voor een eerste verkenning van het thema is van belang om te exploreren wat de wet verstaat onder de term 'vreemdeling' en meer specifiek 'de vreemdeling zonder rechtmatig verblijf'. Daartoe wordt eerst onderzocht welke categorieën vreemdelingen er bestaan volgens de Vreemdelingenwet 2000 (Vw). Vervolgens vindt een inventarisatie plaats van de specifieke gezondheidsproblemen van migranten en de informele drempels die zij ervaren bij het inroepen van medische zorg. Bij deze verkenning worden alle categorieën vreemdelingen betrokken, omdat de onrechtmatig verblijvende vreemdeling verschillende achtergronden kan hebben. Deze analyse is met name gebaseerd op niet-juridische wetenschappelijke onderzoek en literatuur.

$\mathrm{Na}$ deze verkenning beland ik bij de behandeling van het fundament van het systeem: de Koppelingswet. In dit deel van het onderzoek zal ik systematisch beschrijven wat de achtergrond is van de Koppelingswet en op welke wijze het gekozen systeem is uitgevoerd in wet- en regelgeving en beleid (deelvraag 2). De doeleinden van deze wet en de parlementaire geschiedenis ervan worden in kaart gebracht waarbij de focus ligt op de uitwerking van het koppelingsbeginsel voor de gezondheidszorg. Doel van dit historische overzicht is om de motieven van de wetgever voor bepaalde keuzen zichtbaar te maken. Hierbij hebben rapporten van verschillende adviesorganen een rol gespeeld. Voor een bespreking van de uitvoering van het systeem is gekozen voor twee centrale thema's: financiering en medisch noodzakelijke zorg.

Ik vervolg de route met een analyse van het recht op zorg voor de gezondheid van de onrechtmatig verblijvende vreemdeling (deelvraag 1). Het recht op zorg voor de gezondheid is één van de hogere internationale normen waaraan het systeem zal worden getoetst. Het ligt verankerd in meerdere internationale, Europese en supranationale verdragen. Jurisprudentie en aanbevelingen over dit recht zullen - voor zover relevant voor de onrechtmatig verblijvende vreemdeling - worden geanalyseerd en geïnterpreteerd. Centraal staat daarbij de vraag welke minimumaanspraken op zorg voor de gezondheid van de onrechtmatig verblijvende vreemdeling aan het internationale recht kunnen worden ontleend. Extra aandacht gaat uit naar het recht op zorg voor de gezondheid van kinderen. Bij deze analyse wordt een uitstap gemaakt naar jurisprudentie van het Europese Hof voor de Rechten van de Mens (EHRM) over de uitzetting van de ernstig zieke vreemdeling in relatie tot artikel 3 EVRM. Deze jurisprudentie biedt normatieve kaders voor de ondergrens van het recht op gezondheidszorg van de onrechtmatig verblijvende vreemdeling.

De aard van het onderzoek tot dusver is analyserend en beschrijvend. Dit hangt samen

\footnotetext{
${ }^{33}$ Thijssen 2009, p. 70 en 73.
} 
met het gegeven dat gezondheidsrecht in het algemeen en het centrale thema van dit onderzoek in het bijzonder, een horizontaal, gelaagd karakter kent. Het beschrijvende gedeelte biedt daarmee niet alleen een opmaat tot een analyse, maar is op zichzelf methodologisch en inhoudelijk van meerwaarde aangezien het aanbrengen van structuur in dit thema en met het in dit proefschrift gekozen perspectief nog niet eerder is verricht.

Het evaluerende deel van het onderzoek vangt aan met het bespreken van de vraag hoe het koppelingsbeginsel in de praktijk functioneert (deelvraag 3). De hierbij gehanteerde methode is met name jurisprudentieonderzoek op het gebied van sociale zekerheid. Ik heb een selectie gemaakt van de voor dit onderzoek meest relevante uitspraken van hogere rechters en het EHRM waarbij de rechtmatigheid van het koppelingsbeginsel aan de orde is geweest. Aan de hand van jurisprudentie onderzoek ik in hoeverre het koppelingsbeginsel in het algemeen en ten aanzien van de $\mathrm{Zvw}$ en de Wlz in het bijzonder voor de rechter in individuele gevallen houdbaar is gebleken.

$\mathrm{Na}$ het principiële onderzoek naar de werking van het koppelingsbeginsel, volgt een onderzoek naar de feitelijke werking van het koppelingsbeginsel - financiering via de bijdrageregeling voor medisch noodzakelijke zorg - in de praktijk, met name voor de kwetsbare groepen (deelvraag 4). De bronnen die hierbij worden gebruikt zijn jurisprudentieonderzoek en rapporten van diverse organisaties en toezichthouders. Voorbij het individuele geval worden de algemene tekortkomingen van het systeem kritisch onder de loep genomen.

Ik sluit het onderzoek af met een samenhangende beschouwing waarin ik systematisch waardeer of sprake is van een systeem dat overeenstemt met het recht op zorg voor de gezondheid, overige mensenrechten en gezondheidsrechtelijke principes voor zover die door internationaal en nationaal recht zijn gepositiveerd (deelvraag 5). Daarbij toets ik of de intern geldende normen conflicteren met internationaal recht en of de interne normen een consistente en consequente uitwerking van dit internationaal recht bieden. Waar toont het systeem gebreken vanuit gezondheidsrechtelijke perspectief en op welke wijze kunnen deze worden opgelost?

Het karakter van de onderzoeksvraag is deels beschrijvend en deels evaluerend. Het onderzoek kent een nationaalrechtelijke invalshoek waarbij het internationaalrechtelijke kader mede van belang is als toetsingskader.

Empirisch onderzoek naar de werking van de regulering in de praktijk maakt geen onderdeel uit van dit onderzoek. Het gaat om inventarisatie en evaluatie van de normatieve uitgangspunten (overheidsverantwoordelijkheid voor het recht op zorg voor de gezondheid) en de juridische vormgeving daarvan. Evenmin maakt rechtsvergelijking onderdeel uit van dit onderzoek. Ook al is rechtsvergelijking relevant, het was te omvangrijk in het bestek van deze studie.

\subsection{Afbakening}

Het onderzoek is enerzijds ruimer dan uitsluitend het recht op gezondheidszorg. Het omvat immers tevens een onderzoek naar uitgangspunten en uitvoering van het algehele systeem van uitsluiting van sociale voorzieningen (de Koppelingswet) van de vreemdeling. Anderzijds is het onderzoek beperkter en omvat het niet alle aspecten van het recht op gezondheid zoals de onderliggende determinanten van gezondheid.

De organisatie van de medische zorg en de toegang hiertoe in opvanglocaties van het 
Centraal Orgaan opvang asielzoekers (COA) en in vreemdelingendetentie komt aan de orde maar is op zichzelf geen onderwerp van deze studie. Centraal staat de regeling die geldt voor medische zorg verleend aan vreemdelingen die niet (meer) in een opvanglocatie verblijven die onder verantwoordelijkheid van de overheid valt.

De Nederlandse vreemdelingenwet onderscheidt verschillende categorieën vreemdelingen, afhankelijk van de nationaliteit en de aard van het verblijf van de vreemdeling. ${ }^{34}$ Het onderscheid in categorieën vreemdelingen is van belang voor de toepasselijkheid van de verschillende regelingen die betrekking hebben op de aanspraken op medische zorg. Er is sprake van toenemende bescherming naarmate het verblijfsrecht sterker is. Dit proefschrift zoomt in op de vreemdelingen met onrechtmatig verblijf in Nederland. Diverse bevindingen zullen ook geldig zijn voor bepaalde categorieën onverzekerbare vreemdelingen met rechtmatig verblijf, maar gezien de 'rechtelozere' status van mensen zonder rechtmatig verblijf is dat de categorie waar het onderzoek zich op richt. Meer specifiek ziet het met name op onrechtmatig verblijvende vreemdelingen met een asielverleden. Deze mensen zijn immers over het algemeen extra kwetsbaar gezien hun vlucht, hun verblijf in een asielzoekerscentrum en de asielprocedure. Voor de beschrijving van de gezondheidsproblemen van vreemdelingen zonder rechtmatig verblijf zal dan ook de gehele vreemdelingenketen (van aankomst tot vertrek) de revue passeren.

\subsection{De vreemdeling zonder rechtmatig verblijf (voorheen: "illegalen"): terminologie}

De term 'illegaal' (als zelfstandig naamwoord) wordt zowel internationaal als nationaal als onjuist en stigmatiserend beschouwd. Illegaal refereert aan een strafbare gedraging. Het is echter in de meeste landen - waaronder Nederland - niet strafbaar om een onrechtmatig verblijf te hebben. De onrechtmatige status valt onder het vreemdelingenrecht, dus onder de administratieve wetgeving. Daarnaast kan het definiëren van een persoon als illegaal worden beschouwd als het ontkennen van iemands menselijkheid. Cholewinski stelt dat men gemakkelijk kan vergeten dat dergelijke migranten mensen zijn die het recht hebben om overal voor de wet te worden erkend, zoals in de internationale mensenrechtenwetgeving wordt herhaald, en die ondanks hun illegale of irreguliere status over fundamentele rechten beschikken. ${ }^{35}$ Een mens kan niet illegaal zijn, zijn status wel. Platform for International Cooperation for Undocumented Migrants (PICUM) beschouwt de term illegaal als druisend tegen de Europese waarden als discriminerend, onderdrukkend en verouderd. ${ }^{36}$ Het plaatst mensen buiten de juridische orde. ${ }^{37}$

$\mathrm{Al}$ in de jaren zeventig van de vorige eeuw verzocht de Algemene vergadering van de Verenigde Naties (VN) alle VN-organen om in officiële documenten de termen ongedocumenteerd en migrantenarbeiders zonder papieren te gebruiken. ${ }^{38}$ In officiële publicaties van de Raad van Europa en de EU is het gebruik van de term irregular migrant gemeengoed

\footnotetext{
${ }^{34}$ Zie par. 2.2.

${ }^{35}$ Cholewinski 2005, p. 5.

${ }^{36}$ Picum.org.

37 Oomen, 2019, p. 260. Als alternatief voor illegalen bedacht zij het woord rechtenmensen, om de onvervreemdbaarheid van mensenrechten uit te drukken (p. 265).

${ }^{38}$ Algemene Vergadering, Maatregelen om de mensenrechten van alle migrantenarbeiders te bewaarborgen, 3449, 2433e plenaire vergadering 9 december 1975.
} 
geworden. In Nederland is het gebruik van de term illegaal al eens aan de orde gesteld bij de Nationale ombudsman. Het ging om het gebruik van het begrip door het toenmalige College voor Zorgverzekeringen (CVZ) in het kader van de voorloper van de huidige Regeling onverzekerbare vreemdelingen, destijds ook wel het illegalenfonds genoemd. De Nationale ombudsman oordeelde dat de term illegaal op de website van het CVZ onbehoorlijk was. ${ }^{39}$ De term illegaal heeft volgens de Nationale ombudsman een negatieve bijklank en werkt stigmatiserend. ${ }^{40}$

Eerder sloot ik aan bij internationale terminologie door de term irreguliere migrant te gebruiken. ${ }^{41} \mathrm{Al}$ zien we deze term steeds vaker in beleidsstukken, het gebruik ervan is (nog) geen common use. Wel wordt in de literatuur en in parlementaire stukken steeds vaker gebruik gemaakt van synoniemen zoals mensen zonder papieren, mensen zonder rechtmatig verblijf, ongedocumenteerden, vreemdelingen zonder rechtmatig verblijf, mensen zonder rechtsgeldige verblijfstitel, en - in Vlaanderen - documentloze vreemdelingen. Op al deze termen kan als kritiek worden geleverd dat ze de nadruk leggen op de uitkomst van het vreemdelingenrecht. Er wordt ook wel gepleit voor gebruik van de term 'illegalized immigrant', dat de aandacht vestigt op de politieke en institutionele processen die een mens illegaal maken. ${ }^{42}$

In dit proefschrift zal ik alle hierboven genoemde (Nederlandstalige) termen afwisselend gebruiken. De term illegalen komt wel terug bij het parafraseren van historische teksten en ingeval de originele bronnen deze term bevatten. Het is immers niet aan mij om de geschiedenis te retoucheren.

\footnotetext{
${ }^{39}$ Openbaar Rapport van de Nationale ombudsman d.d. 31 mei 2010, nr. 2010/132.

${ }^{40}$ De term 'illegalen' dekt daarnaast ook niet de volledige doelgroep van art. 122a Zvw, aangezien ook bepaalde categorieën rechtmatig verblijvende vreemdelingen daaronder vallen, die destijds ook als 'illegalen' werden geduid.

${ }^{41}$ Derckx, TvGR 2018/2, p. 121-134.

${ }^{42}$ Bauder, International Journal of Refugee Law 2014/3, p. 327-332.
} 


\title{
Hoofdstuk 2 Introductie: de vreemdeling, diens gezondheid en gebruik van de gezondheidszorg
}

\author{
De uit Syrië gevluchte Mohamad (7) is ziek: hij \\ veroudert in rap tempo. Zijn ouders denken dat hij \\ niet lang meer te leven heeft. Een Oostenrijkse \\ politicus merkt een filmpje over de jongen op social \\ media op en zorgt ervoor dat het gezin naar \\ Oostenrijk kan komen, ondanks de strikte \\ migratiepolitiek van het land. In Oostenrijk blijkt \\ Mohamad voor zijn ziekte behandeld te kunnen \\ worden en volwassen te kunnen worden. Bij de \\ ouders bestaat echter onbegrip. 'Ik dacht dat ze \\ Mohamad zouden genezen. Maar dat hebben ze \\ niet gedaan', aldus de vader van Mohamad. \\ Bron: Sahadat, de Volkskrant 2019.
}

\subsection{Inleiding}

Dit hoofdstuk bevat een introductie van de groep waarop dit proefschrift ziet en vormt een opmaat voor het verdere juridische onderzoek. Het hoofdstuk bestaat in hoofdlijnen uit drie delen.

Het eerste deel beoogt antwoord te geven op de vraag wat de Vreemdelingenwet verstaat onder de term 'vreemdeling' en meer specifiek 'de vreemdeling zonder rechtmatig verblijf'. Deze uitstap naar het vreemdelingenrecht dient ertoe om in beeld te krijgen welke categorieën vreemdelingen de Nederlandse wet kent. Zoals reeds vermeld in paragraaf 1.6, is het onderscheid in categorieën vreemdelingen van belang voor de toepasselijkheid van de verschillende regelingen die betrekking hebben op aanspraken op medische zorg. Ingegaan wordt op de constitutionele achtergrond van de term 'vreemdeling' en de verschillende categorieën vreemdelingen die Nederland kent en de niet-geregelde status van de onrechtmatig verblijvende vreemdeling (de Vw kent alleen rechtmatig verblijf).

Het tweede deel van het hoofdstuk bespreekt de gezondheidsstatus van (irreguliere) migranten en de specifieke gezondheidsproblemen waarmee zij te maken (kunnen) hebben. Alhoewel gezondheidsproblemen op zichzelf geen onderwerp zijn van het gezondheidsrecht, is bespreking ervan relevant aangezien ze samenhangen met specifieke knelpunten bij de toegang tot gezondheidszorg. Bij de bespreking van de specifieke gezondheidsproblemen is dan ook gekozen voor een aantal thema's die zich in hoofdstuk negen vertalen in juridische knelpunten.

Het derde deel gaat in op het gebruik van de gezondheidszorg door irreguliere migranten. Ongeacht aanspraken op gezondheidszorg blijkt dat er een kloof bestaat tussen de 
aanspraken en het daadwerkelijke gebruik ervan. Een aantal factoren (informele drempels) die deze kloof veroorzaken wordt belicht. Deze informele drempels illustreren de feitelijke problematiek waarmee deze groep te kampen heeft. Dit deel van het hoofdstuk beoogt dan ook deels antwoord te geven op deelvraag 4: Welke knelpunten doen zich voor bij (de toegang tot) de zorgverlening aan ongedocumenteerden (informele en formele drempels), met name kwetsbare groepen $?^{1}$

Een opmerking van methodologische aard dient te worden gemaakt. Dit hoofdstuk stoelt deels op bevindingen voortvloeiend uit empirisch onderzoek dat niet zelf is verricht. Er is onderzoek gedaan naar internationale literatuur over de gezondheid van migranten en ongedocumenteerde vreemdelingen. Daarnaast zijn rapporten van internationale en regionale (non-gouvermentele) organisaties als de Wereldgezondheidsorganisatie (WHO), Internationale Organisatie voor Migratie (IOM), European Union Agency for Fundamental Right (FRA), Dokters van de Wereld en PICUM geraadpleegd. Deze rapporten bieden waardevolle informatie over de gezondheid van migranten en hun barrières met betrekking tot de gezondheidszorg op internationaal en regionaal niveau. Ook al zijn ze niet altijd toegespitst op de Nederlandse situatie, de bevindingen uit deze onderzoeken zijn vaak universeel en gelden (vaak) ook voor vreemdelingen die in Nederland verblijven. De empirische claims uit deze onderzoeken vormen aannames voor het verdere juridische betoog.

\subsection{De (onrechtmatig verblijvende) vreemdeling}

\subsubsection{Inleiding}

Vreemdelingen zijn migranten die wegens uiteenlopende oorzaken en/of motieven in een ander land verblijven, al dan niet tijdelijk. De term 'vreemdeling' is een begrip met een breed spectrum. Aan de ene kant van het spectrum treffen we de toerist, artiest of zakenvrouw, aan de andere kant bevindt zich de vluchteling en slachtoffer van mensenhandel. De motieven van migratie variëren van vrijwillig tot gedwongen, van sociaaleconomische motieven tot gezinshereniging, van tijdelijke verblijf tot beoogd permanent verblijf. Voor een goed begrip van de term 'onrechtmatig verblijvende vreemdeling' is het van belang om dit spectrum vreemdelingrechtelijk in kaart te brengen.

\subsubsection{Constitutionele achtergrond}

De term vreemdeling komt al voor in de Bataafse Staatsregeling van $1798 .^{2}$ Artikel 50 luidde als volgt: ${ }^{3}$

'De Maatschappij ontvangt alle Vreemdelingen, die de weldaad der vrijheid vreedzaam wensen te genieten, in haar midden, verleenende denzelven alle zekerheid en bescherming'.

\footnotetext{
${ }^{1}$ Dit hoofdstuk ziet op de informele drempels. De formele drempels komen in hoofdstuk negen aan bod.

${ }^{2}$ Drupsteen 2013, p. 316.

${ }^{3}$ De Gaay Fortman wijst op de 'bijzondere hartelijke bewoording' van deze bepaling, De Gaay Fortmann 2016, p. 195.
} 
Nationaliteit had destijds nog betrekkelijke relevantie; status en maatschappelijk succes waren van meer betekenis. ${ }^{4}$ De grondwet van 1815 introduceerde het begrip Nederlander, maar regelde het begrip vreemdeling nog niet. De grondwet van 1840 bracht hierin geen wijziging. Met de komst van de grondwet van 1848 werd duidelijkheid verschaft over het onderscheid tussen Nederlanders en de juridische status van vreemdelingen. ${ }^{5}$ Net als in de voorgaande grondwetten werd bepaald dat allen die zich op het grondgebied van het Rijk bevinden, hetzij ingezetenen, hetzij vreemdelingen, gelijke aanspraak hebben op bescherming van persoon en goederen. ${ }^{6}$ Nieuw was de bepaling over toelating en uitzetting van vreemdelingen, waarbij voor de materiële rechtspositie werd verwezen naar de wet. ${ }^{7}$ Ook voor de vraag wie Nederlander is, werd verwezen naar de wet. De band tussen staat en nationaliteit kreeg met deze grondwet vorm en werd steeds sterker. ${ }^{8}$

Het nationaliteitsbeginsel zien we terug in de huidige definitie van de vreemdeling volgens de Rijkswet op het Nederlandschap (Rwn). ${ }^{9}$ Een vreemdeling is 'hij die de Nederlandse nationaliteit niet bezit. ${ }^{10}$ Dit is een engere omschrijving dan die uit de Vw: een vreemdeling is volgens deze wet 'ieder die de Nederlandse nationaliteit niet bezit en niet op grond van een wettelijke bepaling als Nederlander moet worden behandeld'. ${ }^{11}$ De huidige grondwet kent het discriminatieverbod in artikel 1, dat ook voor vreemdelingen geldt.

Tot de eerste Vreemdelingenwet uit 1849 kende Nederland geen landelijk vreemdelingenbeleid. De Vreemdelingenwet 1849 legde voor het eerst vast welke vreemdelingen Nederland mochten binnenkomen en wie als ongewenst werden beschouwd. ${ }^{12}$ Alle vreemdelingen die voldoende middelen van bestaan hadden, of door werkzaamheid konden verkrijgen, werden toegelaten. ${ }^{13} \mathrm{Na}$ de Eerste Wereldoorlog verscherpte de Nederlandse overheid het vreemdelingenbeleid met de Wet toezicht vreemdelingen in 1919 en de Wet op de grensbewaking in 1920. Hiermee ontstond een wettelijke basis voor het uitsluiten van ongewenste vreemdelingen.

\subsubsection{Categorieën vreemdelingen}

Er zijn verschillende categorieën vreemdelingen te onderscheiden, afhankelijk van de nationaliteit en de aard van het verblijf van de vreemdeling. De nationaliteit van een vreemdeling is van doorslaggevende betekenis voor zijn rechtspositie in Nederland waaronder de voorwaarden voor toegang, toelating en bestendiging van het verblijfsrecht. De aard van het verblijf is relevant voor het recht op toekenning van verstrekkingen, voorzieningen en uitkeringen. Over het algemeen geldt dat er een toenemende aanspraak op rechten is naarmate het verblijfsrecht sterker is. Dit uitgangspunt wordt weerspiegeld in artikel 11 lid $1 \mathrm{Vw}$, dat bepaalt

\footnotetext{
${ }^{4}$ Drupsteen 2013, p. 317.

${ }^{5}$ Drupsteen 2013, p. 321.

${ }^{6}$ Art. 3 Grondwet 1948.

${ }^{7}$ Art. 3 lid 2 Grondwet 1948.

${ }^{8}$ Vermeulen 2019, p. 2.

${ }^{9}$ Wet van 19 december 1984, Stb. 1984, 628, laatstelijk gewijzigd bij de Wet van 17 juni 2010 Stb. $2010,242$.

${ }^{10}$ Art. 1 lid 1 sub 2 Rwn. Art. 2 lid 1 van de Grondwet bepaalt dat de wet regelt wie Nederlander is. Dit is uitgewerkt in de Rwn.

${ }^{11}$ Art. 1 Vw.

${ }^{12}$ Wet van 13 augustus 1849, tot regeling der toelating en uitzetting van vreemdelingen, Stb. nr. 39.

13 Art. 1 Vreemdelingenwet 1849.
} 
dat de aanspraken van de vreemdeling die rechtmatig verblijf heeft in overeenstemming zijn met de aard van het verblijf (zie paragraaf 2.2.3.2). De aard van het verblijf speelt in dit proefschrift een grotere rol dan de nationaliteit. Voor de volledigheid wordt hier evenwel op beide typen onderscheidingscriteria ingegaan.

\subsubsection{Nationaliteit}

Het vreemdelingenrecht onderscheidt grofweg twee categorieën vreemdelingen: Unieburgers en derdelanders. Burger van de Unie is een ieder die de nationaliteit van een lidstaat bezit. Unieburgers en hun naaste familieleden hebben het recht om zich vrij te verplaatsen binnen de EU en om vrij te verblijven op het grondgebied van de lidstaten (recht op vrij verkeer van personen, artikel 21 Verdrag betreffende de werking van de Europese Unie (VWEU) ${ }^{14}$. Zij verkrijgen hun verblijfsrecht van rechtswege als ze aan de voorwaarden van Richtlijn 2004/38 (Unieburgersrichtlijn) ${ }^{15}$ voldoen.

Derdelanders zijn burgers van een land dat niet tot de EU behoort. Hun migratierechtelijke positie is onderdeel van het Unierecht. Toen in de jaren tachtig van de vorige eeuw de personencontroles aan de binnengrenzen werden afgeschaft, vreesden de lidstaten voor zogenoemd 'asylum shopping' door derdelanders. Besloten werd om het toelatingsbeleid voor derdelanders te harmoniseren. In 1999 werd in het Verdrag van Amsterdam de communautaire bevoegdheid voor een gemeenschappelijk Europees asielbeleid vastgelegd. De eerste fase bestond uit de vaststelling van minimumnormen voor de definitie van vluchtelingschap en subsidiaire bescherming, de asielprocedure en de opvang van asielzoekers. Het Verdrag van Lissabon (2009) vormde het fundament voor de tweede fase, het Gemeenschappelijk Europees Asiel Systeem (GEAS). Het systeem van het GEAS bestaat uit een aantal verordeningen en richtlijnen, zoals de Procedurerichtlijn (PRi II) ${ }^{16}$, de Definitierichtlijn ${ }^{17}$ (DRi II) en de Opvangrichtlijn (ORi II) ${ }^{18}$.

Derdelanders krijgen pas verblijfsrecht in een lidstaat na een besluit daartoe van de overheid. In Nederland is dat geregeld in artikel 14 (reguliere verblijfsgronden) en artikel 28 Vw (asielgronden). Het reguliere verblijfsrecht is altijd gekoppeld aan een specifiek verblijfsdoel. Denk aan gezinshereniging, arbeid en studie. Bij toekenning van asiel is bepalend wat de situatie is in het herkomstland. ${ }^{19} \mathrm{Er}$ is dus een scheiding in de Vw tussen asielzoekers

\footnotetext{
${ }^{14}$ Verdrag betreffende de werking van de Europese Unie, Rome, 25-03-1957.

${ }^{15}$ Richtlijn 2004/38/EG Van het Europees Parlement en de Raad van 29 april 2004 betreffende het recht van vrij verkeer en verblijf op het grondgebied van de lidstaten voor de burgers van de Unie en hun familieleden, $P b E U$ 2004, L 229/35.

${ }^{16}$ Richtlijn 2013/32/EU van het Europees Parlement en de Raad van 26 juni 2013 betreffende gemeenschappelijke procedures voor de toekenning en intrekking van de internationale bescherming: Procedurerichtlijn (PRi II) herschikking van Richtlijn 2005/85/EG, PbEU 2013, L 180/60.

${ }^{17}$ Richtlijn 2011/95/EU van 13 december 2011 inzake normen voor de erkenning van onderdanen van derde landen of staatlozen als personen die internationale bescherming genieten, voor een uniforme status voor vluchtelingen of voor personen die in aanmerking komen voor subsidiaire bescherming, en voor de inhoud van de verleende bescherming: Definitierichtlijn (DRi II) herschikking van Richtlijn 2004/83/EG, PbEU 2011, L $337 / 9$.

${ }^{18}$ Richtlijn 2013/33/EU van 26 juni 2013 van het Europees Parlement en de Raad tot vaststelling van normen voor de opvang van verzoekers om internationale bescherming: Opvangrichtlijn (ORi II), herschikking van Richtlijn 2003/9/EG, PbEU 2013, L 180/96.

${ }^{19}$ Zwaan e.a. 2018 , p. 41.
} 
en overige vreemdelingen, die toelating vragen op andere gronden, de zogeheten reguliere vreemdelingen.

\subsubsection{Aard van het verblijf}

De aard van het verblijf van de vreemdeling kan rechtmatig of onrechtmatig zijn. De aard van het verblijf is bepalend voor het al dan niet in aanmerking komen voor voorzieningen.

Voor de juridische kwalificatie van de aard van het verblijf is de Schengengrenscode $(\mathrm{SGC})^{20}$ van belang. Deze bevat regels voor de grenscontrole en toezicht aan de buitengrenzen van het Schengengebied. Op grond van de SGC kan een derdelander binnen de EU alleen rechtmatig toegang hebben tot de EU wanneer daar een grondslag voor is. Zonder een grondslag verblijft de vreemdeling onrechtmatig. ${ }^{21}$ Volgens de Terugkeerrichtlijn (TRi) ${ }^{22}$ is illegaal verblijf 'de aanwezigheid op het grondgebied van een lidstaat van een onderdaan van een derde land die niet of niet langer voldoet aan de voorwaarden voor toegang tot bedoeld grondgebied die zijn vastgesteld in de Schengengrenscode, of aan andere voorwaarden voor toegang resp. verblijf of vestiging in die lidstaat'. ${ }^{23}$ Asielzoekers vallen niet onder het toepassingsbereik van de TRi. ${ }^{24}$ De TRi schrijft voor dat indien wordt vastgesteld dat een derdelander illegaal in Nederland verblijft en er geen reden is om hem een verblijfsvergunning te verlenen, er een terugkeerbesluit moet worden genomen (artikel $6 \mathrm{TRi}$ ).

Op grond van de in 1998 ingevoerde Koppelingswet kan alleen de vreemdeling die rechtmatig in Nederland verblijft aanspraak maken op collectieve voorzieningen. Nietrechtmatig verblijvende vreemdelingen zijn uitgesloten van de toegang tot collectieve voorzieningen (zie hoofdstuk 4).

Artikel $8 \mathrm{Vw}$ bevat een opsomming van de dertien gronden waarop een vreemdeling rechtmatig in Nederland verblijft. Deze opsomming is niet limitatief: op grond van artikel 112 Vw kunnen ter uitvoering van internationale verplichtingen (ook) regels worden gesteld (in een Algemene Maatregel van Bestuur, AMvB) met betrekking tot rechtmatig verblijf. ${ }^{25}$

De gronden die in artikel 8 Vw staan genoemd, worden door Lodder samengevat als: ${ }^{26}$

1. rechtmatig verblijf op grond van een vergunning;

2. rechtmatig verblijf op grond van het Unierecht;

3. rechtmatig verblijf in afwachting van de beslissing op een aanvraag;

4. rechtmatig verblijf op grond van de wet.

\footnotetext{
${ }^{20}$ Verordening 2016/399 betreffende een Uniecode voor de overschrijding van de grenzen door personen.

${ }^{21}$ Art. 6 SGC.

${ }^{22}$ Richtlijn 2008/115/EG van het Europees Parlement en de Raad van 16 december 2008 over gemeenschappelijke normen en procedures in de lidstaten voor de terugkeer van onderdanen van derde landen die illegaal op hun grondgebied verblijven, $P b E U$ 2008, L 348/98 (Terugkeerrichtlijn of TRi).

${ }^{23}$ Art. 3 lid 2 TRi.

${ }^{24}$ Art. 9 TRi.

${ }^{25}$ Het binaire systeem van de Vw (de strikte scheiding tussen rechtmatig en niet-rechtmatig verblijf) is in sommige situaties bij asielzoekers moeilijk te handhaven omdat het EU-recht een ander stelsel kent met verschillende kwalificaties (onder meer rechtmatig verblijf 'legaal' verblijf, verblijf met toestemming, verblijf in verband met uitstel van vertrek), Zwaan e.a. 2020, p. 389-390.

${ }^{26}$ Lodder 2018, p. 30.
} 
Ad 1. Het gaat hier om rechtmatig verblijf op grond van één van de vier verblijfsvergunningen ex Vw: de verblijfsvergunning regulier voor bepaalde tijd, de verblijfsvergunning regulier voor onbepaalde tijd, de verblijfsvergunning asiel voor bepaalde tijd en de verblijfsvergunning asiel voor onbepaalde tijd. ${ }^{27}$

Ad 2. Unieburgers genieten zoals hierboven vermeld het vrij verkeer van personen.

Ad 3. Deze categorie betreft vreemdelingen die een aanvraag tot het verlenen van een verblijfsvergunning hebben ingediend. Er is dan sprake van rechtmatig verblijf tot het moment waarop een beslissing op de aanvraag is genomen. ${ }^{28}$

Ad 4. Het gaat hier om vreemdelingen die niet mogen worden uitgezet zolang het gelet op de gezondheidstoestand van de vreemdeling of een van zijn gezinsleden niet verantwoord is om te reizen. ${ }^{29}$

Voldoet een vreemdeling niet (meer) aan één van in artikel 8 genoemde gronden, dan verblijft hij niet-rechtmatig in Nederland. Hij dient Nederland uit eigen beweging te verlaten (de vertrekplicht ex artikel $61 \mathrm{Vw}$, zie hoofdstuk 8). In de artikelen 9 en 9a Vw is bepaald uit welke documenten rechtmatig verblijf blijkt.

Het onderscheid in categorieën vreemdelingen is van belang voor de toepasselijkheid van de verschillende regelingen die betrekking hebben op de aanspraken op medische zorg. De Regeling artikel 122a Zvw is van toepassing op bepaalde categorieën vreemdelingen met rechtmatig verblijf en vreemdelingen met onrechtmatig verblijf. ${ }^{30}$ In hoofdstuk 4 wordt hier nader op ingegaan.

Samengevat bestaat de groep onrechtmatig verblijvende vreemdelingen grofweg uit:

- mensen die zonder geldige papieren Nederland zijn binnengekomen;

- mensen die Nederland legaal zijn binnengekomen, maar zijn gebleven nadat hun verblijfsrecht is verstreken;

- $\quad$ uitgeprocedeerde asielzoekers die in Nederland zijn gebleven.

$\mathrm{Na}$ deze verkenning van het begrip 'onrechtmatig verblijvende vreemdeling', zoomt de volgende paragraaf in op de gezondheidsstatus en gezondheidsproblemen van vreemdelingen (migranten) in het algemeen en die van onrechtmatig verblijvende vreemdelingen in het bijzonder.

\subsection{Gezondheid, gezondheidsdeterminanten en publieke gezondheidszorg}

2.3.1 Het concept gezondheid

\footnotetext{
${ }^{27}$ Art. 8 sub a-d Vw.

${ }^{28}$ Art. 8 sub f en g Vw jo art. 3.1 lid 1 Vreemdelingenbesluit $(\mathrm{Vb})$. Met uitzondering van twee situaties, te weten als de vreemdeling een herhaalde aanvraag heeft ingediend (art. 3.1 lid 1 sub a jo. art. 3.1 lid $2 \mathrm{Vb}$ ) en het indienen van een aanvraag die kan worden afgewezen wegens gevaar voor de openbare orde of de nationale veiligheid (art. $3.1 \mathrm{Vb})$.

${ }^{29}$ Art. $64 \mathrm{Vw}$ jo art. 8 sub j Vw.

${ }^{30}$ Art. $122 \mathrm{a}$ lid 1 sub a en b Zvw.
} 
Preliminair is van belang om vast te stellen wat onder gezondheid wordt verstaan. Het concept gezondheid kan vanuit twee disciplines worden benaderd: vanuit de geneeskunde en vanuit public health. ${ }^{31}$ Gaat het bij geneeskunde over het algemeen over de gezondheid van het individu, public health richt zich op de bevordering van de volksgezondheid en het treffen van collectieve maatregelen die voor de bevordering van de volksgezondheid noodzakelijk zijn. ${ }^{32}$ Gezondheidszorg is vanuit het perspectief van public health noodzakelijk, maar niet toereikend voor gezondheid. ${ }^{33}$

De meest wijdverbreide definitie van gezondheid is die van de WHO: 'gezondheid is een toestand van volledig lichamelijk, geestelijk en sociaal welzijn en niet slechts de afwezigheid van ziekte of zwakheid' ${ }^{34}$ Destijds was dit een baanbrekende definitie, omdat gezondheid niet louter als afwezigheid van ziekte werd beschouwd maar ook het welbevinden op andere niveaus includeerde. Toch bleef de definitie niet zonder kritiek. ${ }^{35}$ Het adjectief 'volledig' leidde ertoe dat vrijwel iedereen als niet gezond, dus ziek, zou kunnen worden beschouwd. ${ }^{36}$ Met het oog op de toename van het aantal chronische ziekten, zou het streven naar 'volledig' medicaliserend werken. ${ }^{37} \mathrm{Er}$ ontstond dan ook behoefte aan een meer dynamische benadering van het begrip. Huber e.a. ontwikkelden een nieuwe omschrijving, die gezondheid beschouwt als: 'Het vermogen zich aan te passen en een eigen regie te voeren, in het licht van de fysieke, emotionele en sociale uitdagingen in het leven' ${ }^{38}$ Volgens dit concept kunnen ook mensen met ziekten, letsels of gebreken een goede gezondheid hebben, omdat de nadruk primair ligt op de mogelijkheid om te functioneren en op het voeren van een eigen regie.

Tegen deze omschrijving zijn bezwaren ingebracht. Zo zou het te eenzijdig het accent leggen op gedrag. ${ }^{39}$ Opvallend is dat het element 'welzijn' in het concept van Huber e.a. ontbreekt. Uitgaande van de definitie van de WHO, omvat welzijn immers zowel lichamelijk, geestelijk als sociaal welbevinden. Het gevolg van de definitie van de WHO is dat iemand die medisch gezien niet ziek is ('disease'), zich toch kan ziek voelen (ervaren ziekte, 'illness') als hij bijvoorbeeld verstoken is van een sociaal netwerk of continu stress ervaart, wat veelal het geval is bij ongedocumenteerden. ${ }^{40}$ In het concept van Huber e.a. is dat niet (automatisch) het geval. Daarentegen is het element 'het voeren van een eigen regie' wel interessant vanuit het

\footnotetext{
${ }^{31}$ Mann e.a., Health and Human Rights Journal 1994/1, p. 6-23. Er bestaat geen goede Nederlandse vertaling voor het begrip public health. Onderdelen van public health in Nederland zijn publieke gezondheidszorg, sociale geneeskunde en gezondheidswetenschappen, Mackenbach \& Stronks, 2016, p. 19-20.

${ }^{32}$ Mackenbach \& Stronks 2016, p. 19.

${ }^{33}$ Mann e.a., Health and Human Rights Journal 1994/1, p. 6-23.

${ }^{34}$ Statuut van de Wereldgezondheidsorganisatie, New York, 22-07-1946.

${ }^{35}$ Onder meer Jadad \& O'Grady, BMJ 2008, die de uitnodiging deden om de definitie te herzien.

${ }^{36}$ Smith, BMJ Group Blogs 2008.

${ }^{37}$ Volgens Toebes dient de definitie echter te worden beoordeeld vanuit het perspectief van naoorlogs idealisme, Toebes, TvGR 2016/8, p. 513-526 2016, p. 519, onder verwijzing naar Toebes 1999, p. 23.

${ }^{38}$ Huber e.a., $N T v G$ 2016;160:A77720.

${ }^{39}$ Van der Stel, MC 8 juni 2016. Volgens hem ontbreekt het biopsychosociale en culturele aspect in de definitie. Van der Stel noemt als voorbeeld dat iemand die in aanmerking komt voor euthanasie wegens ondraaglijk lijden volgens deze definitie toch gezond zou zijn, omdat de betrokkene zich aanpast en een eigen regie voert. Patiënten blijken gezondheid overigens veel breder te zien dan artsen en beleidsmakers, wat 'positieve gezondheid' wordt genoemd, Huber e.a., NTvG 2016;160:A77720.

${ }^{40}$ Iemand die niet gezond is volgens de definitie, is niet automatisch ziek in de medische zin van het woord ('disease'). Omgekeerd kan iemand die ziek is, zich toch gezond voelen. Er bestaat een verschil tussen objectieve vast te stellen ziekte ('disease') en de subjectieve ervaring van ziekte ('illness'), Mackenbach \& Stronks 2016, p. 32.
} 
perspectief van de irreguliere migrant. Dit kan worden opgevat als het beschikken over autonomie en zelfbeschikkingsrecht. Ongedocumenteerde vreemdelingen - met name in vreemdelingendetentie - schort het immers vaak aan het kunnen voeren van die eigen regie. ${ }^{41}$

De WHO nam het concept van Huber e.a. overigens niet over. ${ }^{42}$ In de rest van dit hoofdstuk wordt dan ook uitgegaan van gezondheid in het licht van de definitie van de WHO, mede omdat de meeste (sociaalwetenschappelijke) literatuur op deze definitie is gebaseerd.

\subsubsection{Gezondheidsdeterminanten}

Iemands gezondheid wordt mede bepaald door gezondheidsdeterminanten. Determinanten van (on)gezondheid zijn alle factoren die de volksgezondheid beïnvloeden. Dit kunnen zowel negatieve factoren als positieve factoren zijn. Er wordt een onderscheid gemaakt in persoonsgebonden factoren, leefstijl en de fysieke en sociale omgeving (leefomstandigheden). Preventie, zorg en maatschappelijke determinanten zijn eveneens van invloed op de volksgezondheid. ${ }^{43}$ Ziekten of aandoeningen werken als determinant voor andere ziekten of gezondheid. ${ }^{44}$

Migranten staan tijdens het gehele migratieproces (vanaf de start, tijdens de reis en bij aankomst van hun bestemming) bloot aan risico's voor hun gezondheid. Migratie wordt dan ook als één van de sociale determinanten voor ongezondheid beschouwd. ${ }^{45}$ Ongedocumenteerde migranten hebben vanwege hun sociaal-economische status (SES) te maken met een opeenstapeling van negatieve met name sociale gezondheidsdeterminanten. De juridische status van ongedocumenteerden op zichzelf vormt een determinant voor zowel de gezondheid als voor de toegankelijkheid van zorg. ${ }^{46}$ Post-migratie stressoren zoals een lange asielprocedure, werkloosheid en isolatie worden geassocieerd met het ontwikkelen van de depressie en andere psychische problemen. ${ }^{47}$ Sociale uitsluiting - het niet volledig kunnen participeren in de samenleving van het land van ontvangst - is eveneens een gezondheidsdeterminant. Armoede is zowel een oorzaak als een gevolg van sociale uitsluiting en heeft een negatief effect op gezondheid, evenals gebrek aan huisvesting, adequaat onderwijs goede voeding, vervoer en sociaal netwerk. ${ }^{48}$

Dokters van de Wereld concludeert dat er bij ongedocumenteerden een risico bestaat op het ontstaan van een vicieuze cirkel. Diverse determinanten zoals de toegankelijkheid van de zorg en het zorg zoekend gedrag van het individu hebben een negatieve uitwerking op de gezondheid van de ongedocumenteerde migrant. ${ }^{49}$ De onzekere verblijfsstatus leidt tot een voortdurende angst voor arrestatie en uitzetting naar het land van herkomst. In combinatie met

\footnotetext{
${ }^{41}$ Aldus ook de Nationale ombudsman 2013, p. 5.

${ }^{42}$ Zie Huber e.a., BMJ Open 2016;5:e010091.

${ }^{43}$ Mackenbach \& Stronks 2016, p. 37.

${ }^{44}$ Volksgezondheidenzorg.info (laatst geraadpleegd 3 augustus 2020).

${ }^{45}$ Matlin e.a., Public Health Reviews 2018/27.

${ }^{46}$ Dokters van de Wereld 2016, p. 47.

${ }^{47}$ De combinatie van zowel fysieke als psychologische symptomen die migranten ervaren die met chronische en multiple stressoren te maken hebben wordt ook wel het Ulysses syndroom genoemd, onder meer Achotegui, Psychoanalytic Dialogues 2019/3, p. 252-268.

48 Wilkinson \& Marmot, WHO 2003, p. 263.

${ }^{49}$ Dokters van de Wereld 2016, p. 47. Overigens werd geen studie verricht naar de positieve interactie tussen gezondheidsdeterminanten.
} 
onwetendheid zorgt dit ervoor dat de meerderheid van de ongedocumenteerden denkt dat een Nederlandse huisarts hen zou aangeven bij autoriteiten. ${ }^{50}$

\subsubsection{Publieke gezondheidszorg}

Publieke gezondheid is gedefinieerd als 'wat wij als samenleving collectief kunnen doen om de omstandigheden te verbeteren waarin mensen gezond kunnen zijn'. ${ }^{5}$ Publieke gezondheidszorg ziet op de gezondheidsbeschermende en -bevorderende maatregelen die worden getroffen voor de bevolking als geheel of voor specifieke groepen daarbinnen, met inbegrip van het voorkómen en het voortijdig opsporen van ziekten (artikel 1 aanhef en sub c Wet publieke gezondheid, Wpg). Het ziet op de benadering van collectieve gezondheidsvraagstukken, met de gezondheidsdeterminanten als uitgangspunt. ${ }^{52}$ Voorbeelden van publieke gezondheidzorg zijn het voorkomen en bestrijden van infectieziekten, het verrichten van bevolkingsonderzoek, het geven van gezondheidsvoorlichting en de jeugdgezondheidszorg. Als een bevolkingsgroep een lagere gezondheidsstatus heeft is dat van negatieve invloed op de gezondheidsresultaten van de samenleving als geheel. ${ }^{53}$ De gezondheid van (ongedocumenteerde) migranten is dan ook een zaak van publieke gezondheid.

\subsection{Algemene gezondheid en gezondheidsproblemen van (irreguliere) migranten}

\subsubsection{Gezondheidsstatus van vluchtelingen en migranten}

Als uitgangspunt kan worden aangenomen dat vluchtelingen en migranten met dezelfde gezondheidsissues te maken (kunnen) hebben als ieder ander mens. Over de gezondheid van migranten bestaan echter veel mythen. Eén daarvan is dat migranten besmettelijke ziektes met zich meebrengen naar het gastland. Uit onderzoek is echter gebleken dat bijvoorbeeld een aanzienlijk deel van de vluchtelingen en migranten die hiv-positief is, wordt besmet nadat zij in de regio zijn aangekomen, met inbegrip van degenen die zijn verhuisd uit landen met een hoge hiv-endemiciteit. ${ }^{54}$ Een andere mythe is dat de gezondheid van migranten slechter is dan die van de autochtone bevolking van het land van ontvangst. Dit is echter niet het geval. De gezondheidstoestand van migranten is vaak beter is dan de meerderheid van de bevolking van het gastland, maar dit oorspronkelijke gezondheidsvoordeel neemt geleidelijk af tot op of zelfs onder het nationale gezondheidsniveau. ${ }^{55}$ Dit wordt ook wel het 'healthy migrant effect' genoemd. De juridische status en de reden van migratie hebben eveneens invloed op de gezondheid.

Migranten lopen door slechte leefomstandigheden of aanpassingsproblemen in het gastland waar ze verblijven een groter risico op infectieziektes. ${ }^{56}$ Tuberculose (tbc) bijvoorbeeld is voornamelijk een ziekte van armoede. Sociale achterstand en ondermaatse levensomstandigheden vergroten het risico op tbc. Migranten zijn dan ook vaker dragers van

\footnotetext{
${ }^{50}$ Dokters van de Wereld, 2016.

${ }^{51}$ IOM 1998.

${ }^{52}$ Leenen e.a. 2017 , p. 555.

${ }^{53}$ WHO 2018, p. 3.

${ }^{54}$ WHO 2018, p. 11-12.

${ }^{55}$ Ingleby \& Petrova-Benedict 2016, p. 13, Gkiouleka e.a., European Journal of Public Health 2018/5, p 54-60.

${ }^{56}$ WHO Europe 2018.
} 
tbc dan de autochtone bevolking. In Europa komt multidrug-resistente tbc (MDR-TB) vaker voor onder vluchtelingen en migranten dan onder de bevolking van het gastland. Dit houdt verband met tekortkomingen in de gezondheidszorg wat betreft de opsporing van latente tbc, laattijdige start van de behandeling en onvolledige behandelingen. ${ }^{57}$

De kans op niet-overdraagbare ziektes zoals cardiovasculaire aandoeningen en kanker stijgt als migranten in arme leefomstandigheden terecht komen. Post-migratie stressoren zoals een lange asielprocedure, werkloosheid en isolatie worden negatief geassocieerd met het ontwikkelen van depressie en andere psychische problemen. Zowel kinderen als volwassenen kunnen te maken krijgen met seksueel geweld gedurende de reis en zelfs na aankomst in hun gastland in Europa. Mensen met een migratieachtergrond hebben vaker te maken met armoede, sociale exclusie en gezondheidsproblemen dan de autochtone bevolking. ${ }^{58}$ Veel gezondheidsrisico's hangen samen met sociale omstandigheden. Hieronder valt uitsluiting, huisvesting, voeding, onderwijs, toegang tot gezondheidszorg, isolatie en afzondering en gezondheidsproblemen en -risico's op het werk. Een lagere SES is op zichzelf al nadelig voor de gezondheid. ${ }^{59}$

\subsubsection{Gezondheidsstatus van asielzoekers}

De duur van de asielprocedure is een belangrijke risicofactor voor psychiatrische problemen. De factor 'duur van verblijf' vertegenwoordigt vermoedelijk een opeenhoping van postmigratiestressfactoren, zoals: de angst om weggestuurd te worden; onzekerheid over de duur of het resultaat van de asielprocedure; gebrek aan werk, geld en geschikte huisvesting; het zich zorgen maken over of het missen van familieleden in het land van oorsprong; en zorgen over de kinderen. ${ }^{60}$

Asielzoekers worden verplicht gescreend op tbc bij binnenkomst in Nederland. De screening dient zowel een individueel (vroege diagnose en adequate behandeling van tbc) als een publiek belang (voorkomen van transmissie van tbc in de doelgroep van immigranten en de algemene populatie in Nederland). ${ }^{61}$ Van 15 maart - 28 april 2020 werd de asielprocedure in Nederland opgeschort wegens het coronavirus. Nieuwe asielzoekers krijgen een medische intake waarbij sindsdien speciaal wordt gelet op coronaklachten. Ook wordt een temperatuurmeting gedaan. ${ }^{62}$

\subsubsection{Gezondheidsstatus van vreemdelingen in vreemdelingendetentie}

Vreemdelingen in vreemdelingendetentie vormen een extra kwetsbare groep. Detentie is op zichzelf een grote stressfactor. Het heeft een negatief effect op de gezondheid. ${ }^{63}$ Door het verlies van autonomie en controle over het eigen leven neemt de kans op depressie toe. Diverse wetenschappelijke publicaties en onderzoeksrapporten wijzen op de risico's van gezond-

\footnotetext{
${ }^{57}$ WHO 2018, p. 11-12.

${ }^{58}$ Stronks e.a., BMC Public Health 2013, 13:402.

${ }^{59}$ Mackenbach \& Stronks, p. 117.

${ }^{60}$ Laban e.a., Tijdschrift voor Psychiatrie 2005/11, p. 743-752.

61 Beleid screening asielzoekers en immigranten, 11 december 2015, Commissie voor Praktische Tuberculosebestrijding, p. 3.

${ }^{62}$ COA.nl, dossier coronavirus (laatst geraadpleegd 3 augustus 2020).

${ }^{63}$ WHO 2018, p. 9, 'Een ongezonde wet' 2018, p. 6.
} 
heidsschade ten gevolge van vreemdelingendetentie. Dit hangt samen met de onduidelijkheid over de duur van de detentie, het gevoel ten onrechte als een crimineel behandeld te worden en de onzekerheid over de toekomst. Detentie kan daardoor leiden tot een hoge prevalentie van angststoornissen, depressie, Post Traumatische Stress Stoornis (PTSS), automutilatie en suïcidale gedachten en in mindere mate ook psychoses. Ook mensen die in goede gezondheid het detentiecentrum binnenkomen kunnen te maken krijgen met slapeloosheid, verminderde eetlust, stress en depressie. Daarnaast tast detentie de autonomie van mensen aan. ${ }^{64}$

\subsubsection{Gezondheidsstatus van vreemdelingen zonder rechtmatig verblijf}

Er is op Europees niveau weinig wetenschappelijk bewijs over de gezondheidsstatus van irreguliere migranten vergeleken met die van onderdanen of andere categorieën migranten. Dit hangt samen met het feit dat het lastig te bepalen is of een steekproef representatief is voor de gehele populatie irreguliere migranten, omdat de demografische kenmerken van deze populatie niet precies bekend zijn. Nederland behoort tot de landen waar het nemen van steekproeven mogelijk is omdat ongedocumenteerden toegang hebben tot de reguliere zorg en hun medische dossiers identificeerbaar zijn. ${ }^{65}$ Methodologische problemen ten aanzien van het uitvoeren van epidemiologisch onderzoek naar irreguliere migranten maken het echter lastig om een goed beeld te krijgen van de omstandigheden waardoor deze mensen in het bijzonder risico lopen.

Ondanks het gebrek aan harde data zijn er wel rapporten over de sociale determinanten voor gezondheid die leren dat de omstandigheden waarin ongedocumenteerden leven het risico op een breed scala van gezondheidsproblemen verhogen. Deze omvatten zowel nietoverdraagbare als besmettelijke ziekten, werkgerelateerde ziekten en letsel, seksuele problemen en problemen met betrekking tot reproductieve gezondheid, en het negatieve effect van discriminatie op zowel de fysieke als mentale gezondheid. ${ }^{66}$ Zo lopen ongedocumenteerde migranten in Europa een sterk verhoogd risico op een infectie met chlamydia, hepatitis B/C, hiv en tbc in vergelijking tot autochtone populaties of vergeleken met migranten met een verblijfsvergunning. De meeste hiv-infecties worden opgelopen na aankomst in Europa. ${ }^{67}$

Ongedocumenteerde migranten in Europa hebben een verhoogd risico op gezondheidsproblemen. Infectieziekten, gynaecologische aandoeningen, psychosociale en psychiatrische aandoeningen en zwangerschapsgerelateerde problematiek komen vaak voor, naast een slechtere subjectieve gezondheidsbeleving. De problematiek is grotendeels het gevolg van een combinatie van complexe leefomstandigheden en uitgestelde of ontoegankelijke medische zorg. ${ }^{68}$

Al zijn er weinig (recente) cijfers bekend over de gezondheidsproblemen van ongedocumenteerde migranten in Nederland - wetenschappelijke studies daarover zijn schaars en versnipperd - de studies die er zijn laten zien dat er reden is tot zorg over de gezondheidstoestand van deze groep. ${ }^{69}$ Zo hebben Rietveld e.a. onderzoek verricht naar de gezondheidsproblemen van migranten zonder geldige verblijfsvergunning die zich melden met

\footnotetext{
64 'Een ongezonde wet' 2018, p. 6. Zie de aldaar aangehaalde literatuur.

${ }^{65}$ Ingleby \& Petrova-Benedict 2016, p. 13.

${ }^{66}$ Ingleby \& Petrova-Benedict 2016, p. 15.

${ }^{67}$ Dokter van de Wereld 2016, p. 48.

${ }^{68}$ Dokters van de Wereld 2016, p. 8.

${ }^{69}$ Dokters van de Wereld 2012, Dokters van de Wereld 2015.
} 
een vraag om 24-uursopvang in Amsterdam. Het grootste deel van deze mensen had te maken met gezondheidsklachten. Vooral stress en daaraan gerelateerde somatische klachten (zoals hartkloppingen en pijn op de borst) kwamen vaak voor. ${ }^{70}$ Hieronder wordt een aantal specifieke gezondheidsproblemen toegelicht.

\subsection{Specifieke gezondheidsproblemen van vreemdelingen zonder rechtmatig verblijf}

\subsubsection{Mondgezondheid}

Mondzorg is een essentieel element van de algehele gezondheid en het welbevinden van de mens. ${ }^{71}$ Aandoeningen in de mond kunnen een grote impact hebben op het lichamelijk en geestelijk welbevinden en op het maatschappelijk functioneren. ${ }^{72}$ De mond kan niet los worden gezien van het lichaam: beide hebben invloed op elkaar. ${ }^{73}$ Goede mondzorg is dan ook van belang voor de algehele gezondheid. Een goede preventie is daar onderdeel van. Juist preventie blijkt niet vanzelfsprekend voor mensen met een andere culturele achtergrond en de 'cultuur van overleven' van veel ongedocumenteerden. ${ }^{74}$ Tandartsen zien bij ongedocumenteerde cliënten extreme situaties die niet meer voorkomen bij reguliere patiënten in Nederland. ${ }^{75}$

Mondverzorging is ook problematisch voor kinderen van ouders met een migratieachtergrond. ${ }^{76}$ Gebitsproblemen komen het meest voor bij kinderen van ouders met een migratieachtergond. Het Zorginstituut Nederland (ZiNL) concludeert dat jongeren met een migratieachtergrond zowel binnen de hoge als de lage SES-groep over het algemeen een slechter gebit hebben dan jongeren zonder een migratieachtergrond. De onderzoekers concluderen verder dat het hebben van een migratieachtergrond zeer bepalend is voor het voorkomen van cariës onder jeugdigen. ${ }^{77}$

Mensen met een migratieachtergond lopen extra risico op problemen met de mondgezondheid. Dit hangt samen met de al eerder geschetste leefomstandigheden van migranten. Er zijn risicofactoren voor een slechtere mondgezondheid en een kleiner aantal controlebezoeken aan de tandarts. Door een slechte mondverzorging en gebrek aan (preventieve) mondzorg kan een opeenstapeling van problemen ontstaan. Zo kan slechte mondgezondheid andere chronische aandoeningen versterken en kan een slecht gebit leiden tot psychische en maatschappelijk problemen. ${ }^{78} \mathrm{Er}$ zijn signalen dat veel patiënten zonder rechtmatig verblijf vaker en langere tijd klachten aan het gebit hebben dan volwassen Nederlandse burgers. ${ }^{79}$

\footnotetext{
${ }^{70}$ Rietveld e.a., $N T v G$ 2019;163:D3729.

${ }^{71}$ Mondgezondheid betreft volgens de Gezondheidsraad meer dan het niveau van het klinische, pathofysiologische beeld en de functionaliteit van de mond: het betreft ook het niveau van individueel functioneren en het niveau van het sociaal en maatschappelijk participeren, Gezondheidsraad 2012, p. 24. De Gezondheidsraad past het dynamische concept van gezondheid (zie $\S 2.2 .1$ ) dus toe op mondgezondheid.

${ }^{72}$ Gezondheidsraad 2012, p. 28.

${ }^{73}$ Gezondheidsraad 2012, p. 29.

${ }^{74}$ Dokters van de Wereld 2018, p. 52.

${ }^{75}$ Dokters van de Wereld 2018, p. 52.

${ }^{76}$ En ook voor kinderen van ouders met een lage SES, Dokters van de Wereld 2019, p. 7.

${ }^{77}$ Zorginstituut Nederland, Signalement mondzorg 2018, 19 november 2018, p. 5, zorginstituutnederland.nl.

${ }^{78}$ Dokters van de Wereld 2019, p. 4.

${ }^{79}$ Castelijns e.a., 2011, p. 21.
} 


\subsubsection{Vrouwen}

Er is weinig bekend over de algehele gezondheidstoestand van zwangere ongedocumenteerde vrouwen. Wel is in een onderzoek geconstateerd dat psychosociale problemen bij deze groep vrouwen vaker voorkomen. ${ }^{80}$

Volgens Schoevers is de ongedocumenteerde status op zichzelf een ziekmakende factor. ${ }^{81}$ Het gebruik van de gezondheidszorg onder deze groep vrouwen is laag. Vrouwen starten te laat met zwangerschapscontroles of krijgen deze in het geheel niet. Anticonceptie wordt weinig gebruikt, abortus provocatus wordt laat ondergaan en veel vrouwen hebben nooit een uitstrijkje of SOA-screening ondergaan. ${ }^{82}$ Het aantal ongewenste zwangerschappen onder ongedocumenteerde vrouwen ligt hoger dan bij Nederlandse vrouwen. ${ }^{83}$ Ongedocumenteerde vrouwen gaan later in hun zwangerschap naar de verloskundige dan Nederlandse vrouwen: vijf weken later dan reguliere migranten. ${ }^{84}$

Uit (beperkt) onderzoek is gebleken dat ongedocumenteerde vrouwen minder anticonceptie gebruiken dan Nederlandse vrouwen. Oorzaken daarvan zijn financiële redenen en gebrek aan informatie. ${ }^{85}$ Ook gaan zij vaker over tot abortus. ${ }^{86}$

\subsubsection{Kinderen}

Uit systematisch onderzoek blijkt dat vluchtelingenkinderen bij binnenkomst in de opvanglanden een hoge prevalentie hebben van (zowel 'gewone' als erfelijke) bloedarmoede, chronische hepatitis B, latente tuberculose-infectie en vitamine D-tekort. Ongeveer een derde van de kinderen had een darminfectie. ${ }^{87}$ De GGD doet bij binnenkomst in Nederland een intake waarbij hun gezondheid wordt gecheckt. Zij worden echter niet gescreend op psychosociale problemen. ${ }^{88}$

Langdurige bestaansonzekerheid, zoals een langdurige asielprocedure, leidt bij vluchtelingenkinderen tot ontwikkelingsschade. ${ }^{89}$ Ook de vele verhuizingen zijn schadelijk voor hun gezondheid..$^{90}$

Doordat veel ongedocumenteerde kinderen in armoede opgroeien, is er gebrek aan basale benodigdheden zoals gezonde voeding. Ook staan zij psychisch onder grote druk. ${ }^{91} \mathrm{Zij}$ hebben een grote kans dan ongedocumenteerde volwassenen op fysieke mishandeling, verwaarlozing, seksueel misbruik en psychisch geweld. ${ }^{92}$ Het verblijf in gezinslocaties heeft een negatieve impact op kinderen. Kinderen geven aan te kampen met veel gezondheidsklachten. Volgens de kinderen maken de inactiviteit, angst en stress de bewoners

\footnotetext{
${ }^{80}$ De Jonge e.a., Journal of Psychosomatic Obstetrics and Gynaecology 2011/4, p. 182-188.

${ }^{81}$ Schoevers 2011, p. 151.

${ }^{82}$ Schoevers 2011, p. 154.

${ }^{83}$ Schoevers 2011, p. 79.

${ }^{84}$ De Jonge e.a., Journal of Psychosomatic Obstetrics and Gynaecology, 2011/4, p. 182-188.

${ }^{85}$ Dokters van de Wereld 2018, p. 58.

${ }^{86}$ Dokters van de Wereld 2016, p. 48.

${ }^{87}$ Baauw e.a., BMJ Paediatrics Open 2019/3.

${ }^{88}$ Interview met tropen- en kinderarts A. Baauw in Augeomagazin juli 2016-2, augeomagazine.nl.

${ }^{89}$ Kalverboer \& Zijlstra, 2006.

${ }^{90}$ Interview met tropen- en kinderarts A. Baauw (supra noot 88).

${ }^{91}$ Kromhout e.a. 2014.

${ }^{92}$ Dokters van de Wereld 2016, p. 43.
} 
van de gezinslocatie ziek. Ze vertellen dat zij buik- en hoofdpijn hebben sinds ze in de gezinslocatie wonen. ${ }^{93}$ Volgens een meerderheid van de professionals en vrijwilligers in gezinslocaties is er onvoldoende aandacht is voor de geestelijke gezondheidszorg van kinderen. ${ }^{94}$

Kinderen lopen gezien hun geestelijke en lichamelijke onrijpheid extra risico op gezondheidsschade als gevolg van vreemdelingendetentie. ${ }^{95}$

\subsubsection{Geestelijke gezondheid}

Migratie wordt beschouwd als sociale determinant voor geestelijke gezondheid, in het bijzonder voor depressieve stoornissen gezien de associatie met stressvolle ervaringen die te maken hebben met verandering, verlies, waargenomen discriminatie en sociale marginalisering. ${ }^{96}$ Studies naar de geestelijke gezondheid van vluchtelingen tonen aan dat er sterk bewijs is voor een veel hogere prevalentie van geestelijke gezondheidsproblemen in verschillende landen van ontvangst, ongeacht de verblijfsstatus. ${ }^{97}$ De hypothese dat migranten een hoger percentage van depressieve symptomen melden dan niet-migranten is bevestigd in een studie, waarbij de prevalentie van depressieve symptomen tussen migranten ${ }^{98}$ en nietmigranten tussen 25-65 jaar oud in 21 Europese landen met elkaar werden vergeleken. In zeven van de onderzochte landen meldden migranten significant ernstiger depressieve symptomen, waarbij Nederland tot de landen behoort waarbij de verschillen het grootst zijn. ${ }^{99}$

Depressie en andere stoornissen zoals psychoses, angststoornissen en PTSS komen relatief vaker voor bij vluchtelingen. De langdurige postmigratie fase met bijbehorende onzekerheid kan een negatieve impact hebben op depressie en andere geestelijke gezondheidsproblemen. ${ }^{100}$ Riscofactoren voor de geestelijke gezondheid zijn onder meer de onzekerheid over de immigratie of vluchtelingenstatus, werkloosheid, verlies van sociale status en sociale uitsluiting. Deze risicofactoren spelen nog meer bij ongedocumenteerden. Onderzoek in Zwitserland laat zien dat het niet hebben van een verblijfsrecht psychische problematiek bevordert. ${ }^{101}$ Bij uitgeprocedeerde asielzoekers kunnen de opeengestapelde tegenslagen leiden tot een staat van demoralisatie, wat symbool staat voor het verlies van hoop. Demoralisatie heeft een grote impact op het geestelijk welbevinden. ${ }^{102}$ Volgens Lahuis e.a. is er weinig bekend over de geestelijke gezondheid van uitgeprocedeerde asielzoekers. Uit het onderzoek van

\footnotetext{
${ }^{93}$ Werkgroep kind in azc 2014, p. 38.

${ }^{94}$ Avance 2018, p. 35. Avance vermeldt dat dit een groot verschil is met de geestelijke gezondheidszorg in azc's.

95 Busser 2012.

${ }^{96}$ Gkiouleka e.a., European Journal of Public Health 2018/5, p 54-60.

${ }^{97}$ Lahuis e.a., European Journal of Psychotraumatology 2019, 10:1.

${ }^{98}$ Het onderzoek was niet specifiek gericht op vluchtelingen maar op migranten. Onder migrant werd verstaan iemand die ofwel in het buitenland geboren was ofwel die minimaal één ouder heeft die in het buitenland geboren was, Gkiouleka e.a., European Journal of Public Health 2018/5, p 54-60.

${ }^{99}$ Gkiouleka e.a., European Journal of Public Health 2018/5, p. 54-60. In minder dan de helft van de onderzochte landen klopte de hypothese, te weten in Zwitserland, Duitsland, Denemarken, Frankrijk, Nederland, Noorwegen, Polen en Zweden. In de rest van de onderzochte landen was er geen significant verschil, behalve in Griekenland en het Verenigd Koninkrijk.

${ }^{100}$ Kirmayer e.a., Canadian Medical Association Journal 2011/12, p. 959-967, Priebe e.a. 2016.

${ }^{101}$ Heeren e.a., Comprehensive Psychiatry 2014/4, p. 818-825.

${ }^{102}$ Lahuis e.a., European Journal of Psychotraumatology 2019, 10:1.
} 
Lahuis e.a. zijn de prevalentiecijfers voor (comorbide) ${ }^{103}$ geestelijke gezondheidsproblemen voor uitgeprocedeerde asielzoekers hoog. Deze groep kan worden beschouwd als een afzonderlijke populatie met unieke geestelijke gezondheidsproblemen en psychosociale behoeften. ${ }^{104}$

\subsection{Gebruik gezondheidszorg door irreguliere migranten}

\subsubsection{Kloof tussen aangeboden gezondheidszorg en gebruik}

Hebben alle migranten al issues met betrekking tot toegang tot gezondheidszorg, ongedocumenteerde migranten zijn extra kwetsbaar vanwege hun irreguliere status en economische en sociale marginalisatie. ${ }^{105}$ Studies over de zorg aan migranten in Europa laten zien dat irreguliere migranten weinig gebruik maken van de aangeboden gezondheidszorg in vergelijking tot migranten met papieren, ongeacht het systeem van aanspraken op zorg. ${ }^{106} \mathrm{De}$ kloof tussen het recht op gezondheidszorg en het daadwerkelijke gebruik ervan wordt in meerdere Europese studies benadrukt. ${ }^{107}$ Uit de studies blijkt dat irreguliere migranten het zoeken van hulp hadden vermeden of uitgesteld. Deze kloof is toe te schrijven aan meerdere factoren. In de sociaalwetenschappelijke literatuur wordt onderscheid gemaakt tussen formele en informele drempels met betrekking tot toegang tot de gezondheidszorg (zie paragraaf 1.3). ${ }^{108}$

Factoren die te maken hebben met gezondheidsbeleid en de organisatie van zorg (het systeem) kunnen formele barrières vormen. Dit is inclusief wettelijke beperkingen in de aanspraak op gezondheidszorgvoorzieningen voor bepaalde categorieën van migranten en de financiële barrières die van invloed kunnen zijn op migranten. Dit proefschrift ziet primair op deze formele barrières.

Informele drempels met betrekking tot de toegang tot de zorg worden onderverdeeld in factoren die te maken hebben met enerzijds de ongedocumenteerde zelf (gebrek aan kennis en administratieve vaardigheden, taal- en communicatieproblemen, gebrek aan sociaal netwerk, angst te worden aangegeven, culturele factoren en 'nieuwheid') en anderzijds de zorgaanbieders (interpretatie van 'medisch noodzakelijke zorg', onzekerheid over een naderend vertrek of uitzetting, en eveneens de taalbarrière en om kunnen gaan met culturele verschillen). Daarnaast zijn de gezondheidsvoorzieningen vaak niet voldoende om in etnisch gerelateerde gezondheidsbehoeften te voorzien, is de continuïteit van zorg vaak niet gegarandeerd, onder meer door het ontbreken van een vaste woon- en/of verblijfplaats en zijn er problemen met betrekking tot de overdracht van het medisch dossier. ${ }^{109}$ Data suggereren dat ongedocumenteerde migranten onvoldoende informatie over hun rechten hebben en vaak geen medische hulp zoeken uit angst te worden ontdekt. ${ }^{110}$

Het daadwerkelijke gebruik van de gezondheidszorg is niet alleen van belang voor de

\footnotetext{
${ }^{103}$ Comorbiditeit betekent het tegelijkertijd hebben van één of meerdere chronische aandoeningen naast de hoofddiagnose.

${ }^{104}$ Lahuis e.a., European Journal of Psychotraumatology 2019, 10:1.

105 De Vito e.a. 2015.

${ }^{106}$ Matlin e.a., Public Health Reviews 2018/27, Winters e.a., 2018, BMC Health Serv. Res. 2018/30.

107 PICUM 2016.

108 Onder meer Rechel e.a. 2011, p. 71-72, De Vito e.a. 2015.

${ }^{109}$ FRA 2011, p. 71 e.v.

${ }^{110}$ Rechel e.a., 2011.
} 
gezondheid van de migrant zelf maar kan ook leiden tot kostenbesparing. Uitkomsten van een studie van FRA die in drie Europese landen is uitgevoerd (voor twee situaties: hoge bloeddruk en prenatale zorg) suggereren dat structurele toegang tot preventieve gezondheidszorg voor ongedocumenteerde migranten, kostenbesparend is voor zorgsystemen in het land van verblijf. ${ }^{111}$

\subsubsection{Specifieke informele drempels}

\subsubsection{Huisartsenzorg}

In Nederland maken ongedocumenteerden vergeleken met de reguliere Nederlandse populatie minder frequent gebruik van huisartsenzorg. Extra problemen in de arts-patiëntrelatie kunnen ontstaan door miscommunicatie, als gevolg van taalbarrière, en een gebrek aan inlevingsvermogen van de zorgverlener in het 'culturele ziektebeeld' van de patiënt. Dit kan leiden tot patiënt delay, therapieontrouw, en chroniciteit van gezondheidsklachten. ${ }^{112}$

\subsubsection{Mondzorg}

Tandartsen kunnen op grond van de financieringsregeling ex artikel 122a Zvw alleen vergoeding krijgen voor zorg die onder de basisverzekering van de Zvw valt. Er wordt dientengevolge geen vergoeding verstrekt voor tandartsenzorg voor patiënten ouder dan 18 jaar (tot 1 januari 2011 ouder dan 21 jaar). Ook acute noodhulp valt niet onder de regeling. ${ }^{113}$ Voor mensen zonder rechtmatig verblijf zijn de rekeningen vaak te hoog om zelf te betalen. Daarnaast zijn er signalen dat veel tandartsen niet bereid zijn de zorg zonder betaling te verlenen. ${ }^{114}$

\subsubsection{Geestelijke gezondheidszorg}

Knelpunten bestaan er ook ten aanzien van de toegang tot de geestelijke gezondheidszorg voor irreguliere migranten. ${ }^{115}$ Priebe e.a. vatten de drempels waarmee vluchtelingen, asielzoekers en illegale migranten te maken krijgen bij de toegang tot geestelijke gezondheidszorg te maken krijgen als volgt samen: gebrek aan kennis van hun rechten op het gebied van gezondheidszorg en van de gezondheidszorgstelsels in het gastland; slechte beheersing van de taal van het gastland; geloofssystemen en culturele verwachtingen ten aanzien van de gezondheidszorg die verschillen van die in het gastland; en gebrek aan vertrouwen in professionals en autoriteiten. ${ }^{116}$

\footnotetext{
111 FRA 2015.

112 Dokters van de Wereld, 2016, p. 49. De conclusies uit dit onderzoek zijn gebaseerd op (institutionele en wetenschappelijke) literatuurstudie.

113 Doeleman, Nederlands Tandartsenblad 12 februari 2010. Tandartsen kunnen op grond van de financieringsregeling (zie hoofdstuk 4) alleen een bijdrage krijgen voor zorg die onder de basisverzekering van de Zvw valt: patiënten jonger dan 18 jaar, volledig uitneembare prothetische voorzieningen en bijzondere tandheelkunde. Zie verder par. 9.7.1 van dit proefschrift.

${ }^{114}$ Het probleem in toegang tot mondzorg is overigens niet exclusief voor ongedocumenteerden. Ook volwassen Nederlanders met een laag inkomen en thuis- en daklozen hebben problemen, zie onder meer Gezondheidsraad 2012 en Dokters van de Wereld 2019. De schatting is dat ruim een half miljoen mensen in Nederland om financiële redenen geen toegang hebben tot mondzorg, Dokters van de Wereld 2019, p. 5.

115 Achtergrondinformatie Dokters van de Wereld, ter gelegenheid van de rapportage 'Access to healthcare for vulnerable groups in the Europe in times of crises and rising xenophebia, an overview of the situation of people excluded form healthcare systems', 2012, Médecins du Monde en Wereldgezondheidsdag, april 2013.

${ }^{116}$ Priebe e.a. 2016, p. x (samenvatting).
} 
Teunissen e.a. noemen de irreguliere status van ongedocumenteerden op zichzelf als belangrijk obstakel in de toegang tot de geestelijke gezondheidszorg. Daarbij komen nog cultuur en taal als extra barrières om hulp te zoeken. Er lijkt een kloof te bestaan tussen de daadwerkelijke prevalentie van psychische klachten bij mensen zonder verblijfsstatus en de registratie van deze groep in medische patiëntendossiers. ${ }^{117}$ Het taboe en stigma rondom psychische problemen zullen een rol spelen bij deze groep, evenals het feit dat ongedocumenteerden andere prioriteiten hebben als zij zorg zoeken. Ook zijn zij wellicht onbekend met het feit dat zij met deze problemen naar de huisarts kunnen. ${ }^{118}$

GGZ-instellingen zijn onvoldoende geïnformeerd over de mogelijkheden om zorg te verlenen en/of stellen zich terughoudend op met het starten van een behandeling. Irreguliere migranten vinden het lastig om hulp te zoeken bij psychische klachten en ondervinden komen hier ook drempels tegen. ${ }^{119}$

\subsubsection{Infectieziekten}

De mate van toegankelijkheid van screening op infectieziekten hiv/AIDS, chlamydia, tbc en hepatitis $\mathrm{B}$ en $\mathrm{C}$ bij ongedocumenteerden ligt in Nederland hoger dan in andere EU-landen. ${ }^{120}$ Nederlandse huisartsen voeren relatief weinig testen uit op infectieziekten bij ongedocumenteerde patiënten. ${ }^{121}$ Het percentage van testen met positief resultaat (besmetting met hiv) ligt hoger onder ongedocumenteerden dan onder andere patiënten. ${ }^{122}$ Desondanks blijkt dat ongedocumenteerden relatief weinig worden getest. Zoals al eerder vermeld, zijn ongedocumenteerden extreem kwetsbaar als het gaat om risico op besmetting met COVID19. ${ }^{123}$ Uit angst voor sociaal isolement verzwijgen zij eventuele coronaklachten. Het is niet bekend hoeveel ongedocumenteerden op het coronavirus zijn getest. ${ }^{124}$

\subsubsection{Gezondheidsvaardigheden en hulpzoekgedrag}

Voor de toegang tot zorg zijn voorts de zogenoemde gezondheidsvaardigheden van belang. Dit zijn vaardigheden die nodig zijn om informatie over gezondheid te verkrijgen, begrijpen, beoordelen en te gebruiken bij het nemen van gezondheidsgerelateerde beslissingen. ${ }^{125}$ Hieronder valt het gebrek aan kennis over het recht op zorg, wat een grote barrière is in de toegankelijkheid van zorg voor ongedocumenteerden. Er bestaat angst voor hoge zorgkosten. $\mathrm{Zij}$ weten niet dat er een financiële regeling bestaat. Verder is er vaak sprake van een taalbarrière en gebrek aan assertiviteit en zijn er culturele verschillen en andere verwachtingen van zorg. ${ }^{126}$ Ook hebben ongedocumenteerden angst voor aangifte bij de politie doordat zij niet op de hoogte

\footnotetext{
117 Teunissen e.a., 2014, BMJ Open 2014;4:e005738.

118 Teunissen e.a., 2014, BMJ Open 2014;4:e005738.

119 Teunissen e.a., 2014, BMJ Open 2014;4:e005738.

${ }^{120}$ Chauvin \& Simonnot 2012.

${ }^{121}$ Wolswinkel e.a. 2009, p. 24.

122 Wolswinkel e.a. 2009, p. 24.

${ }^{123}$ PICUM Statement on COVID-19 pandemic, March 2020, picum.org, (laatst geraadpleegd 19 juni 2020).

$124 \mathrm{https} / / /$ nos.nl/nieuwsuur/artikel/2331805-illegalen-verzwijgen-coronaklachten-uit-angst-voor-isolatie.html (laatst geraadpleegd 13 augustus 2020).

125 Pharos 2016.

${ }^{126}$ Dokters van de Wereld 2019, p. 36.
} 
zijn van het beroepsgeheim. Dit kan leiden tot uitstel van een bezoek aan de hulpverlener. ${ }^{127}$ De toegang tot zorg waarvan de zorgkosten voor eigen rekening blijven, hangt in hoge mate af van het sociale netwerk, dat financieel bijspringt. ${ }^{128}$

Bij hulpzoekgedrag gaat het om factoren die invloed hebben op de mogelijkheid van ongedocumenteerden om een beroep te doen op zorg. Factoren zijn bijvoorbeeld leefomstandigheden, sociale steun en inkomen. ${ }^{129}$ Volgens het onderzoek van Rietveld lijkt het met de barrières in de toegankelijkheid van de zorg in Amsterdam mee te vallen. Een groot deel van de migranten zonder geldige verblijfsvergunning die vroegen om aanvullend onderdak, ontvingen al zorg. ${ }^{130}$

\subsubsection{Vrouwen}

Het gebruik van de gezondheidszorg onder ongedocumenteerde vrouwen is laag. Vrouwen starten te laat met zwangerschapscontroles of krijgen deze in het geheel niet. Anticonceptie wordt weinig gebruikt, abortus provocatus wordt laat ondergaan en veel vrouwen hebben nooit een uitstrijkje of SOA-screening ondergaan. ${ }^{131}$

Tijdens de bevalling hebben ongedocumenteerden ongeveer even vaak last van complicaties als migranten met een verblijfsvergunning. Verloskundigen ondervinden geen barrières bij een eventuele verwijzing naar de tweede lijn. Wel worden ongedocumenteerde vrouwen minder vaak verwezen naar de tweede lijn. Ongedocumenteerde vrouwen bevallen relatief vaker thuis. De toegang tot kraamzorg is vaak niet toereikend.

Verder worden ongedocumenteerde vrouwen niet opgeroepen voor deelname aan bevolkingsonderzoeken zoals die naar borst- en baarmoederhalskanker. De reden daarvan is dat zij niet ingeschreven staan in het Basisregistratie Personen (BRP).

\subsubsection{Kinderen}

De genoemde barrières in toegang tot zorg gelden ook voor ongedocumenteerde kinderen. Daarnaast verkeert deze groep in een extra afhankelijke positie. Als hun ouders drempels ervaren met betrekking tot de toegang tot zorg, kan dat doorwerken op de toegankelijkheid van zorg voor kinderen.

Uit een onderzoek van Pharos in 2010 bleek dat ongedocumenteerde kinderen en hun ouders slecht op de hoogte zijn van hun rechten en plichten ten aanzien van (de toegang tot) gezondheidszorg. ${ }^{132}$ Ouders stellen noodzakelijk ziekenhuisbezoek uit vanwege onbekendheid met de geheimhoudingsplicht van artsen. Er heerst veel angst bij ongedocumenteerden.

Daarnaast kan de overdracht van medische dossiers bij verhuizingen en wijzigingen in status zorgen voor discontinuïteit in de zorg. Zo schoot de overdracht van medische informatie van een asielzoekerscentrum (azc) naar een detentiecentrum ernstig tekort in de casus van de zesjarige Renata A., bij wie de diagnose acute leukemie door de zorgverleners in Nederland

\footnotetext{
127 Straßmayr e.a., BMC Public Health 2012;12:367.

${ }^{128}$ Pharos 2019, p. 11.

${ }^{129}$ Dokters van de Wereld 2019, p. 35.

${ }^{130}$ Rietveld e.a., $N T v G$ 2019;163:D3729.

${ }^{131}$ Schoevers e.a., International Journal of Public Health 2010/55, p. 421-428.

132 Pharos 2010.
} 
niet werd vastgesteld. ${ }^{133}$ Het meisje overleed kort na uitzetting naar Polen, dat op grond van de EU-Dublinverordening verantwoordelijk was voor afhandeling van het asielverzoek van het gezin. ${ }^{134}$

Sommige kinderen worden niet preventief gevaccineerd omdat het woonadres onbekend is. ${ }^{135}$ Kinderen in gezinslocaties ervaren het als lastig om toegang te krijgen tot de huisarts of tweedelijns zorg. Ze geven aan behoefte te hebben aan zorg die beter toegankelijk is en die meer oog en oor heeft voor hun (specifieke) situatie en behoeften. ${ }^{136}$

\subsection{Conclusie}

De Vreemdelingenwet regelt wanneer een vreemdeling rechtmatig in Nederland verblijft. Doet hij dat niet, dan verblijft hij onrechtmatig. Onrechtmatig verblijf kan door meerdere oorzaken ontstaan. Eén daarvan is de situatie waarin een uitgeprocedeerde asielzoeker in Nederland is gebleven.

De irreguliere migrant is - over het algemeen - geen 'gewone' patiënt. Zowel de migratie als de juridische status van ongedocumenteerden vormen determinanten voor de gezondheid net zoals voor de toegankelijkheid van zorg. Migranten hebben te maken met het 'healthy migrant effect'. De gezondheid neemt niet toe, maar af na aankomst in een gastland. Postmigratiestressfactoren vormen een risico voor psychische ziekten. Dit wordt versterkt door langdurig verblijf in een azc. Daarnaast heeft de irreguliere migrant te maken met sociale determinanten voor de gezondheid. Uit angst om te worden aangegeven, zal de ongedocumenteerde minder snel een beroep doen op medische zorg. Zijn migranten op zichzelf al kwetsbaar, binnen deze groep bevinden zich ook nog extra kwetsbare patiënten zoals vrouwen, kinderen en mensen met geestelijke gezondheidsproblemen. Kinderen zijn daarbij extra afhankelijk. Ongedocumenteerde migranten hebben een verhoogd risico op gezondheidsproblemen. Gezondheidsschade kan voorts worden opgelopen door verblijf in vreemdelingendetentie. De toegang tot zorg wordt beperkt door formele en informele drempels. Een aantal informele drempels is beschreven. Hieruit blijkt dat een ongedocumenteerde doorgaans al één of meerdere hobbels heeft overwonnen vóórdat hij zich tot een zorgverlener wendt. Bij de beschrijving van de juridische problematiek is het goed om voor ogen te houden dat deze feitelijke problemen zich onder de oppervlakte bevinden. De informele drempels geven reden voor extra bescherming van de irreguliere migrant vanuit gezondheidsrechtelijk perspectief.

\footnotetext{
${ }^{133}$ IGJ en IVenJ 2017. De inspecties concludeerden dat in deze zaak de verslaglegging door betrokken partijen onzorgvuldig en onvolledig was en dat er sprake was van gebrekkige uitwisseling van medische gegevens.

${ }^{134}$ De Dublin III-verordening bepaalt dat een asielzoekers slechts in één land asiel mag aanvragen. Als uit onderzoek blijkt dat een ander land dan Nederland verantwoordelijk is voor een asielverzoek, dan wordt het asielverzoek in Nederland afgewezen en dient de IND een verzoek om overdracht bij het andere land in.

135 Dokters van de Wereld 2016, p. 50.

${ }^{136}$ Werkgroep Kind in azc, 2014, p. 38-41.
} 


\title{
Hoofdstuk 3 Medische zorg aan vreemdelingen zonder rechtmatig verblijf: achtergrond wettelijke regeling
}

\author{
In 2013 diende de regering Rutte-II een \\ wetsvoorstel in waarmee werd beoogd om illegaal \\ verblijf strafbaar in Nederland te stellen \\ (Kamerstukken II 2012/13, 33 512, nr. 1). Doel van \\ het wetsvoorstel was om de toestroom van \\ vreemdelingen te beperken en illegaal verblijf te \\ voorkomen en te bestrijden. Illegaal verblijf zou \\ worden bestraft met een hechtenis van ten \\ hoogste vier maanden of een geldboete van de \\ tweede categorie, ten hoogste $€ 3900,-$. Wel \\ zouden illegalen in Nederland recht houden op \\ medisch noodzakelijke zorg en hun kinderen recht \\ op onderwijs. Het wetsvoorstel werd na de \\ verkiezingen in 2014 ingetrokken, mede vanwege \\ kritiek uit de samenleving.
}

\subsection{Inleiding}

$\mathrm{Na}$ de verkenning van het onderwerp in het vorige hoofdstuk, sla ik nu af naar de juridische hoofdweg. Om te kunnen begrijpen hoe het systeem van financiering van medisch noodzakelijke zorg aan vreemdelingen zonder rechtmatig verblijf is vormgegeven, is een analyse van de onderliggende grondslag noodzakelijk. Deze bestaat uit de in 1998 in werking getreden Koppelingswet, die de aanspraak op collectieve voorzieningen - waaronder de (sociale) ziektekostenverzekeringen - koppelt aan de verblijfsstatus van de vreemdeling. De parlementaire geschiedenis van deze omstreden wet, specifiek de discussie over de vormgeving voor de financiering van medisch noodzakelijke zorg van vreemdelingen, staat in dit hoofdstuk centraal. Doel van het hoofdstuk is primair het geven van inzicht in zowel de motieven van de wetgever om de Koppelingswet in te voeren als de overwegingen die ten grondslag hebben gelegen aan het opnemen van de uitzondering 'medisch noodzakelijke zorg' in deze wet. Secundair wordt onderzocht op welke (gezondheidsrechtelijke) kritiek de Koppelingswet is gestuit. In hoofdstuk acht kom ik terug op deze kritiek. 


\subsection{Achtergrond Koppelingswet}

\subsubsection{Vreemdelingenbeleid}

De Koppelingswet maakt onderdeel uit van het vreemdelingenbeleid. Vanaf de jaren zestig van de vorige eeuw ontwikkelde zich een steeds restrictiever vreemdelingenbeleid. ${ }^{1}$ De tolerantie jegens ongedocumenteerden nam af, maar toch werd - ingegeven door economische belangen - illegaal verblijf gedoogd. Er kwam steeds meer aandacht voor illegale vreemdelingen en de mogelijkheden om hen te laten terugkeren naar hun land van herkomst. ${ }^{2}$ Sinds het begin van de jaren 90 van de vorige eeuw worden illegale vreemdelingen steeds meer als een 'sociaal probleem' beschouwd, in de zin van een bedreiging voor economie en maatschappij. ${ }^{3}$ Met als startpunt het advies van de commissie Binnenlands Vreemdelingentoezicht (hierna: de commissie Zeevalking $)^{4}$ richtte het vreemdelingenbeleid zich op het effectief bestrijden van illegaal verblijf. De herziening van de Vreemdelingenwet 1964 leidde tot de Vreemdelingenwet 2000 (Vw). Door uitsluiting van arbeid en publieke voorzieningen was het beleid erop gericht om illegaal verblijf effectief te bestrijden. Sluitstuk van dit beleid is de Koppelingswet. ${ }^{5}$ Sinds 2005 is sprake van een restrictief overheidsbeleid met weinig tot geen tolerantie ten aanzien van ongedocumenteerden. ${ }^{6}$ Ook het maatschappelijk ongenoegen over ongedocumenteerden nam toe. Toen in 2013 het wetsvoorstel strafbaarstelling illegaliteit aanhangig was, bleek uit een peiling dat meer dan de helft van de Nederlandse bevolking voor strafbaarstelling was. ${ }^{7}$

\subsubsection{Korte inhoud en doel Koppelingswet}

De Koppelingswet is een verzamelwet die 26 materiewetten op het gebied van onderwijs, sociale zekerheid, huisvesting en gezondheidszorg wijzigde. De Koppelingswet positiveerde op deze gebieden het koppelingsbeginsel. Dit beginsel koppelt zoals gezegd de aanspraak op collectieve voorzieningen aan het rechtmatig verblijf van de aanvrager. ${ }^{8}$ Het begrip 'rechtmatig verblijf' uit de Vw is daarbij bepalend (zie paragraaf 2.2.3.2).

De twee doeleinden van het koppelingsbeginsel (en dus van de Koppelingswet) zijn volgens de memorie van toelichting (MvT) tweeledig:

1. Het voorkómen dat mensen zonder rechtmatig verblijf door het krijgen van uitkeringen en voorzieningen in staat worden gesteld tot voortzetting van hun verblijf.

2. Het voorkómen dat mensen zonder rechtmatig verblijf een schijn van volkomen legaliteit kunnen verwerven. ${ }^{9}$

\footnotetext{
${ }^{1}$ Tot de jaren zestig was in Nederland sprake van tolerantie jegens de toelating van spontane arbeiders die in die tijd meestal afkomstig waren uit het Middellandse Zeegebied. Dit hing samen met de grote behoefte aan laaggeschoolde arbeidskrachten, Engbersen \& Burgers 1999 p. 1.

${ }^{2}$ WODC Evaluatie Vreemdelingenwet 2000, p. 25.

${ }^{3}$ Engbersen \& Burgers 1999, p. 3.

${ }^{4}$ Commissie Zeevalking 1991 (zie par. 3.2.3.2 van dit proefschrift).

${ }^{5}$ Kamerstukken II 1994/95, 24 233, nr. 3, p. 4.

${ }^{6}$ Oostveen 2018, p. 32.

7 'Meerderheid wil illegaal verblijf strafbaar stellen', Trouw 2 maart 2014.

${ }^{8}$ Vanwege de koppeling tussen diverse administratiebestanden werd het koppelingsbeginsel ook wel (ten onrechte) uitgelegd als de koppeling tussen de vreemdelingenadministratie en de administratie van de uitkerende/verstrekkende instanties.

${ }^{9}$ Kamerstukken II 1994/95, 24 233, nr. 3, p. 1-2.
} 
Het koppelingsbeginsel als zodanig is wettelijk verankerd in artikel 10 lid $1 \mathrm{Vw}$ : de vreemdeling die geen rechtmatig verblijf heeft, kan geen aanspraak maken op toekenning van verstrekkingen, voorzieningen en uitkeringen bij wege van een beschikking van een bestuursorgaan. Wanneer sprake is van rechtmatig verblijf, wordt bepaald in artikel $8 \mathrm{Vw} .{ }^{10}$ Het moet gaan om verstrekkingen, uitkeringen, voorzieningen, vergunningen en ontheffingen waarop aanspraak op grond van een wetsvoorschrift zou kunnen worden gemaakt. Zo is er, aldus de MvT, als de vreemdeling zich bij een openbaar ziekenhuis meldt om zich daar geneeskundig te laten behandelen louter sprake van feitelijk handelen en niet van een voorziening die bij overheidsbeschikking wordt geboden. ${ }^{11}$

De Koppelingswet kent vier uitzonderingen op het koppelingsbeginsel, te weten indien de aanspraak betrekking heeft op 1. het onderwijs, 2. de verlening van medisch noodzakelijke zorg, 3. de voorkoming van inbreuken op de volksgezondheid, of 4. de rechtsbijstand aan de vreemdeling (artikel 10 lid $2 \mathrm{Vw}$ ). Deze voorzieningen komen ten laste van de collectieve middelen, ook als er geen verblijfstitel is.

Artikel 11 lid 1 Vw bepaalt dat de aanspraken van de vreemdeling die rechtmatig verblijf heeft in overeenstemming zijn met de aard van het verblijf. De vreemdeling heeft meer aanspraken naarmate zijn verblijfsrecht sterker is. Dit wordt verder uitgewerkt in artikel 11 lid $2 \mathrm{Vw}$ waarin een onderscheid wordt gemaakt tussen vreemdelingen die onvoorwaardelijk tot Nederland zijn toegelaten (rechtmatig verblijf op grond van artikel 8, onder a t/m e en $1 \mathrm{Vw}$ ) en vreemdelingen die dat (nog) niet zijn. ${ }^{12}$ Kan de eerste categorie onvoorwaardelijk en op gelijke wijze als Nederlanders aanspraak maken op toekenning van voorzieningen, verstrekkingen en uitkeringen, de tweede categorie vreemdelingen heeft alleen aanspraak op voorzieningen voor zover dat uitdrukkelijk in een wet is neergelegd. Samengevat kunnen als hoofdregel alleen vreemdelingen met een verblijfsvergunning voor bepaalde of onbepaalde tijd aanspraak maken op collectieve voorzieningen. ${ }^{13}$

Een bijzondere vorm van het koppelingsbeginsel is het zogenoemde doorkoppelingsbeginsel. Dit koppelingsbeginsel is neergelegd in de Algemene wet inkomensafhankelijke regelingen (Awir, artikel 9, tweede en derde lid) en houdt in dat geen huurtoeslag, zorgtoeslag en kindgebonden budget wordt verstrekt aan Nederlanders of rechtmatig in Nederland verblijvende vreemdelingen, indien de partner of medebewoner geen rechtmatig verblijf heeft. ${ }^{14}$

\subsubsection{Voorgeschiedenis Koppelingswet}

\subsubsection{Jaren '80 vorige eeuw: de kiem werd gelegd}

\footnotetext{
${ }^{10}$ Zie par. 2.2.3.2 van dit proefschrift.

${ }^{11}$ Kamerstukken II 1994/95, 24 233, nr. 3, p. 14-15.

12 Zie par. 3.3.2.3 van dit proefschrift.

${ }^{13}$ Zwaan e.a. 2020, p. 407.

14 Zo genoemd in ABRvS 20 februari 2019, ECLI:NL:RVS:2019:515 en ABRvS 29 februari 2019, ECLI:NL:RVS:2019:62. Het in art. 9 tweede en derde 3 Awir neergelegde koppelingsbeginsel dient ertoe te voorkomen dat niet rechtmatig in Nederland verblijvende partners of medebewoners zouden kunnen meeprofiteren van de tegemoetkomingen die aan de Nederlander worden toegekend.
} 
In de jaren tachtig van de vorige eeuw werd het vreemdelingenbeleid - zoals hierboven gezegd - steeds bepalender voor de aanspraak op overheidsvoorzieningen. ${ }^{15}$ In 1979 werd voor het eerst met de gedachte gespeeld om bij uitkeringen op grond van de sociale verzekeringswetten betekenis toe te kennen aan de verblijfsrechtelijke status. ${ }^{16}$ Dit werd echter niet opgepakt totdat de Commissie Geelhoed in 1984 adviseerde om illegaal verblijvende vreemdelingen uit te sluiten van gefinancierde rechtshulp. ${ }^{17}$ De discussie werd voortgezet in het in 1985 verschenen 'eindrapport heroverweging uitvoering vreemdelingenwetgeving'. ${ }^{18}$ Hierin beval de Heroverwegingscommissie aan om bij de regelgeving en uitvoering op het punt van maatschappelijke voorzieningen zoveel mogelijk te waarborgen dat illegale vreemdelingen van deze voorzieningen worden uitgesloten. Hierbij was bezuinigen het doel. Dit vormde aanleiding voor de ministerraad om advies te vragen aan de Interdepartementale Commissie Minderhedenbeleid. Na het gegeven - niet openbare ${ }^{19}$ - advies luidde het uitgangspunt van het kabinet dat 'vreemdelingen die op illegale wijze in Nederland verblijven geen recht kunnen doen gelden op maatschappelijke voorzieningen, tenzij internationale verplichtingen, (grond-)wettelijke verplichtingen, (klemmende) humanitaire overwegingen of redenen ontleend aan het belang van de volksgezondheid hiertoe nopen.' Volgens de ministerraad voldeed het toenmalige overheidsbeleid grotendeels en steeds meer aan dit uitgangspunt. ${ }^{20}$ In de Notitie herziening vreemdelingenwetgeving uit 1986 werd de uitsluiting van illegale vreemdelingen voor het eerst in verband gebracht met het toezicht op vreemdelingen. ${ }^{21}$ Doordat effectief toezicht op illegaliteit niet meer mogelijk was, diende de overheid te zoeken naar nieuwe wegen om het restrictief vreemdelingenbeleid te handhaven. Eén van deze nieuwe wegen was de opsporing verplaatsen naar het loket van (semi)overheidsinstanties. ${ }^{22}$

\subsubsection{Jaren '90: totstandkoming Koppelingswet}

Vanaf begin jaren negentig van de vorige eeuw werden maatregelen ingevoerd om misbruik en onrechtmatig verblijf in Nederland te ontmoedigen. Voorbeelden hiervan zijn de invoering van verschillende identificatieplichten en het uitsluitend verstrekken van een sociaalfiscaal nummer aan verblijfsgerechtigden.

Het koppelingsbeginsel werd voor het eerst gehanteerd in een motie van Krajenbrink en Wiebenga, waarin werd aangedrongen op consequent overheidsbeleid met betrekking tot verstrekkingen ten laste van de collectieve middelen aan hen die onrechtmatig in Nederland verblijven. ${ }^{23}$ De directe aanleiding tot de Koppelingswet vormt de centrale aanbeveling van de

\footnotetext{
${ }^{15}$ Simon, NJB 1987/14, p. 429-434.

${ }^{16}$ Rapport 'Illegale arbeid door vreemdelingen', Kamerstukken II 1979/80, 16 012, nr. 2. Vgl. Simon, NJB $1987 / 14$, p. 429.

${ }^{17}$ Eindbericht van de Commissie vermindering en vereenvoudiging van overheidsregelingen, Kamerstukken II 1983/84, 17 931, nr. 9.

18 Heroverweging van overheidstaken, vierde ronde, Uitvoering vreemdelingenwetgeving, Kamerstukken II 1985/86, 16 625, nrs. 77-78.

${ }^{19}$ Aldus Simon, NJB 1987/14, p. 429-434.

${ }^{20}$ Kamerstukken II 1985/86, nr. 923.

${ }^{21}$ Simon, NJB 1987/14, p. 429-434.

${ }^{22}$ Simon, NJB 1987/14, p. 429-434.

${ }^{23}$ Kamerstukken II 1992/93, 22 981, nr. 1, p. 3. De motie hield in dat a. slechts diegenen recht hebben op gebruik van bepaalde overheidsvoorzieningen die aan de verblijfsvoorwaarden daartoe voldoen; $b$. de controle op de legaliteit van het verblijf zal geschieden in het kader van de bevolkingsadministratie.
} 
commissie Zeevalking om de aanspraak op collectieve voorzieningen te koppelen aan het verblijfsrecht van de betrokkene. ${ }^{24}$ De commissie kwam tot de centrale aanbeveling dat illegalen in beginsel uitgesloten dienen te worden van collectieve voorzieningen, teneinde illegaal verblijf tegen te gaan. 'In beginsel', omdat de uitsluiting volgens de commissie wel doelmatig diende te zijn en geen belangrijke neveneffecten mocht opleveren voor leden van minderheidsgroepen. Verder achtte de commissie verstrekking van collectieve voorzieningen noodzakelijk in gevallen waarin de vreemdeling zich in een acute noodsituatie bevindt, of in gevallen waarbij zwaarwegende Nederlandse belangen, respectievelijk internationale verplichtingen in het geding zijn. Onder 'acute noodsituatie' verstond de commissie 'een plotseling opkomende omstandigheid, in de tijd sterk gelimiteerd, die de verstrekking van de voorziening essentieel maakt voor de psychische, fysieke of economische gesteldheid van de vreemdeling'. ${ }^{25}$ Bij 'zwaarwegende Nederlandse belangen' dacht de commissie vooral aan de gezondheidszorg. De commissie achtte een goede toegankelijkheid van de gezondheidszorg voor een ieder die in Nederland verblijft een zwaarwegend Nederlands belang in het kader van preventie van besmettelijke ziektes en bij de drugsbestrijding. ${ }^{26}$

Van misbruik van collectieve voorzieningen door illegalen was de commissie niets gebleken en dat lag dan ook uitdrukkelijk niet aan de uitsluiting ten grondslag. Het ging erom dat de illegaal niet onbedoeld door of vanwege de overheid in staat kan worden gesteld in Nederland te verblijven. ${ }^{27}$ Ook de regering achtte het feitelijk gebruik van collectieve voorzieningen door mensen zonder rechtmatig verblijf van secundair belang. Voorop stond dat het voor een niet verblijfsgerechtigde vreemdeling onmogelijk zou worden zich met behulp van collectieve voorzieningen staande te houden in de Nederlandse samenleving. Hierdoor zou de vreemdeling in staat worden gesteld zijn wederrechtelijk verblijf voort te zetten en zou het moeilijker worden de vreemdeling, die de mogelijkheid krijgt in te burgeren, uit te zetten. ${ }^{28}$

Uitgangspunt van het principe van geïntegreerd vreemdelingenbeleid is dat een vreemdeling, die in Nederland wil verblijven, toelating dient aan te vragen. Wie niet wordt toegelaten, dient Nederland onverwijld te verlaten (zogenoemde vertrekplicht). De overheid achtte met dit principe onverenigbaar dat de vertrekplichtige vreemdeling niettemin uitkeringen, ontheffingen, verstrekkingen en voorzieningen zou kunnen krijgen. ${ }^{29}$ De Raad van State (RvS) wees er in haar advies over de Koppelingswet op dat de overheid, die niet tot uitzetting overgaat, zich niet aan elke verantwoordelijkheid kan onttrekken. ${ }^{30}$ De regering onderschreef dit, maar betwistte principieel dat deze verantwoordelijkheid zou berusten op nietuitzetting. De vreemdeling kan geen rechten ontlenen aan het feit dat de overheid feitelijke verwijdering nalaat. Met de wettelijke verankering van het koppelingsbeginsel zou het voorzieningenbeleid het vreemdelingenbeleid niet meer kunnen doorkruisen. ${ }^{31}$ De regering rechtvaardigde het koppelingsbeginsel door het principe van 'eigen schuld': iemand die

\footnotetext{
${ }^{24}$ Commissie Zeevalking 1991.

${ }^{25}$ Commissie Zeevalking 1991, p. 20 (par. 12).

${ }^{26}$ Commissie Zeevalking 1991, p. 20-21 (par. 13)

${ }^{27}$ Commissie Zeevalking 1991, p. 18 (par. 3).

${ }^{28}$ Onder meer Kamerstukken II 1994/95, 24 233, nr. 3, p. 4, Kamerstukken II 1995/96, 24 233, nr. 6, p. 2.

${ }^{29}$ Kamerstukken II 1995/96, 24 233, nr. 4, p. 2.

${ }^{30}$ Kamerstukken II 1994/95, 24233 A, p. 3.

${ }^{31}$ Kamerstukken II 1995/96, 24 233, nr. 6, p. 15.
} 
Nederland niet uit eigen beweging verlaat, heeft de hieruit voortvloeiende problemen in beginsel aan zichzelf te wijten. ${ }^{32}$

De uitvoerige parlementaire behandeling van de Koppelingswet duurde ruim zes jaar. Het wetsvoorstel is daarbij nog enkele keren fundamenteel gewijzigd. Eén van deze wijzigingen betrof de categorieën vreemdelingen die onder de Koppelingswet vallen. ${ }^{33}$

\subsubsection{Verschillende categorië̈n vreemdelingen}

Het aanvankelijke wetsvoorstel Koppelingswet bepaalde dat alleen onvoorwaardelijk toegelaten vreemdelingen aanspraak konden maken op collectieve voorzieningen. ${ }^{34}$ Dat wil zeggen vreemdelingen die op basis van artikel $9 \mathrm{Vw}$ (oud) een verblijfsvergunning hadden gekregen of die op basis van artikel $10 \mathrm{Vw}$ (oud) onbepaald toegelaten waren. ${ }^{35}$ Dit stuitte op veel kritiek, wat leidde tot herformulering van het beginsel. De regering koos voor een categorale uitsluiting van onrechtmatig verblijvende vreemdelingen. De categorische uitsluiting van rechtmatig verblijvende vreemdelingen werd geschrapt, omdat deze uitsluiting geen recht deed aan het recht op minimale voorzieningen van (nog) niet onvoorwaardelijk toegelaten vreemdelingen. ${ }^{36}$

De regering wenste in overeenstemming met de aanbeveling van de commissie Zeevalking differentiatie te kunnen aanbrengen naar verblijfsstatus. Vreemdelingen die een onvoorwaardelijk verblijfsrecht hebben, konden volgens de regering meer aanspraken doen gelden dan vreemdelingen met een voorwaardelijk verblijfsrecht. ${ }^{37}$ Voor deze toegelaten vreemdelingen geldt dat de overheid instemt met hun bestendig verblijf in Nederland.

Het huidige artikel 11 lid $2 \mathrm{Vw}$ bevat de criteria voor de differentiatie in de aanspraken van vreemdelingen die rechtmatig in Nederland verblijven. De feitelijke toekenning van aanspraken is in de betreffende materiewetten geregeld. ${ }^{38}$

\subsubsection{Principiële kritiek op de Koppelingswet}

De wetgever achtte de Koppelingswet volkomen in overeenstemming met alle verdragen die waarborgnormen zouden kunnen bevatten voor onrechtmatig verblijvende vreemdelingen. ${ }^{39}$ In de literatuur werd (en wordt) hier anders over gedacht. Op de Koppelingswet als zodanig is veel kritiek geweest van uiteenlopende aard. Eén van de belangrijkste kritiekpunten betreft de mogelijke disproportionaliteit van de Koppelingswet. Zowel tijdens de parlementaire behandeling van de wet als in de literatuur werd de vraag gesteld in hoeverre de middelen van de Koppelingswet in verhouding staan tot het doel: het bestrijden van illegaal verblijf. ${ }^{40}$

Daarnaast werd aangevoerd dat de Koppelingswet in strijd zou zijn met de in

\footnotetext{
${ }^{32}$ Kamerstukken II 1994/95, 24 233, nr. 3, p. 4.

${ }^{33}$ Portegies-Damave, AA 1998/9, p. 768-778.

${ }^{34}$ Kamerstukken II 1994/95, 24 233, nr. 2.

${ }^{35}$ Kamerstukken II 1994/95, 24 233, nr. 3, p. 11.

${ }^{36}$ Kamerstukken II 1995/96, 24 233, nr. 7, p. 9.

${ }^{37}$ Kamerstukken II 1995/96, 24 233, nr. 6, p. 3.

${ }^{38}$ Zie hoofdstuk 4 voor de bespreking van de wettelijke verankering in de (sociale) zorgverzekeringen.

${ }^{39}$ Kamerstukken II 1994/95, 24233 A, p. 5.

${ }^{40}$ Onder meer Kamerstukken II 1995/96, 24 233, nr. 6, p. 20, Schermers NJB 1996/2, p. 247, Gevers, TvGR 1996/3, p. 121, Hendriks, Migrantenrecht 1996/3, p. 51-56, Minderhoud, AA 1998/9, p. 775-778, NJCM 1999.
} 
internationale verdragen en in de Grondwet verankerde grond- en mensenrechten zoals het discriminatieverbod. ${ }^{41}$ De Koppelingswet zou voorts een aantal ongewenste nadelige effecten hebben voor onrechtmatige migranten, zoals het ondergronds drijven van deze groep en het afschrikken van onrechtmatige migranten om hun rechten te effectueren. ${ }^{42}$ Ook zou er een met de Verenigde Staten vergelijkbare ontwikkeling kunnen ontstaan, te weten vijandigheid jegens en discriminatie van migranten en angst onder migrantengroepen. ${ }^{43}$

\subsection{Uitwerking koppelingsbeginsel voor de gezondheidszorg}

\subsubsection{Aanspraak op ziektekostenverzekeringen vóór de Koppelingswet}

Vóórdat de Koppelingswet in werking trad, bestond aanspraak op collectieve voorzieningen, zoals een bijstandsuitkering, huursubsidie en ziektekostenverzekering ongeacht de verblijfsstatus van de persoon. Wie aan de in de wet gestelde voorwaarden voor verzekering voldeed, was van rechtswege verzekerd. Vreemdelingen zonder rechtmatig verblijf konden dan ook verzekerd zijn via de sociale ziektekostenverzekeringen. In het stelsel vóór 2006 ging dat om de Ziekenfondswet (Zfw), de Algemene Wet Bijzondere Ziektekosten (AWBZ) en de Wet op de toegang tot ziektekostenverzekeringen (Wtz). ${ }^{44}$ Voor de verzekeringsplicht ingevolge de sociale ziektekostenverzekeringen was dit het geval indien de vreemdeling in dienstbetrekking werkte en loonbelasting betaalde of indien de vreemdeling een verzekeringsplichtige uitkering dan wel een bijstandsuitkering ontving. De verzekeringsplicht van de AWBZ gold voor ingezetenen van Nederland, of voor niet-ingezetenen voor zover men in dienstbetrekking werkte en aan loonbelasting was onderworpen. Destijds was het voor illegalen mogelijk om formeel werkzaam te zijn in bepaalde sectoren van de arbeidsmarkt, op basis waarvan een sofinummer kon worden verkregen. ${ }^{45}$ Indien de vreemdeling niet verzekerd was, werden de ziektekosten ook wel betaald ten laste van de Algemene bijstandswet (Abw, nu: Participatiewet). Op grond van de Abw was het mogelijk om vreemdelingen bijstand te verlenen wegens zeer dringende redenen (via de gemeentelijke sociale dienst). ${ }^{46}$ Ook kwam het voor dat mensen zonder rechtmatig verblijf gebruik makkten van andermans verzekeringspapieren. De kosten van preventieve gezondheidszorg werden gefinancierd ten laste van de rijksbegroting. ${ }^{47}$

Zowel vanuit particulier initiatief - zoals de charitatieve polikliniek Kruispost en de Witte Jas (beide te Amsterdam) - als vanuit de gevoelde noodzaak om gezondheidszorg aan illegalen te leveren, was sprake van een functionerend systeem van maatschappelijke regelingen voor de gezondheidszorg aan illegalen. ${ }^{48}$

\footnotetext{
${ }^{41}$ Schermers, NJB 1996/2, p. 247, Toebes, Migrantenrecht 1996/3, p. 197-199, Gevers, TvGR 1996/3, p. 121, Hendriks, Migrantenrecht 1996/3, p. 51-56. Over het uitsluiten van niet rechtmatig in Nederland verblijvende vreemdelingen van (semi)-overheidsvoorzieningen in algemene zin zij verwezen naar Simon, NJB 1987/14, p. 429-434.

${ }^{42}$ Bernini en Engbersen, NJB 1999/2, p. 65-71.

${ }^{43}$ Minderhoud 1998, $A A$ 1998/9, p. 775-778.

${ }^{44}$ Tweederde deel van de bevolking was verplicht verzekerd op grond van de Zfw, overige ingezetenen konden zich verzekeren via particuliere ziektekostenverzekeringen. Leenen e.a. 2017, p. 647. Voor de beschrijving van het nieuwe stelsel: zie par. 4.2.1.

${ }^{45}$ Engbersen e.a. 2002 , p. 5.

46 Art. 10 jo 84 lid 1 Abw (oud).

${ }^{47}$ Kamerstukken II 1994/95, 24 233, nr. 3, p. 23.

${ }^{48}$ NRV 1995, p. 5.
} 
Het was niet bekend hoe hoog de kosten van de verschillende betalingsmogelijkheden voor illegaal verblijvende vreemdelingen waren. Bekend was wel dat het feitelijk gebruik van de gezondheidszorg van deze groep beperkt van omvang was. ${ }^{49}$ Volgens De Groot moest de omvang van de hulp aan onverzekerde illegalen echter niet worden onderschat. De gemeente Amsterdam bijvoorbeeld verstrekte jaarlijks drie tot vijf miljoen gulden (circa 1.4 tot 2.3 miljoen euro, VD) aan onverzekerden in het kader van de bijzondere Bijstand. De totale kosten van de gezondheidszorg aan illegalen in Amsterdam werd op tien tot vijftien miljoen gulden per jaar begroot (circa 4.5 tot 6.8 miljoen euro, VD). ${ }^{50}$

\subsubsection{Advies Ziekenfondsraad 1992}

Op verzoek van de toenmalige Staatssecretaris van Welzijn, Volksgezondheid en Cultuur (WVC) bracht de Ziekenfondsraad in 1992 een advies uit over de sociale ziektekostenverzekeringsaspecten van het kabinetsvoornemen om illegaal in Nederland verblijvende vreemdelingen in beginsel van collectieve voorzieningen uit te sluiten. ${ }^{51} \mathrm{De}$ initiële bedoeling van het kabinet was om uitsluiten van illegale vreemdelingen van collectieve voorzieningen te verwezenlijken door vreemdelingen zonder rechtmatig verblijf wel verzekerd te laten voor sociale ziektekostenverzekeringen, maar hen de toegang tot verzekeringsaanspraken te ontzeggen. ${ }^{52}$ In zijn advies wees de Raad deze optie van de hand omdat hij dit in strijd achtte met de verzekeringsgedachte. Iemand die verzekerd is en premie betaalt dient ook toegang te hebben tot de verzekeringsaanspraken, aldus de Raad. Het kabinet diende volgens de Raad te kiezen uit de volgende twee opties: ofwel mensen zonder rechtmatig verblijf de toegang tot de verzekering ontzeggen, ofwel mensen zonder rechtmatig verblijf de mogelijkheid blijven bieden verzekerd te zijn waardoor zij principieel toegang tot de verzekeringsaanspraken zouden behouden. ${ }^{53}$

Naar aanleiding van dit advies koos het kabinet ervoor om bepaalde categorieën rechtmatig verblijvende vreemdelingen toegang tot de verzekeringsaanspraken te laten behouden. Voor niet-rechtmatig in Nederland verblijvende vreemdelingen koos het kabinet voor uitsluiting van de (toenmalige) $\mathrm{Zfw}$ en AWBZ. ${ }^{54}$ Hiermee werd de weg van de koppelingsgedachte ingeslagen. ${ }^{55}$ De Raad liet zich overigens kritisch uit over de gedachte om de sociale (ziektekosten)verzekeringen in te zetten teneinde illegaal verblijf van vreemdelingen in Nederland tegen te gaan. Deze verzekeringen zijn daar volgens de Raad niet voor bedoeld en mogen daar ook niet voor gebruikt worden. De toegang tot noodzakelijke medische zorg voor illegale vreemdelingen diende volgens de Raad gewaarborgd te zijn. ${ }^{56}$ Volgens het kabinet zou

\footnotetext{
${ }^{49}$ NRV 1995, p. 24.

${ }^{50}$ De Groot 1997, TvGR 1997/1, p. 2-9, onder verwijzing naar Algemeen Dagblad, 7 november 1996.

51 Ziekenfondsraad 1992. De Ziekenfondsraad was de voorloper van het CVZ respectievelijk ZiNL. De Ziekenfondsraad was van 1949 tot 1999 adviesorgaan en droeg in die hoedanigheid bij aan de totstandkoming en ontwikkeling van de wettelijke zorgverzekeringen.

52 In die periode kwam het regelmatig voor dat illegaal verblijvende vreemdelingen uit hoofde van een dienstverband verzekerd waren.

${ }^{53}$ Ziekenfondsraad 1992 uitgave 553. Het advies is online niet beschikbaar. Voor de inhoud ervan is de MvT van de Koppelingswet als bron geraadpleegd, p. 48-49.

${ }^{54}$ Kamerstukken II 1994/95, 24 233, nr. 3, p. 48.

${ }^{55}$ Kamerstukken II 1994/95, 24 233, nr. 3, p. 48.

${ }^{56}$ Kamerstukken II 1994/95, 24 233, nr. 3, p. 48.
} 
het koppelingsbeginsel die toegang 'geheel onverlet' laten. De ziektekosten dienen in beginsel echter niet ten laste van de sociale ziektekostenverzekeringen te komen. ${ }^{57}$ De kosten van preventieve gezondheidszorg werden al door de overheid gefinancierd. Daarin bracht het wetsvoorstel volgens het kabinet geen wijziging. ${ }^{58}$

\subsubsection{Advies Ziekenfondsraad 1995}

Toen het kabinet ervoor koos om onrechtmatige vreemdelingen niet hun recht op aanspraken uit de verzekering te ontzeggen, maar hen van de verzekering uit te sluiten, bracht de Ziekenfondsraad in 1995 op verzoek van de toenmalige Minister van VWS opnieuw een advies uit. ${ }^{59}$ Dit advies ging in op de uitvoeringstechnische aspecten van de ziektekostenverzekeringen verbonden aan het wetsvoorstel van de Koppelingswet. Evenals in het advies van 1992, stelde de Raad in dit advies voorop dat voor onverzekerde illegale vreemdelingen de toegang tot de noodzakelijke zorg gewaarborgd dient te zijn. Deze toegang achtte de Raad noodzakelijk, enerzijds vanwege de maatschappelijke gedachte dat onrechtmatige vreemdelingen niet verstoken mogen blijven van noodzakelijke medische zorg, en anderzijds vanuit de gedachte dat onbehandelde ziekten aanzienlijke gezondheidsrisico's voor anderen kunnen opleveren. ${ }^{60} \mathrm{De}$ Raad was van mening dat het kabinet een regeling zou moeten treffen voor de kosten die gemoeid zijn met aan onverzekerde vreemdelingen verleende medische hulp. De kosten van deze hulpverlening zouden ten laste van de Rijksbegroting moeten komen. Met een dergelijke regeling zou worden voorkomen dat hulpverleners en hulpverlenende instellingen medische hulp zouden onthouden aan onverzekerden, aldus de Raad. ${ }^{61}$

\subsubsection{Uitzondering op het koppelingsbeginsel: (acute) medisch noodzakelijke zorg}

\subsubsection{Wettelijke positivering}

Het oorspronkelijke wetsvoorstel Koppelingswet formuleerde een tweetal uitzonderingen op het koppelingsbeginsel, te weten het recht op onderwijs en het recht op rechtsbijstand. ${ }^{62} \mathrm{De}$ regering vond wettelijke positivering van een derde uitzondering - in de MvT van de Koppelingswet geformuleerd als de situatie waarin de verlening van medische zorg niet kan worden uitgesteld of onthouden zonder het leven of de gezondheidstoestand van de betrokkene dan wel de Nederlandse volksgezondheid ernstig in gevaar te brengen - om de volgende redenen niet nodig.

In de eerste plaats noopte de redactie van het koppelingsbeginsel volgens de regering daartoe niet. De MvT noemt als voorbeeld het geval waarin een vreemdeling zonder rechtmatig verblijf zich laat behandelen in een openbaar ziekenhuis. In zo'n geval is volgens de regering louter sprake van feitelijk handelen en niet van een voorziening die bij overheidsbeschikking wordt geboden. Bovendien bestaat voor de vreemdeling volgens de regering geen subjectief

\footnotetext{
${ }^{57}$ Kamerstukken II 1994/95, 24 233, nr. 3, p. 49.

${ }^{58}$ Kamerstukken II 1994/95, 24 233, nr. 3, p. 23.

${ }^{59}$ Ziekenfondsraad 1995.

${ }^{60}$ Ziekenfondsraad 1995, p. 11.

${ }^{61}$ Ziekenfondsraad 1995, p. 11-12.

${ }^{62}$ Kamerstukken II 1994/95, 24 233, nr. 2, art. 8b lid 2 en 3.
} 
recht op dergelijk feitelijk handelen. Het koppelingsbeginsel laat de toegang van vreemdelingen ongeacht hun verblijfspositie tot de openbare gezondheidszorg geheel onverlet. Zoals het koppelingsbeginsel was geformuleerd, was het volgens de MvT niet noodzakelijk de vreemdelingen - die dringend behoefte hebben aan medische hulp, ook al wordt die hulp van overheidswege verstrekt - bij wet van het koppelingsbeginsel uit te zonderen. ${ }^{63}$

Ten tweede stelde de regering dat een uitzondering voor medische zorg niet nodig was omdat deze al voldoende verankering had in het Nederlandse recht. Daarbij doelde de regering op de zorgplichten van zowel de overheid als private personen (waaronder private instellingen) die met zich meebrengen dat mensen als dat nodig is een voorziening wordt geboden die aan acuut gevaar een einde maakt. De regering doelde daarbij kennelijk op de hulpverleningsplicht in enge zin (de strafrechtelijk gesanctioneerde verplichting in noodsituaties hulp te verlenen, artikelen 255 en $450 \mathrm{Sr}$ ), die op iedereen - ongeacht verblijfstitel - van toepassing is, overigens zonder dat zij hierop subjectief aanspraak kunnen maken. ${ }^{64}$

Tegenover deze zorgplicht staat volgens de MvT geen gehoudenheid van de overheid om hulpverleners daarvoor financieel te compenseren. ${ }^{65}$ Dit standpunt stond overigens los van de bereidheid van de regering om te voorzien in een 'zekere dekking' van het voorzienbare risico dat de overheidsinstellingen en particulieren in de toekomst zouden lopen, welke voorziening door de overheid als onverplicht werd beschouwd. ${ }^{66}$

Naar aanleiding van de kritische opmerkingen in het verslag en de reacties uit de kring van de gezondheidszorg, werd in de Nota van Wijziging van de Koppelingswet de uitzondering alsnog opgenomen met de formulering 'de gezondheidszorg in acute noodsituaties, de voorkoming van inbreuken op de volksgezondheid' ${ }^{67}$ Later werd het begrip de gezondheidszorg in acute noodsituaties' vervangen door de woorden 'de verlening van medisch noodzakelijke zorg', de huidige formulering in artikel 10 lid 2 Vw. ${ }^{68}$

\subsubsection{Financiering medisch noodzakelijke zorg}

Wat houdt de wettelijk gepositiveerde uitzondering op het koppelingsbeginsel in concreto in? De regering heeft tijdens de parlementaire behandeling van de Koppelingswet herhaaldelijk benadrukt (zoals hierboven al vermeld) dat deze wet geen betrekking heeft op de toegang tot de gezondheidszorg van onrechtmatige vreemdelingen. ${ }^{69}$ Deze toegang blijft volgens de regering geheel onverlet en ten principale de facto mogelijk. Met de Koppelingswet streefde de overheid ernaar om de medische zorg aan illegalen niet ten laste te laten komen van de collectieve middelen. Een uitzondering hierop wilde de overheid maken voor situaties waarin sprake is van medisch noodzakelijke (oorspronkelijk acute) zorg aan vreemdelingen zonder rechtmatig verblijf, waarvan de kosten niet kunnen worden verhaald op de betreffende

\footnotetext{
${ }^{63}$ Kamerstukken II 1994/95, 24 233, nr. 3, p. 14-15.

${ }^{64}$ Immers, alleen de overheid kan deze strafrechtelijk gesanctioneerde hulpverleningsplicht afdwingen, aldus de MvT, Kamerstukken II 1994/95, 24 233, nr. 3, p. 18.

${ }^{65}$ Kamerstukken II 1994/95, 24 233, nr. 3, p. 17.

${ }^{66}$ Kamerstukken II 1994/95, 24 233, nr. 3, p. 17-18.

${ }^{67}$ Kamerstukken II 1995/96, 24233 nr. 7, p. 9.

${ }^{68}$ Kamerstukken II 1996/97, 24 233, nr. 18 (waarin de wijziging werd geformuleerd als 'noodzakelijke medische zorg') en Kamerstukken II 1996/97, 24 233, nr. 43 (gewijzigd amendement ter vervanging van nr. 18, waarin de wijziging werd geformuleerd als 'medisch noodzakelijke zorg'). Zie par. 3.3.4.3 van dit proefschrift.

${ }^{69}$ Onder meer Kamerstukken II 1994/95, 24 233, nr. 3, p. 15, Kamerstukken II 1995/96, 24233 nr. 6, p. 57.
} 
vreemdeling of op derden. De regering was bereid om te zorgen voor 'een zekere overheidsdekking' in dergelijke gevallen, omdat het risico dat rekeningen voor verleende medisch noodzakelijke zorg aan illegalen onbetaald zouden blijven, niet alleen door de zorgverleners ('een van te voren te definiëren categorie') gedragen diende te worden. ${ }^{70}$ Een dergelijke voorziening werd volgens de regering geheel onverplicht in het leven geroepen. Zij zou haar kunnen nalaten, aldus de MvT. ${ }^{71}$ De Minister van VWS wilde de gelden hiervoor onderbrengen in een afzonderlijk fonds.

Uit het fonds zou een gehele of gedeeltelijke tegemoetkoming worden verleend aan een zorgverlener voor onbetaalde rekeningen indien in het individuele geval was voldaan aan de volgende voorwaarden:

1. het moet gaan om aan een illegaal verleende, en in het desbetreffende geval adequate en onvermijdelijke medische zorg;

2. verleend in een acute medische noodsituatie, c.q. in een geval waarin de Nederlandse volksgezondheid is gemoeid;

3. waarbij de zorgverlener ten genoege van de fondsbeheerder aannemelijk moet maken dat de kosten niet op de illegaal zelf of op een derde verhaalbaar zijn en

4. waarbij naar het oordeel van de fondsbeheerder sprake is van kennelijke hardheid indien in het desbetreffende geval de rekening niet alsnog geheel of gedeeltelijk wordt betaald. ${ }^{72}$

Volgens toenmalig minister van VWS Borst-Eilers legde de regering de Kamer met deze uitgangspunten geen volledige, optimale regeling voor maar deed de regering ook een beroep op ieders medemenselijkheid. Dit zou niet irreëel zijn, want die situatie bestond al. ${ }^{73}$ Volgens de minister riep de wetgever slechts een vangnetconstructie voor de financiële gevolgen in het leven, waarbij niet alles vooraf helemaal sluitend tot in de details geregeld was. ${ }^{74}$ Oorspronkelijk was het de bedoeling van de wetgever dat zorgverleners een beroep op het Koppelingsfonds konden doen na het adequaat verlenen van medische zorg in acute noodsituaties.

Diverse fracties plaatsten kanttekeningen bij de vraag of deze voorwaarden wel voldoende duidelijk waren voor praktische toepassing. Zij vroegen of het tweede en derde vereiste ook werkelijk bewijsbaar zouden zijn, welke criteria daarvoor zouden worden gehanteerd en hoe daaraan zou worden getoetst. ${ }^{75}$ Naar aanleiding van deze kritiek alsmede commentaar uit het veld (bezorgdheid over de wijze waarop de gezondheidszorg voor illegalen kan worden bemoeilijkt door invoering van het wetsvoorstel en met name door de toepassing van de genoemde voorwaarden) gaf de wetgever een nadere uitwerking aan bovengenoemde voorwaarden. ${ }^{76} \mathrm{Er}$ werd een onderscheid gemaakt tussen de zorginhoudelijke en de

\footnotetext{
${ }^{70}$ Kamerstukken II 1994/95, 24 233, nr. 3, p. 19.

${ }^{71}$ Kamerstukken II 1994/95, 24 233, nr. 3, p. 18.

${ }^{72}$ Kamerstukken II 1994/95, 24 233, nr. 3, p. 23.

${ }^{73}$ Handelingen II 16 oktober 1996, p. 852.

${ }^{74}$ Handelingen II 16 oktober 1996, p. 853.

${ }^{75}$ Kamerstukken II 1995/96, 24 233, nr. 4, p. 26.

${ }^{76}$ Kamerstukken II 1995/96, 24 233, nr. 6, p. 57-59.
} 
procedureel-technische voorwaarden waaronder tot uitkering uit het bedoelde fonds kon worden overgegaan. De zorginhoudelijke voorwaarden luidden:

1. het moet gaan om aan een illegaal verleende en in het desbetreffende geval adequate en onvermijdelijke medische zorg;

2. verleend in een acute medische noodsituatie, c.q. in een geval waarin de Nederlandse volksgezondheid is gemoeid.

Deze twee zorginhoudelijke criteria werden door de wetgever als volgt geïnterpreteerd. Situaties waarin aan illegalen verleende zorg in aanmerking voor vergoeding zou komen uit het fonds ${ }^{77}$ :

1. Zorg verleend in of ter voorkoming van situaties van levensbedreiging, dan wel in of ter voorkoming van situaties van blijvend verlies van essentiële functies.

2. Zorg verleend in situaties waarin zich een gevaar voor derden voordoet. Dit geldt bijvoorbeeld voor bepaalde infectieziekten (in het bijzonder tbc) en bij psychische stoornissen die gepaard gaan met agressief gedrag. Ook zwangerschapszorg valt onder dit criterium. Daarnaast hebben kinderen van illegalen tevens toegang tot de preventieve jeugdgezondheidszorg alsmede tot een vaccinatieprogramma overeenkomstig het rijksvaccinatieprogramma.

De procedureel-technische (uitvoering)voorwaarden luidden als volgt:

3. waarbij de zorgverlener ten genoege van de fondsbeheerder aannemelijk moet maken dat de kosten niet op de illegaal zelf of op een derde verhaalbaar zijn;

4. waarbij naar het oordeel van de fondsbeheerder sprake is van kennelijke hardheid indien in het desbetreffende geval de rekening niet alsnog geheel of gedeeltelijk wordt betaald.

De wetgever was van mening dat met bovenstaande interpretatie van de criteria gewaarborgd was dat noodzakelijke zorg ook voor illegalen toegankelijk zou blijven.

\subsubsection{Achtergrond formulering 'medisch noodzakelijke zorg'}

Het antwoord op de vraag welke zorg aan onrechtmatig verblijvende vreemdelingen gegeven mag of dient te worden, is in de wetsgeschiedenis verschillend uitgelegd. In de MvT van de Koppelingswet werd gesproken van adequate en onvermijdelijke medische zorg in 'acute medische noodsituaties' c.q. waar de volksgezondheid in het geding is. Aan deze formulering lag het advies van de commissie Zeevalking ten grondslag. Het criterium 'acute nood' gaf echter aanleiding tot veel verwarring en onduidelijkheid. Volgens minister Borst-Eilers ging het om situaties waarin acuut medische hulp nodig is vanwege levensgevaar of een acute, gezondheidsbedreigende toestand of gevaar voor anderen. Het vaststellen van wat onder 'acute nood' valt, werd aan de arts overgelaten. De overheid diende zich daar volgens de minister niet mee te bemoeien. ${ }^{78}$

Uiteindelijk werd de definitie naar aanleiding van bezwaren gewijzigd in 'medisch

\footnotetext{
${ }^{77}$ De regering volgde hierbij voor een belangrijk deel de suggesties van V\&W.

${ }^{78}$ Kamerstukken II 1994/95, 24 126, nr. 4, p. 33.
} 
noodzakelijke zorg'. Dit sloot aan bij wat in de meeste voorwaarden van particuliere ziektekostenverzekeringen was opgenomen. Hieronder werd verstaan verpleging, onderzoek of behandeling die volgens algemeen erkende, medisch wetenschappelijke overwegíngen noodzakelijk is. Uitgangspunt bleef dat het de behandelend medicus is die bepaalt of het verlenen van zorg medisch noodzakelijk is. ${ }^{79}$ Aangezien de term medisch noodzakelijke zorg cruciaal is voor de financiering van medische zorg verleend aan ongedocumenteerden, is hoofdstuk vijf geheel aan dit thema gewijd.

\subsection{Zorgen over (mogelijke) gevolgen van de Koppelingswet voor de gezondheidszorg}

De Nationale Raad voor de Volksgezondheid (NRV) bracht in 1995 een kritisch advies uit over de gevolgen van de Koppelingswet voor de gezondheidszorg. ${ }^{80}$ De conclusie luidde dat de Koppelingswet de toegang tot de gezondheidszorg flink zou bemoeilijken. De NRV betwijfelde of het beroep op de gezondheidszorg door illegaal verblijvende vreemdelingen wel zal afnemen door de nieuwe maatregelen. Niet ondenkbaar was dat de algemene volksgezondheid zou worden bedreigd door toename van onbehandelde ziekten zoals tbc. Ook betwijfelde de NRV of de Koppelingswet een effectieve bijdrage zou leveren aan het terugdringen van illegaal verblijf. Afgezien van welbewust medisch toerisme is het volgens de NRV twijfelachtig of het gebruik van hoogwaardige gezondheidszorg een motief is voor migranten om asiel aan te vragen of illegaal Nederland binnen te komen. ${ }^{81}$

Forse kritiek op de gevolgen van het wetsvoorstel Koppelingswet voor de gezondheidszorg werd geuit in de gezondheidsrechtelijke literatuur. Gevers wees erop dat de overheid zich aan haar eigen verantwoordelijkheid onttrok door de financiering als 'geheel onverplicht' te bestempelen. Volgens hem zou de Koppelingswet het recht op zorg van illegalen uithollen. ${ }^{82}$ Ook vroeg hij zich af of het voorgestelde régime zou voldoen aan de criteria van noodzaak en proportionaliteit tussen doel (terugdringing illegaal verblijf) en middel (beperkte toegang tot zorg). Toebes zag als minimum-verplichting van de overheid de zorg ingevolge de Zwf en AWBZ zag. Het wetsvoorstel stond volgens haar op gespannen voet met zowel de Grondwet als internationale mensenrechtenbepalingen. Voorts wees zij op het kunstmatige karakter van het onderscheid tussen de financiering van zorg (waar de Koppelingswet volgens de wetgever uitsluitend op zag) en de toegang ervan. ${ }^{83}$ Hendriks wees erop dat beroepsbeoefenaars als gevolg van de invoering van de Koppelingswet voor juridische, ethische en financiële dilemma's zouden konden staan. De Koppelingswet zou tot gevolg kunnen hebben dat hulpverleners en hulpverlenende instellingen in mindere mate bereid zouden zijn om behandelingsovereenkomsten met illegale vreemdelingen af te sluiten, of alleen na het sluiten van betalingsafspraken met deze patiënten. Ook verwachtte hij dat het opwerpen van financiële barrières met bijbehorende administratieve rompslomp ertoe zou leiden dat illegale vreemdelingen minimaal gebruik zouden kunnen maken van de diensten en adviezen van professionele hulpverleners, met alle gezondheidsgevolgen van dien. Door angst te worden

\footnotetext{
${ }^{79}$ Brief aan de Voorzitter van de Tweede Kamer der Staten-Generaal betreffende het Koppelingsfonds d.d. 17 maart 1999 (GVM/MO/991069).

${ }^{80}$ NRV 1995. De NRV ging in 2015 op in de Raad voor Volksgezondheid en Samenleving.

${ }^{81}$ NRV 1995, p. 6.

${ }^{82}$ Gevers, TvGR $2010 / 5$, p. 363-371.

${ }^{83}$ Toebes 1996, Migrantenrecht 1996/3, p. 197-199.
} 
aangemeld bij de vreemdelingenpolitie zouden illegalen te weinig een beroep kunnen doen op de noodzakelijke medische zorg. De Koppelingswet zou volgens hem kunnen leiden tot defensieve geneeskunde, waardoor de feitelijke toegang tot zorg voor illegale vreemdelingen zou worden afgesloten. De wet zou vooral nadelige (gezondheidszorg)effecten hebben voor illegale vrouwen en kinderen. ${ }^{84}$ De Groot tenslotte vroeg zich af in hoeverre onverzekerde illegalen in de toekomst aanspraak zouden maken op zorg, onder meer omdat hij betwijfelde of het afsluiten van een particuliere ziektekostenverzekering een reële optie zou zijn voor illegalen. Volgens hem kon de Nederlandse overheid niet zomaar afstappen van internationale verdragen waaruit bepaalde zorgplichten voortvloeien, zeker niet waar het gaat om de zorg voor moeder en kind. ${ }^{85}$

De Koninklijke Nederlandsche Maatschappij tot bevordering der Geneeskunst (KNMG) achtte de Koppelingswet inhumaan en een gevaar voor de volksgezondheid. Gewezen werd op het feit dat de hulpverlener in een onmogelijke positie zou komen te verkeren bij een beroep op het fonds. Dit zou op gespannen voet staan met de zwijgplicht van de arts ex artikel $272 \mathrm{Sr}^{86}$ Ook de Inspectie voor de Gezondheidszorg (IGZ, thans Inspectie voor Gezondheid en Jeugd, IGJ) maakte zich ernstige zorgen en drong erop aan de gevolgen van de invoering van de wet te monitoren. ${ }^{87}$

\subsection{Conclusie}

De Koppelingswet heeft als doel het terugdringen van onrechtmatig verblijf en het voorkomen van het verwerven van een schijn van legaliteit. Daartoe zijn onrechtmatig verblijvende vreemdelingen uitgesloten van sociale voorzieningen, waaronder de (sociale) ziektekostenverzekeringen. Aanvankelijk vond de regering het niet nodig om een uitzondering op het koppelingsbeginsel te maken voor medisch noodzakelijke zorg. Kritiek hierop leidde tot de wettelijk gepositiveerde uitzondering medisch noodzakelijke zorg. Deze uitzondering op het koppelingsbeginsel heeft de meeste aandacht in de parlementaire geschiedenis gehad. Vanuit de literatuur is gewezen op mogelijke strijd van de Koppelingswet met internationale verplichtingen van de overheid, het discriminatieverbod en het recht op gezondheidszorg (de minimale kern). Specifiek vanuit de gezondheidsrechtelijke literatuur werd gevreesd dat de Koppelingswet het recht op gezondheidszorg van de onrechtmatig verblijvende vreemdeling zou aantasten. Ook werd verenigbaarheid met de beginselen van noodzaak en proportionaliteit betwijfeld. Anno 2020 is de Koppelingswet nog steeds van kracht. Het koppelingsbeginsel is echter geen rustig bezit gebleken. In hoofdstuk acht wordt dit verder uitgewerkt.

\footnotetext{
${ }^{84}$ Hendriks, Migrantenrecht 1996/3, p. 51-56.

${ }^{85}$ De Groot, TvGR 1997/1, p. 2-9.

${ }^{86}$ KNMG 1995, p. 135.

${ }^{87}$ Voogt e.a. 1999, p. 22.
} 


\title{
Hoofdstuk 4 Financiering van medische zorg aan vreemdelingen zonder rechtmatig verblijf
}

\author{
Na het opheffen van de Stichting Koppeling, blikt \\ het bestuur van de stichting terug op meer dan tien \\ jaar functioneren en laveren tussen \\ vreemdelingenbeleid en volksgezondheidsbeleid. \\ Eén van de oprichters, E. van der Veen, vat de tien \\ jaar als volgt samen: "We moesten proberen het \\ onregelbare te regelen. En we brachten het onder \\ bij een stichting zodat het wegbleef bij de minister \\ en deze er ook geen vragen over zou krijgen." Kern \\ van de terugblik is dat de zorgverlening aan \\ vreemdelingen zonder papieren gedurende het \\ régime van de Regeling Stichting Koppeling \\ doorgaans goed is gegaan.
}

Bron: Evenblij 2011.

\subsection{Inleiding}

In het vorige hoofdstuk is besproken wat de uitgangspunten van de Koppelingswet ten aanzien van de gezondheidszorg zijn. Dit hoofdstuk zet uiteen op welke wijze de overheid het recht op medisch noodzakelijke zorg van onrechtmatig verblijvende vreemdelingen in de Nederlandse wet- en regelgeving heeft vormgegeven en financiert. Het beoogt dan ook een antwoord te geven op deelvraag 2: hoe zijn de aanspraken op gezondheidszorg van onrechtmatig verblijvende vreemdelingen in het Nederlandse systeem concreet vormgegeven?

Voordat het hoofdstuk ingaat op de vormgeving en financiering van medisch noodzakelijke zorg aan ongedocumenteerden vindt allereerst een analyse plaats van de wijze waarop het koppelingsbeginsel in de zorgwetten is geïncorporeerd. Hiermee ontstaat inzicht in de veelheid aan regelingen voor medische zorg voor de verschillende categorieën vreemdelingen. Het hoofdstuk vervolgt met de regeling die geldt voor financiering van medisch noodzakelijke zorg aan de onrechtmatig verblijvende vreemdeling, die is neergelegd in artikel 122a Zvw (hierna: de bijdrageregeling). Deze regeling verving het aanvankelijke illegalenfonds: het Koppelingsfonds, beheerd door de Stichting Koppeling. Achtergrond van de instelling en werkwijze van de Stichting Koppeling wordt gegeven, evenals de aanleiding om tot de nieuwe regeling over te gaan. Dan volgt een uitleg over de bijdrageregeling en de aard van de aanspraak die de onrechtmatig verblijvende vreemdeling op grond van deze regeling heeft. 
Naast de bijdrageregeling is de Regeling Medische zorg Asielzoekers (RMA) ${ }^{1}$ relevant, omdat deze van toepassing is op uitgeprocedeerde asielzoekerskinderen die in gezinslocaties verblijven. De RMA is onderdeel van de Regeling verstrekkingen asielzoekers en andere categorieën vreemdelingen 2005 (Rva 2005). ${ }^{2}$

Daarna wordt volledigheidshalve kort ingegaan op de regelingen die gelden voor de (financiering van) medische zorg voor uitgeprocedeerde vreemdelingen in COAopvanglocaties en vreemdelingen in detentiecentra.

\subsection{Het koppelingsbeginsel in het huidige zorgverzekeringsstelsel}

\subsubsection{Inleiding}

De Vw kent een differentiatie in de aanspraken van vreemdelingen die Nederland verblijven. De feitelijke toekenning van aanspraken op sociale voorzieningen is in de materiewetten geregeld. Het koppelingsbeginsel vinden we terug in de Zvw, de Wlz en de Wmo. In deze paragraaf wordt geanalyseerd hoe het koppelingsbeginsel in deze wetten is geïncorporeerd en welke categorie vreemdelingen volgens de genoemde wetten onder de kring der verzekerden valt. Deze wetten maken onderdeel uit van het Nederlandse zorgstelsel. Alhoewel dit proefschrift ziet op gezondheidszorg en niet op maatschappelijke opvang, is de Wmo toch wel van belang in verband met jurisprudentie over het koppelingsbeginsel (zie hoofdstuk acht).

\subsubsection{Zorgverzekeringsstelsel}

Op grond van artikel $22 \mathrm{Gw}$ treft de overheid maatregelen ter bevordering van de volksgezondheid. Onder bevordering valt volgens de wetsgeschiedenis ook bescherming. ${ }^{3}$ Het gaat hierbij niet alleen om bescherming tegen dreigende gevaren, maar ook om bevordering van de volksgezondheid zonder dat direct sprake is van dreigende gevaren. Bij dit laatste dacht de wetgever aan beleid ten aanzien van de verzekering van ziektekosten, de prenatale zorg, de zuigelingenzorg, schoolgeneeskundige diensten en het bevorderen van onderzoek op medisch terrein. ${ }^{4}$ De overheid dient de nodige stappen te ondernemen om het grondrecht te respecteren, te beschermen en te verwezenlijken. ${ }^{5}$ De overheid is verantwoordelijk voor toegankelijkheid van gezondheidszorg, inclusief de financiële toegankelijkheid. De overheid dient dan ook zorg te dragen voor collectieve financiering van noodzakelijke gezondheidszorgvoorzieningen.

Tot 2006 bestond in Nederland een duaal systeem van verzekeringen: beneden een bepaald inkomen was iemand verplicht verzekerd op grond van de Zfw. Overige ingezetenen dienden zich particulier te verzekeren. Daarnaast waren er publiekrechtelijke ziektekostenregelingen voor ambtenaren. De AWBZ gold voor alle ingezetenen en was bedoeld om dekking te bieden voor zware geneeskundige risico's zoals de gehandicaptenzorg. Met de komst van de

\footnotetext{
${ }^{1}$ Regeling Medische Zorg Asielzoekers (RMA), geldig per 1 januari 2019, rmasielzoekers.nl.

${ }^{2}$ Regeling verstrekkingen asielzoekers en andere categorieën vreemdelingen 2005. Voorheen was dit de Regeling verstrekkingen asielzoekers en andere categorieën vreemdelingen 1997 (Rva 1997), door de inwerkingtreding van de Vw gewijzigd, Wijziging Regeling verstrekkingen asielzoekers en andere categorieën vreemdelingen 1997 (Rva 1997).

${ }^{3}$ Kamerstukken II 1976/77, 13873, nr. 7, p. 23.

${ }^{4}$ Kamerstukken II 1976/77, 13873, nr. 7, p. 23

${ }^{5}$ Leenen e.a. 2017, p. 53.
} 
Zvw in 2006 kwam er een verplichte algemene verzekering tegen ziektekosten en werd de marktwerking in de zorg ingevoerd. Uitgangspunt van de Zvw is de wenselijkheid dat de gehele bevolking onder voor ieder gelijke sociale voorwaarden verzekerd is tegen de gevolgen van behoefte aan geneeskundige zorg. ${ }^{6}$ Voorzieningen die niet onder de verplichte verzekering vallen, kunnen via een aanvullende ziektekostenverzekering worden verzekerd. De Wlz bevat regels voor vergoeding van langdurige zorg.

De Zvw en de Wlz zijn van belang voor de medische zorg. Voor het sociale domein zijn de Wmo en de Jeugdwet relevant. De Wmo kent de gemeenten de verantwoordelijkheid toe voor deelname van alle burgers aan het maatschappelijk verkeer. Doel is het behoud of het vergroten van zelfredzaamheid, participatie, ondersteuning en maatschappelijke samenhang. ${ }^{7}$

Het Nederlandse zorgstelsel kent een privaatrechtelijk verzekeringsstelsel met publieke randvoorwaarden. De zorgverzekering is een privaatrechtelijke verzekering. In het wettelijk ziektekostenstelsel (Zvw en Wlz) komt de solidariteit tot uitdrukking. Het solidariteitsbeginsel is niet als zodanig wettelijk gepositiveerd, maar komt wel tot uiting in de uitgangspunten van risicosolidariteit en inkomenssolidariteit. ${ }^{8}$

\subsubsection{Hoofdlijnen Zvw, Wlz en Wmo}

De Zvw kent een verzekeringsplicht en een acceptatieplicht. ${ }^{9}$ Een ieder die volgens de Wlz van rechtswege verzekerd is valt onder de verzekeringsplicht van de Zvw. ${ }^{10}$ De Zvw voorziet in een basispakket aan curatieve zorg. Het Besluit zorgverzekering, de Regeling zorgverzekering en de modelovereenkomst van de zorgverzekeraar bevatten de te verzekeren prestaties. De verzekerde heeft recht op ofwel zorg in natura ofwel in restitutie. ${ }^{11} \mathrm{ZiNL}$ heeft een aantal ondersteunende en uitvoerende taken, waaronder het systematisch doorlichten van het basispakket. De NZa houdt op grond van de Wet marktordening gezondheidszorg (Wmg) toezicht op de zorgverzekeraars.

De Wlz is een publiekrechtelijke verzekering. Op grond van de Wlz is iedere ingezetene van Nederland verplicht en van rechtswege verzekerd voor langdurige zorg. Het is bedoeld voor mensen die voortdurend intensieve zorg nodig hebben in de nabije omgeving, zoals chronisch zieken, kwetsbare ouderen en mensen met een ernstige geestelijke of lichamelijke beperking of aandoening. ${ }^{12}$ Ingezetene is degene die in Nederland woont. ${ }^{13}$ De prestatievormen van de Wlz zijn zorg in natura of een persoonsgebonden budget (pgb). Zorgkantoren voeren een deel van de zorg uit. Het Centrum Indicatiestelling Zorg (CIZ) stelt het recht op zorg op aanvraag van

\footnotetext{
${ }^{6}$ Considerans Zvw.

${ }^{7}$ Art. 1.1.1 Wmo.

${ }^{8}$ Sijmons 2008, p. 65.

${ }^{9}$ Art. 2 (verzekeringsplicht) resp. art. 3 (acceptatieplicht) Zvw.

${ }^{10}$ Art. 2 lid $1 \mathrm{Zvw}$ jo art. 1.2.1 lid $1 \mathrm{a}$ Wlz.

${ }^{11}$ Art. $11 \mathrm{Zvw}$.

${ }^{12}$ Op grond van art. 3.1.1 Wlz zijn de verzekerde zorgvormen: verblijf in een zorginstelling, of waar mogelijk intensieve zorg thuis, begeleiding, verpleging en verzorging, medische zorg en (paramedische) behandeling in verband met de ziekte, beperking of stoornis, hulpmiddelen, dagbesteding, huishoudelijke hulp, vervoer naar de plaats waar de begeleiding, behandeling en verzorging plaatsvindt.

${ }^{13}$ Art. 1.2.1 Wlz.
} 
de Wlz-verzekerde in een indicatiebesluit vast. ${ }^{14}$ De voorbereiding van een indicatiebesluit omvat in ieder geval een onderzoek van de verzekerde in persoon. ${ }^{15}$ Voorafgaand aan het nemen van een indicatiebesluit dient het CIZ zich ervan te vergewissen dat degene voor wie het indicatiebesluit is aangevraagd, verzekerd is. ${ }^{16}$ Het CIZ mag een indicatie voor zorg weigeren als de aanvrager geen rechtmatig verblijf heeft. Uit de wettekst en de wetsgeschiedenis van de Wlz blijkt dat een systeem is geïntroduceerd waarbij het CIZ het recht op zorg alleen op aanvraag van een verzekerde vaststelt. Voor niet-verzekerden - dus ook onrechtmatig verblijvenden - geldt dat zij voor zorg direct dienen aan te kloppen bij een zorgaanbieder. ${ }^{17}$

\subsubsection{Kring der verzekerden}

De verzekeringsplichtig krachtens de Zvw is, zoals hierboven vermeld, gekoppeld aan de kring der verzekerden van de Wlz. Uitgangspunt is dat ingezetenen van Nederland verzekerd zijn. ${ }^{18}$ Het ingezetenschap wordt beoordeeld aan de hand van economische, sociale en juridische factoren. Op grond van het koppelingsbeginsel zijn vreemdelingen die onrechtmatig in Nederland verblijven uitgezonderd van de verzekering. ${ }^{19}$ De Wlz kent uitzonderingen op deze hoofdregel. Bepaalde categorieën kinderen die niet rechtmatig in Nederland verblijven zijn wel verzekerd. ${ }^{20}$ Voorts kan bij of krachtens algemene maatregel van bestuur in afwijking van het tweede lid, uitbreiding worden gegeven aan de kring der verzekerden en voor een tweetal categorieën vreemdelingen. ${ }^{21}$ Dit is uitgewerkt in het Besluit uitbreiding en beperking kring verzekerden volksverzekeringen 1999. Voor bepaalde categorieën vreemdelingen geeft het Besluit uitbreiding in de artikelen 9a-11. Asielzoekers vallen niet eerder onder de kring der verzekerden van de Wlz dan met ingang van de dag waarop positief op een verblijfsvergunning is beslist. ${ }^{22}$ Een vreemdeling die na rechtmatig verblijf te hebben gehouden in de zin van artikel 8 , onder a tot en met e en $1 \mathrm{Vw}$ voor de beëindiging van dit verblijf een aanvraag heeft ingediend

\footnotetext{
${ }^{14}$ Art. 3.2.3 lid $1 \mathrm{Wlz}$. Het CIZ stelt indicaties voor zorg uit de Wlz, behandeling op grond van de Wlz, ADLassistentie (hulp bij algemene dagelijkse levensverrichtingen in een ADL-woning) en besluit tot opname en verblijf op grond van de Wet zorg en dwang (Wzd).

${ }^{15}$ Art. 3.2.2 lid 1 Besluit langdurige zorg (Blz).

${ }^{16}$ Art. 3.1 lid 1 Regeling langdurige zorg (Rlz).

${ }^{17}$ CRvB 1 februari 2017, ECLI:NL:RVB:2017:492, USZ 2017/113, zie hierna par. 8.2.3.4.

${ }^{18}$ Art. 2.1.1 Wlz.

${ }^{19}$ Art. 2.1.1 lid $2 \mathrm{Wlz}$

${ }^{20}$ Art. 2.1.1 lid 3 sub a en b Wlz. Het betreft: a. kinderen in Nederland geboren uit een in Nederland wonende vreemdeling die rechtmatig verblijf geniet als bedoeld in art. 8, onder a tot en met e of 1, van de Vw, dan wel in het buitenland geboren uit in Nederland wonende ouders die rechtmatig verblijf genieten als bedoeld in art. 8, onder a tot en met e of l, van de Vw; b. kinderen die door in Nederland wonende personen met de Nederlandse nationaliteit dan wel met rechtmatig verblijf als bedoeld in art. 8, onder a tot en met e of 1, van de Vreemdelingenwet 2000, worden geadopteerd en voor wie met het oog op adoptie beginseltoestemming is verleend op grond van art. 2 van de Wet opneming buitenlandse kinderen ter adoptie. De verzekering gaat in vanaf het moment van adoptie naar het recht van het land waar het kind zijn gewone verblijf heeft of vanaf het moment van de gezagsoverdracht van het kind met het oog op adoptie aan een echtpaar of een persoon die zijn gewone verblijf in Nederland heeft en die de procedure van opneming ter adoptie van een kind ingevolge de Wet opneming buitenlandse kinderen ter adoptie heeft gevolgd.

${ }^{21}$ Art. 2.1.1 leden 4 en 5 Wlz. Het gaat om: a. vreemdelingen die rechtmatig in Nederland arbeid verrichten dan wel hebben verricht; $b$. vreemdelingen die, na in Nederland rechtmatig verblijf te hebben genoten als bedoeld in art. 8, onder a tot en met e en 1 , van de Vw, tijdig toelating in aansluiting op dat verblijf hebben aangevraagd, dan wel bezwaar hebben gemaakt of beroep hebben ingesteld tegen de intrekking van het besluit tot toelating, totdat op die aanvraag, dat bezwaar of dat beroep is beslist.

${ }^{22}$ Art. 91 Besluit uitbreiding en kring verzekerden volksverzekeringen 1999.
} 
om voortgezette toelating valt ook onder de volksverzekeringen. ${ }^{23}$ Deze aanspraak eindigt zodra onherroepelijk op de aanvraag is beslist of indien uitzetting van de vreemdeling is gelast, tenzij die uitzetting op grond van de $\mathrm{Vw}$ of op grond van een rechterlijke beslissing achterwege dient te blijven. ${ }^{24}$

Zodra de asielzoeker (perfect) rechtmatig in Nederland verblijft, geldt de wettelijke verzekeringsplicht. Bepalend voor het tijdstip van ontstaan van de verzekeringsplicht is de datum van het afgeven van de verblijfsvergunning. ${ }^{25}$ Vanaf dat moment dient binnen drie maanden een zorgverzekering te worden afgesloten. De verzekeringsplicht geldt niet voor de statushouder die nog op een locatie van het COA verblijft (niet is 'uitgestroomd' naar huisvesting in de gemeente). Hij valt nog steeds onder de Rva 2005 en daarmee onder de RMA. ${ }^{26}$ Rechtmatig verblijf is ook een voorwaarde voor rechten uit hoofde van de Wmo. ${ }^{27}$ Zonder geldige verblijfstitel komt een in Nederland verblijvende vreemdeling in beginsel niet in aanmerking voor een voorziening op maat. ${ }^{28} \mathrm{Bij} \mathrm{AMvB}$ kan hierop een uitzondering worden gemaakt. ${ }^{29}$ Deze is tot op heden nog niet tot stand gekomen.

Vreemdelingen die rechtmatig in Nederland verblijven maar uitgezonderd zijn van toegang tot de Wlz (en daarmee tot de $\mathrm{Zvw}$ ) zijn vreemdelingen die een aanvraag voor een verblijfsvergunning regulier hebben ingediend en vreemdelingen die bezwaar of beroep hebben ingesteld tegen een afwijzende beslissing op een aanvraag voor een verblijfsvergunning regulier. Tezamen met de onrechtmatig verblijvende vreemdelingen vormen zij de categorie onverzekerbare vreemdelingen. Zij dienen de kosten voor verleende medische zorg in beginsel zelf te betalen. ${ }^{30}$

Een vreemdeling, die nooit asielzoeker is geweest, kan tussen de wal en het schip vallen

\footnotetext{
${ }^{23}$ Art. 10 lid 1 sub a Besluit uitbreiding en kring verzekerden volksverzekeringen 1999. Volgens de MvT van de Koppelingswet (Kamerstukken II 1994/95, 24 233, nr. 3, p. 27) dient onder 'voortgezette toelating' het volgende worden verstaan: "Voortgezette toelating wil in dit verband zeggen dat de aanvragers dezelfde grond aanvoeren die reeds eerder de Minister van Justitie bewoog tot de instemming met het bestendig verblijf van de vreemdeling hier te lande. In deze betekenis is steeds in het voorliggend wetsvoorstel de term "voortgezette toelating» gebezigd." Het begrip 'voortgezette toelating' wordt niet meer in de Vw en het Vreemdelingenbesluit 2000 gebezigd. De rechter toetst aan het criterium zoals in de MvT uitgelegd, zie CRvB 29 december 2015, ECLI:NL:CRVB:2015:4903. In deze zaak ging het om het al dan niet verzekerd zijn van een vreemdeling op grond van de Wet werk en bijstand (WWB). De vreemdeling beriep zich op het Besluit gelijkstelling vreemdelingen WWB, IOAW en IOAZ (Besluit gelijkstelling), waarin de kring der verzekerden is uitgebreid op eenzelfde wijze als in het Besluit uitbreiding en beperking kring verzekerden volksverzekeringen 1999.

${ }^{24}$ Art. 10 lid 2 sub a en b Besluit uitbreiding en beperking kring verzekerden volksverzekeringen 1999.

${ }^{25}$ Art. 9a Besluit uitbreiding en beperking kring verzekerden volksverzekeringen 1999. Volgens dit artikel is een vreemdeling die rechtmatig in Nederland verblijft, in de zin van art. 8 onder c, van de Vreemdelingenwet 2000, ongeacht of hij als ingezetene kan worden beschouwd, niet eerder verzekerd op grond van de volksverzekeringen dan met ingang van de dag waarop positief op de verblijfsvergunningsaanvraag wordt beschikt. Zie ook Geschillencommissie Zorgverzekeringen 11 februari 2015, 2013.02787, GJ 2015/49, waarin de commissie ingaat op het begrip 'ingezetene'. Ingezetenschap is afhankelijk van de juridische binding, die pas tot stand komt wanneer is vastgesteld dat de vreemdeling rechtmatig verblijf houdt in Nederland, zie overwegingen 9.1-9.3. De Geschillencommissie had mijns inziens kunnen volstaan met het verwijzen naar art. 9a van voornoemd Besluit.

${ }^{26}$ CRvB 24 februari 2016, ECLI:NL:CRVB:2016:615, GJ 2016/57, AB 2016/146, m.nt. A.C. Hendriks.

${ }^{27}$ Art. 1.1.2 Wmo.

${ }^{28}$ Art. 1.2.2 lid $1 \mathrm{Wmo.}$

${ }^{29}$ Art. 1.2.2 lid $3 \mathrm{Wmo.}$

${ }^{30}$ Modeljaarverslaglegging CAK, Bestuurlijke verantwoording burgerregelingen 2019, Staatscourant 2020, 28911, p. 26.
} 
indien hij uitstel van vertrek heeft gekregen op grond van artikel $64 \mathrm{Vw} .{ }^{31}$ Had hij wel een asielaanvraag ingediend, dan viel hij onder de Rva 2005 (artikel 3 lid 3 onder f Rva 2005). Nu hij dat niet heeft gedaan, valt hij onder de uitzonderingscategorie van de Rva 2005 (artikel 3 lid 3 onder f Rva 2005) waardoor hij ook niet onder de RMA valt. Omdat hij rechtmatig verblijf heeft, valt hij evenmin onder artikel 122a Zvw. Voor aanspraken op verstrekkingen dient hij zich tot de Staatssecretaris te wenden. ${ }^{32}$

\subsubsection{Uitzondering op het koppelingsbeginsel in individuele gevallen}

Vreemdelingen die niet onder de kring der verzekerden van de Wlz (en daarmee de Zvw) vallen, kunnen desondanks met een beroep op internationale verdragen trachten het koppelingsbeginsel buiten toepassing te laten verklaren bij de rechter. Dit kunnen zij doen met een beroep op schending van (onder meer) artikel 8 EVRM. ${ }^{33}$ Ten aanzien van kinderen kan toepassing van het koppelingsbeginsel ook schending van artikel 24 lid 1 IVBPR opleveren. ${ }^{34}$

Toen de AWBZ nog van toepassing was, werd artikel 5 lid 2 van deze wet - waarin het koppelingsbeginsel was neergelegd - in individuele gevallen vanwege schending met artikel 8 EVRM in uitzonderlijke gevallen buiten toepassing verklaard. Dit was met name het geval bij kinderen en kwetsbare personen. ${ }^{35}$ Hoofstuk acht bespreekt deze jurisprudentie. ${ }^{36}$

\subsection{Financiering van medisch noodzakelijke zorg voor onrechtmatig verblijvende vreemdelingen}

\subsubsection{Inleiding}

Zoals vermeld in paragraaf 3.3.4.2, wilde de overheid mogelijke 'minder billijke' gevolgen van de Koppelingswet voor zorgverleners verzachten door middel van het instellen van een illegalenfonds. ${ }^{37}$ Deze overheidsdekking bestond in eerste instantie uit het Koppelingsfonds, beheerd door de Stichting Koppeling. In 2009 kwam de huidige financieringsregeling tot stand, waarvoor artikel 122a Zvw de basis vormt. Aanleiding voor deze nieuwe regeling vormden de versnipperde financieringsregelingen, enkele rechterlijke uitspraken en de invoering van het nieuwe zorgstelsel, zoals hieronder beschreven. Deze paragraaf geeft een historische terugblik op de Stichting Koppeling die meer dan 10 jaar heeft gefunctioneerd.

\footnotetext{
${ }^{31}$ Art. 64 bepaalt dat uitzetting achterwege blijft zolang het gelet op de gezondheidstoestand van de vreemdeling of die van een van zijn gezinsleden niet verantwoord is om te reizen. Zie hoofdstuk 7.

${ }^{32}$ ABRvS 20 maart 2019, ECLI:NL:RVS:2019:903, JV 2019/104, m.nt. C.H. Slingenberg. In eerste instantie had de rechtbank de uitzondering vervat in art. 3, derde lid, aanhef en onder f, van de Rva 2005 als kennelijk onredelijk bestempeld en onverbindend verklaard wegens strijd met art. 34, tweede lid, van het EU-Handvest van de Grondrechten. Dit is in hoger beroep teruggedraaid omdat de situatie niet onder het bereik van het Unierecht zou vallen, hetgeen Slingenberg in haar annotatie betwist.

${ }^{33}$ Zie paragraaf 5.6.1 van dit proefschrift.

34 VN-Mensenrechtencomité 26 maart 2019, 2498/2014, RSV 2019/262, m.nt. P.E. Minderhoud (Abdoellaevna/Nederland).

${ }^{35}$ CRvB 20 oktober 2010, ECLI:NL:CRVB:2010:B03581, JV 2011/90, m.nt. P.E. Minderhoud, CRvB 4 augustus 2011, nr. 10/5236 AWBZ, RSV 2011/341, m.nt. C.W.C.A. Bruggeman, CRvB 9 september 2011, ECLI:NL:CRVB:2011:BT1738, nr. 11/4654 AWBZ/VV, RSV 2011/336, r.o. 412.

${ }^{36}$ Te weten in par. 8.2.3.4.

${ }^{37}$ Kamerstukken II 1994/95, 24 233, nr. 3, p. 4.
} 


\subsubsection{Voorgeschiedenis: Stichting Koppeling}

\subsubsection{Financieringsregelingen}

De overheid wilde niet direct bij het fonds betrokken zijn en beheerde het fonds/de regeling daarom niet zelf. De Stichting Koppeling werd particulier opgericht en bestuurd door vertegenwoordigers van de publieke gezondheidszorg en uit de kring van zorgverzekeraars. De Stichting Koppeling had als doel om op basis van een subsidierelatie met de overheid knelpunten in de regionale gezondheidszorg op te lossen, die ontstonden door de hulpvraag van onverzekerde illegalen, financieel te ondersteunen. ${ }^{38}$ Met het geld dat vrijkwam bij het Ministerie van Sociale Zaken in verband met invoeren van de Koppelingswet - geschat op 11 miljoen gulden (circa vijf miljoen euro, VD) - werd het illegalenfonds in eerste instantie gefinancierd. ${ }^{39}$

Het Koppelingsfonds regelde de financiering van eerstelijns zorg en AWBZ-zorg die niet door de patiënt zonder rechtmatig verblijf betaald kon worden. In eerste instantie (tot 2004) konden AWBZ-gefinancierde instellingen, zoals verpleeg- en verzorgingshuizen en GGZinstellingen, aanspraak maken op de Stichting Koppeling, indien zij een inkomensschade hadden groter dan één promille van het budget. Een beroep op de Stichting Koppeling verliep via regionale samenwerkingsverbanden. De Stichting Koppeling ontving een jaarlijkse subsidie van het Ministerie van VWS. Tweedelijns zorgverleners zoals ziekenhuizen, revalidatiecentra en ambulancediensten konden een beroep doen op de beleidsregel Afschrijvingskosten dubieuze debiteuren van (voorheen) de Wet Tarieven Gezondheidszorg (WTG).

Het Koppelingsfonds stelde voorwaarden voor financiering van medisch noodzakelijke zorg die een uitwerking waren van de zorginhoudelijke en procedureel-technische voorwaarden van de regering. ${ }^{40}$ Deze waren neergelegd in het Reglement financiële bijdragen Stichting Koppeling (RFB). ${ }^{41}$ Bepaalde zorgvormen waren van vergoeding uitgesloten, zoals transseksuele behandelingen, in-vitrofertilisatie (ivf), tandheelkundige hulp (met uitzondering van noodhulp). Door het stellen van deze randvoorwaarden werd beoogd te voorkomen dat het fonds een gemakkelijke uitweg biedt voor het vergoeden van onverzekerde zorg en dat er een aanzuigende werking op de aanwezigheid van illegalen zou uitgaan. ${ }^{42}$

Met het Koppelingsfonds gaf de overheid zoals gezegd op indirecte wijze vorm aan haar verantwoordelijkheid. Deze indirecte wijze van verantwoordelijkheid kan worden vergeleken met de financiële regeling die de overheid in 1995 trof ten behoeve van hemofiliepatiënten die

\footnotetext{
${ }^{38}$ Art. 3 van de statuten. Zie ook Van Es et al 1999, p. 17-18.

${ }^{39}$ Kamerstukken II 1994/95, 24 233, nr. 3, p. 4. De oprichting van het illegalenfonds diende budgettair neutraal te zijn.

${ }^{40}$ Zie paragraaf 3.3.4.2 van dit proefschrift.

${ }^{41}$ Er moest sprake zijn van 1. een onbetaalde rekening van personen die vanwege hun verblijfsstatus onverzekerd zijn; 2. De zorgverlener moest aannemelijk maken dat de kosten niet op de illegaal zelf of op een derde verhaalbaar zijn, 3. De kosten moesten een bovenmatige structurele belasting vormen voor de betrokken zorgverleners en/of zorginstellingen, 4 . Het moest gaan om medisch noodzakelijke zorg.

${ }^{42}$ Brief van de minister van VWS aan de Voorzitter van de TK, 21 maart 2000, Kamerstukken II 1999/00, 19 637, nr. 518.
} 
door bloedproducten waren besmet met hiv. ${ }^{43}$ De overheid trof de regeling uit 'bestuurlijkmorele gronden', maar erkende geen aansprakelijkheid. ${ }^{44}$

\subsubsection{Van 'geheel onverplicht' naar publieke taak}

De status van de Stichting Koppeling als onafhankelijk en op afstand van de overheid hield in rechte echter geen stand. Aanleiding voor de hieronder besproken rechtszaken vormde de afschaffing van de vergoeding van de AWBZ-zorg. Toenmalig minister van VWS Hoogervorst had hierop aangedrongen omdat het Koppelingsfonds volgens hem alleen bedoeld was voor financiële compensatie voor het verlenen van medisch noodzakelijke zorg die geen uitstel toelaat. ${ }^{45}$ De GGZ-instelling Stichting BAVO-RNO Groep had meer dan $€ 2,1$ miljoen uitgegeven aan de zorg voor illegale patiënten zonder daarvoor te zijn gecompenseerd. De BAVORNO Groep vorderde deze kosten van de Stichting Koppeling, die aanvoerde geen beslissing te kunnen nemen op het gemaakte bezwaar tegen afwijzing van de toekenning van de bijdrage omdat de Stichting geen bestuursorgaan zou zijn.

De rechtbank Rotterdam dacht daar anders over: de Stichting Koppeling oefende een publieke taak uit en was daarom te beschouwen als een bestuursorgaan. ${ }^{46}$ Volgens de rechtbank kon niet worden gezegd dat de overheid - zoals zij in de MvT bij de Koppelingswet stelt - het Koppelingsfonds onverplicht aan zich getrokken heeft. En ook al zou het wel onverplicht zijn, dan nog is er sprake van een overheidstaak nu de minister heeft erkend dat de betreffende taak het behartigen van een algemeen belang betreft. Door de opvatting van de wetgever dat de kosten van het geïntegreerde vreemdelingenbeleid niet alleen door de zorgsector gedragen behoren te worden, beriep de wetgever zich immers op het beginsel 'égalité devant les charges publiques' (oftewel nadeelcompensatie, VD) en bevestigde hij het publieke karakter van de taakuitvoering van de Stichting Koppeling. Voorts was de rechtbank van oordeel dat sprake was van een nauwe financiële relatie tussen de minister en de Stichting, nu de Stichting volledig door de overheid wordt gefinancierd en de voorwaarden voor vergoeding door de minister zijn geformuleerd. Gevolg van deze uitspraak - die in hoger beroep in stand bleef ${ }^{47}$ - was, dat beslissingen van de Stichting Koppeling vatbaar werden voor bezwaar en beroep.

Vervolgens oordeelde de voorzieningenrechter van de rechtbank Den Haag in 2006 dat de overheid onrechtmatig jegens Bavo-RNO Groep handelde door een adequate vergoeding achterwege te laten. ${ }^{48}$ In het midden bleef het antwoord op de vraag of de Staat op grond van

\footnotetext{
${ }^{43}$ Nationale ombudsman, Verzoekschrift van de Nederlandse Vereniging van Hemofiliepatiënten te Badhoevedorp met een klacht overeen gedraging van het Ministerie van Welzijn, Volksgezondheid en Cultuur, 1995. Rapportnr. 95/271. Den Haag: Bureau Nationale ombudsman, 1995. Aanleiding voor deze regeling was het rapport van Nationale ombudsman waarin werd geconcludeerd dat de het toenmalige Ministerie van VWS nalatig was geweest in het nemen van maatregelen die gericht waren op het voorkomen van hiv-bestemmingen bij ontvangers van bloedproducten in de periode halverwege jaren 80 van de vorige eeuw.

${ }^{44}$ Vaststelling van de begroting van de uitgaven en de inkomsten van het Ministerie van VWS (XVI) voor het jaar 1998; Brief van de Minister van VWS over financiële tegemoetkoming aan hemofiliepatiënten die zijn behandeld met hittebehandeld Factorate, 25600 XVI, nr. 63.

${ }^{45}$ Aanhangsel van de Handelingen, Kamerstukken II 2004/05, 357 (antwoord op Kamervragen van Arib).

${ }^{46}$ Rb. Rotterdam 16 december 2005, ECLI:NL:RBROT:2005:AV3486, GJ 2006/45, m.nt. V.L. Derckx.

${ }^{47}$ ABRvS 11 oktober 2006, ECLI:NL:RVS: 2006:AY9897, GJ 2006/148, m.nt. V.L. Derckx, JB 2006/321, m.nt. H. Peters, JIN 2007/45, RZA 2006, 196, AB 2007/81, m.nt. I. Sewandono.

${ }^{48}$ Rb. 's-Gravenhage (vzr.) 26 juli 2006, ECLI:NL:RBSGR: 2006:AY5099, GJ 2006/103, m.nt. V.L. Derckx, Bavo-RNO Groep/Staat.
} 
enig internationaal verdrag gehouden was tot vergoeding van de kosten aan de Bavo-RNO Groep, en dus aan een ander dan degene die behoefte heeft aan acute medische zorg. Volgens de voorzieningenrechter vond de toewijzing van de vordering zijn grondslag in het publieke belang van Bopz-zorg, namelijk de bescherming van de maatschappij en de betrokken illegaal zelf voor het gevaar dat voortvloeit uit zijn geestesstoornis. De rechter achtte het onevenredig als de instelling voor de kosten opdraait die voortvloeien uit de hulpverleningsplicht die zij heeft te bieden door overheidsmaatregelen op grond van de Wet bijzondere opnemingen in psychiatrische ziekenhuizen (Wet Bopz). ${ }^{49}$

Het gevolg van deze uitspraak was dat de minister concludeerde dat de zorg waarop illegalen aanspraak konden maken, nagenoeg alle zorgvormen betrof die waren opgenomen in het Nederlandse wettelijke sociale verzekeringspakket (Zvw en AWBZ), maar wel onder de voorwaarde dat de vraag of de zorg op dat moment in Nederland moest worden verleend positief werd beantwoord door de behandelend arts. De duur van het verblijf speelde dus een rol bij de overweging over de noodzaak van medische zorg. ${ }^{50}$

Al blijkt uit de hierboven besproken uitspraken dat de rechter de facilitering en financiering van het Koppelingsfonds door de overheid niet als vrijblijvend bestempelde, de vraag in hoeverre de overheid op grond van internationale verdragsverplichtingen gehouden was tot vergoeding van medisch niet-acute zorg, bleef open. In ieder geval vormden de uitspraken een belangrijke aanleiding tot herziening van de financieringsstructuur. De Stichting Koppeling werd opgeheven.

\subsubsection{Nieuwe stroomlijning financieringsstructuur}

Niet alleen de rechterlijke uitspraken, ook het nieuwe zorgverzekeringsstelsel noopte tot herziening van de financieringsstructuur. Na de inwerkingtreding van de Zvw met de daarbij behorende wijzigingen (verzekeringsplicht, wijzigingen in de ziekenhuisbekostiging) werd de vraag naar wat te doen met onverzekerden en oninbare vorderingen, nijpender. Van diverse zijden (Kamerleden, adviesorganen en beroepsorganisaties) werd bij de regering aangedrongen op een algemeen waarborgfonds voor onverzekerden, waaronder ook illegalen zouden vallen. ${ }^{51}$ De minister achtte een stroomlijning in de financieringsstructuur van verleende zorg noodzakelijk in die gevallen waarin de zorgkosten niet verhaald kunnen worden op de betrokken patiënt. Doel van de stroomlijning was om alle vormen van medisch noodzakelijke zorg die worden verleend aan in betalingsonmacht verkerende illegalen te financieren uit één door de overheid te financieren fonds.

In 2007 stemde de ministerraad in met een wetsvoorstel voor de regeling van de financiering van de zorg aan illegalen. De drie verschillende regelingen werden vervangen door

\footnotetext{
${ }^{49}$ Rb. 's-Gravenhage (vzr.) 26 juli 2006, ECLI:NL:RBSGR: 2006:AY5099, GJ 2006/103, m.nt. V.L. Derckx, Bavo-RNO Groep/Staat, r.o. 4.13.

${ }^{50}$ Brief van de Minister van VWS aan de Voorzitter van de Tweede Kamer, 16 oktober 2006, Z/VV-2723002.

${ }^{51}$ Kamerstukken II 2005/06, 29 689, nr. 66 (motie Vendrik en Kant), KNMG, GGZ-Nederland, NVZ, Vereniging van ziekenhuizen en de Federatie Opvang, 'Zorg verzekerd'. De invoering van de Zorgverzekeringswet en potentiële onverzekerden. Verslag van een VWS-onderzoek. Den Haag, 12 december 2005.
} 
één regeling zoals genoemd in artikel 122a Zvw. ${ }^{52}$ De doestelling van de wijziging was drieledig:

- Het stroomlijnen van de bestaande regelingen voor financiering van medisch noodzakelijke zorg aan illegalen en andere onverzekerbare vreemdelingen;

- Het creëren van een wettelijk kader dat zoveel mogelijk voorkómt dat verzekeringsplichtigen zich niet verzekeren;

- Het voorkómen dat aan zorgaanbieders de mogelijkheid wordt geboden om de kosten van zorg, verleend aan verzekeringsplichtigen, af te wentelen op de financieringsmogelijkheden ten behoeve van de doelgroep.

Met de nieuwe regeling werd de verantwoordelijkheid van de overheid voor verleende medisch noodzakelijke zorg aan onverzekerbare vreemdelingen wettelijk verankerd.

\subsection{De Regeling onverzekerbare vreemdelingen}

\subsubsection{Inleiding}

Artikel 122a Zvw regelt onder welke voorwaarden medisch noodzakelijke zorg verleend aan onverzekerbare vreemdelingen voor (gedeeltelijke) vergoeding in aanmerking komt. Na de beschrijving van deze voorwaarden gaat deze paragraaf in op de aard van de aanspraken die de vreemdeling aan deze regeling kan ontlenen.

\subsubsection{Uitgangpunten en voorwaarden voor vergoeding}

De financieringsregeling van artikel 122a Zvw regelt dat zorgverleners die inkomsten derven ten gevolge van het verlenen van zorg aan onverzekerbare vreemdelingen - onder wie vreemdelingen die geen rechtmatig verblijf hebben - onder bepaalde voorwaarden een bijdrage kunnen vragen bij het CAK. ${ }^{53}$ Uitgangspunt is dat iedere onverzekerbare vreemdeling waaronder de onrechtmatig verblijvende vreemdeling - zelf verantwoordelijk is voor de kosten van de aan hem verleende zorg.

De regeling onderscheidt twee soorten medisch noodzakelijke zorg: direct toegankelijke en niet-direct toegankelijke zorg. Onder direct toegankelijke zorg wordt verstaan de zorg die zonder recept, verwijzing of indicatie als bedoeld in de Wlz kan worden ingeroepen en die doorgaans ook direct moet worden verleend. Hieronder valt de meeste eerstelijnszorg (met uitzondering van farmaceutische hulp) en de acute ziekenhuiszorg. Niet-direct toegankelijke zorg is zorg die pas toegankelijk is na recept, verwijzing of indicatiestelling. Het gaat dan om zorg geleverd door apotheken, ziekenhuizen, GGZ-instellingen, verpleeghuizen en ambulancediensten. Voor beide soorten zorg geldt een verschillend vergoedingsregime. De oninbare kosten van direct toegankelijke zorg aan mensen zonder verblijfstitel worden aan alle zorgaanbieders voor $100 \%$ vergoed als het gaat om kosten die verband houden met zwangerschap en bevalling en voor $80 \%$ in de overige gevallen, de zogenoemde 80/20-

\footnotetext{
${ }^{52}$ Wet van 30 oktober 2008, houdende wijziging van de Zorgverzekeringswet in verband met de verstrekking van bijdragen aan zorgaanbieders die inkomsten derven ten gevolge van het verlenen van medisch noodzakelijke zorg aan bepaalde groepen vreemdelingen en van de Algemene Wet Bijzondere Ziektekosten met het oog op verzekering van bepaalde groepen minderjarige vreemdelingen, Staatsblad 2008, 527.

${ }^{53}$ Tot 1 januari 2017 ZiNL. Toen werden de burgerregelingen van het ZiNL naar het CAK overgeheveld.
} 
regeling. ${ }^{54}$ Gekozen is voor vergoeding van $80 \%$ omdat zowel de vreemdeling als de zorgverlener een eigen verantwoordelijkheid hebben (te weten: betalen c.q. verhalen van de kosten). Een volledige vergoeding van $100 \%$ zou volgens de minister in feite iedere prikkel voor de zorgaanbieder om de kosten te verhalen op de vreemdeling wegnemen. De zorgaanbieder heeft een inspanningsverplichting om te achterhalen of de onverzekerbare vreemdeling (een gedeelte van) de behandeling kan betalen.

Voor de indirect toegankelijke zorg geldt een contractstelsel. ${ }^{55}$ Alleen zorgaanbieders die het CAK voor dit doel tevoren heeft gecontracteerd, kunnen aanspraak maken op een tegemoetkoming in de kosten voor de zorg verleend aan vreemdelingen zonder verblijfstitel. Andere zorgaanbieders en instellingen kunnen dat niet. De contracten met ziekenhuizen en apotheken verlopen via een aanbestedingsprocedure. Het CAK is verantwoordelijk voor de uitvoering van de regeling, die wordt betaald uit de begroting van VWS. Voor beide vormen van zorg krijgt een zorgaanbieder bovendien alleen kosten vergoed indien aan de volgende voorwaarden is voldaan: ${ }^{56}$

1. Er moet sprake zijn van een (gedeeltelijk) onbetaalde rekening. Als de verschuldigde kosten door of namens de patiënt kunnen worden betaald, kan een zorgaanbieder geen beroep doen op de regeling;

2. De patiënt is onverzekerd én onverzekerbaar als gevolg van de Koppelingswet; 3. Het moet gaan om medisch noodzakelijke zorg. Onder medisch noodzakelijke zorg wordt verstaan zorg of diensten die onderdeel zijn van het basiszorgpakket van Zvw (met uitzondering van ivf en genderoperaties ${ }^{57}$ ) of de Wlz;

4. De zorgaanbieder bepaalt of de verleende zorg medisch noodzakelijk was, gezien de aard van de prestatie en de verwachte duur van het verblijf;

5. De kosten kunnen niet op grond van een andere wettelijke bepaling worden vergoed en zijn in de Nederlandse marktomstandigheden 'in redelijkheid passend'.

Zorg verleend rond zwangerschap en bevalling wordt voor $100 \%$ vergoed. ${ }^{58}$ Daarnaast hebben niet rechtmatig verblijvende kinderen toegang tot preventieve jeugdgezondheidszorg en tot het vaccinaties overeenkomstig het rijksvaccinatieprogramma.

De regeling geldt niet voor Nederlanders, inwoners van Aruba, Curaçao en St. Maarten, EU-onderdanen en inwoners van IJsland, Noorwegen, Liechtenstein en Zwitserland.

In 2014 is de zogenoemde 5-euro-maatregel ingevoerd. Iedere onverzekerbare vreemdeling dient sindsdien minimaal $€ 5$,- per receptregel aan eigen bijdrage te betalen aan de apotheker bij de uitgifte van de medicatie. Deze maatregel werd ingevoerd omdat bleek dat onverzekerbare vreemdelingen bij uitgifte van medicijnen niet of nauwelijks zelf de rekening betaalden, omdat zij bekend waren met het bestaan van de regeling. ${ }^{59}$

Het CAK controleert of aan de voorwaarden is voldaan, betaalt de declaraties, monitort de omvang van de kosten en verzorgt de voorlichting.

\footnotetext{
${ }^{54}$ Art. 122a lid 4 Zvw.

55 Art. 122a lid $5 \mathrm{Zvw}$.

${ }^{56}$ Art. 122a leden 2-4 Zvw.

${ }^{57}$ Dit is bepaald in art. $3 b .1$ van het Besluit zorgverzekering.

${ }^{58}$ Art. 122a lid 4a Zvw.

${ }^{59} \mathrm{ZiNL}, 7 \mathrm{e}$ monitor Regeling financiering zorg onverzekerbare vreemdelingen, 24 mei 2013.
} 
Het ZiNL bracht ieder jaar een monitor uit waarin onder meer werd ingegaan op de kosten van de medische zorg aan onverzekerde vreemdelingen, vergoed door de bijdrageregeling. ${ }^{60}$ Tegenwoordig wordt over de regeling verslag gedaan in de VWSVerzekerdenmonitor. ${ }^{61}$ De zorg- en uitvoeringskosten worden opgenomen in de VWSbegroting. De financiële middelen voor 2020 voor de bijdrageregeling betreffen $€ 32,4$ miljoen. $^{62}$

In 2018 had het CAK 31 ziekenhuizen gecontracteerd voor algemene medisch specialistische zorg. ${ }^{63}$ Daarnaast waren 38 instellingen voor ziekenhuiszorg gecontracteerd voor doorverwijzingen van bijzondere zorgvragen (gespecialiseerd en specifiek zorgaanbod zoals revalidatiezorg). Voor ambulancevervoer en ziekenvervoer is een landelijke overeenkomst afgesloten. ${ }^{64}$

\subsubsection{Exit Wlz-zorg? En andere besparingsvarianten.}

Het vergoeden van langdurige zorg is omstreden gelet op het criterium 'medisch noodzakelijk'. ${ }^{65}$ In 2018 is onderzocht op welke wijze bespaard zou kunnen worden op de bijdrageregeling. Het uitsluiten van Wlz-zorg van de bijdrageregeling zou een besparing van 2,5 miljoen per jaar opleveren. Risico daarbij zou zijn dat een vreemdeling die een Wlzindicatie krijgt in het ziekenhuis zou blijven liggen waar hij behandeld wordt, omdat hij niet zou kunnen worden overgedragen. De beleidsdoorlichting formuleert vier besparingsmogelijkheden voor de bijdrageregeling, die in de Beleidsdoorlichting als stimuleringsmaatregel worden gekwalificeerd. ${ }^{66}$ De volgende besparingsmaatregelen werden overwogen: ${ }^{67}$

1. Uitsluiten van de Wlz-zorg. Achterliggende gedachte bij deze bezuinigingsmaatregel is dat het bieden van langdurige zorg - gelet op het medisch noodzakelijkheidscriterium controversieel is. In naburige landen zou medisch noodzakelijke zorg in het algemeen alleen curatieve zorg betreffen. ${ }^{68}$

2. Aanpassen van de vergoedingspercentages. De vergoedingspercentages zouden naar beneden bijgesteld kunnen worden. Een verlaging van $80 \%$ naar $70 \%$ zou bijvoorbeeld een besparing van $€ 8,6$ miljoen opleveren.

3. Uitbreiden van de vijf-euro-maatregel.

\footnotetext{
${ }^{60}$ De laatste was ZiNL, 9e monitor Regeling financiering zorg onverzekerbare vreemdelingen, 8 oktober 2015.

${ }^{61}$ Onder de monitor vallen ook andere bijzondere groepen zoals gemoedsbezwaarden en de subsidieregeling medisch noodzakelijke zorg aan onverzekerden. De VWS-Verzekerdenmonitor gebruikt overigens nog steeds de terminologie 'illegalen', VWS-Verzekerdenmonitor 2019, Den Haag: 2019, p. 24.

${ }^{62}$ Beleidsdoorlichting van artikel 2.2 van de VWS-Begroting 'Toegankelijkheid en betaalbaarheid van de zorg', VWS, Directoraat Curatieve Zorg, 2018 ('Beleidsdoorlichting VWS 2018'), p. 25.

${ }^{63}$ Op de website van het CAK staat een actuele lijst met gecontracteerde ziekenhuizen, hetcak.nl.

${ }^{64}$ Beleidsdoorlichting VWS 2018 (supra noot 62), p. 23. Zie ook par. 9.3.3 van dit proefschrift.

${ }^{65}$ Zie par. 5.8 van dit proefschrift.

${ }^{66}$ Beleidsdoorlichting VWS 2018 (supra noot 62), p. 17.

${ }^{67}$ Beleidsdoorlichting VWS 2018 (supra noot 62), p. 27-28.

${ }^{68}$ De aanspraken op gezondheidszorg in andere EU-landen variëren van uitsluitend medisch urgente zorg tot langdurige zorg. Een overzicht van aanspraken op gezondheidszorg in de EU-landen (2016) is te vinden op fra.europa.eu.
} 
4. Aanpassing vergoeding huisartsen. Huisartsen ontvangen niet het normale abonnementstarief, maar het passententarief, dat beduidend hoger ligt.

De minister voor Medische Zorg en Sport (Bruijns) vond de voorgestelde besparingsmaatregel echter haaks staan op het gevoerde beleid dat gericht is op toegankelijkheid van zorg. Met iedere variant zou de verplichting om toegankelijke zorg te verlenen op de een of andere manier in het gedrang komen. Mede gelet op de verplichtingen die voortvloeien uit internationale verdragen, achtte hij het onwenselijk om deze besparingsmogelijkheid uit te voeren. ${ }^{69}$

\subsubsection{Aard van de aanspraak}

Alleen zorgaanbieders kunnen een beroep doen op de bijdrageregeling. De vreemdeling heeft dus geen verzekeringsaanspraak. De vergoedingsregeling is volgens de overheid niet bedoeld als 'semi-verzekering voor betrokkenen, maar als een financiële bijdrage voor zorgaanbieders die medisch noodzakelijke zorg hebben verleend aan in betalingsonmacht verkerende vreemdelingen en dientengevolge inkomsten derven' ${ }^{70}$ De uitzondering van artikel 10 lid 2 Vw ('van het eerste lid kan worden afgeweken indien de aanspraak betrekking heeft op het onderwijs, de verlening van medische noodzakelijke zorg, de voorkoming van inbreuken op de volksgezondheid, of de rechtsbijstand aan de vreemdeling') houdt voor wat betreft de medisch noodzakelijke zorg niet in dat er een eigenstandige aanspraak van de verzekerde bestaat.

Eerder betoogden Sijmons en ik dat een uitzondering op het 'ontkoppelingsbeginsel' zou moeten inhouden dat niet de zorgaanbieder recht heeft op een gedeeltelijke vergoeding, maar dat de medisch noodzakelijke zorg wel verzekerd zou moeten zijn met een eigen aanspraak. ${ }^{71}$ De verwijzing in artikel $122 \mathrm{a}$ Zvw naar artikel $10 \mathrm{Vw}$ doet volgens ons vermoeden dat er een eigen aanspraak is gecreëerd, wat niet het geval is. Verwezen had moeten worden naar 'vreemdelingen zonder rechtmatig verblijf als bedoeld in artikel 8 Vreemdelingenwet'. Door de vergoedingsregeling is een 'naturamodel zonder verzekeringsaanspraak' gecreëerd. Het is niet een bestuursorgaan, maar de zorgverlener die over de aanspraak beslist. Dit doet hij op eigen risico, deels voor eigen rekening en op grond van een onheldere norm van 'noodzakelijkheid'. Annotator Minderhoud volgt deze gedachtegang. Ook hij is van mening dat de in artikel 10 lid $2 \mathrm{Vw}$ vermelde aanspraak op medisch noodzakelijke zorg niet meer is dan een lege huls, omdat deze aanspraak niet is geconcretiseerd in de Zvw en Wlz (destijds AWBZ). Het recht op medisch noodzakelijke zorg is volgens hem nergens in de nationale regelgeving adequaat uitgewerkt. ${ }^{72}$ Als zorgverleners de medisch noodzakelijke zorg weigeren te verlenen, dient deze zorg bij de rechter te worden afgedwongen met een beroep op internationaalrechtelijke verplichtingen. Annotator Hallie daarentegen is van mening dat de

\footnotetext{
${ }^{69}$ Brief van de Minister voor Medische Zorg en Sport aan de Voorzitter van de Tweede Kamer, 30 maart 2018 , 1322178-174975-Z.

${ }^{70}$ Kamerstukken II 2007/08, 31 249, nr. 3, p. 2.

${ }^{71}$ Sijmons \& Derckx, NJB 2010/27, p. 1398-1456.

72 P.E. Minderhoud, annotatie bij CRvB 20 oktober 2010, ECLI:NL:CRVB:2010:B03581, JV 2011/90. In deze zaak ging het over een kind met een autistische stoornis en een verstandelijke beperking, dat rechtmatig in Nederland verbleef in afwachting van bezwaar tegen de afwijzing van een verblijfsvergunning. Hem werd extra zorg geweigerd, bestaande uit onder andere activerende en ondersteunende begeleiding. Met een beroep op art. 8 EVRM diende art. 5 lid 2 AWBZ volgens de Centrale Raad buiten toepassing te worden gelaten. Minderhoud vraagt zich in zijn annotatie af of de Centrale Raad art. 10 lid 2 Vw hier wel goed toepast.
} 
verdragsverplichtingen de staat niet dwingen om de toegang tot medische zorg in de vorm van toelating tot een verzekering te gieten. Toegang tot zorg kan volgens haar ook buiten de Zvw en Wlz (toen: AWBZ) om geregeld worden. Volgens de verdragsverplichtingen dient noodzakelijke zorg te worden geleverd, maar dat hoeft niet kosteloos te gebeuren. Volgens haar is de noodzakelijke medische zorg voor vreemdelingen feitelijk gewaarborgd. ${ }^{73}$

\subsection{Overige relevante (financierings)regelingen voor vreemdelingen}

\subsubsection{Regeling Medische zorg Asielzoekers}

Asielzoekers en vluchtelingen die in een COA-opvanglocatie verblijven, vallen onder de RMA. ${ }^{74}$ Het is relevant het verschil tussen de RMA en de bijdrageregeling te bespreken, omdat de RMA buitenwettelijk van toepassing is op onrechtmatig verblijvende minderjarigen (zie 4.5.3).

De RMA vindt zijn grondslag in de eerder genoemde Rva 2005. De Rva 2005 is op haar beurt een uitwerking van de EU-Opvangrichtlijn. ${ }^{75}$ Niet alleen asielzoekers, maar ook aan asielzoekers gelijkgestelde categorieën vreemdelingen vallen onder de Regeling. ${ }^{76}$

Volgens de Rva 2005 omvat de opvang in een opvangvoorziening de dekking van de kosten van medische verstrekkingen overeenkomstig een daartoe te treffen ziektekostenregeling. ${ }^{77}$ Dit houdt in het afsluiten van een ziektekostencontract ter dekking van de kosten van het door de minister van Justitie en Veiligheid (JenV) vastgestelde pakket medische verstrekkingen. Dit is uitgewerkt in de RMA, uitgevoerd door RMA Healthcare. RMA Healthcare organiseert en vergoedt de medische zorg voor asielzoekers.

De RMA omschrijft op welke zorg asielzoekers (in de regeling 'verzekerden' genoemd) aanspraak hebben. Het gaat om een aanspraak op zorg in natura. Er bestaat enkel recht op vergoeding van zorg door zorgaanbieders die een contract hebben met RMA Healthcare. De RMA omschrijft de aanspraken op zorg en de voorwaarden daarvoor per zorgsoort. Het merendeel van de aanspraken onder de RMA komt overeen met de aanspraken in het basispakket van de Zvw. In tegenstelling tot de Zvw, bestaat er aanspraak op een tolk.

De RMA kent vergoeding toe aan een aantal verstrekkingen die niet onder het basispakket vallen, zoals mondzorg voor volwassenen, fysiotherapie en hoortoestellen. Daarentegen zijn er ook verstrekkingen uitgesloten die wel onder het basispakket van de Zvw vallen, zoals bijvoorbeeld cochleaire implantaten (gehoorimplantaten), sterilisatie en operatieve ingrepen in het kader van transseksualiteit. ${ }^{78}$

De achtergrond van deze uitzonderingen is niet in de wetsgeschiedenis toegelicht. Volgens de Minister van JenV is de ratio van deze uitzonderingen dat het gaat om behan-

\footnotetext{
${ }^{73}$ J. Hallie, annotatie bij Rb. Zwolle-Lelystad 5 juli 2011, ECLI:NL:RBZLY:2011:BU4862, RZA 2011/124.

${ }^{74}$ RMA, versie 10 juli 2019. De meest recente versie is te raadplegen via rmasielzoekers.nl.

${ }^{75}$ Deze richtlijn harmoniseert de voorwaarden en omstandigheden van de opvang van asielzoekers, zie hoofdstuk 6.

${ }^{76}$ Art. 2 lid 1 jo art. 3 leden 3 en 4 Rva 2005.

${ }^{77}$ Art. 9 lid 1 sub e Rva 2005.

${ }^{78}$ Art. 2.19 RMA.
} 
delingen die vanwege de verblijfsrechtelijke status van de vreemdeling naar verwachting niet in Nederland kunnen worden voltooid. ${ }^{79}$

\subsubsection{Regeling verstrekkingen bepaalde categorieën vreemdelingen}

Voor bepaalde categorieën vreemdelingen die niet in aanmerking komen voor een asielprocedure en die rechtmatig in Nederland verblijven, is de Regeling verstrekkingen bepaalde categorieën vreemdelingen (Rvb) opgesteld. ${ }^{80}$ Ratio van de Rvb was dat het door de inwerkingtreding van de Koppelingswet onwenselijk was als bepaalde groepen vreemdelingen niet langer aanspraak konden maken op noodzakelijke bestaansvoorwaarden. Op grond van de $\mathrm{Rvb}$ is een ziektekostenverzekering mogelijk. De regeling geldt voor slachtoffers en (getuige)aangevers van mensenhandel, slachtoffers van mensenhandel aan wie op grond hiervan een verblijfsvergunning is verleend en die in Nederland verblijven met één of meer minderjarige kinderen, gezinsherenigers, niet-alleenstaande minderjarigen en vreemdelingen die in een instelling voor vrouwenopvang verblijven in verband met eer gerelateerd geweld. ${ }^{81}$ De uitvoering hiervan ligt bij het COA. Het COA kan een financiële toelage of de dekking van kosten van medische verstrekkingen weigeren indien op andere grond dan de Rvb in de noodzakelijke bestaansvoorwaarden wordt of is voorzien, bijvoorbeeld als de vreemdeling al verstrekkingen ontvangt om in de noodzakelijke bestaansvoorwaarden te voorzien omdat hij verblijft of, in de periode waarvoor de financiële toelage is gevraagd, verbleef in een gezinslocatie of een azc of omdat er al een gemeentelijke uitkering wordt verstrekt. ${ }^{82}$

\subsubsection{Financiering van medische zorg in opvanglocaties}

Gezinnen met kinderen die niet uit Nederland vertrekken, hebben geen recht (meer) op opvang in een opvanglocatie van het COA. Zij vallen niet meer onder de Rva 2005. Zij kunnen worden overgeplaatst naar een Vrijheidsbeperkende Locatie (VBL), bij zicht op terugkeer naar land van herkomst of een gezinslocatie. De RZA, de ziektekostenregeling voor asielzoekers die recht hebben op opvang vanwege het COA, wordt op gelijke wijze toegepast op minderjarige kinderen zonder rechtmatig verblijf die verblijven in een gezinslocatie. ${ }^{83}$ Dat is een vaste gedragslijn die op één lijn te stellen is met buitenwettelijk begunstigend beleid. ${ }^{84}$ Minderjarige kinderen in gezinslocaties hebben dientengevolge recht op dezelfde medische zorg als kinderen in een regulier asielzoekerscentrum. Het grootste deel van de aanspraken onder de RMA komt overeen met de aanspraken in het basispakket van de Zvw. Daarnaast valt een deel van de zorg die regulier voortvloeit uit de Wmo, de Wlz en de Jeugdwet, ook onder de RMA. De ouders hebben recht op medisch noodzakelijke zorg volgens de bijdrageregeling. Het van toepassing

\footnotetext{
${ }^{79}$ Rb. Den Haag 5 oktober 2016, ECLI:NL:RBDHA:2016:12328, r.o. 4.1. In deze zaak ging het om vergoeding van een cochleair implantaat $(\mathrm{CI})$. De implantatie van een CI kent een langdurig traject van nazorg en begeleiding en daarnaast is technisch onderhoud van het CI zelf noodzakelijk. Hierover uitvoeriger par. 9.4.3 van dit proefschrift.

${ }^{80}$ Regeling verstrekkingen bepaalde categorieën vreemdelingen 2005 (Rvb).

${ }^{81}$ Art. 1 lid 1 sub a-h Rvb.

${ }^{82}$ Art. 3 lid 4 Rvb.

${ }^{83}$ Zie Kamerstukken II 2011-2012, 29 344, nr. 85, p. 4.

${ }^{84}$ Rb. Den Haag 5 oktober 2016, ECLI:NL:RBDHA:2016:12328, r.o. 4.3.
} 
zijn van de RMA op onrechtmatig verblijvende minderjarige kinderen kan problematisch zijn (zie hoofdstuk negen).

\subsubsection{Financiering van medische zorg voor vreemdelingen in detentiecentra}

Vreemdelingen die in vreemdelingenbewaring verblijven tenslotte, vallen onder de Penitentiaire Beginselwet (PBW). ${ }^{85}$ Vreemdelingen vallen onder hetzelfde regime als regulier strafrechtelijk gedetineerden. De directeur van het detentiecentrum is verantwoordelijk voor de toegang tot de zorg. ${ }^{86}$ De medische zorg die wordt aangeboden is gelijkwaardig aan de reguliere gezondheidszorg, tenzij de zorg kan worden uitgesteld tot na het verblijf in detentie. Vreemdelingen die zijn gedetineerd in detentiecentrum Schiphol vallen onder het Reglement regime grenslogies. ${ }^{87}$ De directeur dient zorg te dragen voor de verlening van de noodzakelijke medische hulp. ${ }^{88}$ De toegang tot de medische zorg in detentiecentra en de kwaliteit ervan zijn van groot belang voor de gezondheid van de onrechtmatig verblijvende vreemdeling, maar worden in dit proefschrift niet nader onderzocht. ${ }^{89}$

\subsection{Conclusie}

Door het koppelingsbeginsel zijn onrechtmatig verblijvende vreemdelingen uitgesloten van sociale verzekeringen. Door de differentiatie in categorieën vreemdelingen is sprake van een complexe waaier aan toepasselijke regelingen. Daarnaast kennen zowel de Wlz als het Besluit uitbreiding en beperking kring verzekerden volksverzekeringen uitzonderingen op het koppelingsbeginsel of kunnen deze geven. Buiten deze uitzonderingen geldt de bijdrageregeling ex artikel 122a Zvw. Deze geeft onverzekerbare vreemdelingen geen zelfstandige aanspraak op zorg, maar vergoedt onder bepaalde voorwaarden onbetaald gebleven rekeningen voor verleende medische zorg aan de zorgverlener. De indirecte vormgeving van de oorspronkelijke regeling is met de bijdrageregeling gewijzigd in een wettelijk verankerde regeling. Daarmee erkent de overheid nu expliciet de verplichting om te zorgen voor toegankelijkheid van zorg uit hoofde van internationale verdragen. Om die reden heeft de minister ook (nog) niet bezuinigd op de regeling. De omvang van het recht op zorg is aan de zorgverlener overgelaten. Deze bepaalt of de zorg medisch noodzakelijk is. Het volgende hoofdstuk gaat over dit cruciale begrip.

\footnotetext{
${ }^{85}$ Wet van 18 juni 1998 tot vaststelling van een Penitentiaire beginselenwet en daarmee verband houdende intrekking van de Beginselenwet gevangeniswezen met uitzondering van de artikelen 2 tot en met 5 en wijzigingen van het Wetboek van Strafrecht en het Wetboek van Strafvordering alsmede enige andere wetten (Penitentiaire beginselenwet),

${ }^{86}$ Art. 42 PBW.

${ }^{87}$ Besluit van 14 januari 1993, houdende vaststelling van een reglement voor het regime in een grenslogies ingevolge art. 7a, vierde lid, Vreemdelingenwet.

${ }^{88}$ Art. 8 sub c Reglement.

${ }^{89}$ Verwezen zij naar Amnesty International 2013, Nationale ombudsman 2013, Werkgroep medische zorg in vreemdelingendetentie 2014, IGZ 2014, Hendriks \& Toebes, NJB 2016/19, p. 1347-1352.
} 


\title{
Hoofdstuk 5 Medisch noodzakelijke zorg
}

\author{
Het Landelijk informatie- en adviespunt over de \\ zorg aan ongedocumenteerden (Lampion) \\ verstrekt onder meer advies over zorgverlening aan \\ ongedocumenteerden. De volgende casus werd \\ aan Lampion voorgelegd door een vrijwilligster van \\ een welzijnsorganisatie. Een ongedocumenteerde \\ man heeft een been dat helemaal openligt. De \\ wond is al geïnfecteerd. De huisarts van deze man \\ heeft tegen de vrijwilligster gezegd dat ze niks kan \\ doen. Het ziekenhuis kan de man pas opnemen als \\ het been geamputeerd moet worden. De huisarts \\ geeft aan dat, als het om een van haar eigen \\ patiënten met dezelfde klachten zou gaan, zij hem \\ direct zou laten opnemen en aan een antibiotica- \\ infuus zou laten leggen. \\ Bron: Voogt en Mensinga, Vakblad Sociaal Werk \\ 2019, afl. 6, p. 23-25.
}

\subsection{Inleiding}

Dit hoofdstuk richt zich op de vraag wat wordt verstaan onder medisch noodzakelijke zorg in de context van de bijdrageregeling en hoe dit begrip zich verhoudt tot de hulpverleningsplicht van de zorgverlener. Samen met het vorige hoofdstuk beoogt het een antwoord te geven op deelvraag 2 ('hoe zijn deze aanspraken concreet vormgegeven in het Nederlandse systeem?').

Als waarborg van de feitelijke toegang tot zorg van onrechtmatig verblijvende vreemdelingen zag en ziet de wetgever de individuele zorgplicht van de hulpverlener. Achterliggende gedachte is dat artsen en andere hulpverleners op grond van hun professionele verantwoordelijkheid verplicht zijn om indien nodig medisch noodzakelijke zorg te verlenen, ongeacht de vraag of en hoe de kosten van die zorgverlening zullen worden vergoed. ${ }^{1}$ Deze hypothese wordt in dit hoofdstuk getoetst. Daartoe wordt in de eerste plaats nagegaan wat de term 'medisch noodzakelijke zorg' inhoudt. Dit is geen statisch, maar een dynamisch begrip gebleken. In de tweede plaats vindt een analyse plaats van de ethische en juridische grondslagen en de reikwijdte van de zorgplicht van artsen en tandartsen. Bestudeerd wordt wat de verhouding van deze hulpverleningsplicht is tot het begrip medisch noodzakelijke zorg.

Naast de zorgplicht van de artsen staat de plicht van de staat om medische zorg te verlenen aan een ieder die op haar grondgebied verblijft. De reikwijdte van deze plicht komt

\footnotetext{
${ }^{1}$ Onder meer Beleidsdoorlichting VWS 2018, p. 5.
} 
aan de orde in hoofdstuk zes.

De opbouw van dit hoofdstuk is als volgt. Het eerste deel beschrijft de parlementaire geschiedenis van de Koppelingswet ten aanzien van het begrip medisch noodzakelijke zorg. Diverse commissies hebben zich vóór, tijdens en na de parlementaire behandeling van het wetsontwerp Koppelingswet gebogen over de vraag wat onder 'medisch noodzakelijke zorg' dient te worden verstaan. Deze respectievelijke bevindingen worden besproken, evenals de onduidelijkheid die na de inwerkingtreding van de Koppelingswet over dit begrip bleef bestaan. Het tweede deel onderzoekt op welke wijze beroepsgroepen het begrip hebben ingevuld in richtlijnen. Vervolgens wordt ingezoomd op de hulpverleningsplicht van arts en tandarts, die deel uitmaakt van de medisch-professionele standaard. Deze hulpverleningsplicht kent twee componenten: een medisch-ethische en een juridische. Beide komen aan bod.

\section{2 (Parlementaire) voorgeschiedenis: van 'acute noodsituaties' tot 'medisch noodzakelijke zorg'}

\subsubsection{Inleiding}

Deze paragraaf gaat in op de parlementaire achtergrond van de wijziging van het aanvankelijk in het wetsvoorstel Koppelingswet opgenomen begrip 'acute medische noodsituaties' in 'medisch noodzakelijke zorg'. ${ }^{2}$ De overwegingen die aan deze wijziging ten grondslag hebben gelegen geven inzicht in verschillende opvattingen die er bestonden en nog steeds bestaan over de reikwijdte van het recht op zorg van de onrechtmatig verblijvende vreemdeling.

\subsubsection{Commissie Zeevalking/wetsontwerp Koppelingswet: 'acute medische noodsituaties'}

Zoals al vermeld in paragraaf 3.2.2.2, lag aan de aanvankelijke formulering 'acute medische noodzakelijke zorg' in het wetsvoorstel Koppelingswet het advies van de commissie Zeevalking ten grondslag. Het zij hier nog eens herhaald: de commissie achtte verstrekking van collectieve voorzieningen noodzakelijk in gevallen waarin de vreemdeling zich in een acute noodsituatie bevindt, of in gevallen waarbij zwaarwegende Nederlandse belangen, resp. internationale verplichtingen in het geding zijn. Onder 'acute noodsituatie' verstond de commissie 'een plotseling opkomende omstandigheid, sterk gelimiteerd in tijd, die de verstrekking van de voorziening essentieel maakt voor de fysieke, psychische of economische gesteldheid van de vreemdeling. ${ }^{3}$ Zo zal volgens de commissie aan de illegaal verblijvende vreemdeling, die op straat wordt aangereden, moeilijk hulp kunnen worden geweigerd omdat hij illegaal in Nederland verblijft. De commissie veronderstelde daarbij ziekenhuizen vanwege bezuinigingen alleen medische hulp zouden verlenen bij levensbedreigende situaties. Bij 'zwaarwegende Nederlandse belangen' dacht de commissie vooral aan de gezondheidszorg. In het kader van preventie van besmettelijke ziektes en van drugsbestrijding achtte de commissie een goede toegankelijkheid van de gezondheidzorg voor een ieder die in Nederland verblijft van zwaarwegend Nederlands belang. Zo achtte de commissie het ongewenst dat wanneer contact met de huisarts zou worden vermeden, terwijl dit juist duurdere hulpverlening in een

\footnotetext{
${ }^{2}$ Zie eerder par. 3.3.4.3.

${ }^{3}$ Commissie Zeevalking 1991, p. 20 (par. 12).
} 
later stadium zou kunnen voorkomen. In deze visie is sprake van een beperkt recht op zorg voor de gezondheid. Redelijke toegankelijkheid van de eerstelijnsgezondheidszorg waarvan in de praktijk al sprake leek te zijn, hing volgens de commissie vooral samen met de bereidheid van hulpverleners laagdrempelige hulpverlening te bieden.

De visie van de commissie Zeevalking kwam terug in de nota 'Gezond en Wel' uit 1995, die spreekt van 'hulpverlening in acute noodsituaties'. ${ }^{4}$ Vormen van gezondheidszorg zouden volgens de nota 'in bijzondere omstandigheden en onder strikte voorwaarden' toegankelijk zijn voor illegalen. Dit betrof dan vooral de bestrijding van sommige infectieziekten (tbc) en hulpverlening in acute noodsituaties, als sprake is van ogenblikkelijk levensgevaar of een acute en vitale hulpeloze toestand.

De Ziekenfondsraad daarentegen stelde zich in zijn respectievelijke adviezen op het standpunt dat ook voor illegale vreemdelingen de toegang tot de noodzakelijke medische zorg gewaarborgd diende te zijn. Dit was breder dan 'acute noodsituaties'. Noodzakelijke medische zorg diende volgens de Raad gewaarborgd te zijn en door de overheid te worden bekostigd. Dit zowel vanuit het maatschappelijk perspectief om illegalen niet verstoken te laten van noodzakelijke medische zorg, als vanwege de aanzienlijke gezondheidsrisico's die voor anderen kunnen ontstaan als ziekten niet worden behandeld. ${ }^{5}$

Aanvankelijk was in het wetsontwerp Koppelingswet voorzien in overheidsfinanciering voor zorg verleend in 'acute medische noodsituaties'. ${ }^{6}$ Hieronder werd verstaan situaties waarin sprake is van ogenblikkelijk levensgevaar of een acute of vitale hulpeloze toestand, waarbij verlening van medische zorg niet kan worden uitgesteld zonder het leven of de gezondheidstoestand van de betrokkene ernstig in gevaar te brengen, dan wel in gevallen waarin een algemeen volksgezondheidsbelang werd gediend. ${ }^{7}$ In de voorwaarden voor vergoeding uit het koppelingsfonds werd nog toegevoegd dat het moest gaan om adequate en onvermijdelijke medische zorg. ${ }^{8}$

\subsubsection{Kritiek op formulering 'acute medische noodsituaties'}

De NRV concludeerde in het al eerder genoemde advies (paragraaf 3.4) dat het gebruik van verschillende begrippen en de verschillende interpretaties ervan in de praktijk tot moeilijkheden en verschillen zou kunnen leiden. ${ }^{9}$ Het feit dat de invulling van deze begrippen aan hulpverleners werd overgelaten, droeg volgens de raad niet bij aan de duidelijkheid ervan. De raad plaatste vervolgens kanttekeningen bij zowel a. het begrip 'acute medische zorg', als b. het begrip 'noodzakelijke zorg'. ${ }^{10}$

Ad a: Acuut kon volgens de raad zowel slaan op het afwenden van levensbedreiging, de snelheid waarmee gehandeld moet worden, als op het onderscheid acuut/chronisch. Of een

\footnotetext{
${ }^{4}$ Ministerie van VWS, Nota Gezond en Wel. Rijswijk, Kamerstukken II 1994/95, 24 126, nr. 2 p. 13. De nota 'Gezond en Wel' zag op het volksgezondheidbeleid van 1995/98.

${ }^{5}$ Ziekenfondsraad 1992, Ziekenfondsraad 1995, p. 12.

${ }^{6}$ Kamerstukken II 1994/95, 24 233, nr. 3, p. 19.

${ }^{7}$ Kamerstukken II 1995/96, 24 233, nr. 4, p. 22.

${ }^{8}$ Zie voor de overige voorwaarden par. 4.3.2.1.

9 De NRV doelde hier op de begrippen 'acute noodsituaties', 'levensbedreiging' en 'noodzakelijke zorg', NRV 1995, p. 16.

${ }^{10}$ NRV 1995, p. 17-18.
} 
gezondheidssituatie levensbedreigend is kon betrekking hebben op:

- directe levensbedreiging;

- levensbedreiging op termijn;

- potentiële levensbedreiging;

- levensbedreiging indien bepaalde vormen van behandeling of zorg niet worden genoten.

Ad b: Onder noodzakelijke zorg kon volgens de raad worden verstaan:

- zorg in een acute situatie, onontkoombare, niet te weigeren zorg;

- zorg, zoals noodzakelijk wordt geacht door de beroepsgroep, of zoals gebruikelijk door de beroepsgroep wordt verleend, informeel geïndiceerde zorg;

- zorg, zoals noodzakelijk geacht volgens het Dunning-criterium, zorg behorend tot het basispakket;

- zorg, zoals vastgelegd in het verzekeringspakket, formeel geïndiceerde zorg.

De NRV formuleerde vervolgens drie situaties als toetsingscriteria voor de beoordeling van de noodzakelijkheid van de zorg. ${ }^{11}$ Volgens de NRV diende de zorgverlening in ieder geval mogelijk te zijn in:

1. Situaties van (acute) levensbedreiging, ook voor derden. Hieronder moet ook potentiële levensbedreiging op afzienbare termijn begrepen worden, wanneer mensen van medische hulp verstoken blijven. Gevaar voor derden is in het geding bij de tbcbestrijding en bij gedwongen opname in het kader van de (toenmalige) Wet Bopz, die volgens de NRV ook van toepassing was bij gevaar voor de persoon zelf.

2. Situaties van acute bedreiging van essentiële functies, niet direct levensbedreigend maar wel leidend tot blijvende functiebeperkingen.

3. Alle situaties waarin zorg aan illegaal verblijvende kinderen verleend moet worden, inclusief prenatale zorg, zwangerschapszorg en postnatale zorg. Dit op grond van de overweging dat kinderen voor hun illegale status niet verantwoordelijk zijn en de ondertekening van het Verdrag inzake de rechten van het kind dit vereist.

Deze drie situaties verwoordden steeds een verschillende dimensie van het noodzakelijkheidsprincipe. Daarnaast adviseerde de NRV om vormen van zorg die duidelijk het ontstaan van acute levensbedreiging en acute bedreiging van essentiële functies rechtstreeks kunnen voorkomen, mogelijk te laten zijn. Dit uit preventieve (kosten)overwegingen. Dit zou volgens de NRV vooral te realiseren zijn door een goede toegankelijkheid van de eerstelijnszorg, de eerste hulp en de GGD-en.

De NRV voegde daar nog aan toe dat het uit humanitair oogpunt toe te juichen zou zijn indien de overheid meer zorg zou willen regelen dan de door de NRV voorgestelde situaties. ${ }^{12}$

De Vereniging voor Volksgezondheid en Wetenschap (V\&W) achtte de interpretatie van het begrip 'noodzakelijke zorg' door de wetgever (te weten de bestrijding van sommige infectieziekten en hulpverlening in acute noodsituaties, als sprake is van ogenblikkelijk

\footnotetext{
${ }^{11}$ NRV 1995, p. 35.

${ }^{12}$ NRV 1995, p. 36.
} 
levensgevaar of een acute en vitale hulpeloze toestand) onvoldoende in het licht van de internationale verdragen en de bestaande wetgeving. ${ }^{13}$ In navolging van de commissie Zeevalking en de NRV stelde de V\&W een drietal situaties voor waarin de zorg aan illegalen mogelijk en toegankelijk moest zijn:

1. Situaties van levensbedreiging of dreiging van het verlies van essentiële functies, leidend tot blijvende functiebeperkingen.

2. Situaties waarin zich een gevaar voor derden voordoet. Dit geldt bijvoorbeeld voor bepaalde infectieziekten (in het bijzonder tbc) en bij psychische stoornissen die gepaard gaan met agressief gedrag.

\section{Situaties waarin zorg verleend moet worden voor (ongeboren) kinderen.}

Het eerste criterium diende ruim te worden geïnterpreteerd, dat wil zeggen vormen van zorg te omvatten die het ontstaan van levensbedreiging en bedreiging van essentiële functies kunnen voorkomen, mede op grond van de overweging dat hiermee kosten in de toekomst vermeden kunnen worden. Daarnaast bepleitte V\&W een onbeperkte toegang tot de huisartsenzorg. ${ }^{14}$

In (gezondheidsrechtelijke) literatuur werden principiële bezwaren geuit tegen de formulering 'acute noodsituatie'. Gevers had kritiek op de interpretatie van noodsituatie als alleen acuut en ernstig gevaar voor leven of gezondheid. Hij wees op potentiële levensbedreiging op termijn, of risico's van blijvende functiebeperkingen. ${ }^{15}$ Hendriks kwalificeerde de verplichting om medische zorg te verlenen slechts in acute medische noodsituaties als een inperking van het recht op gezondheid en in strijd met de kerninhoud van dit recht. Er zou onvoldoende rekening worden gehouden met zowel het bestaan als het afwenden van ernstige risico's voor de gezondheid van illegale vreemdelingen. Daarnaast zou de definitie 'acute noodsituatie' onvoldoende rekening houden met de gezondheidsbelangen van vrouwen en kinderen en zou er spanning zijn met internationale verdragen. ${ }^{16}$ Toebes tenslotte plaatste kanttekeningen bij de gevallen die werden gecategoriseerd onder 'gevaar voor derden'. Deze zorg strekt immers niet alleen ter bescherming van de Nederlandse bevolking (of in het geval van zwangerschap: van het ongeboren kind), maar ook ter bescherming van de vreemdeling zelf. Bovendien was de lijst verrichtingen volgens Toebes niet limitatief: ook het nalaten van andere verrichtingen zou ernstige en soms onomkeerbare schade kunnen toebrengen. Hierbij dacht ze aan het verlenen van psychische zorg aan onrechtmatig verblijvende vreemdelingen die geen gevaar voor derden vormen en preventieve geneeskundige hulp waarbij geen sprake is van acute medische nood. ${ }^{17}$

De uitwerking van het begrip 'acute medische noodsituaties' riep ook bij Kamerleden vragen op. Er bestond behoefte aan opheldering en voorbeelden. ${ }^{18}$ In antwoord op deze vragen verwees de regering voor de interpretatie van het begrip naar de voorwaarden waaronder tot

\footnotetext{
${ }^{13}$ V\&W 1996, p. 5.

${ }^{14} \mathrm{~V} \& \mathrm{~W} 1996$.

${ }^{15}$ Gevers, TvGR 1996/3, p. 121.

${ }^{16}$ Hendriks, Migrantenrecht 1996/3, p. 51-56.

17 Toebes, Migrantenrecht 1996/3, p. 197-199.

${ }^{18}$ Zie onder meer Kamerstukken II 1995/96, 24 233, nr. 4, p. 22-23.
} 
uitkering van het fonds kon worden besloten, te weten de volgende (zogenoemde zorginhoudelijke) voorwaarden:

1. Zorg verleend in of ter voorkoming van situaties van levensbedreiging, dan wel in of ter voorkoming van situaties van blijvend verlies van essentiële functies.

2. Zorg verleend in situaties waarin zich een gevaar voor derden voordoet. Dit geldt bijvoorbeeld voor bepaalde infectieziekten (in het bijzonder tbc) en bij psychische stoornissen die gepaard gaan met agressief gedrag. Ook zwangerschapszorg valt onder dit criterium. Daarnaast hebben kinderen van illegalen tevens toegang tot de preventieve jeugdgezondheidszorg alsmede tot een vaccinatieprogramma overeenkomstig het rijksvaccinatieprogramma.

Hierbij werd opgemerkt dat de toegang tot de zorg inclusief de huisartsenzorg voor alle illegalen openstaat. ${ }^{19}$ In deze voorwaarden zien we het advies van de NRV weerspiegeld.

5.2.4 Wijziging 'acute noodsituaties' in 'medisch noodzakelijke zorg'.

De kritiek op het begrip 'acute noodsituaties' bleef niet ongehoord. Tijdens de parlementaire behandeling van de Koppelingswet stelde Kamerlid Rouvoet bij amendement voor om het begrip 'acute noodsituaties' te vervangen door 'de verlening van noodzakelijke medische zorg'. ${ }^{20}$ Volgens Rouvoet was het begrip 'acute noodsituaties' in de praktijk moeilijk hanteerbaar. Het risico bestond dat illegalen in de praktijk zorg zou worden onthouden, waar later zou blijken dat wel degelijk van een noodsituatie sprake was. Ook zou het kunnen voorkomen dat zorg zou worden verleend waarvan de kosten niet op het fonds zouden kunnen worden verhaald. De term 'noodzakelijke medische zorg' zou volgens Rouvoet meer ruimte laten voor de professionele afweging van hulpverleners, zonder hen te dwingen iets te regelen. Hantering van het begrip 'noodzakelijke zorg' zou het ook mogelijk maken zorg te verlenen die nodig is, juist om te voorkomen dat iemand in een acute noodsituatie terecht komt, bijvoorbeeld bij chronisch zieken. ${ }^{21}$

Het kabinet kon zich vinden in dit amendement, met dien verstande dat niet werd gekozen voor de formulering 'de verlening van noodzakelijke medische zorg' maar voor 'de verlening van medisch noodzakelijke zorg'. Volgens minister Borst-Eilers was dan duidelijk dat het de arts is die de noodzaak van de zorg vaststelt. ${ }^{22}$ Over de term 'noodzakelijke medische zorg' zouden volgens haar immers weer eindeloze discussies kunnen ontstaan. ${ }^{23}$

Met de terminologie 'medisch noodzakelijke zorg' werd de eigen professionele verantwoordelijkheid van de zorgverlener bij de beoordeling van de medische klacht van de illegale vreemdeling centraal gesteld. De overheid wilde duidelijk op afstand blijven en achtte het praktisch ondoenlijk om voor te schrijven wat de grens is tussen acute problematiek en problematiek die dat niet zou zijn. De interpretatie van het begrip behoorde tot de

\footnotetext{
${ }^{19}$ Kamerstukken II 1995/96, 24 233, nr. 6, p. 62.

${ }^{20}$ Amendement van het lid Rouvoet, 11 oktober 1996, Kamerstukken II 1996/97, 24 233, nr. 18.

${ }^{21}$ Kamerstukken II 23 oktober 1996, 16-1134.

${ }^{22}$ Gewijzigd amendement van het lid Rouvoet ter vervanging van dat gedrukt onder nr. 18, 31 oktober 1996, Kamerstukken II 1996/97, nr. 43.

${ }^{23}$ Anderen zouden dan blijkbaar uitmaken wat noodzakelijk is, aldus minister van VWS Borst-Eilers, Kamerstukken II 31 oktober 1996, 20-1461.
} 
verantwoordelijkheid van de meest deskundige partij. De kwaliteit van de opleiding en de eisen die aan de beroepsuitoefening worden gesteld zouden voldoende borg staan voor een redelijk eenduidige en gelijke beoordeling op dit punt. $^{24}$

\subsection{Interpretatie van 'medisch noodzakelijke zorg' na inwerkingtreding Koppelingswet}

\subsubsection{Inleiding}

Met de hierboven besproken wijziging werd de discussie over de vraag wat onder medisch noodzakelijke zorg dient te worden verstaan niet afgesloten. Integendeel, het begrip bleef talloze malen onderwerp van discussie, zowel in de Tweede Kamer als in de praktijk. De uitleg van dit begrip varieerde van een enge tot een ruime interpretatie. ${ }^{25}$

5.3.2 Interpretatie van 'medisch noodzakelijke zorg' door het Koppelingsfonds en toenmalig Minister van VWS

Het Koppelingsfonds stelde zich op het standpunt dat 'bij alle vormen van zorg zich situaties kunnen voordoen die als medisch noodzakelijk kunnen worden aangeduid en dat de beoordeling daarvan niet ergens anders dan bij de behandelend medicus kan liggen'. Het Fonds omschreef grofweg wat onder medisch noodzakelijk, en dus van de mogelijkheid tot uitkering uit het Fonds, werd verstaan. Dit waren de volgende omstandigheden:

- Zorg verleend in geval of ter voorkoming van levensbedreiging.

- Zorg verleend in geval of ter voorkoming van blijvend verlies van essentiële functies.

- Zorg verleend in situaties waarbij zich gevaar voor derden voordoet, zoals bij besmetting met tbc maar ook bij psychische stoornissen die gepaard gaan met agressief gedrag. ${ }^{26}$

- Zorg bij zwangerschap en rond de geboorte.

Ivf en geslachtsveranderende behandelingen en bepaalde onderdelen op het gebied van tandheelkundige hulp vielen niet onder het begrip 'medisch noodzakelijke zorg'. Mede naar aanleiding van knelpunten in de praktijk, werd de minister van VWS herhaaldelijk om nadere opheldering van het begrip 'medisch noodzakelijke zorg' gevraagd. ${ }^{27}$ Toenmalig minister Borst-Eilers $^{28}$ verwees bij de uitleg consequent naar de (zorginhoudelijke) voorwaarden voor vergoeding van de Stichting Koppeling, die 'medisch noodzakelijk' geruime tijd interpreteerde als verstrekkingen zoals omschreven voor de (toenmalige) Zfw (exclusief enkele voorzieningen) en zoals die onder de dekking vallen van de AWBZ.

\subsubsection{Verwarring over 'medisch noodzakelijke zorg'}

\footnotetext{
${ }^{24}$ Kamerstukken II 16 oktober 1996, 13 853, Kamerstukken I 1996/97, 24 233, nr. 76c, p. 16.

${ }^{25}$ Uit het feit bijvoorbeeld dat het Koppelingsfonds bij het beoordelen van aanvragen vrijwel alle zorg die ook in het kader van de Zfw en de AWBZ was verzekerd als medisch noodzakelijke zorg beschouwt, kon volgens minister Borst-Eilers worden afgeleid dat er ruimte was voor een zeer ruime interpretatie van het begrip, Kamerstukken II 1999-2000, 19 637, nr. 505, p. 2-3.

${ }^{26}$ Kamerstukken II 1999-2000, 19 637, nr. 518, p. 2.

${ }^{27}$ Zie bijvoorbeeld Handelingen II 2000/01(Vragen van het lid Halsema), nr. 191, naar aanleiding van "Gestoorde illegaal aan lot overgelaten", de Volkskrant 3 oktober 2000.

${ }^{28}$ Minister van VWS tijdens kabinetten Kok I en Kok II, van augustus 1994-juli 2002.
} 
Een jaar na de inwerkingtreding van de Koppelingswet gaf het ministerie van VWS opdracht aan TNO-Preventie en Gezondheid (TNO-PG) om vervolgonderzoek te verrichten naar de toegankelijkheid van de Nederlandse gezondheidszorg voor illegalen. ${ }^{29}$ Eén van de bevindingen was dat een aantal zorgverleners in de veronderstelling verkeerde dat zij geen zorg meer mochten verlenen aan illegale patiënten uitgezonderd in bijzondere situaties. Er bleek veel verwarring te bestaan over de term medisch noodzakelijke zorg, waarschijnlijk door de verschuiving van acute medische zorg naar medisch noodzakelijke zorg. ${ }^{30}$ Deze constatering gaf aanleiding tot een motie van de Kamerleden Kamp en Verhagen, waarin werd voorgesteld om het begrip 'medisch noodzakelijke zorg' (weer) te interpreteren als 'zorg in urgente gevallen en in acute noodsituaties'. ${ }^{31}$ Met de motie werd beoogd duidelijk te maken dat de overheid wel degelijk criteria zou moeten ontwikkelen als het gaat om de vraag welke zorg voor financiering in aanmerking moet komen en welke niet. De motie werd verworpen. ${ }^{32}$

Volgens de minister was sprake van een helder beginsel, maar was het niet eenvoudig een voor iedereen acceptabele omschrijving van medische zorg, die niet kan worden uitgesteld of onthouden, te geven. ${ }^{33}$

\subsubsection{Commissie Smeets: onzekere verblijfsstatus speelt een rol}

In 2001 werd de Commissie Smeets ingesteld om na te gaan wat de invloed is van medische aspecten op de toestroom van vreemdelingen tot Nederland. In dit kader boog de commissie zich tevens over de vraag welke vreemdelingen recht hebben op medische zorg. Voor de beantwoording van de vraag of een vreemdeling minder recht heeft op zorg dan een Nederlandse staatsburger, ging de Commissie Smeets na wat wordt verstaan onder medisch noodzakelijke zorg. De commissie stelde voorop dat het begrip 'medisch noodzakelijke zorg' zich moeilijk in eenduidige criteria laat vatten die zowel voor de medicus als de jurist hanteerbaar zijn.

Volgens de commissie bevat het begrip 'noodzakelijk' een waardeoordeel over de kans dat het onthouden van de zorg voor het betreffende individu tot negatieve uitkomsten leidt. Het waardeoordeel over het begrip 'noodzakelijk' is gebaseerd op de wisselwerking van de drie elementen 'kans', 'individu' en 'uitkomst', waarbij 'uitkomst' nader kan worden geoperationaliseerd naar sterfte (mortaliteit), ziektelast (morbiditeit), handicaps- en beperkingen (disabilities) en kwaliteit van leven. Hierbij merkte de commissie op dat volgens sommigen een dergelijk waardeoordeel op morele en haalbaarheidsgronden niet kan worden gegeven. Anderen deden wel pogingen om de elementen 'kans', 'individu' en 'uitkomst' nader te expliciteren en te komen tot grenzen rond het begrip 'medisch noodzakelijk zorg'. Dit laatste was met name aan de orde bij de samenstelling van het basispakket (van het toenmalige Ziekenfonds, VD), waarbij het waardeoordeel zich afspeelt in de context van de rechtvaardiging van het aanwenden van beperkte gemeenschapsmiddelen ten behoeve van de zorgvraag van een

\footnotetext{
${ }^{29}$ Vooronderzoek werd verricht door de Landelijke Vereniging voor GGD 'en TNO-PG.

${ }^{30}$ In een aantal gevallen had dit adequate zorgverlening aan illegale patiënten belemmerd, Reijneveld \& Van Herten 2000, p. 92.

${ }^{31}$ Kamerstukken II 1999-2000, 19 637, nr. 512 (motie Kamp en Verhagen).

${ }^{32}$ Kamerstukken II 22 maart 2000, 59-4117.

${ }^{33}$ Brief van de Minister van VWS aan de Voorzitter van de Tweede Kamer, 21 maart 2000, Kamerstukken II 1999 2000, 19637, nr. 518.
} 
individu. De commissie was van mening dat er vanuit de medische ethiek geen grondslag was voor het maken van onderscheid tussen vreemdelingen en Nederlandse staatsburgers (element 'individu'); de waardering van de uitkomsten en kansen op basis van medische inzichten zal niet veranderen en de medisch ethische beroepsnormen stellen daarnaast dat een ieder die zorg nodig heeft ook geholpen dient te worden. ${ }^{34}$

De commissie adviseerde de Ministers ${ }^{35}$ om het begrip 'medisch noodzakelijke zorg' zo uit te leggen dat daaronder wordt verstaan de zorg volgens het basispakket van het Ziekenfonds. Aan een ieder die op Nederlands grondgebied verblijft, dient de overheid het recht op noodzakelijke zorg te blijven garanderen, waarbij de medische professie het primaat houdt op indicatiestelling, aldus de commissie. ${ }^{36}$ Wel kan een onzekere verblijfsstatus onderdeel vormen van de gebruikelijke indicatiestelling door de arts, bijvoorbeeld als door de te verwachten verblijfsduur het beoogde behandeleffect niet kan worden bereikt. Hier is het criterium echter niet dat de medische zorg niet noodzakelijk zou zijn, maar dat de effecten van de zorg gezien de beperkte tijdsduur van de behandeling als gevolg van de onzekere verblijfsstatus van de hulpvrager niet kunnen worden behaald. Op grond daarvan kan de arts besluiten de behandeling niet te beginnen of voor een andere behandeling te kiezen. ${ }^{37}$ De conclusie van de commissie dat medisch noodzakelijke zorg bij het samenstellen van het basispakket werd ingeperkt tot strikt noodzakelijke zorg, werd niet door het kabinet gedeeld. ${ }^{38}$

\subsubsection{Versmalling naar 'acute medische zorg'}

In de jaren hierna verwees toenmalig minister van VWS Hoogervorst in antwoorden op Kamervragen naar de oorspronkelijke formulering in de toelichting van het wetsvoorstel van de Koppelingswet, te weten 'een situatie waarin de verlening van medische zorg niet kan worden onthouden of uitgesteld zonder het leven of de gezondheidstoestand van betrokkene dan wel de Nederlandse volksgezondheid ernstig in gevaar te brengen' ${ }^{39}$ Volgens de minister diende de arts te beoordelen of de zorg noodzakelijk en niet-uitstelbaar is. Kortom: de uitleg van 'medisch noodzakelijke zorg' werd weer versmald tot 'acute medische zorg'. ${ }^{40}$ Daarnaast adviseerde hij de Stichting Koppeling om rekeningen afkomstig van AWBZ gefinancierde zorg

\footnotetext{
${ }^{34}$ Commissie Smeets 2004, p. 54-55.

${ }^{35}$ Toenmalig Minister voor Vreemdelingenzaken en Integratie respectievelijk Minister van VWS.

${ }^{36}$ Commissie Smeets 2004, p. 54.

${ }^{37}$ Commissie Smeets 2004, p. 54-55.

${ }^{38}$ Brief van de Minister voor Vreemdelingenzaken en Integratie van 19 maart 2004 (Kamerstukken II 2003/04, 19637 nr. 806), p. 12.

${ }^{39}$ Handelingen II 2004/05 (Vragen van het lid De Vries), nr. 1454, naar aanleiding van VPRO "De Ochtenden", 18 januari 2005, Handelingen II 2005/06 (Vragen van het lid Arib), nr. 804, naar aanleiding van 'Ziekenhuizen moeten hard zijn', NRC Handelsblad, 14 januari 2006, Handelingen II 2005/06 (Vragen van het lid Vendrik), nr. 871, naar aanleiding van 'Ziekenhuizen moet hard zijn', NRC Handelsblad, 14 januari 2006, Handelingen II 2005/06 (Vragen van het lid Arib), nr. 1690, naar aanleiding van de gedragscode van de Nederlandse Vereniging van Kinderartsen voor medische zorg aan illegale kinderen en kinderen van asielzoekers, Handelingen II 2006/07 (Vragen van het lid Arib), nr. 33, naar aanleiding van berichten over het weigeren van illegale onverzekerde patiënten ('De straatdokter is boos', de Volkskrant 15 juli 2006, De Visser, de Volkskrant 17 juli 2006 en 'Hulp aan illegalen', de Volkskrant 18 juli 2006.

${ }^{40}$ Zie ook Van Wijlick, MC 2006/39, p. 1535. Hij wees op de mogelijk schadelijke effecten van deze smalle uitleg op de langere termijn voor de patiënt in kwestie en de volksgezondheid in het algemeen, bijvoorbeeld bij een uitbraak van SARS of vogelgriep.
} 
niet meer in behandeling te nemen. ${ }^{41}$ Onverzekerde vreemdelingen zonder wettig verblijf zouden niet in aanmerking komen voor langdurige zorg die een onbeperkt verblijf in Nederland veronderstelde. Het Koppelingsfonds zou alleen bedoeld zijn voor financiële compensatie voor het verlenen van medisch noodzakelijke zorg die geen uitstel toelaat. ${ }^{42}$ De in mijn voorwoord vermelde casus van het gehandicapte kind dat anderhalf jaar in het AMC verbleef, was een direct gevolg van dit beleid.

Door deze beperkte uitleg ontstond bij hulpverleners de overtuiging dat de zorgplicht voor illegalen alleen bij zaken van leven en dood zou bestaan. ${ }^{43}$ Kok en Sikken (straatdokters voor illegalen) signaleerden dat ziekenhuizen onverzekerden en patiënten zonder identiteitsdocumenten - onder wie illegalen - bij de balie wegstuurden zonder dat een arts de ernst van hun aandoening had vastgesteld. ${ }^{44}$ Daarnaast voerden ziekenhuisdirecties de druk op artsen op om geen zorg te verlenen als er (mogelijk) sprake was van onverzekerdheid. ${ }^{45}$

De IGZ deed de aanbeveling om het begrip 'medisch noodzakelijke zorg' te verhelderen om conflicten tussen zorginstellingen en verwijzers te voorkomen. ${ }^{46}$ De IGZ erkende dat het begrip medisch noodzakelijke zorg een lastig hanteerbaar begrip is. De interpretatie loopt uiteen van zorg bij een levensbedreigende situatie tot zorg die de kwaliteit van het leven beïnvloedt, met vele gradaties daartussen. De notitie wekte de indruk dat de IGZ onder medisch noodzakelijke zorg alleen 'acute medische zorg' verstond. ${ }^{47}$ In zijn antwoord op Kamervragen over dit rapport, gaf de minister aan dat noodzakelijke zorg beperkter is dan het basispakket minus enkele uitzonderingen. Er zou geen sprake zijn van een foute definitie door de IGZ, omdat de arts bepaalt wanneer iets medisch noodzakelijk is.

Deze opvatting werd door de minister genuanceerd in antwoord op de vraag van de kamer om aan te geven welke zorg voor financiering in aanmerking kwam (mede naar aanleiding van de zaak Bavo-RNO groep/Staat). ${ }^{48}$ Dat waren nagenoeg alle zorgvormen die opgenomen waren in het Nederlandse sociale ziekteverzekeringspakket, maar slechts onder de voorwaarde dat de arts de vraag of het hier om medisch noodzakelijke zorg ging, positief beantwoordt, aldus de minister. ${ }^{49}$ Hierbij verwees hij naar de voorwaarden die de Stichting Koppeling voor compensatie hanteerde. De uitkomst van de beoordeling of in een specifiek geval sprake is van medisch noodzakelijk zorg, kan anders uitwerken voor iemand die niet rechtmatig in Nederland verblijft dan voor iemand die rechtmatig in Nederland woont. Van iemand die niet rechtmatig in Nederland verblijft mag niet per definitie worden uitgegaan dat hij hier gedurende onbeperkte tijd zal blijven. De noodzaak van de medische zorg diende dan ook volgens de minister te worden bezien in samenhang met de duur van het verblijf.

\footnotetext{
${ }^{41}$ Zie par. 4.3.2.2.

${ }^{42}$ Handelingen II 2004/05, 357 (antwoord op Kamervragen van Arib).

${ }^{43}$ Zie ook Den Otter en Tavenier, MC 2006/34, p. 1316-1318 en 'De straatdokter is boos', de Volkskrant 15 juli 2006.

${ }^{44}$ Kok en Sikken 2006, p. 843.

${ }^{45}$ Van den Muijsenbergh, Lagro-Janssen \& Assmann, MC 27 juni 2006.

${ }^{46}$ Interne nota IGZ, 27 juni 2006, IGZ-AL-08-25123.

47 Brief van de Minister van VWS van 25 september 2006, CZ-K-U-2702502.

${ }^{48}$ Zie par. 4.3.2.2.

${ }^{49}$ Brief van de Minister van VWS van 16 oktober 2006, Z/VV-2723002. Opvallend is dat de minister schreef dat 'illegalen door de Koppelingswet geen recht op zorg hebben ingevolge de sociale ziektekostenverzekeringen'. Hij bedoelde kennelijk 'geen recht op financiering'.
} 
Voorkómen moest worden dat er door een ruime interpretatie van regelgeving in Nederland een aanzuigende werking uitgaat naar personen elders in de wereld om illegaal naar Nederland te komen met het oogmerk om een medische behandeling te ondergaan. ${ }^{50}$

\subsection{Invulling van het begrip 'medisch noodzakelijke zorg' door beroepsgroepen}

De overheid liet de invulling van 'medisch noodzakelijk' over aan de professionals in de hoop dat deze tot nadere uitwerking zou komen. Dit kwam moeizaam van de grond.

De Nederlandse Vereniging voor Kindergeneeskunde (NVK) nam als eerste beroepsgroep het initiatief om tot een gedragscode te komen waarin richtlijnen en standpunten worden gegeven hoe Nederlandse kinderartsen dienen om te gaan met zieke kinderen zonder geldige verblijfspapieren. ${ }^{51}$ Deze gedragscode geeft geen nadere invulling van het begrip 'medisch noodzakelijke zorg', maar stelt dat de kinderarts ongeacht de verblijfs- of verzekeringsstatus of financiële middelen van het kind en zijn ouders te allen tijde de medische zorg en begeleiding verleent die hij nodig acht en die hij in vergelijkbare gevallen zou verlenen aan Nederlandse kinderen. ${ }^{52}$ De multidisciplinaire richtlijn 'Medisch en psychosociaal nieuwkomersonderzoek vluchtelingenkinderen' heeft als uitgangspunt het recht van vluchtelingenkinderen op dezelfde gezondheidszorg als Nederlandse kinderen. Het doel van de richtlijn is dat extra gezondheidsrisico's van vluchtelingenkinderen in een vroeg stadium worden opgespoord en behandeld. ${ }^{53}$

Ook GGZ Nederland (nu: de Nederlandse ggz) gaat in de handreiking 'Onverzekerden in de GGZ' in op het begrip 'medisch noodzakelijke zorg'. ${ }^{54}$ Daarbij gaat GGZ Nederland uit van de richtlijn van de commissie Klazinga (zie hierna). Alle personen die in Nederland verblijven hebben recht op 'medisch noodzakelijke zorg' met inbegrip van zorg die moet worden verleend om te voorkomen dat iemand in een acute noodsituatie terechtkomt. Zorg, die onder de basisverzekering valt, is altijd 'verantwoord en passend' en kan dus worden aangemerkt als medisch noodzakelijke zorg. Het is uiteindelijk aan de arts/psychiater om te beoordelen of zorg noodzakelijk en niet-uitstelbaar is, handelend vanuit zijn medisch-professionele verantwoordelijkheid en zonder onderscheid des persoons. ${ }^{55}$ Ook de huisartsen gaan uit van het advies van de commissie Klazinga. ${ }^{56}$

\subsection{Medisch-ethische overwegingen met betrekking tot het begrip medisch noodzakelijke zorg}

Vanuit de medische ethiek is eveneens nagedacht over de vraag op welke zorg ongedocumenteerden aanspraak kunnen maken.

\footnotetext{
${ }^{50}$ Zie ook het standpunt van de Minister dat het Koppelingsfonds alleen bedoeld zou zijn voor financiële compensatie voor het verlenen van medisch noodzakelijke zorg die geen uitstel toelaat, Handelingen II 2004/05, nr. 357 (antwoord op Kamervragen van Arib).

${ }^{51}$ NVK 2006, nvk.pedianet.nl.

${ }^{52}$ Of dat in de praktijk ook gebeurt, komt in hoofdstuk 9 aan de orde.

${ }^{53}$ De richtlijn ligt ter autorisatie bij de betrokken organisaties en verengingen, expertisegroepglobalchildhealth.nl (laatst geraadpleegd 14 oktober 2020).

${ }^{54}$ Handreiking Onverzekerden in de GGZ, 2006, herzien augustus 2011, versie110816, ggznederland.nl.

${ }^{55}$ Handreiking Onverzekerden in de zorg 2011, versie110816, p. 12.

${ }^{56}$ Adviezen voor huisartsen (rapport Arts en Vreemdeling), lhv.nl (laatst geraadpleegd 16 juni 2020).
} 
Medische ethiek kan zorgverleners inzicht geven in relevante waarden en de toepassing ervan in concrete situaties. ${ }^{57}$ De klassieke indeling van de grondbeginselen van de medische ethiek is samengevat in de volgende vier uitgangspunten: 1. niet schaden van de persoon, 2 . weldoen aan de persoon, 3. bevorderen van persoonlijke autonomie en 4. (sociale) rechtvaardigheid. $^{58}$

Van de Vathorst ziet vanuit de medische beroepsethiek geen enkele grond om illegaal in Nederland verblijvende mensen of patiënten anders te behandelen dan legaal verblijvende mensen. Dit leidt zij af uit de centrale waarden in de medische ethiek: respect voor de autonomie, weldoen, niet schaden en rechtvaardigheid. Onder rechtvaardigheid valt dat er geen onderscheid mag worden gemaakt op andere gronden dan de behoefte van de patiënt aan medische zorg. ${ }^{59}$ De Koppelingswet zou echter uitnodigen om een onderscheid naar verblijfsof verzekeringsstatus te maken. ${ }^{60}$

De eerder genoemde Commissie Smeets kwam zoals hierboven gezegd tot dezelfde conclusie. $^{61}$

De KNMG wijst er in haar ethische toolkit op dat vanuit het principe van rechtvaardigheid gelijke gevallen gelijk behandeld dienen te worden, en ongelijke gevallen ongelijk. ${ }^{62}$ Sociale status, nationaliteit en juridische status mogen (onder andere) geen rol spelen bij het principe dat ieder mens gelijkwaardig is. ${ }^{63}$

\subsection{Commissie Klazinga}

Naar aanleiding van signalen van artsen inhoudende dat de medische zorg aan onverzekerde vreemdelingen onder grote druk stond, namen LHV en GGZ Nederland, ondersteund door de IGZ, het initiatief om een commissie in te stellen om te adviseren over de medische zorg aan ongedocumenteerde vreemdelingen. ${ }^{64}$ Deze signalen bestonden vooral uit situaties waarbij de medische zorg voor illegalen onder druk stond door het spanningsveld tussen de zorgplicht en de dreiging van financieel verlies of tekorten. ${ }^{65}$ Doel van de commissie was om richtlijnen te formuleren voor het professioneel handelen van artsen en andere betrokkenen bij dergelijke dilemma's.

De commissie Klazinga was van oordeel dat de voor de beroepsgroep geldende normen niet toestaan om onverzekerde vreemdelingen anders te behandelen dan verzekerde vreemdelingen. Onder medisch noodzakelijke zorg verstond de commissie die zorg, waarvoor een persoon om hulp vraagt aan een arts en waarvan de arts bepaalt dat hij die moet leveren om die persoon in goede gezondheid te houden, (medisch) lijden te verminderen of het risico op

\footnotetext{
${ }^{57}$ Legemaate en Widdershoven 2016, p. 16.

${ }^{58}$ Beauchamp \& Childress, 1979/2001.

${ }^{59}$ Van de Vathorst, 1999, p. 20.

${ }^{60}$ Van de Vathorst 1999, p. 21.

${ }^{61}$ Commissie Smeets 2005, p. 54, zie par. 5.3.4.

${ }^{62}$ Knmg.nl (laatst geraadpleegd 4 augustus 2020).

${ }^{63}$ KNMG, Draaiboek 'Triage op basis van niet-medische overwegingen voor IC-opname ten tijde van fase 3 in de COVID-19 pandemie', 16 juni 2020, p. 11.

${ }^{64}$ De commissie adviseerde tevens over medische zorg voor uit te zetten asielzoekers en vreemdelingen.

${ }^{65}$ Commissie Klazinga 2007, p. 39.
} 
complicaties te verminderen. ${ }^{66}$

De commissie gaf de volgende adviezen en richtlijnen over het begrip 'medisch noodzakelijke zorg' voor illegale, onverzekerde vreemdelingen ${ }^{67}$ :

1. 'Medisch noodzakelijke zorg' dient naar het oordeel van de commissie als 'verantwoorde en passende medische zorg' te worden gedefinieerd. Deze zorg is doeltreffend en doelmatig, wordt patiëntgericht verleend en is afgestemd op de reële behoefte van de patiënt. Daarbij baseert een arts de indicatie op een gedegen analyse van de gezondheidsproblemen, indiceert conform de normen van de beroepsgroep en kosteneffectief. Bij gelijke effectiviteit van interventies geven veiligheids- en doelmatigheidsargumenten de doorslag.

2. Artsen kunnen de verblijfsduur van illegale vreemdelingen in Nederland vaak niet voorspellen. Zij kunnen bij zorg, die uitgesteld kan worden in combinatie met de verwachting van kort verblijf in Nederland, de behandeling beperkt houden of afzien van behandeling. Als echter de duur van het verblijf in Nederland onduidelijk of langdurig is, is de continuïteit van adequate medische zorg belangrijker en dient de medische zorg gelijk te zijn aan de reguliere basiszorg voor verzekerden.

3. Artsen bieden passende en verantwoorde zorg door dezelfde richtlijnen, protocollen, standaarden en gedragsregels van de medische en wetenschappelijke beroepsorganisaties te gebruiken als bij reguliere zorg.'

Het advies van de Commissie Klazinga staat aan de basis van artikel 122a Zvw. In de debatten over deze regeling verwijst de minister van VWS naar het advies. Het advies heeft inmiddels de status van richtlijn gekregen. ${ }^{68}$

\subsection{Verhouding medisch noodzakelijke zorg met basispakket $\mathrm{Zvw}$}

Zoals vermeld in paragraaf 4.4.1.1, koppelt de bijdrageregeling de aanspraak van de zorgverlener op vergoeding van zorgkosten aan de omvang van het basispakket van de Zvw. De vraag of een bepaalde zorgvorm in het basispakket dient te worden opgenomen, wordt beantwoord aan de hand van vier pakketprincipes: ${ }^{69}$

- Werkt de zorgvorm bij de betreffende aandoening? (Effectiviteit);

- Staan de kosten van de zorgvorm in een redelijke verhouding tot de baten? (Kosteneffectiviteit);

- Is de aandoening dermate ernstig en zijn de kosten van de zorgvorm dermate hoog dat vergoeding vanuit het basispakket gerechtvaardigd is? (Noodzakelijkheid);

\footnotetext{
${ }^{66} \mathrm{Bij}$ de interpretatie van het begrip sloot de commissie aan bij de KNMG-standpunten (KNMG 1998 en KNMG 2000b) en de Kwaliteitswet Zorginstellingen (oud).

${ }^{67}$ Commissie Klazinga 2007, p. 9. Overige adviezen van de commissie over zorg verleend aan illegalen komen elders ter sprake.

${ }^{68}$ Derckx \& Bloemen, MC 2020/9, p. 18-21.

${ }^{69}$ Zorginstituut Nederland, Van goede zorg verzekerd. Hoe Zorginstituut Nederland adviseert over de inhoud van het basispakket, mei 2015, te raadplegen via zorginstituutnederland.nl. Deze criteria zijn niet overigens wettelijk vastgelegd maar worden in de MvT van de Zvw genoemd als uitgangspunten voor het basispakket. Het Zorginstituut adviseert de minister over opname van zorgvormen in het basispakket.
} 
- Kan de samenleving de totale kosten van opname van de zorgvorm in het basispakket dragen? (Uitvoerbaarheid).

Uit het bovenstaande kan worden geconcludeerd dat zorg die onder het basispakket valt niet per definitie medisch noodzakelijke zorg betreft. De zorgvorm kan immers op grond van andere overwegingen dan noodzakelijkheid in het basispakket zijn opgenomen. Andersom valt niet iedere vorm van medisch noodzakelijke zorg onder het basispakket. Op grond van de overwegingen (kosten)effectiviteit, noodzakelijkheid en uitvoerbaarheid kan de zorgvorm uitgesloten zijn van het basispakket. In beide gevallen valt de zorg niet onder de bijdrageregeling. ${ }^{70}$ De zorgverlener die deze medisch noodzakelijke zorg wel verstrekt, doet dit met het risico dat deze niet wordt betaald. Daarmee wordt de verantwoordelijkheid van de staat afgewenteld op de hulpverlener.

\subsection{Langdurige zorg}

Het verstrekken van langdurige zorg aan een onrechtmatig verblijvende vreemdeling staat het meest op gespannen voet met diens vertrekplicht. Het langdurig onder de hoede nemen van de vreemdeling, bijvoorbeeld ingeval van dementie, lijkt niet te stroken met diens status. De vraag is wanneer zorg langdurig is. Op grond van de Wlz is sprake van een recht op zorg als sprake is van een blijvende behoefte aan bepaalde intensieve zorg. ${ }^{71}$ 'Blijvend' doelt op 'van niet voorbijgaande aard'. ${ }^{72}$ Er dient sprake te zijn van ernstig nadeel van de persoon. Hiervan is bijvoorbeeld sprake als iemand zichzelf niet meer kan redden in de maatschappij, zichzelf ernstig verwaarloost of als de veiligheid van iemand anders ernstig wordt bedreigd. De minister van Medische Zorg en Sport heeft expliciet benadrukt dat het ook bij langdurige zorg aan de arts is om te bepalen of sprake is van medisch noodzakelijke zorg. ${ }^{73}$ Gelet op het advies van de commissie Klazinga ('Als echter de duur van het verblijf in Nederland onduidelijk of langdurig is, is de continuïteit van adequate medische zorg belangrijker en dient de medische zorg gelijk te zijn aan de reguliere basiszorg voor verzekerden'), dient indien noodzakelijk ook langdurige zorg aan ongedocumenteerden te worden vergoed volgens de bijdrageregeling. Dit geldt ook voor de openingscasus uit hoofdstuk één van de ongedocumenteerde vrouw die in een hospice wil sterven.

\subsection{Tussenconclusie}

Het begrip 'medisch noodzakelijke zorg' is multi-interpretabel gebleken. Het is inmiddels evident dat medisch noodzakelijke zorg meer behelst dan louter zorg in levensbedreigende situaties. Het meest controversieel was de vraag of langdurige zorg hier ook onder valt, gelet op de onzekere verblijfsstatus van de onrechtmatig verblijvende vreemdeling. Het voorlopige sluitstuk van deze discussie vormt de richtlijn van de commissie Klazinga, waarin onomwonden staat dat medisch noodzakelijke zorg verantwoorde en passende medische zorg is. Nu dit advies

\footnotetext{
${ }^{70}$ Zie verder par. 9.6.1.

${ }^{71}$ Art. 3.2.1 lid $1 \mathrm{Wlz}$.

${ }^{72}$ Art. 3.2.1 lid 2 sub a Wlz.

${ }^{73}$ Brief van de Minister voor Medische Zorg en Sport aan de Voorzitter van de Tweede Kamer, 30 maart 2018, 1322178-174975-Z, p. 4.
} 
de status van richtlijn heeft gekregen, kan worden geconcludeerd dat onrechtmatig verblijvende vreemdelingen passende en verantwoorde zorg dienen te ontvangen conform reguliere zorg. Dit geldt ook bij twijfel over de te verwachten verblijfsduur en voor langdurige zorg. Ook vanuit de medische ethiek is er geen grond om de onverzekerde vreemdeling een andere behandeling te geven dan een Nederlandse staatsburger. In zoverre bieden de medische ethiek en de medisch professionele standaard een waarborg voor de toegang tot gezondheidszorg van onrechtmatig verblijvende vreemdelingen. De openingscasus van dit hoofdstuk illustreert dat ongedocumenteerden in de praktijk echter niet altijd passende en verantwoorde zorg conform reguliere zorg ontvangen.

\subsection{Hulpverleningsplicht artsen en tandartsen}

\subsubsection{Inleiding}

Bezagen we de hulpverleningsplicht van zorgverleners tot dusverre vanuit een breed perspectief, in deze paragraaf staat de hulpverleningsplicht in enge zin centraal. Bezien wordt in hoeverre artsen gehouden zijn om medisch noodzakelijke zorg aan onrechtmatig verblijvende vreemdelingen te bieden. De hulpverleningsplicht kent twee dimensies: de plicht om in bepaalde omstandigheden medische hulp te verlenen en de plicht om een geneeskundige behandelingsovereenkomst aan te gaan. ${ }^{74}$ Normatieve richting voor de hulpverleningsplicht zijn diverse internationale en nationale gedragsregels, een aantal bepalingen uit het $\mathrm{Sr}$ en de tweede tuchtnorm van de Wet op de beroepen in de individuele gezondheidszorg (Wet BIG, artikel 47).

\subsubsection{Medisch-professionele standaard arts}

De hulpverleningsplicht dient te worden bezien in het licht van de professionele standaard van de arts (artikel 7:453 Wet op de geneeskundige behandelingsovereenkomst, Wgbo). Deze standaard bestaat uit twee typen normen die het handelen van de arts normatief bepalen: de medisch-professionele standaard aan de ene kant en de rechten van de patiënt en andere maatschappelijke normen aan de andere kant. De medisch-professionele standaard wordt in beginsel door de beroepsgroep zelf bepaald. ${ }^{75}$ De medisch-professionele standaard wordt omschreven als: 'zorgvuldig volgens de inzichten van de medische wetenschap en ervaring handelen als een redelijk bekwaam arts van gelijke medische categorie in gelijke omstandigheden met middelen die in redelijke verhouding staan tot het concrete behandelingsdoel' ${ }^{76}$ Deze norm is de algemene norm die civiel-, straf- of tuchtrechtelijk kan worden getoetst, evenals in het klachtrecht.

Richtlijnen worden beschouwd als uitdrukking van de medisch-professionele standaard. In beginsel is de beroepsbeoefenaar eraan gebonden. De arts mag en moet van een richtlijn afwijken als dit in het belang van een goede patiëntenzorg wenselijk is. ${ }^{77}$

De professionele autonomie van de arts beperkt zich tot de medisch-inhoudelijke kant,

\footnotetext{
${ }^{74}$ Brands 1997, p. 19.

${ }^{75}$ Leenen e.a. 2017 , p. 65.

${ }^{76}$ Leenen e.a. 2017 , p. 69-70.

${ }^{77}$ HR 2 maart 2011, TvGR 2001/16.
} 
de medisch-professionele autonomie genoemd. De arts mag geen inbreuk maken op de rechten van de patiënt en overige maatschappelijke normen, waaronder wettelijke regelingen. ${ }^{78}$ Kostenoverwegingen zijn geen reden om af te wijken van de medisch-professionele standaard. ${ }^{79}$

\subsubsection{Artseneed}

De eed die door artsen wordt afgelegd bij de uitreiking van het artsdiploma, weerspiegelt de unieke ethische de waarden van de beroepsgroep. ${ }^{80}$ Deze zien niet alleen op de persoonlijke toewijding en houding tot de patiënt ("ik stel het belang van de patiënt voorop en eerbiedig zijn opvattingen") maar ook op de verhouding van de arts tot de maatschappij ("ik zal de beschikbaarheid en toegankelijkheid van de gezondheidszorg bevorderen"). Onder de professionele normen waaraan een arts gehouden is, vallen ook diverse verklaringen en richtlijnen van internationale organisaties, zoals de 'International Code of Medical Ethics' en de 'Declaration of Geneva' van de World Medical Association en het handboek over mensenrechten van de British Medical Association. ${ }^{81}$

\subsubsection{Internationale gedragsregels}

De internationale gedragsregels voor artsen schrijven voor dat een arts noodhulp dient te verlenen als een humanitaire plicht, tenzij hij verzekerd is dat anderen bereid en in staat zijn om dergelijke zorg te geven. ${ }^{82}$ Uit de gedragsregels vloeit ook voort dat de arts hulp dient te verlenen in noodsituaties. Buiten noodsituaties bestaat een dergelijke plicht dus niet.

\subsubsection{Gedragsregels}

Gedragsregels geven concrete uitwerking van de morele waarden van de arts. Het zijn praktische en ethische normen die binnen de beroepsgroep als moreel bindend kunnen worden beschouwd. Ondanks het feit dat gedragsregels geen wettelijke status hebben, zijn zij juridisch relevant. Als onderdeel van de professionele standaard werken zij door in zowel het civiele recht als het tuchtrecht.

Voor de medische zorg aan onrechtmatig verblijvende vreemdelingen zijn de volgende KNMG-gedragsregels relevant:

\section{Algemeen}

I.1 De arts laat zich bij zijn beroepsuitoefening leiden door:

- de bevordering van de gezondheid en het welzijn van de mens;

- de kwaliteit van zorg;

\footnotetext{
${ }^{78}$ Leenen e.a. 2017 , p. 74.

${ }^{79}$ Leenen e.a. 2017 , p. 75.

${ }^{80} \mathrm{NFU}, \mathrm{KNMG}$ en VSNU, Nederlandse artseneed, 5e (herziene) druk, maart 2010.

${ }^{81}$ The British Medical Association: The medical profession \& human rights. Handbook for a changing agenda. London, New York: Zed Books Ltd, 2001.

${ }^{82}$ WMA International Code of Medical Ethics, Adopted by the $3^{\text {rd }}$ General Assembly of the World Medical Association, London, England, October 1949, and amended by the $22^{\text {nd }}$ World Medical Assembly, Sydney, Australia, August 1968 and the 35 ${ }^{\text {th }}$ World Medical Assembly, Venice, Italy, October 1983 and the 57 $7^{\text {th }}$ WMA General Assembly, Pilanesberg, South Africa, October 2006.
} 
- het respect voor zelfbeschikking van de patiënt;

- het doelmatige en rechtmatige gebruik van voor de zorg bestemde gelden en

middelen

- het belang van de volksgezondheid.

I. Aan ieder die zich tot hem wendt in zijn hoedanigheid als arts verleent hij de noodzakelijke behandeling, begeleiding, adviezen en beoordelingen overeenkomstig de eisen, die hem op grond van zijn beroep en deskundigheid mogen worden gesteld.

II.2 De arts zal patiënten in gelijke gevallen gelijk behandelen. Discriminatie wegens godsdienst, levensovertuiging, ras, geslacht of op welke grond dan ook, is niet toegestaan. De arts houdt rekening met de levensbeschouwelijke opvattingen en het cultuurpatroon van zijn patiënten, alsmede met eventuele taalbarrières.

II.3 De arts stemt de hulpverlening af op de reële individuele behoefte van de patiënt.

II.5 De arts is er verantwoordelijk voor dat continuïteit van de hulpverlening en een goede bereikbaarheid verzekerd zijn, onverlet de verantwoordelijkheid die hiervoor bij de instelling ligt waar hij werkzaam is.

II.6 De arts verleent in noodsituaties en bij calamiteiten te allen tijde en voor zover mogelijk eerste hulp.

Uit bovengenoemde gedragsregels kan worden afgeleid dat iedereen toegang tot noodzakelijke zorg dient te hebben en dat artsen geen onderscheid mogen maken op welke grond dan ook. Hieronder valt ook de verblijfsrechtelijke status.

\subsubsection{Strafrechtelijke hulpverleningsplicht}

Een zorgplichtige is strafbaar indien door zijn nalatigheid de ander in een hulpeloze toestand is geraakt, respectievelijk als hij nalaat om in levensgevaar verkerende personen te helpen. Het gaat hierbij om de artikelen 255 en $450 \mathrm{Sr}$.

Artikel $255 \mathrm{Sr}$ bepaalt dat wordt gestraft degene die opzettelijk iemand tot wiens onderhoud, verpleging of verzorging hij krachtens wet of overeenkomst verplicht is in een hulpeloze toestand brengt of laat, met een strafverzwaring als dit zwaar lichamelijk letsel of de dood tot gevolg heeft (artikel $257 \mathrm{Sr}$ ). Het gaat hier om een opzetdelict. Er zal ten minste voorwaardelijk opzet moeten worden bewezen. Daarnaast dient te worden bewezen dat de patiënt in hulpeloze toestand verkeerde. In het kader van de geneeskundige behandelingsovereenkomst zal dat lastig te bewijzen zijn.

Artikel $255 \mathrm{Sr}$ richt zich tot personen die een speciale (ver)zorg(ings)plicht hebben jegens de hulpbehoevende. Dat geldt niet voor artikel $450 \mathrm{Sr}$. Op grond van dit artikel is strafbaar degene die nalaat de nodige hulp te verlenen aan iemand die in levensgevaar verkeert. Ook voor dit delict dient (tenminste voorwaardelijk) opzet te worden bewezen. In de reguliere zorg komt het delict zelden daardoor voor. ${ }^{83}$ Toegespitst op het onderwerp van dit proefschrift, zal dit artikel alleen van toepassing zijn bij weigering van de hulpverlener om een ongedocumenteerd te behandelen die in een levensbedreigende situatie verkeert.

\footnotetext{
${ }^{83}$ Opzet werd in een aantal zaken in de alternatieve zorg bewezen geacht.
} 


\subsubsection{Tuchtrechtrechtelijke hulpverleningsplicht}

Artsen zijn op grond van de Wet BIG aan wettelijk tuchtrecht onderworpen. Doel van het tuchtrecht is het bewaken van de kwaliteit van het handelen van de individuele beroepsbeoefenaar. Artikel 47 lid 1 Wet BIG bevat twee tuchtnormen waaraan de tuchtrechter kan toetsen. De eerste tuchtnorm (artikel 47 lid 1 sub a Wet BIG) heeft betrekking op het handelen of nalaten van handelen in strijd met de zorg die de beroepsbeoefenaar behoort te betrachten ten opzichte van de patiënt of diens naaste betrekkingen. Het gaat bij deze norm om de eigen patiënt van de hulpverlener. De tweede tuchtnorm (artikel 47 lid 1 sub b Wet BIG) betreft gedragingen die niet door de eerste norm worden bestreken maar in strijd zijn met hetgeen een behoorlijk beroepsbeoefenaar betaamt. Hieronder valt bijvoorbeeld het onjuist declareren bij een ziektekostenverzekeraar.

Uit artikel 47 lid 1 sub a Wet BIG vloeit een algemene hulpverleningsplicht in noodgevallen voort. Deze hulpverleningsplicht geldt ook in het buitenland. Op grond van vaste jurisprudentie van het Centraal Tuchtcollege voor de Gezondheidszorg (CTG) mag van de arts ten minste worden verlangd dat hij in noodsituaties of bij calamiteiten in ieder geval en voor zover mogelijk eerste hulp verleent. ${ }^{84}$ Deze uitspraak kan worden doorgetrokken naar de hulpverlening op Nederlands grondgebied: buiten werk of diensttijd is de arts verplicht om in een noodsituatie of calamiteit eerste hulp te verlenen. ${ }^{85}$ De tuchtrechtelijke hulpverleningsplicht is dan ook alleen relevant bij het weigeren van hulp in noodsituaties en calamiteiten waarbij een vreemdeling betrokken is.

De hierboven besproken straf- en tuchtrechtelijk gesanctioneerde hulpverleningsplicht geldt in beginsel dus alleen voor levensbedreigende situaties.

\subsubsection{Civielrechtelijke hulpverleningsplicht}

De geneeskundige behandelingsovereenkomst is een bijzondere vorm van de overeenkomst tot opdracht. De omschrijving houdt in dat de ene partij - de hulpverlener - zich tegenover de ander - de opdrachtgever - verbindt handelingen op het gebied van de geneeskunst te verrichten die rechtstreeks betrekking hebben op een persoon, aangeduid als de patiënt (artikel 7:446 lid 1 Wgbo). Voor de hulpverleningsplicht zijn drie situaties van belang: het aangaan, de uitvoering en de beëindiging van de overeenkomst. De individuele arts is verantwoordelijk voor het besluit een overeenkomst al dan niet aan te gaan of te beëindigen.

\subsubsection{Aangaan van de overeenkomst}

Leenen wees erop dat de samenleving alleen onder zeer bijzondere omstandigheden kan aanvaarden dat artsen behandeling van patiënten weigeren. ${ }^{86}$ Destijds gold een acceptatieplicht, tenzij inwilliging van een verzoek van een patiënt redelijkerwijs niet van de arts kon worden gevergd. Sijmons constateerde dat het toenmalige stelsel (ZFW/AWBZ) en tarievenstelsel

\footnotetext{
${ }^{84}$ CTG 19 augustus 2010, LJN YG0528, GJ 2010/131, m.nt. L.E. Kalkman-Bogerd.

${ }^{85}$ Kalkman-Bogerd, in: T\&C Gezondheidsrecht 2020, art. 47 lid 1 sub a, Wet BIG.

${ }^{86}$ Leenen e.a. NTvG 1991;135:103-6.
} 
(Wtg) de ziekenhuizen aanleiding gaf de hulpverleningsplicht te beperken. De behandelingsovereenkomst zou geweigerd kunnen worden als tussen een ziekenhuis en ziekenfonds gemaakte productieafspraken zijn bereikt. De zorgplicht zou primair bij de zorgverzekeraar liggen. ${ }^{87}$ Roscam Abbing bracht hiertegen in dat het weigeren van een behandelingsovereenkomst in een dergelijke situatie in strijd zou zijn met het recht op hulp van de verzekerde. ${ }^{88}$ Heeft de overheid de zorgplicht mede bij de zorgverzekeraar gelegd, de KNMG-richtlijn Niet-aangaan of beëindiging van de behandelingsovereenkomst gaat nog steeds uit van een acceptatieplicht. ${ }^{89}$

In bepaalde gevallen kan de arts besluiten om geen overeenkomst aan te gaan. ${ }^{90}$ Het niet kunnen betalen van de rekening wordt daarbij niet genoemd. Sijmons leidde uit de aard van de geneeskundige behandelingsovereenkomst (met een wederkerig karakter) echter af dat betaling als voorwaarde voor contractering (en dus behandeling) kan worden gesteld. ${ }^{91}$ Hij verwees hierbij naar de wetsgeschiedenis van de Wgbo, waarin dit expliciet aan de orde is geweest: 'De niet-verzekerde patiënt moet de kosten van de hulpverlening zelf dragen. Omdat de nietverzekerde patiënt de kosten van de hulpverlening zelf moet dragen, zal vanzelfsprekend de verwachting dat de patiënt hiertoe niet bij machte zal zijn, een valabele reden zijn geen behandelingsovereenkomst aan te gaan. ${ }^{92}$ Een arts mag een patiënt dus weigeren als hij de rekening niet kan betalen, behoudens in acute nood. ${ }^{93}$

De vraag is of deze conclusie ook zonder meer geldt voor de onverzekerbare vreemdeling die niet altijd in staat zal zijn om de rekening te betalen. Naar mijn mening is dat niet het geval. De commissie Klazinga heeft geen uitspraken gedaan over het al dan niet aangaan of voortzetten van een behandelingsovereenkomst. Wel adviseert de commissie dat een arts zich in het algemeen bewust dient te zijn van het kostenaspect van zijn medisch handelen, zonder dat dit een leidend principe mag worden. Financiële argumenten kunnen een rol spelen bij de keuze van behandeling, mits de geldende richtlijnen voor medisch handelen daarvoor ruimte laten. ${ }^{94}$ Op grond van dit advies kan worden gesteld dat het niet-aangaan (of niet-voortzetten) van een geneeskundige behandelingsovereenkomst met een onverzekerbare vreemdeling op grond van financiële overwegingen een extra zorgvuldige afweging vraagt. De behandelingsovereenkomst kan niet zonder meer worden geweigerd. De arts heeft naar mijn mening een inspanningsverplichting om na te gaan of de te verlenen zorg onder de bijdrageregeling valt. Het criterium 'acute nood', dat een uitzondering vormt op de contracteervrijheid, dient in het geval van de onverzekerde vreemdeling te worden verruimd tot

\footnotetext{
${ }^{87}$ Sijmons, TvGR 1995/6, p. 332-345.

${ }^{88}$ Roscam Abbing, TvGR 1995/6, p. 346-347.

89 Niet expliciet, maar impliciet verwoord: 'Een arts kan niet zonder meer besluiten geen behandelingsovereenkomst met een patiënt aan te gaan', KNMG-richtlijn 'Niet-aangaan of beëindiging van de geneeskundige behandelingsovereenkomst' (2005), p. 6.

${ }^{90}$ KNMG-richtlijn 'Niet-aangaan of beëindiging van de geneeskundige behandelingsovereenkomst' (2005), p. 5.

${ }^{91}$ Sijmons, TvGR 1995/6, p. 332-345.

${ }^{92}$ Nota naar aanleiding van het eindverslag Wgbo, Kamerstukken II 21 561, nr. 15, p. 7.

${ }^{93}$ Dit geldt ook voor het weigeren van patiënten op grond van hun verzekeringspolis, indien de verzekeraar kort op budgetten. Zo weigerden twee huisartsen in Noord-Brabant nieuwe patiënten die bij zorgverzekeraar VGZ uit verzekerd waren uit onvrede over de tarieven die VGZ hen bood, Hoekstra, Eindhovens Dagblad 23 november 2019.

${ }^{94}$ Commissie Klazinga, 2007, p. 43.
} 
'medisch noodzakelijke zorg'. 95

Daarnaast speelt nog de identificatieplicht. In Nederland geldt een identificatieplicht in de zorg, behoudens voor acute hulp. Indien een patiënt geen identiteitsbewijs of verblijfsdocument kan tonen, mag dat geen reden zijn om zorg te weigeren.

\subsubsection{De uitvoering van de behandelingsovereenkomst}

Bij de uitvoering van de behandelingsovereenkomst is de arts verplicht de zorg van een goed hulpverlener in acht te nemen en te handelen in overeenstemming met de voor hem geldende professionele standaard. ${ }^{96}$ In de Wgbo is de betalingsverplichting van de patiënt aan de hulpverlener vastgelegd. ${ }^{97}$ Het niet kunnen betalen van de rekening is niet alleen een reden om geen behandelovereenkomst aan te gaan, maar ook om deze te schorsen of te beëindigen.

\subsubsection{De beëindiging van de behandelingsovereenkomst}

De behandelingsovereenkomst kan niet worden opgezegd, behoudens gewichtige redenen. ${ }^{98}$ Een behandelingsovereenkomst kan worden beëindigd als er voortdurend niet wordt betaald. Een enkele weigering om te betalen is geen reden voor beëindiging. De situatie zal zo moeten zijn, dat van de arts in redelijkheid niet kan worden gevraagd de behandelingsovereenkomst met de patiënt voort te zetten. ${ }^{99}$ De arts dient bij eenzijdige beëindiging wel zorgvuldigheidseisen in acht te nemen waaronder herhaaldelijke waarschuwing en een redelijke termijn voor beëindiging. Medisch noodzakelijke zorg dient te worden voortgezet totdat de patiënt een andere arts heeft gevonden en de arts werkt zoveel mogelijk mee aan het zoeken van een alternatief. ${ }^{100}$

\subsubsection{Hulpverleningsplicht van tandartsen ${ }^{101}$}

Ook op tandartsen zijn de straf- en tuchtrechtelijke hulpverleningsplicht van toepassing. Uit artikel 47 lid 1 Wet BIG vloeit een algemene hulpverleningsplicht jegens niet-ingeschreven patiënten in noodgevallen voort. Deze hulpverleningsplicht geldt echter alleen in noodgevallen. ${ }^{102}$

Volgens de internationale gedragsregels dient de tandarts volgens de 'state of the art' en volgens de beginselen van humaniteit hulp te verlenen. Het beschermen van de mondzorg van patiënten is onafhankelijk van diens individuele status. ${ }^{103}$ Tevens zijn op tandartsen algemene gedragsregels van de Koninklijke Nederlandse Maatschappij tot bevordering der Tandheelkunde (KNMT) van toepassing. ${ }^{104}$

\footnotetext{
${ }^{95}$ Gediscussieerd kan worden over de vraag of dit vanuit het gelijkheidsbeginsel ook voor andere onverzekerden zou moeten gelden.

96 Art. 7:453 Wgbo.

97 Art. 7:461 Wgbo.

98 Art. 7:460 Wgbo.

${ }^{99}$ KNMG-richtlijn 'Niet-aangaan of beëindiging van de geneeskundige behandelingsovereenkomst' (2005), p. 7.

${ }^{100}$ KNMG-richtlijn 'Niet-aangaan of beëindiging van de geneeskundige behandelingsovereenkomst' (2005), p. 8.

${ }^{101}$ Zie uitvoeriger over de hulpverleningsplicht van tandartsen Derckx 2018.

102 Vgl. Brands 2006.

${ }^{103}$ International Principles of Ethics for the Dental Profession, september 1997, fdiworlddental.org.

${ }^{104}$ Gedragsregels voor tandartsen, knmt.nl.
} 
In tegenstelling tot artsen, hebben tandartsen geen acceptatie c.q. behandelplicht. Artikel 10 van de gedragsregels geeft hen het recht om patiënten te weigeren. Deze vrijheid kent een aantal beperkingen. Zo mag weigering om een behandelovereenkomst aan te gaan niet in strijd zijn met het discriminatieverbod van artikel $1 \mathrm{Gw}$. Het weigeren van patiënten dient wel zorgvuldig te geschieden. De tuchtrechter ontleent de zorgvuldigheidseisen aan de KNMGrichtlijn 'Niet-aangaan of beëindiging arts-patiëntrelatie' waar ook tandartsen acht op hebben te slaan. ${ }^{105}$ Verder is de contractsvrijheid beperkt door noodgevallen. ${ }^{106}$ De tandarts moet helpen bij noodgevallen en mag zich beperken tot noodhulp. ${ }^{107}$ De behandelingsovereenkomst kan niet worden opgezegd, behoudens gewichtige redenen. ${ }^{108}$ Een behandelingsovereenkomst kan (onder meer) worden beëindigd als er voortdurend niet wordt betaald.

\subsection{Conclusie}

In de context van het recht op medisch noodzakelijke zorg van irreguliere migranten zijn twee verschillende categorieën zorgplichten met ieder een andere functie te onderscheiden. Het betreft ten eerste de zorgplicht van de staat op basis van internationale verdragen om de toegang tot zorg van onrechtmatig verblijvende vreemdelingen te waarborgen en ten tweede de zorgplicht van de hulpverlener op basis van de individuele hulpverleningsplicht. De overheid ging en gaat ervan uit dat deze zorgplichten elkaar dekken, wat niet het geval is.

Volgens de overheid zou de individuele zorgplicht van de zorgverlener voldoende zijn om de medisch noodzakelijke zorg te waarborgen. De medische ethiek noopt de zorgverlener ertoe om geen onderscheid te maken op basis van verblijfsstatus. De straf- en tuchtrechtelijk gesanctioneerde hulpverleningsplicht bestaat uitsluitend in acute nood. Daar komt nog bij dat de zorgverlener de geneeskundige behandelingsovereenkomst mag weigeren in geval van betalingsonmacht. De zorgplichten zwaluwstaarten elkaar dan ook niet. De overheid heeft een deel van haar verantwoordelijkheid - het waarborgen van medisch noodzakelijke zorg afgekoppeld en afgewenteld op de individuele zorgverlener. De overheid heeft de omvang van de te verlenen zorg aan de zorgverlener overgelaten. De interpretatie van laatstgenoemde van het begrip 'medisch noodzakelijke zorg' is cruciaal voor de feitelijke omvang van de te verlenen zorg aan de onrechtmatig verblijvende vreemdeling. Gestreefd dient te worden naar een eenduidige duidelijke interpretatie van het begrip medisch noodzakelijke zorg conform de richtlijn van de commissie Klazinga.

Sommige medisch noodzakelijke zorg valt buiten de bijdrageregeling. Dit is naar mijn mening in beginsel geen reden om de onverzekerbare vreemdeling niet als patiënt te accepteren. Van de arts mag worden verwacht dat hij onderzoekt in hoeverre de behandeling onder de bijdrageregeling valt. Het feit dat maximaal $80 \%$ van de kosten wordt vergoed (behoudens uitzonderingen) mag naar mijn mening geen aanleiding zijn de overeenkomst niet aan te gaan, laat staan om deze op te schorten of te beëindigen.

\footnotetext{
105 Regionaal Tuchtcollege Zwolle d.d. 4 november 2010, ECLI:NL:TGZRWO:2010:YG0644.

${ }^{106}$ NMT-praktijkrichtlijn 'Opvang tandheelkundige spoedgevallen buiten praktijkuren', NMT april 2012, knmt.nl (laatst geraadpleegd 19 mei 2020).

${ }^{107}$ Brands 2006.

108 Art. 7:460 Wgbo.
} 


\title{
Hoofdstuk 6 Recht op zorg voor de gezondheid: internationaal kader
}

\author{
Het jaar 2019 was een (voorlopig) recordjaar voor \\ het aantal wereldwijde vluchtelingen. Volgens de \\ VN Vluchtelingenorganisatie UNHCR waren er in \\ dat jaar 79,5 miljoen mensen op de vlucht voor \\ oorlog en geweld. Voor vluchtelingen zijn de \\ coronamaatregelen praktisch onmogelijk. \\ Noodhulpverlener Paul Borsboom spreekt over de \\ gevolgen van het coronavirus in \\ vluchtelingenkampen: "Die D van dignity wordt \\ steeds belangrijker. Hoe meer vluchtelingen en \\ ontheemden er zijn, hoe meer de wereld alleen \\ maar spreekt over vluchtelingen als \\ mensenmassa's en stromen, en niet als mensen \\ zoals jij en ik, hoe meer hulpverleners die \\ waardigheid van elk individu moeten beschermen. \\ leder mens heeft recht op een waardig bestaan."
}

Bron: www.cordaid.org/nl/nieuws

\subsection{Inleiding}

Om te kunnen toetsen of de uitwerking van het recht op gezondheidszorg van de onrechtmatig verblijvende vreemdeling beantwoordt aan de beoogde rechtsbescherming uit hoofde van internationale verdragen, zal dit hoofdstuk nader exploreren wat de inhoud van dit recht is. Dit hoofdstuk ziet dan ook op de eerste deelvraag: welke aanspraken op gezondheidszorg hebben vreemdelingen die onrechtmatig in Nederland verblijven ten principale?

Het onderzoek vindt plaats vanuit internationaal gezondheidsrechtelijk perspectief. Er vindt analyse plaats van de internationale, regionale en supranationale verdragen en aanbevelingen die zien op het recht op (zorg voor de) gezondheid of daaraan gerelateerd zijn. Onder de laatste vallen andere fundamentele mensenrechten zoals het recht op leven en het recht op privacy. Positieve verplichtingen die daaruit voortvloeien geven immers mede vorm aan het recht op zorg voor de gezondheid.

Het is niet vanzelfsprekend gebleken dat ook irreguliere migranten (niet-staatsburgers zijnde) onder de personele reikwijdte van de verschillende internationale instrumenten vallen. Per instrument zal de personele reikwijdte worden besproken. Ook vindt een bespreking plaats van relevante uitspraken van internationale (quasi-)rechterlijke instanties. Daarnaast zijn er 
specifieke, voor (irreguliere) migranten ontworpen verdragen en aanbevelingen. Specifieke aandacht gaat uit naar het recht op gezondheid van onrechtmatig verblijvende kinderen.

Vervolgens wordt onderzocht in hoeverre staten het recht op (toegang en/of financiering van) zorg voor de gezondheid mogen beperken op basis van verblijfsstatus. Na een eerste verkenning van het recht op zorg voor de gezondheid - in het bestek van dit proefschrift kan niet de gehele doctrine worden besproken - richt het hoofdstuk zich op de specifiek op irreguliere migranten toegesneden verplichtingen.

\subsection{Het recht op (zorg voor) de gezondheid}

\subsubsection{Inleiding}

Deze paragraaf bespreekt de aard en grondslagen van het recht op zorg voor de gezondheid en de specifiek op de irreguliere migrant toegespitste internationale instrumenten.

\subsubsection{Aard en universele werking van het recht}

Het recht op (zorg voor) de gezondheid is verankerd in het mensenrechteninstrumentarium en in regionale verdragen. Het recht op gezondheid is een fundamenteel mensenrecht, onontbeerlijk voor de uitoefening van andere mensenrechten, zoals - en met name - het recht om een waardig leven te leiden. ${ }^{1}$ Rondom sociale (en culturele) rechten, zoals het recht op gezondheid, hangt nog vaak een zweem van 'luxe', van een norm waar naar wordt gestreefd in plaats van een juridische norm. Er is in de mensenrechtendoctrine echter allang geen sprake meer van een strikte scheiding tussen de burgerlijke en politieke rechten enerzijds en economische, sociale en culturele rechten anderzijds. In 1993 benadrukten staten in de Vienna Declaration of Human Rights dat "all human rights are universal, indivisible and interdependent and interrelated". ${ }^{2}$ De kernverplichtingen van het recht op zorg voor de gezondheid worden inmiddels echter gezien als behorend tot internationaal gewoonterecht of zelfs tot erkende algemene rechtsbeginselen. ${ }^{3}$ De kernverplichtingen kunnen direct worden ingeroepen bij de nationale rechter. Staten dienen niet alleen het recht op zorg voor de gezondheid te respecteren, zij dienen deze ook te bevorderen. Dit vergt positieve maatregelen.

Het recht op gezondheid is een universeel erkend sociaal mensenrecht dat - evenals andere mensenrechten - is gebaseerd op het principe van waardigheid en intrinsieke gelijkheid van alle mensen. Desondanks is de universele werking van het recht (in die zin dat ook irreguliere migranten hier aanspraken aan kunnen ontlenen) controversieel gebleken. Zo bepaalde de resolutie van de Algemene Vergadering van de VN over mensen-

\footnotetext{
${ }^{1}$ UN Committee on Economic, Social and Cultural Rights, General comment No 14: The Right to the Highest Attainable Standard of Health (art. 12), 22nd Sess, UN Doc E/C/.12/2000/4 (11 August 2000), par. 1, Riedel 2009, p. 21, UN Gerenal Assembly, Report of the Special Rapporteur on the Right of Everyone to the Enjoyment of the Highest Attainable Standard of Physical and Mental Health, 69th Sess, UN Doc E/1990/23 (2 February 1990).

${ }^{2}$ World Conference on Human Rights, Vienna Declaration and Programme of Action, A/CONF/157/2 (12 July 1993, paragrafen 5 en 75.

3 Aldus rechter Pinto de Albuquerque in zijn gedeeltelijke dissenting opinion bij EHRM 19 december 2017, ECLI:CE:ECHR:2017:1219JUD005608013, EHRC 2018/47, m.nt. L. Lavrysen (Lopes de Sousa Fernandes/ Portugal), par. 27, onder verwijzing naar Riedel 2009, p. 32. In de zaak Lopes de Sousa Fernandes/Portugal was volgens het EHRM sprake van (materiële) schending van art. 2 EVRM vanwege onvoldoende samenwerking tussen professionals in de zorg.
} 
rechtenbescherming voor niet onderdanen uit 1985 dat het recht op de daarin genoemde sociale rechten zoals het recht op gezondheidsbescherming en medische zorg voorbehouden is aan vreemdelingen die rechtmatig op het grondgebied van een staat verblijven. ${ }^{4}$ Deze resolutie, die niet is omgezet in een juridisch bindend instrument, is wel aangevoerd als argument dat mensenrechtenbescherming alleen van toepassing is op onderdanen die rechtmatig in een land verblijven. ${ }^{5}$ Het enige internationale verdrag dat expliciet bepaalt dat irreguliere migranten recht hebben op medische zorg (het VN-Arbeidsmigrantenverdrag) is door geen enkele EUlidstaat geratificeerd, hetgeen illustratief is voor de terughoudendheid van (Westerse) staten om dit recht te erkennen. ${ }^{6}$ Dit zal worden uitgediept bij het bespreken van de personele reikwijdte van de verdragen waarin het recht op zorg voor de gezondheid is vastgelegd.

\subsubsection{Wereldgezondheidsorganisatie}

\subsubsection{Bevorderen van de gezondheid}

De eerste verwijzing naar een algemeen recht op zorg voor de gezondheid is gelegen in de Constitutie van de Wereldgezondheidsorganisatie (WHO) in 1946. De WHO, onderdeel van de Verenigde Naties (VN), is een internationale organisatie met een officiële Europese tak, de WHO-EUR. Doel van de WHO is (kort gezegd) de bevordering van de gezondheid in de wereld. Zoals we al zagen in paragraaf 2.3.1, interpreteert de WHO gezondheid als een staat van welzijn op fysiek, mentaal en sociaal niveau, niet slechts als de afwezigheid van ziekte of gebrek. ${ }^{7}$ De WHO is op basis van haar Constitutie (WHO-Grondwet, 1946) bevoegd om verdragen te sluiten, bindende richtlijnen uit te vaardigen en aanbevelingen te doen. ${ }^{8}$

\subsubsection{Personele reikwijdte}

De oprichting van de WHO werd beschouwd als wellicht wel de meest bemoedigende uiting van de internationale solidariteit na de Tweede Wereldoorlog. ${ }^{9}$ Het bevorderen van de gezondheid en welzijn van alle volken stond voorop:

"The members of the one-time Health Committee and its staff have deep satisfaction in the certainty that its pioneer work will be carried forward, under the most favorable auspices, to a conclusion fraught with the benefits of fuller and more abundant health for all the peoples of our "One World". 10

Deze universele benadering kwam verder tot uiting in considerans van de WHO-Grondwet, waarin staat dat het genot van een zo hoog mogelijke standaard van gezondheid een

\footnotetext{
${ }^{4}$ Resolution 40/144 General Assembly United Nations (13 December 1985), on the Human Rights of Individuals Who are Not Nationals of the Country in Which They Live.

${ }^{5}$ Volgens Cholewinski weerspiegelt deze aanbeveling de spanning die bestaat tussen het principe van universele mensenrechtenbescherming en de praktische toepassing van zulke rechten tot niet onderdanen in het algemeen en mensen zonder rechtmatig verblijf in het bijzonder, Cholewinski 2005, p. 27.

${ }^{6}$ Internationaal Verdrag ter bescherming van alle arbeidsmigranten en van hun familieleden, New York (18 December 1990), UNTS nr. 39481.

${ }^{7}$ Preambule van de Wereldgezondheidsorganisatie, New York, 22-07-1946.

${ }^{8}$ Zie over deze bevoegdheden Toebes 2016.

9 “A Magna Carta for World Health", American Journal of Public Health 1946/9, p. 1041-1045.

10 “A Magna Carta for World Health”, American Journal of Public Health 1946/9, p. 1041-1045.
} 
fundamenteel recht is van ieder mens zonder onderscheid van ras, religie, politieke overtuiging, economische of sociale conditie. 'Nationale afkomst', 'nationaliteit' of 'verblijfsstatus' zijn niet expliciet als grond genoemd waarop geen onderscheid mag worden gemaakt. ${ }^{11}$ Dat voornoemde opsomming echter niet als limitatief kan worden beschouwd, kan worden afgeleid uit de intenties van de grondleggers en het uitgangspunt van de WHO: 'gezondheid voor iedereen'. Dit uitgangspunt komt voorts tot uitdrukking in diverse aanbevelingen van de WHO, waaronder de 1978 Alma-Ata Verklaring over Primary Health Care. ${ }^{12}$

Het principe van Universal Health Coverage (UHC) is gebaseerd op de Alma-Ata verklaring. UHC is onderdeel van de VN-Sustainable Development Goals (SDGs), Werelddoelen voor duurzame ontwikkeling (tot 2015 milleniumdoelen). Uitgangspunt van UHC is dat iedere wereldburger toegang heeft tot de gezondheidsdiensten die hij nodig heeft (preventie, promotie, behandeling, rehabilitatie en palliatieve zorg) zonder financiële risico's. ${ }^{13}$ Non-discriminatie is een belangrijk uitgangspunt van UHC. UHC kan volgens de WHO niet worden bereikt als niet tegemoet wordt gekomen aan de gezondheidsbehoeften van vluchtelingen en migranten. ${ }^{14}$ Ook al betreffen de werelddoelen alleen na te streven doelen voor de gezondheidszorg en zijn het geen juridisch afdwingbare verplichtingen, toch kunnen deze voor de interpretatie van sociale rechtvaardigheid in de toekomst steeds belangrijker worden. ${ }^{15}$ Volgens Ingleby \& Petrova-Benedict zijn veel overheden echter in paradoxale zin aan het beginsel van UHC gecommitteerd: zij ondersteunen deze, zolang zij het maar niet op iedereen hoeven toe te passen. ${ }^{16}$

\subsubsection{Recht op zorg voor gezondheid voor irreguliere migranten}

Er zijn op WHO-niveau een aantal resoluties en aanbevelingen verschenen die betrekking hebben op het promoten van de gezondheid van migranten. ${ }^{17}$ Irreguliere migranten vallen daar ook onder. Kort samengevat neemt de WHO de hoogst mogelijke standaard van fysieke en mentale gezondheid, gelijkheid en non-discriminatie en gelijke toegang tot gezondheidsdiensten van irreguliere migranten als uitgangspunt. De ongelijkheid in gezondheid dient te worden verminderd en lidstaten dienen een migrant-sensitief beleid te voeren. Irreguliere migranten hebben hetzelfde recht op gezondheid als ieder ander. Resoluties zijn niet

\footnotetext{
11 Nationaliteit en nationale afkomst zijn geen synoniemen en worden vaak als aparte verboden discriminatiegronden genoemd.

${ }^{12}$ Declaration of Alma-Ata. International Conference on Primary Health Care, Alma-Ata, USSR, 6-12 September 1978.

${ }^{13}$ UN General Assembly, Global health and foreign policy, UN Doc. A./67/L.36 (2012), par. 10.

14 WHO 2018a.

${ }^{15}$ Ooms e.a., BMC International Health and Human Rights 2014/3, andere literatuur over dit onderwerp: Forman e.a., Health and Human Rights Journal 2014/2, p. 23-24, Dalli, International Journal of Minority and Group Rights 2018/2, p. 1-17 en Onarheim e.a., BMJ Global Health 2018;3:e001031.

${ }^{16}$ Ingleby \& Petrova-Benedict 2016, p. 29.

${ }^{17}$ Resolution WHA61.17. Health of migrants. In: Sixty-first World Health Assembly, Geneva, 16-24 May 2008. Geneva: World Health Organization; 2008; WHO Regional Committee for Europe $66^{\text {th }}$ Session, Strategy and action plan for refugee and migrant health in the WHO European Region, EUR/RC66/8, +EUR/RC66/Conf.Doc./4, WHO Framework of Priorities and Guiding Principles to Promote the Health of Refugees and Migrants, 2016, WHO Regional Committee for Europe, Toolkit for assessing health system capacity to manage large influxes of refugees, asylum-seekers and migrants, 2016, Resolution WHA70.15. Promoting the health of refugees and migrants. In: Seventieth World Health Assembly, Geneva, 23-31 May 2017; WHO 2018a en WHO 2018b.
} 
bindend voor de staten van de VN. De irreguliere migrant kan er dan ook geen juridisch afdwingbare aanspraken aan ontlenen ondanks deze heldere boodschap.

\subsubsection{Universele Verklaring voor de Rechten van de Mens}

\subsubsection{Recht op adequate levenstandaard}

Een volgende grondslag van het recht op gezondheidszorg ligt besloten in de Universele Verklaring voor de Rechten van de Mens (UVRM, 1948). ${ }^{18}$ De Resolutie kent geen artikel voor het recht op zorg voor de gezondheid als zodanig maar bevat wel het recht van iedereen, zonder discriminatie, op een levensstandaard hoog genoeg voor gezondheid en welzijn. ${ }^{19}$ Legt de UVRM hiermee het recht van iedereen op gezondheidszorg vast, de interpretatie van 'gezondheid' is open gebleven, evenals de wijze van implementatie ervan. ${ }^{20}$ Ook al is de Resolutie niet bindend, algemeen wordt aangenomen dat (het grootste deel van) de in de UVRM opgenomen rechten de status hebben van internationaal gewoonterecht. ${ }^{21}$ Dat betekent dat niet-bindende bepalingen alsnog bindend zijn geworden door opname in verdragsrecht. De algemene principes van de UVRM zijn verder uitgewerkt in het Internationaal Verdrag inzake burgerrechten en politieke rechten (IVBPR) en het Internationaal Verdrag inzake economische, sociale en culturele rechten (IVESCR). ${ }^{22}$

\subsubsection{Personele werkingssfeer}

Volgens artikel 2 van het UVRM heeft een ieder aanspraak op alle rechten en vrijheden van de Verklaring, zonder onderscheid van welke aard. Uit de tekst van de Verklaring kan niet worden afgeleid of vreemdelingen ook onder 'een ieder' vallen. Onder de gronden waarop geen onderscheid mag worden gemaakt, wordt 'nationaliteit' als zodanig niet genoemd. In het licht van het universaliteitsbeginsel, kan dit volgens Grant echter niet worden gezien als rechtvaardiging om onderscheid te maken tussen onderdanen en vreemdelingen. Uit de ontwerpgeschiedenis van de verklaring, de algemene benadering van vreemdelingen in internationaal recht ten tijde van de aanvaarding van de verklaring en het principe 'dignity' in artikel 1 UVRM leidt zij af, dat het de bedoeling was om vreemdelingen te includeren onder de werking van het UVRM. ${ }^{23}$

\subsubsection{Algemene mensenrechtenverdragen}

6.2.5.1 Internationaal Verdrag inzake burgerrechten en politieke rechten (IVBPR)

\subsection{Recht op leven}

\footnotetext{
${ }^{18}$ Universele Verklaring van de Rechten van de Mens, New York, 10-12-1948.

${ }^{19}$ Art. 25 UVRM.

${ }^{20}$ Roscam Abbing 1979, p. 69.

${ }^{21}$ Coomans \& Kamminga 2007, p. 8.

${ }^{22}$ Internationaal Verdrag inzake burgerrechten en politieke rechten, New York, 16-12-1966 resp. Internationaal Verdrag inzake economische, sociale en culturele rechten, New York, 16-12-1966.

${ }^{23}$ Grant 2011.
} 
Het fundamentele recht op leven (artikel 6 IVBPR) is nauw verbonden met het recht op zorg voor de gezondheid. Ziekte zonder zorg kan immers leiden tot voortijdig overlijden. Het is vaste jurisprudentie van het VN-Mensenrechtencomité - belast met de handhaving van de IVBRP dat het recht op leven het nemen van positieve maatregelen vereist, waaronder, indien nodig, het verzekeren van onmiddellijke toegang tot essentiële voorzieningen zoals gezondheidszorg. ${ }^{24}$ In General Comment No. 6 bevestigt het VN-Mensenrechtencomité deze ruime uitleg van het recht op leven. ${ }^{25}$ Daarnaast wordt het bereik van het recht op leven uitgebreid door de notie van menselijke waardigheid onder het recht op leven te scharen en deze te linken aan maatregelen op het sociaaleconomisch terrein. ${ }^{26}$ De verplichting om het leven te beschermen impliceert mede dat staten passende maatregelen moeten nemen om algemene omstandigheden in de samenleving aan te pakken die kunnen leiden tot directe bedreigingen van het leven en het beletten van het genot van individuen van hun recht op leven in waardigheid. Hieronder valt bijvoorbeeld het voorkómen van levensbedreigende ziektes zoals AIDS, tuberculose en malaria, maar ook het verzekeren van toegang zonder vertraging van individuen tot gezondheidszorg. ${ }^{27}$ Het is niet duidelijk of omstandigheden pas onder artikel 6 kunnen vallen als zij zowel levensbedreigend als in strijd met de menselijke waardigheid zijn (dus cumulatieve vereisten) of dat het Comité hiermee een zelfstandig recht op leven in waardigheid heeft gecreëerd. ${ }^{28}$ De tekst van de aanbeveling wijst in mijn opinie op een zelfstandig recht ('It concerns the entitlement of individuals to be free from acts and omissions that are intended or may be expected to cause their unnatural of premature death, as well as to enjoy a life with dignity (...)' (cursivering VD). Is dat laatste het geval, dan zal het onnodig lijden aan een ernstige ziekte zonder direct stervensgevaar (bijvoorbeeld vanwege barrières in toegang tot de zorg) in strijd kunnen zijn met het recht op leven.

\subsection{Personele werkingssfeer en discriminatieverbod}

De personele werkingssfeer van het IVBPR is neergelegd in artikel 2: iedere verdragsluitende staat dient de rechten te eerbiedigen aan 'een ieder die binnen zijn grondgebied verblijft en aan zijn rechtsmacht is onderworpen, zonder onderscheid van welke aard ook (...)'. De staat dient het recht op leven te respecteren en te verzekeren van iedereen die zich op zijn grondgebied begeeft en een ieder die onder zijn jurisdictie valt. ${ }^{29}$ Het VN-Mensenrechtencomité heeft nadrukkelijk verklaard dat vrijwel alle burger- en politieke rechten - dus ook het recht op leven - gegarandeerd dienen te worden zonder onderscheid tussen onderdanen en niet-onderdanen. ${ }^{30}$

Daarnaast is het recht op non-discriminatie (artikel 26) van belang voor de bescherming van het recht op gezondheidszorg van irreguliere migranten. Dit discriminatieverbod staat los

\footnotetext{
${ }^{24}$ HRC, General comment No. 36, Article 6 (Right to Life), 3 September 2019. CCPR/C/GC/35, par. 26.

${ }^{25}$ HRC, General comment No. 36 (supra noot 24), par. I.3.

${ }^{26}$ HRC, General comment No. 36 (supra noot 24), par. 3.

${ }^{27}$ HRC, General comment No. 36 (supra noot 24), para. 26.

${ }^{28}$ Joseph daarentegen acht de eerste interpretatie plausibel, Joseph, Human Rights Law Review 2019/2, p. 347368. Volgens haar verdient het de voorkeur om art. 6 zo te interpreteren dat het ingaat op die omstandigheden die een plausibele bedreiging vormen voor het leven en tegelijkertijd de waardigheid ondermijnen. Dit leidt zij onder meer af uit het feit dat het recht op leven in waardigheid kan worden gevonden in combinatie met een reeks andere mensenrechten.

${ }^{29}$ HRC, General Comment No. 36 (supra noot 24), para. 63.

${ }^{30}$ HRC, General Comment No. 15: The Position of Aliens Under the Covenant, 11 April 1986, paras. 1-2.
} 
van de personele werking van het Verdrag en is als autonoom recht van toepassing op alle regulering van de overheid en de toepassing ervan. ${ }^{31}$ Ongelijke behandeling van gelijke gevallen is alleen toegestaan als er voor de ongelijke behandeling een objectieve en redelijke rechtvaardiging bestaat ter verwezenlijking van een doelstelling die legitiem is onder het Verdrag. ${ }^{32}$

Zowel het recht op leven als het recht op non-discriminatie waren aan de orde in een klacht bij het VN-Mensenrechtencomité van Toussaint/Canada. ${ }^{33}$ De feiten in deze zaak waren als volgt. Klaagster verbleef in Canada zonder een verblijfsvergunning en was bezig met een aanvraag voor een permanente verblijfsstatus op basis van humanitaire redenen. Zij werd gediagnostiseerd met onder meer een longembolie en haar gezondheidstoestand ging drastisch achteruit, waardoor zij medische zorg behoefde. Klaagsters beroep op financiering uit het speciale gezondheidsprogramma voor immigranten van Canada ('Interim Federal Health Program') werd echter afgewezen omdat zij op dat moment niet onder de dekking van dit programma viel. Het VN-Mensenrechtencomité oordeelde dat Canada zowel artikel 6 als artikel 26 IVBRP had geschonden door de aanvraag van Toussaint te weigeren. Volgens het VNMensenrechtencomité hebben ook irreguliere migranten een inherent recht op leven. Staten mogen bij het respecteren en beschermen van dat leven geen onderscheid maken tussen reguliere en irreguliere migranten. De bijzondere omstandigheden van het geval in aanmerking nemend, te weten dat de uitsluiting van het IFHP kon leiden tot de dood of onomkeerbare gezondheidsschade, oordeelde het VN-Mensrechtencomité dat het onderscheid gemaakt dat de Canadese overheid maakte voor toewijzing van IFHP tussen mensen met een wettelijk verblijf in het land en degene die nog niet volledig zijn toegelaten, niet gebaseerd was op redelijke en objectieve criteria en daarmee in strijd met het discriminatieverbod. ${ }^{34}$

6.2.6 Internationaal Verdrag inzake economische, sociale en culturele rechten (IVESCR)

\subsubsection{Recht op een zo goed mogelijke lichamelijke en geestelijke gezondheid}

De kernbepaling van het recht op zorg voor de gezondheid is vervat in artikel 12 lid 1 van het IVESCR (1966): "De Staten die partij zijn bij dit Verdrag erkennen het recht van een ieder op een zo goed mogelijke lichamelijke en geestelijke gezondheid". Lid 2 bevat een niet-limitatieve opsomming van de maatregelen die Staten dienen te nemen om dit recht te verwezenlijken. Gezaghebbend is General Comment No. 14 van het VN-comité voor economische, sociale en culturele rechten (Engels: Committee on Economic, Social and Cultural Rights (CESCR)). Hierin licht de CESCR - het VN-orgaan dat toeziet op de uitvoering van het IVESCR - de omvang van het recht op gezondheid toe. Het recht op gezondheid betreft zowel vrijheden als aanspraken. ${ }^{35}$ Het betreft niet alleen het recht op tijdige en passende gezondheidszorg, maar

\footnotetext{
${ }^{31}$ HRC, General Comment No. 18: Non-discrimination, 10 November 1989, par. 12.

32 Onder meer VN-Mensenrechtencomité 9 april 1987, 172/1984 (Broeks/Nederland), par. 13; VNMensenrechtencomité 9 april 1987, 182/1984 (Zwaan-de Vries/Nederland), par. 13 en VN-Mensenrechtencomité 14 september 2006, 1314/2004 (O'Neill and Quinn/Ierland), par. 8.3.

${ }^{33}$ VN-Mensenrechtencomité 7 augustus 2018, 2348/2014 (Toussaint/ Canada).

${ }^{34}$ VN-Mensenrechtencomité 7 augustus 2018, 2348/2014 (Toussaint/ Canada), par. 11.8.

${ }^{35}$ In deze paragraaf gebruik ik de internationale term 'recht op gezondheid', aangezien dit als zodanig is verwoord in art. 12 lid 1 IVESCR.
} 
ook op onderliggende determinanten van gezondheid, zoals toegang tot veilig water, sanitair en voedsel en educatie en informatie over gezondheid. Deze determinanten weerspiegelen de verbondenheid van het recht op zorg voor de gezondheid met andere mensenrechten. ${ }^{36}$ Het recht op gezondheid wordt dan ook gedifferentieerd in het recht op gezondheidszorg en andere rechten zoals huisvesting, onderwijs en voedsel.

Staten dienen de beschikbaarheid, toegankelijkheid, geschiktheid en kwaliteit van de geboden zorg te garanderen. ${ }^{37}$ Toegankelijkheid bevat vier beginselen: non-discriminatie in de zorg, bereikbaarheid (fysieke toegankelijkheid) en betaalbaarheid van de zorg, alsmede de toegang tot informatie rond de geboden zorg. De staten dienen te voldoen aan de zogenoemde 'tripartite typologie' van verplichtingen: de verplichting te respecteren, te beschermen en te verwezenlijken. ${ }^{38}$ De verplichting om te respecteren omvat de verplichting om het recht op gezondheid te eerbiedigen, onder meer door alle personen inclusief illegale migranten gelijke toegang tot preventieve, curatieve en palliatieve gezondheidsdiensten te ontzeggen of deze te beperken. ${ }^{39}$ De verplichting om te beschermen omvat de verplichting van de staat om wetgeving vast te stellen of andere maatregelen te nemen om gelijke toegang tot de gezondheidszorg en aanverwante diensten te waarborgen en te verwezenlijken en de verplichting om ervoor te zorgen dat artsen en andere gezondheidswerkers voldoen aan passende normen op het gebied van onderwijs, vaardigheden en ethische gedragscodes. ${ }^{40}$ De verplichting om te verwezenlijken omvat onder meer de verplichting om een voldoende aantal ziekenhuizen, klinieken en andere gezondheidsgerelateerde faciliteiten ter beschikking te stellen. ${ }^{41}$

Staten hebben de verplichting om de economische, sociale en culturele rechten progressief te verwezenlijken. ${ }^{42}$ Er wordt rekening gehouden met de financiële mogelijkheden van een land. Retrogressieve maatregelen, bijvoorbeeld het beperken van toegang tot gezondheidzorg voor irreguliere migranten zonder adequate rechtvaardiging, is hoogstwaarschijnlijk in strijd met deze verplichting. Economische recessie vormt als zodanig onvoldoende rechtvaardiging voor een regressieve maatregel. ${ }^{43}$ De progressieve realisering is geen programmatische verplichting, maar een heldere en onmiddellijke verplichting voor de lidstaat. ${ }^{44}$

Het recht op gezondheid bevat een aantal minimum kernverplichtingen ('minimum core obligations'). Een kernverplichting is een minimumverplichting waarvan niet mag worden afgeweken, ongeacht de beschikbaarheid van financiële en andere hulpbronnen. De kernverplichtingen zijn het recht op toegang tot adequate gezondheidszorgvoorzieningen, goederen en diensten zonder discriminatie, het recht op spoed en primaire medische zorg en

\footnotetext{
${ }^{36}$ CESCR General Comment No. 14 (supra noot 1), par. 34.

${ }^{37}$ Availability, Accessibility, Acceptability and Quality, General Comment No. 14, 2000 (supra noot 1), par. 12.

${ }^{38}$ CESCR, General Comment No. 3 (1990): The Nature of State Obligations, UN Doc. E/1991/123, par. 9.

${ }^{39}$ CESCR General Comment No. 14 (supra noot 1), par. 34.

${ }^{40}$ CESCR General Comment No. 14 (supra noot 1), par. 35.

${ }^{41}$ CESCR General Comment No. 14 (supra noot 1), par. 36.

${ }^{42}$ Art. 2(1) IVESCR.

${ }^{43}$ Den Exter, Diametros 2017/51, p. 1730-195. Hij refereert hierbij aan de zogenoemde 'Spanish case', de maatregel van de Spaanse overheid in 2012 die de toegang van irreguliere migranten beperkte tot medische spoedzorg (Royal Decree 16/2002).

${ }^{44}$ Riedel 2009, p. 30.
} 
essentiële medicijnen. ${ }^{45}$ Deze kern is niet onderhevig aan de progressieve realisatie of aan financiële beperkingen. Beperkingen van het recht op zorg voor de gezondheid van irreguliere migranten mag niet leiden tot aantasting van deze kern.

De overheidsverplichtingen die uit het IVESCR voortvloeien hebben volgens Nederlandse rechtspraak geen rechtstreeks werking, omdat de normen onvoldoende concreet zijn. ${ }^{46}$ Toch zou het recht op gezondheid bij helder gedefinieerde verplichtingen afdwingbaar kunnen zijn, aldus Toebes, bijvoorbeeld als de staat structureel tekortschiet in het bieden van adequate gezondheidsvoorzieningen aan irreguliere migranten. ${ }^{47}$

\subsubsection{Personele werkingssfeer en discriminatieverbod IVESCR}

Het IVESCR spreekt in artikel 12 van 'een ieder'. Het CESCR heeft irreguliere migranten hier expliciet onder geschaard: staten zijn verplicht om (inter alia) irreguliere migranten het recht op preventieve, curatieve en palliatieve zorg te verzekeren. ${ }^{48}$ Staten dienen obstakels die het genot van economische, sociale en culturele rechten in de weg staan weg te nemen en zij dienen te verzekeren dat zij het recht van niet-onderdanen op een adequate standaard van fysieke en mentale gezondheid respecteren, onder meer door zich te onthouden om de toegang tot preventieve, curatieve en palliatieve gezondheidszorg te verhinderen of te beperken. ${ }^{49}$

De antidiscriminatiebepaling (artikel 2 IVESCR) bevat een verbod op discriminatie wegens (onder meer) 'nationale of maatschappelijke afkomst' en 'andere status'. Iedere staat beschikt over een zekere mate van discretionaire bevoegdheid om te bepalen welke maatregelen hij neemt om het recht op zorg progressief te verwezenlijken. Het nemen van deze maatregelen mag echter niet tot discriminatie leiden. Ieder onderscheid, uitsluiting, beperking of bevoorrechting dient in overeenstemming te zijn met de wet, dient een legitiem doel te dienen en proportioneel te zijn met het doel dat het dient. Een tekort aan beschikbare bronnen wordt in beginsel niet beschouwd als objectieve en redelijke rechtvaardiging voor een onderscheid in behandeling. ${ }^{50}$ Het beperken van het recht op gezondheid op basis van verblijfsstatus kan dus in overeenstemming zijn met het IVESCR, mits aan deze voorwaarden wordt voldaan en de irreguliere migrant een minimum aan rechten op gezondheidszorg heeft.

\subsubsection{Specifieke VN-verdragen}

Het Verdrag inzake de uitbanning van alle vormen van discriminatie van vrouwen (VNVrouwenverdrag) concentreert zich op gelijke toegang tot medische zorg voor vrouwen en de bescherming van de gezondheid en veiligheid in arbeidsomstandigheden. ${ }^{51}$ Pre- en postnatale

\footnotetext{
${ }^{45}$ CESCR General Comment No. 14 (supra noot 1), par. 43.

${ }^{46}$ Onder meer ABRvS, 19 april 2007, LJN-nr. BA4289, r.o. 2.5.1.

47 Toebes 2001, p. 181.

${ }^{48}$ CESCR General Comment No. 14 (supra noot 1), par. 34 en CESCR 13 maart 2017, Duties of States towards refugees and migrants under the International Covenant on Economic, Social and Cultural Rights, E/C.12/2017/1.

${ }^{49}$ CESCR 13 maart 2017, Duties of States towards refugees and migrants under the International Covenant on Economic, Social and Cultural Rights, E/C.12/2017/1, par. 12.

${ }^{50}$ CESCR General Comment No. 20, Non-discrimination in economic, social and cultural rights (art. 2, para. 2, of the International Covenant on Economic, Social and Cultural Rights), onder 30.

${ }^{51}$ Artikelen 11 en 12.
} 
zorg dienen gratis te worden aangeboden in staten. ${ }^{52}$

Het Internationaal Verdrag inzake de Rechten van het Kind (IVRK) erkent het recht op de grootst mogelijke gezondheid van het kind en bevat een uitvoerige bepaling over de maatregelen die de staten (onder meer) dienen te nemen (zie paragraaf 6.4.1). ${ }^{53}$

Het VN-Verdrag inzake personen met een handicap erkent het recht op het genot van het hoogst haalbare niveau van gezondheid van mensen met een handicap zonder discriminatie op grond van hun handicap. De staten dienen alle passende maatregelen te treffen om personen met een handicap de toegang te waarborgen tot diensten op het gebied van sekse specifieke gezondheidszorg, met inbegrip van revalidatie. ${ }^{54}$

6.2.8 Het recht op zorg voor de gezondheid van irreguliere migranten

De notie dat alle migranten, zowel reguliere als irreguliere, recht hadden op bescherming van hun fundamentele rechten leidde tot de totstandkoming van het eerder genoemde VNArbeidsmigrantenverdrag. ${ }^{55}$ Kritiek op het verdrag is dat het irreguliere migranten een te beperkt recht op zorg biedt, te weten alleen dringend noodzakelijke medische zorg ('emergency medical care') en geen preventieve zorg zoals vroege diagnose en medische follow-up of palliatieve zorg. ${ }^{56}$ Minder dan een kwart van de VN-lidstaten is partij bij het verdrag. Het feit dat geen enkele EU-lidstaat dit verdrag heeft geratificeerd hangt enerzijds samen met het hoge beschermingsniveau van het verdrag en anderzijds met de expliciete bescherming van irreguliere arbeidsmigranten. ${ }^{57}$

Het louter aanwezig zijn van irreguliere migranten schept volgens de CESCR verplichtingen voor de overheid. Om de toegang tot gezondheidszorg te garanderen zonder discriminatie, dienen strikte muren te bestaan tussen gezondheidszorgmedewerkers en rechtshandhavers. Er dient adequate informatie beschikbaar te zijn in de talen die het meeste voorkomen in het gastland, om te voorkomen dat (irreguliere) migranten vermijden om medische hulp te zoeken en te verkrijgen. Verder roept het Comité lidstaten op om data te verzamelen die nodig zijn om te onderzoeken of irreguliere migranten van hun sociale rechten kunnen genieten en of de lidstaten aan hun verplichtingen op grond van het IVESCR kunnen genieten. ${ }^{58}$

\subsection{Raad van Europa}

6.3.1 Europees Sociaal Handvest (herzien): Recht op bescherming van gezondheid en sociale en geneeskundige bijstand

Het Europees Sociaal Handvest (herzien) (ESH (herzien)) bevat het recht op bescherming van de gezondheid in die zin dat lidstaten 'passende maatregelen' dienen te nemen om het recht op

\footnotetext{
${ }^{52}$ Verdrag inzake de uitbanning van alle vormen van discriminatie van vrouwen, New York (18 December 1979), art. 12 lid 2.

${ }^{53}$ Verdrag inzake de rechten van het kind, New York (20 November 1989), art. 24 lid 1.

${ }^{54}$ Art. 25.

55 VN-Arbeidsmigrantenverdrag (supra noot 6).

56 Zie Pace 2009, p. 28.

${ }^{57}$ Wouters \& M. Vidal 2005, p. 1.

${ }^{58}$ Committee on Economic, Social and Cultural Rights, 13 maart 2017, Duties of States towards refugees and migrants under the International Covenant on Economic, Social and Cultural Rights.
} 
zorg voor de gezondheid te waarborgen. ${ }^{59}$ Daarnaast legt het ESH (herzien) het recht op sociale en geneeskundige bijstand vast. Lidstaten dienen onder meer te waarborgen dat een ieder die ontoereikende inkomsten heeft en niet in staat is zulke middelen te verwerven, door uitkeringen voldoende bijstand verkrijgt en in geval van ziekte de voor zijn toestand vereiste verzorging geniet. $^{60}$

In de klacht FIDH/France achtte het Europees Comité voor Sociale Rechten (ECSR), dat toeziet op naleving van het ESH (herzien), (zij het aarzelend) het nog voldoende dat 'enige vorm van medische bijstand' toekwam aan irreguliere migranten. ${ }^{61}$ Een paar jaar later leest het ECSR in artikel 13 lid 1 ESH (herzien) een aantal minimum aanspraken op zorg waarvan het genot door verdragsstaten dient te worden gegarandeerd. ${ }^{62}$ Medische bijstand kan niet worden beperkt tot medische noodhulp, maar omvat tevens eerstelijns, ziekenhuis en poliklinische zorg. Wat de concrete invulling van deze interpretatie precies inhoudt is niet duidelijk. ${ }^{63}$ De strikte interpretatie van 'medische noodhulp' lijkt te evolueren naar een meer flexibele waarbij ook follow-ups en vaccinaties deel uitmaken van 'medische noodhulp'. ${ }^{64}$ Vaccinaties tegen COVID-19 moeten op grond van deze uitleg worden aangeboden aan irreguliere migranten.

\subsubsection{Europees Sociaal Handvest (herzien): personele werkingssfeer}

De verdragsstaten hebben de personele werkingssfeer van het ESH (herzien) in de Bijlage ervan beperkt. Het overgrote deel van de ESH-rechten zijn alleen van toepassing op 'buitenlanders die onderdaan zijn van andere Overeenkomstsluitende Partijen en rechtmatig woonachtig zijn, dan wel geregeld werkzaam zijn op het grondgebied van de Overeenkomstsluitende Partij' (artikel 1 Bijlage ESH (herzien)). De beperking van de personele werkingssfeer dient volgens het ECSR echter niet zo te worden geïnterpreteerd dat het tot gevolg heeft dat irreguliere migranten bescherming van hun fundamentele rechten wordt onthouden, noch dat hun fundamentele rechten zoals het recht op leven of op fysieke integriteit of het recht op menselijke waardigheid worden geschonden. Het recht op medische bijstand is van zo'n fundamenteel belang voor het recht op leven en daarmee voor de menselijke waardigheid, dat het volgens het ECSR in strijd is met het ESH (herzien) als nationale regelgeving of praktijk het recht op medische bijstand onthoudt aan irreguliere migranten. ${ }^{65}$ Dit geldt temeer voor kinderen, die in een extra kwetsbare positie verkeren. Volgens het ECSR hebben ook irreguliere migranten recht op noodzakelijke sociale en geneeskundige bijstand en onderdak. Het voorkómen van een

\footnotetext{
${ }^{59}$ Art. 11 ESH (herzien).

${ }^{60}$ Art. 13 lid 1 ESH (herzien).

${ }^{61}$ ECSR 8 september 2004, 14/2003, JV 2005/339 m.nt. C.A. Groenendijk (FIDH/Frankrijk), par. 34. De klacht van FIDH betrof het feit dat irreguliere migranten in Frankrijk (inclusief kinderen) recht op medische bijstand hadden in geval van 'immediate threat to life' en alleen toegang tot het stelsel van medische bijstand na een periode van drie maanden. Ten aanzien van kinderen en jonge personen achtte het ECSR dit in strijd met art. 17 ESH (herzien) (recht van kinderen op jeugdige personen op sociale, juridische en economische bescherming).

${ }^{62}$ ECSR 3 december 2008, 46/2007, GJ 2009/84 m.nt. A.C. Hendriks (ERRC/Bulgarije).

${ }^{63}$ Annotator Hendriks leest de zaak ERRC/Bulgarije aldus dat de zorgplicht van de overheid verder gaat dan enkel medische noodhulp, A.C. Hendriks, annotatie bij: ERRC/Bulgarije (supra noot 62).

${ }^{64}$ Parliamentary Assembly, Human Rights of irregular migrants, Report Committee on Migration, Refugees and Population. Rapporteur: Mr Ed van Thijn, 4 May 2006, Doc. 10924, par. 57.

${ }^{65}$ FIDH/Frankrijk (supra noot 61), par. 31. Zie ook ECSR 12 februari 2008, 47/2008, NTM/NJCM-bull. 2010, m.nt. A. Buyse (DCI/Nederland), ECSR 23 oktober 2012, 69/2011, EHRC 2013/16 m.nt. G.J.W. Pulles (DCI/België), ECSR 1 juli 2014, 90/201, JV 2015/24, m.nt. C.H. Slingenberg (CEC/Nederland).
} 
aanzuigende werking is volgens het Comité onvoldoende rechtvaardiging om mensen basale levensbehoeften te onthouden. ${ }^{66}$

De menselijke waardigheid speelt aldus een belangrijke rol in de uitleg van de gelimiteerde personele werkingssfeer van het ESH (herzien) door het ECSR, evenals de uitleg van het ESH (herzien) in het licht van andere internationale verdragen, zoals het IVRK. De beperkte personele werking lijkt overigens in tegenspraak met Resolutie 1509 (2006), waarin de Parlementaire Vergadering van de Raad van Europa (Parlementary Assembly of the Council of Europe, PACE) als uitgangspunt neemt dat internationale mensenrechtenverdragen (inclusief sociale rechten) voor iedereen - ongeacht verblijfsstatus - gelden. ${ }^{67}$ Ondanks de aldus 'opgerekte' personele werking van het ESH (herzien), is de juridische betekenis van het ESH (herzien) voor de irreguliere migrant in ieder geval in Nederland vooralsnog beperkt. Dat komt doordat Nederlandse rechters (en politici) oordelen van het ECSR weliswaar als gezaghebbend, maar niet als juridisch bindend beschouwen. ${ }^{68}$

Het ESH (herzien) kent een discriminatiebepaling in deel V artikel E: een verschil in behandeling dat gegrond is op een objectieve en redelijke rechtvaardiging wordt niet als discriminerend beschouwd. Lidstaten mogen volgens het ECSR een onderscheid maken tussen mensen met of zonder verblijfsstatus, zolang de menselijke waardigheid, als fundamentele waarde in de kern van Europese mensenrechten wordt gerespecteerd. ${ }^{69}$ Het ECSR bevestigt daarmee haar lijn bij de uitleg van artikel 1 van de Bijlage ESH (herzien) over de personele werkingssfeer van het verdrag.

\subsubsection{Recht op zorg voor de gezondheid van irreguliere migranten}

De Europese Conventie voor de Wettelijke Status van Migrantenwerkers (1997) is alleen van toepassing op rechtmatig verblijvende migranten. ${ }^{70}$ Doel van de eerder genoemde Resolutie 1509 was het verhelderen van de minimumrechten van irreguliere migranten. De Resolutie definieert het minimumrecht op gezondheidszorg van irreguliere migranten als volgt: 'Emergency health care should be available to irregular migrants and states should seek to provide more holistic health care, taking into account, in particular, the specific needs of vulnerable groups such as children, disabled persons, pregnant women and the elderly'. ${ }^{71}$ Hierbij werd de lidstaten van de Raad van Europa dringend aanbevolen om het mensenrechtelijk instrumentarium dat irreguliere migranten beschermt te ondertekenen en te ratificeren, zoals het $\mathrm{VN}$-verdrag inzake de bescherming van de rechten van migrantenarbeiders en hun gezinnen. ${ }^{72}$

De Europese Commissie tegen Racisme en Intolerantie van de Raad van Europa beveelt de lidstaten aan om te verzekeren dat alle irreguliere migranten volledig beschermd zijn tegen

\footnotetext{
${ }^{66}$ CEC/Nederland (supra noot 65).

${ }^{67}$ Parliamentary Assembly 2006, Resolution 1509 (2006), Human rights of irregular migrants, art. 5.

${ }^{68}$ Hierover o.a. De Meij NJB 2015/542, zie ook CRvB 17 december 2014, ECLI:NL:CRVB:2014:4178 AB 2015/61, m.nt. C.W.C.A. Bruggeman.

${ }^{69}$ DCI/the Netherlands (supra noot 64).

${ }^{70}$ Raad van Europa, Europese Conventie voor de Wettelijke Status van Migrantenwerkers (1997). ETS 93.

${ }^{71}$ Parliamentary Assembly (supra noot 64), art. 13.2. Volgens de Parliamentary Assembly was het noodzakelijk om de minimumrechten te verduidelijken maar zou een juridisch instrument speciaal gewijd aan de rechten van irreguliere migranten waarschijnlijk geen steun krijgen van de lidstaten van de Raad van Europa.

${ }^{72}$ Parliamentary Assembly 2006 (supra noot 64).
} 
alle vormen van discriminatie en dat hun fundamentele mensenrechten zoals het recht op gezondheidszorg dienen te worden gerespecteerd. Het recht op gezondheidszorg dient formeel in nationale wetgeving te worden gegarandeerd, ook voor irreguliere migranten, inclusief 'emergency medical treatment and other forms of necessary health care'. ${ }^{73}$

\subsection{Het recht op zorg voor de gezondheid van kinderen}

\subsubsection{IVRK}

Kinderen en jongeren tot 18 jaar genieten additionele bescherming op grond van het internationale recht, supranationale en regionale verdragen.

Artikel 24 IVRK erkent het recht van het kind op de grootst mogelijke mate van gezondheid en op geneeskundige bijstand. Lidstaten dienen de toegang tot zorg van ieder kind te waarborgen. Artikel 3, eerste lid IVRK geeft aan dat bij alle maatregelen betreffende kinderen de belangen van het kind een eerste overweging dienen te vormen. Het belang van het kind heeft geen absolute voorrang boven andere belangen maar heeft wel een zwaarwegend karakter. ${ }^{74}$ Het recht van het kind op gezondheid (artikel 24 IVRK) en zijn gezondheidstoestand staan centraal bij de beoordeling van het belang van het kind. ${ }^{75}$ De gezondheid van het kind en de behandelingsmogelijkheden kunnen ook deel uitmaken van een beoordeling en bepaling van het belang van andere soorten belangrijke beslissingen (bijvoorbeeld het verlenen van een verblijfsvergunning op humanitaire gronden). ${ }^{76}$ Uit het discriminatieverbod van artikel 2 IVRK vloeit voort dat alle kinderen gelijk behandeld moeten worden. Van belang is ook het recht op ontwikkeling (artikel 6 IVRK). Dit recht dient holistisch te worden benaderd in het licht van alle andere kinderrechten, waaronder het recht op gezondheid. Rekening dient te worden gehouden met de kwetsbare situatie van een kind met een handicap (artikel 23).

Artikel 24 lid 1 IVRK bevat voor staten een positieve verplichting om kinderen te beschermen tegen fysieke en psychologische schade. ${ }^{77}$ Nederland is het enige land dat een voorbehoud heeft gemaakt bij artikel 26 IVRK waarin het recht van kinderen op sociale zekerheid is neergelegd.

Het EU-Handvest van de Grondrechten (Handvest) bepaalt dat kinderen recht hebben op de bescherming en de zorg die nodig zijn voor hun welzijn (artikel 24 lid 1) en dat de belangen van het kind bij alle handelingen met betrekking tot kinderen, ongeacht of deze worden verricht door overheidsinstanties of particuliere instellingen, de eerste overweging moeten vormen (artikel 25 lid 1).

Op grond van artikel 2 EVRM hebben staten de positieve verplichting om preventieve maatregelen te nemen tegen levensbedreigende gezondheidsrisico's waarvan zij op de hoogte

\footnotetext{
73 ECRI General Policy Recommendation No. 16 on Safeguarding irregularly present migrants from discrimination, Strasbourg, 10 mei 2016, onder 21.

${ }^{74}$ Committee on the Rights of the Children, General comment no. 14 (2013), On the right of the child to have his or her best interests taken as a primary consideration, art. 3, par. 1.

${ }^{75}$ General Comment No. 14 (supra noot 1), par. 77.

${ }^{76}$ General Comment No. 14 (supra noot 1), par. 78.

77 VN-Mensenrechtencomité 26 maart 2019, 2498/2014, RSV 2019/262, m.nt. P.E. Minderhoud (Abdoellaevna/Nederland).
} 
zijn of zouden moeten zijn. ${ }^{78}$ Daarnaast hebben staten positieve verplichtingen jegens kinderen die onder de zorgplicht van de overheid vallen. ${ }^{79}$

Volgens het ECSR hebben onrechtmatig verblijvende minderjarigen recht op gezondheidszorg die verder strekt dan medische noodhulp. Het recht op gezondheidszorg omvat tevens primaire en secundaire zorg en psychologische bijstand ${ }^{80}$ Toegang tot zorg staat in relatie tot opvangvoorzieningen van minderjarige kinderen. Gebrek aan opvangvoorzieningen kan zorgen voor drempels in de toegang. Toegang tot huisvesting is een belangrijke voorwaarde om oorzaken van gezondheidsproblemen weg te nemen. ${ }^{81}$

In september 2011 heeft het Comité van Ministers van de Raad van Europa Richtlijnen voor kindvriendelijke gezondheidszorg aangenomen. ${ }^{82}$ Volgens deze richtlijn moeten alle kinderen gelijke toegang hebben tot hoogwaardige gezondheidszorg. Dit omvat preventie, promotie, bescherming en dienstverlening met actieve betrokkenheid van kinderen. ${ }^{83}$ Er kan behoefte zijn aan specifieke gezondheidszorg voor meer kwetsbare kinderen zoals migrantenkinderen, vluchtelingen- en asielzoekerskinderen en niet-begeleide kinderen. ${ }^{84}$ De richtlijn stelt het belang van het kind voorop bij alle behandelingen met betrekking tot het kind. ${ }^{85}$

\subsubsection{Recht op gelijke zorg of op essentiële gezondheidszorg?}

Het weigeren van toegang tot gezondheidszorg vanwege irreguliere status is primair in strijd met het discriminatieverbod van artikel 2 IVRK. ${ }^{86}$ Søvig wijst op een op het eerste gezicht ogenschijnlijke tegenspraak in 'concluding observations' van het Kinderrechtencomité - dat toezicht houdt op de naleving van het VN-Kinderrechtenverdrag door Staten - ten aanzien van het recht op toegang tot de gezondheidszorg van irreguliere kinderen. In een aanbeveling aan Zweden beval het Comité aan om noodzakelijke stappen te ondernemen om te verzekeren dat alle kinderen - inclusief ongedocumenteerde kinderen - een recht op gezondheidszorg en gezondheidsvoorzieningen hebben onder dezelfde voorwaarden als kinderen die rechtmatig in het land verblijven. ${ }^{87}$ Aan Nederland echter luidde de aanbeveling om passende maatregelen te nemen om te verzekeren dat alle kinderen op het grondgebied toegang hebben tot essentiële gezondheidszorg. ${ }^{88}$ Dit zijn volgens Søvig twee verschillende gezichtspunten: een discriminatoire en een 'fundamentele mensenrechtenbenadering'. Alhoewel de eerste benadering volgens hem de voorkeur heeft, is het juridisch nog geen uitgemaakte zaak. Duidelijk is dat een irregulier kind meer beschermd dient te worden dan een volwassene, aldus

\footnotetext{
${ }^{78}$ Onder meer EHRM 23 maart 2010, ECLI:NL:XX:2010:BM6763 (Oyal/Turkije), EHRM 24 april 2012, Apll.nr. 19202/03 (Iliya Petrov/ Bulgarije) (beschikbaar in het Frans).

${ }^{79}$ EHRM 17 juli 2014, ECLI:NL:XX:2014:564 (Centre for Legal Resources on behalf of Valentin Câmpeanu/ Roemenië), EHRC 2014/212, m.nt. H. de Vylder.

${ }^{80}$ FIDH/Frankrijk (supra noot 61), par. 35-37 en DCI/ België (supra noot 65).

${ }^{81}$ DCI/België (supra noot 65), par. 116-118.

${ }^{82}$ Guidelines on child-friendly health care (Adopted by the Committee of Ministers on 21 September 2011 at the 1121 st meeting of the Ministers' Deputies).

${ }^{83}$ Art. D13.

${ }^{84}$ Art. D14.

${ }^{85}$ Art. E15.

${ }^{86}$ Søvig, EJHL 2011/1, p. 43-54.

${ }^{87}$ Kinderrechtencomité 26 juni 2009, CRC/C/SWE/CO/4 (2009), par. 61.

${ }^{88}$ Kinderrechtencomité 17 maart 2009, CRC/C/NLD/CO/3 (2009), par. 52.
} 
Søvig. ${ }^{89}$

Met betrekking tot preventieve gezondheidszorg merkt Flegar op dat het Kinderrechtencomité weliswaar heeft uitgesproken dat asielzoekerskinderen volledige toegang dienen te hebben tot preventieve gezondheidszorg, met speciale aandacht voor hun geestelijke gezondheid en sociale rehabilitatie, maar dat het Comité niet expliciet refereert aan ongedocumenteerde kinderen. ${ }^{90}$ Ongedocumenteerde kinderen zijn zelfs niet expliciet genoemd in de context van non-discriminatie, de juridische status is zelden genoemd als discriminatieverbod en er is geen specifieke General Comment hierover. Dit betekent volgens Flegar echter niet dat zij niet vallen onder 'all children', in het licht van doel en het IVRK. Ondanks het feit dat algemeen is aanvaard dat ongedocumenteerde kinderen onder de werkingssfeer van het IVRK vallen, is de juridische argumentatie volgens Flegar dun. ${ }^{91}$

Hiertegen kan worden ingebracht dat het Kinderrechtencomité expliciet heeft uitgesproken dat alle kinderen die betrokken zijn bij of direct te maken hebben met internationale migratie recht hebben op het genot van hun rechten, ongeacht leeftijd, geslacht, etnische of nationale afkomst en economische of documentatiestatus, in zowel vrijwillige als onvrijwillige migratiesituaties, al dan niet onder begeleiding, onderweg of op een andere manier geregeld, gedocumenteerd of zonder papieren of andere. ${ }^{92}$ Dit is ook erkend door de Raad van de Europese Unie, die heeft opgemerkt dat "het EU-Handvest van de Grondrechten en het Verdrag van de Verenigde Naties inzake de rechten van het kind bepalen dat kinderen als zodanig moeten worden behandeld, ongeacht hun migratiestatus, nationaliteit of achtergrond". ${ }^{93}$ Lidstaten worden opgeroepen om in de praktijk te waarborgen dat alle kinderen worden beschermd tegen discriminatie en dat ze gelijke kansen krijgen, zodat zij zich ten volle kunnen ontplooien. ${ }^{94}$ Ook het Europese Parlement heeft verklaard dat elk kind in de eerste plaats een kind is van wie de rechten zonder onderscheid moeten worden vervuld, ongeacht de etnische afkomst, de nationaliteit of de sociale, migratie- of verblijfsstatus van het kind. ${ }^{95}$

In het licht van het doel van het IVRK en de hierboven genoemde aanbevelingen op internationaal niveau is het mijns inziens gerechtvaardigd om te stellen dat irreguliere kinderen een gelijk recht op zorg hebben (de discriminatoire mensenrechtenbenadering dus). Ook de medische ethiek noopt tot deze uitleg, zoals al bleek in paragraaf 5.4.

\subsection{EVRM}

6.5.1 Relevantie voor het recht op zorg voor de gezondheid

\footnotetext{
${ }^{89}$ Søvig, EJHL 2011/1, p. 43-54.

${ }^{90}$ Flegar 2019, p. 355.

${ }^{91}$ Flegar 2019, p. 350.

${ }^{92}$ Committee on the Rights of the Child. Report of the 2012 Day of General Discussion on the rights of all children in the context of international migration, punt 13.

${ }^{93}$ Council conclusions on unaccompanied minors, 3018th Justice and Home Affairs Council, Luxembourg, 3 June 2010, par. c.

${ }^{94}$ Conclusions of the Council of the EU on the promotion and protection of the rights of the child, 17 December $2014(17016 / 14)$, par. 5 en 12.

${ }^{95}$ European Parliament resolution of 27 November 2014 on the 25 th anniversary of the UN Convention on the Rights of the Child (2014/2919(RSP)), Q.
} 
Het EVRM kent geen recht op (zorg voor de) gezondheid als zodanig, maar heeft in toenemende mate het recht op zorg voor de gezondheid en op sociale zekerheid en geneeskundige bijstand (in)direct beschermd. Het EHRM heeft op basis van het EVRM ook positieve verplichtingen voor de staat aangenomen. Uitspraken van het EHRM over de verplichtingen van verdragsstaten op het terrein van de gezondheidszorg, worden over het algemeen gebaseerd op het recht op leven (artikel 2 EVRM), het verbod op foltering en onmenselijke behandeling (artikel 3 EVRM) en het recht op privacy (artikel 8 EVRM). De reikwijdte van een positieve verplichting, inclusief gezondheid gerelateerde kwesties, hangt af van de omstandigheden van het individuele geval. ${ }^{96}$ Het EVRM garandeert geen recht op gratis medische zorg. ${ }^{97}$

\subsubsection{Artikel 2 EVRM}

Artikel 2 EVRM legt vergaande positieve verplichtingen op aan de overheid om het genot van het recht op leven optimaal te verzekeren. Het bevat de positieve materiële verplichting van de overheid om maatregelen te nemen om het leven te beschermen en de positieve procedurele verplichting om een effectieve procedure in te stellen indien het recht op leven geschonden is. ${ }^{98}$ Er dient een effectief onderzoek naar de doodsoorzaak van overledenen te worden verricht, vooral indien deze van zijn vrijheid is beroofd of bij verdachte omstandigheden rondom het overlijden. ${ }^{99}$

Een staat is op grond van artikel 2 EVRM verplicht om te zorgen voor adequate regelgeving op het terrein van de gezondheidszorg, inclusief het onderzoeken van wilsbekwaamheid bij het weigeren van een (levens)noodzakelijke behandeling. ${ }^{100}$ Het recht op leven houdt onder meer in dat autoriteiten zich naar vermogen dienen in te spannen om te voorkómen dat mensen vroegtijdig komen te overlijden. ${ }^{101}$ Volgens het EHRM kan het onthouden van noodzakelijke zorg aan een hulpbehoevende tot schending van artikel 2 EVRM leiden. Dit was het geval in de zaak Mehmet Şentürk \& Bekir Şentürk/Turkije waarin aan een zwangere vrouw medische hulp werd geweigerd omdat het gezin geen aanbetaling kon doen voor de kosten van de opname, terwijl er sprake was van een ernstige medische conditie van de patiënt. ${ }^{102}$ Volgens het EHRM hebben overheden de plicht om regelgeving aan te nemen die ziekenhuizen dwingt om maatregelen te nemen om het leven te beschermen. Ook dienen zij noodzakelijke maatregelen te nemen ter implementatie, toezicht en handhaving van een dergelijk kader. ${ }^{103}$ In Genç/Turkije ging het om een baby die overleed doordat hem geen enkele behandeling geboden werd. ${ }^{104}$ Volgens het Hof is sprake van schending van het recht op leven

\footnotetext{
${ }^{96} \mathrm{Zie}$ over het leerstuk van de positieve verplichtingen Gerards 2018.

${ }^{97}$ Onder meer EHRM 4 januari 2005, nr. 14462/03 (Pentiacova e.a./Moldavië).

${ }^{98}$ EHRM 4 mei 2000 (ontv.), Appl.nr. $45305 / 99$ (Powell/Verenigd Koninkrijk), EHRM 27 januari 2015, EHRC 2015/80, m.nt. B.C.A. Toebes (Genç/Turkije).

${ }^{99}$ EHRM 27 januari 2011, nr. 10907/04 (Iordanovi/Bulgarije).

${ }^{100}$ EHRM 5 december 2013, ECLI:NL:XX:2013:291, GJ 2014/5, m.nt. A.C. Hendriks (Arskaya/Oekrä̈ne). In deze zaak stelde het Hof niet alleen een procedurele schending (een niet-deugdelijk overlijdensonderzoek), maar ook een materiële schending van art. 2 EVRM (het ontbreken van passende regels voor het vaststellen van de besluitvaardigheid van patiënten met inbegrip van het vereiste informed consent) vast.

${ }^{101}$ Hendriks 2009, p. 619.

102 EHRM 9 april 2013, nr. 13423/09, EHRC 2013/142, m.nt. B.C.A. Toebes (Mehmet Şentürk \& Bekir Şentürk/Turkije).

${ }^{103}$ Mehmet Şentürk \& Bekir Şentürk/Turkije (supra noot 102), voortbordurend op Powell/VK (supra noot 98).

${ }^{104}$ EHRM 27 januari 2015, nr. 24109/07, EHRC 2015/80 m.nt. Toebes (Asiye Genç/Turkije).
} 
als adequate medische zorg structureel niet-beschikbaar is en de patiënt daardoor komt te overlijden. Alleen in uitzonderlijke gevallen zijn de autoriteiten verantwoordelijk. Daarvan is bijvoorbeeld sprake als het leven van een patiënt bewust in gevaar wordt gebracht door het weigeren van een levensreddende spoedbehandeling.

\subsubsection{Artikel 3 EVRM}

In zaken waarin wordt geklaagd over schending van artikel 3 EVRM, beoordeelt het EHRM of het 'minimum level of severity' is behaald. In het kader van personen in detentie heeft het EHRM een reeks uitspraken gedaan waarin sprake was van schending van het EVRM vanwege een gebrek aan medische zorg. ${ }^{105}$ Daarbij kan ook sprake zijn van aantasting van de waardigheid van een persoon. ${ }^{106}$ In V.D./Roemenië oordeelde het EHRM de weigering om een kunstgebit te verschaffen aan een gedetineerde die tijdens detentie zijn laatste tanden en kiezen had verloren, ernstig genoeg om het 'minimum level of severity' dat vereist is voor schending van artikel 3 EVRM, te overstijgen. ${ }^{107}$ Buiten detentie lijkt de ondergrens van artikel 3 aanzienlijk hoger te liggen. ${ }^{108}$ Zo achtte het Hof het onthouden van medische zorg aan een minderjarige zwangere in strijd met artikel 3 EVRM. ${ }^{109}$

Artikel 3 EVRM legt diverse positieve verplichtingen op aan de nationale autoriteiten ter voorkoming van foltering en ter waarborging van de menselijke behandeling van personen. ${ }^{110}$ Bij uitzetting van ernstig zieke vreemdelingen kan er sprake zijn van zodanig bijzondere omstandigheden dat er strijd komt met artikel 3 EVRM. ${ }^{111}$ Het EHRM legt de lat hiervoor hoog en verzachtte deze iets in Paposhvili waar het begrip 'zeer bijzondere omstandigheden' werd doorgetrokken naar 'zeer zieke mensen die, ook al zijn ze niet in direct levensgevaar, een reëel risico lopen om, wegens de afwezigheid van een toereikende behandeling of het ontbreken van toegang daartoe, zullen worden blootgesteld aan een snelle en onomkeerbare verslechtering van de staat van gezondheid die zal leiden tot een verlaging van de levensverwachting'. ${ }^{112}$ De achterliggende reden van de strenge maatstaf van het EHRM is gelegen in het voorkómen van aanzuigende werking. ${ }^{113}$ Deze aanzuigende werking is echter niet bewezen. ${ }^{114}$

\subsubsection{Artikel 8 EVRM}

In het kader van artikel 8 merkt het EHRM respect voor menselijke waardigheid en menselijke vrijheid aan als the 'very essence' van het EVRM. Al in 1985 oordeelde het Hof dat het in artikel 8 EVRM besloten liggende recht op respect voor het privéleven en gezinsleven van een

\footnotetext{
${ }^{105}$ EHRM 28 januari 1994, nr. 17549/90, (Hurtado/Zwitserland), par. 79.

${ }^{106}$ EHRM 3 mei 2007, nr. 2778/02 (Hüseyn Yildirim/Turkije).

${ }^{107}$ EHRM 16 februari 2010, 7078/02, ECHR 2010/48 m.nt. C.H. Slingenberg (V.D./Roemenië).

108 Zie ook C.H. Slingenberg, annotatie bij: V.D./Roemenië (supra noot 107).

${ }^{109}$ EHRM 30 oktober 2012, nr. 57375/08, EHRC 2013/15, m.nt. A.C. Hendriks (P. \& S./Polen).

${ }^{110}$ Hendriks 2015, p. 539.

111 EHRM 2 mei 1997, RV 1997/70 (D./VK (St. Kitts) en EHRM (Grote Kamer) 27 mei 2008, ECLI:NL:XX:2008:BD6647 (N./Verenigd Koninkrijk), GJ 2008/99, m.nt. A.C. Hendriks.

112 EHRM 13 december 2016, 41738/10, JV 2017/22, m.nt. B.E.P. Myer (Paposhvili). Zie uitvoeriger par. 7.6.3.

113 Onder anderen P. de Albuquerque, gedeeltelijke dissenting opinion bij Lopes de Sousa Fernandes/Portugal (supra noot 3). Zie par. 7.6.4 van dit proefschrift.

${ }^{114}$ Zie par. 7.6.4 van dit proefschrift.
} 
persoon mede de fysieke en psychische integriteit van die persoon omvat. ${ }^{115}$ Het artikel beoogt niet alleen de staten tot onthouding van inmenging in het privéleven te dwingen, maar kan onder omstandigheden ook voor het recht op eerbiediging van het privéleven inherente positieve verplichtingen meebrengen die noodzakelijk zijn voor een effectieve waarborging ervan. Daarbij hebben kinderen en andere kwetsbare personen in het bijzonder recht op bescherming. Het EHRM heeft meer malen geoordeeld dat artikel 8 EVRM ook relevant is in zaken die betrekking hebben op de besteding van publieke middelen in de sociaaleconomische sfeer. ${ }^{116}$ Daarbij is wel van belang dat aan de Staat een extra ruime 'margin of appreciation' toekomt, terwijl het EHRM bij de bepaling van de bescherming die betrokkenen genieten onder het EVRM belang toekent aan de al dan niet legale status van het verblijf van betrokkene. ${ }^{117}$

In het arrest Domenech Pardo/Spanje overwoog het EHRM dat, alhoewel het EVRM als zodanig geen recht op uitkering waarborgt, de weigering om een sociale uitkering toe te kennen in bepaalde omstandigheden in strijd kan zijn met artikel 8 EVRM, bijvoorbeeld indien ten gevolge van die weigering de normale ontwikkeling van het familie- en gezinsleven van de minderjarige onmogelijk wordt gemaakt. ${ }^{118}$

\subsubsection{Personele werkingssfeer en discriminatieverbod}

Lidstaten hebben de opdracht om de EVRM-rechten te verzekeren aan 'een ieder' die zich onder hun jurisdictie bevinden (artikel 1 EVRM). Hierbij is irrelevant of degene die zich op het EVRM beroept de nationaliteit van de betreffende staat heeft. ${ }^{119}$ Onder 'een ieder' vallen ook irreguliere migranten. In de meeste Europese landen heeft het enkele decennia geduurd om te accepteren dat 'everyone' in het EVRM ook daadwerkelijk 'iedereen' betekent, en dat vreemdelingen beschermd zijn door de meeste bepalingen van de mensenrechten instrumenten. ${ }^{120}$

Het EVRM kent een discriminatieverbod in artikel 14, maar dit artikel kan enkel ingeroepen worden in combinatie met andere verdragsrechten en -vrijheden. De lijst met verboden discriminatiegronden bevat wel 'nationale afkomst' maar niet 'nationaliteit'. Deze begrippen zijn overigens geen synoniemen: de nationaliteit van een persoon kan een andere zijn dan 'nationale afkomst'. Door opname van de grond 'andere status' is de lijst echter als nietlimitatief te beschouwen. Protocol 12 bevat wel een zelfstandig discriminatieverbod voor het genot van elk in de wet neergelegd recht. De discriminatiegronden zijn dezelfde als artikel 14 EVRM. ${ }^{121}$

Van discriminatie in de zin van artikel 14 EVRM en artikel 1 van het Twaalfde Protocol van het EVRM is sprake indien een objectieve en redelijke rechtvaardiging voor ongelijke behandeling ontbreekt. Dit is volgens vaste jurisprudentie van het EHRM het geval als het

\footnotetext{
${ }^{115}$ EHRM 26 maart 1985, ECLI:NL:XX:1985:AC8813, NJ 1985, 525, m.nt. E.A. Alkema (X.\&Y./Nederland), par. 22.

${ }^{116}$ Zo bracht het EHRM in de zaak Niedzwiecki/Duitsland de toekenning van kinderbijslag onder de werkingssfeer van art. 8 EVRM, EHRM 25 oktober 2005, nr. 58453/00, EHRC 2005/121 (Niedzwiecki/Duitsland).

${ }^{117}$ N./Verenigd Koninkrijk (supra noot 111).

${ }^{118}$ EHRM 3 mei 2001, nr. 55996/00 (Domenech Pardo/Spanje).

${ }^{119}$ Van Dijk e.a. 1961, p. 11, onder verwijzing naar Yearbook IV (1961), p. 116 (138-140).

${ }^{120}$ Bogusz et al 2004, p. xix.

${ }^{121}$ Protocol nr. 12 bij het EVRM.
} 
onderscheid in behandeling geen legitiem doel dient of indien de daartoe gebezigde middelen niet in redelijke en proportionele verhouding tot dat doel staan. ${ }^{122}$ De staat heeft daarbij een grote mate van beleidsvrijheid ('margin of appreciation'). ${ }^{123}$ De reikwijdte van deze beleidsvrijheid hangt onder meer af van factoren als sociaaleconomisch karakter van het beleidsdomein en de gronden waarop onderscheid wordt gemaakt. ${ }^{124}$ Volgens vaste jurisprudentie van het EHRM is het staten toegestaan om een onderscheid te maken tussen verschillende categorieën vreemdelingen die op hun grondgebied verblijven en in het beperken van toegang tot bepaalde categorieën vreemdelingen zoals irreguliere migranten tot 'resource-hungry public services' zoals gezondheidszorg, omdat zij niet aan de financiering hiervan hebben bijgedragen. ${ }^{125}$ Een verdragsstaat moet haar migratiepolitiek uitvoeren op een wijze die in overeenstemming is met de rechten van de mens. ${ }^{126}$

Alleen die vormen van onderscheid zijn verboden die gebaseerd zijn op identificeerbare, objectieve en persoonlijke kenmerken, of 'status', die individuen of groepen onderscheiden van anderen. Onderscheid op grond van nationaliteit mag alleen worden gemaakt als daarvoor 'zeer zwaarwichtige redenen' ('very weighty reasons') bestaan. Het EHRM duidt 'nationaliteit' namelijk aan als zogenoemd verdacht criterium. ${ }^{127}$ Uitsluitingen van sociale voorzieningen zoals zorgverzekeringen worden vaak niet op basis van nationaliteit, maar op grond van verblijfsstatus gemaakt. Verblijfsstatus op zichzelf is door het Hof niet als 'verdacht' aangemerkt, maar kan wel onder 'andere status' vallen, ook al is het een door de wet gegeven status en geen inherent en onveranderlijk kenmerk van een persoon. ${ }^{128} \mathrm{Bij}$ de toets spelen zowel de individuele omstandigheden van de klager als het belang van het in geding zijnde fundamentele recht een rol. Bij een recht dat directe bescherming geniet onder het EVRM zal eerder sprake zijn van discriminatie. ${ }^{129}$ Bij de individuele omstandigheden neemt het EHRM bijvoorbeeld in aanmerking of de klager al dan niet vrijwillig heeft gekozen voor zijn of haar status en of klager 'met opzet' naar het betreffende land is gekomen om te profiteren van sociale voorzieningen. ${ }^{130}$

\subsubsection{Overige instrumenten Raad van Europa}

De aanbeveling van het Comité van Ministers over mensen in situaties van extreme ontbering verdient nog vermelding. Volgens de aanbeveling is het recht op de voldoening van basisbehoeften, waaronder basale medische zorg, universeel en afdwingbaar. Onder basisbehoeften

\footnotetext{
${ }^{122}$ De staat moet zwaarwichtige redenen hebben om rechten verschillend toe te passen, bijvoorbeeld ten aanzien van het recht op een eerlijk proces (art. 6 EVRM), EHRM 10 maart 2009, nr. 45413/07 (Anakomba Yula/ België). ${ }^{123}$ EHRM 27 september 2009, 56328/07 (Bah/Verenigd Koninkrijk).

${ }^{124}$ Gerards 2011, p. 1019.

${ }^{125}$ EHRM 21 juni 2011, nr. 5335/05 (Ponomaryovi/Bulgarije), par. 54. In deze zaak achtte het Hof het betalen van collegegeld voor secundair onderwijs door irreguliere kinderen in strijd met art. 14 EVRM of art. 1 van Protocol 12.

${ }^{126}$ EHRM 10 maart 2011, nr. 2700/10, EHRC 2011, 84, m.nt. J.H. Gerards (Kiyutin/Rusland). In deze zaak achtte het Hof het vereiste van een hiv-negatieve status voor de toekenning van een verblijfsvergunning in strijd met art. 14 EVRM in samenhang met art. 8 EVRM.

${ }^{127}$ EHRM 16 september 1996, nr. 17371/90 (Gaygusuz/Oostenrijk). Nationaliteit is gekwalificeerd als 'verdachte' grond waarbij de 'very weighty reasons' test geldt.

${ }^{128}$ Bah/United Kingdom (supra noot 123).

${ }^{129}$ Art. 1 van het Protocol bevat een zelfstandig discriminatieverbod, terwijl het discriminatieverbod van art. 14 EVRM gecombineerd dient te worden met een ander door het Verdrag beschermde recht.

${ }^{130}$ De eerste omstandigheid speelde een rol in Bah/United Kingdom (supra noot 122), par. 47, de tweede in Ponomaryovi/Bulgarije (supra noot 125), par. 61.
} 
vallen het minimum recht op voedsel, kleding, huisvesting en basale medische zorg. Het recht op basisbehoeften moet open staan voor alle burgers en vreemdelingen, ongeacht hun positie of status. ${ }^{131}$

Het in 1997 tot stand gekomen Biogeneeskundeverdrag bevat het recht op gelijke toegang tot gezondheidsvoorzieningen ('Biogeneeskundeverdrag'). ${ }^{132}$ Het bepaalt dat lidstaten de nodige maatregelen nemen teneinde zorg te dragen voor gelijke toegang tot gezondheidszorg van passende kwaliteit (artikel 3). Nederland heeft dit verdrag niet geratificeerd, onder meer vanwege de 'verstrekkende en mogelijk ingrijpende implicaties' van het Verdrag zoals de verwachte mogelijke rechtstreekse werking van bovengenoemd artikel, dat volgens de RvS verder gaat dan een minimumpakket van noodzakelijke medische zorg. In beginsel zou deze verplichting inhouden dat elke medische voorziening voor eenieder gelijkelijk beschikbaar moet zijn. De RvS betwijfelde of de Nederlandse wetgeving en de feitelijk situatie hieraan voldoen, onder meer door te verwijzen naar de Koppelingswet op grond waarvan irreguliere migranten uitgesloten zijn van sociale voorzieningen, maar nog wel recht hebben op 'medisch noodzakelijke zorg'. ${ }^{133}$ Ondanks het feit dat Nederland het Verdrag niet heeft geratificeerd, kan het via verwijzing van het EHRM naar het Biogeneeskundeverdrag toch van betekenis zijn, dus ook voor irreguliere migranten. ${ }^{134}$

\subsection{EU-recht}

\subsubsection{Recht op zorg voor de gezondheid en volksgezondheid}

Voor het recht op zorg voor de gezondheid van de irreguliere migrant is in de eerste plaats het primaire EU-recht van belang. Het VWEU stipuleert dat bij de vaststelling en uitvoering van het beleid en de maatregelen van de Unie een hoog niveau van bescherming van de menselijke gezondheid wordt gewaarborgd. De Unie heeft de algemene bevoegdheid om complementair aan nationaal beleid, stimuleringsmaatregelen te nemen ter bescherming en verbetering van de volksgezondheid. ${ }^{135}$ Het Handvest kent een aantal met het EVRM corresponderende rechten, maar ook een aantal niet als zodanig in het EVRM voorkomende rechten, zoals het zelfstandige recht op de menselijke waardigheid. ${ }^{136}$ Het Handvest is uitsluitend van toepassing bij het tenuitvoerleggen van EU-recht door EU instellingen en lidstaten. ${ }^{137}$ Daarmee is de werkingssfeer van het Handvest beperkt. Het Handvest bevat het recht op sociale zekerheidsvoorzieningen en het recht op toegang tot preventieve gezondheidszorg en op medische verzorging 'onder de door de nationale wetgeving en praktijken gestelde voorwaarden'. ${ }^{138}$

\footnotetext{
${ }^{131}$ Committee of Ministers, Recommendation No. R (2000) 3 of the Committee of Ministers to member states on the Right to the Satisfaction of Basic Material Needs of Persons in Situations of Extreme Hardship.

${ }^{132}$ Verdrag tot bescherming van de rechten van de mens en de waardigheid van het menselijk wezen met betrekking tot de toepassing van de biologie en de geneeskunde (Trb. 1997, 113).

${ }^{133}$ RvS 11 april 2000, W13.00.0053/III/K, Bijvoegsel Stcrt. 2004, 47. Met Dute ben ik het eens dat het bezwaar van de RvS op dit punt niet steekhoudend is, aangezien de gelijke toegang tot zorg een algemeen aanvaard uitgangspunt is, Dute 2015, TvGR 2015/6, p. 394-402.

${ }^{134}$ Vergelijk Dute 2015, TvGR 2015/6, p. 394-402.

135 Art. 168 VWEU.

136 Art. 1 Handvest.

${ }^{137}$ Art. 41 Handvest.

${ }^{138}$ Artt. 34 en 35 Handvest.
} 


\subsubsection{Personele werkingssfeer en discriminatieverbod}

Het VWEU bevat een discriminatieverbod op grond van nationaliteit (artikel 18). Dit discriminatieverbod staat er niet aan in de weg dat een gastlidstaat een economisch niet-actieve EUburger die niet voldoet aan de voorwaarden van zijn recht op vrij verkeer, uitsluit van sociale bijstand. ${ }^{139}$ De Europese Rassenrichtlijn verbiedt discriminatie op grond van ras en etniciteit en ziet weliswaar mede op sociale zekerheid en gezondheidszorg, maar sluit verschillen in behandeling op basis van nationaliteit expliciet uit. De richtlijn staat het verschillen in behandeling gebaseerd op nationaliteit niet in de weg. Het doet geen afbreuk aan voorwaarden voor toegang en verblijf van onderdanen van derde landen en staatlozen tot c.q. op het grondgebied van de lidstaten, noch aan enige behandeling die het gevolg is van de juridische status van de betrokken onderdanen van derde landen en staatlozen. ${ }^{140}$ Op basis van het VWEU zijn het de EU-burgers die - in het kader van het vrije verkeer - gelijk behandeld dienen te worden.

De meeste grondrechten uit het Handvest gelden voor 'eenieder', dus ongeacht nationaliteit of verblijfsstatus. Zo niet, dan wordt dit expliciet in het desbetreffende grondrecht vermeld. ${ }^{141}$ Dit is het geval bij het recht op sociale zekerheidsvoorzieningen. ${ }^{142}$ Het vereiste van legaal verblijf geldt niet ten aanzien van het recht van 'eenieder' op toegang tot preventieve gezondheidszorg en medische verzorging. ${ }^{143}$ Wel geldt de beperking dat dit recht bestaat 'onder de door de nationale wetgevingen en praktijken gestelde voorwaarden'.

Daarnaast is elke discriminatie op grond van (onder meer) nationaliteit verboden (artikel 21 lid 2 Handvest). Gelet op artikel 53 Handvest, zouden deze bepalingen niet restrictiever mogen worden geïnterpreteerd dan de uitleg van het EHRM zoals hierboven uiteengezet.

\subsubsection{Relevant secundair EU-recht}

Was het beleid van de EU eerst vooral gericht op het voorkómen van irreguliere migratie en het uitzetten van irreguliere migranten, sinds de inwerkingtreding van het Verdrag van Lissabon (2009) is sprake van de ontwikkeling van een gemeenschappelijk migratiebeleid waarbij meer aandacht is voor het verbeteren van de mensenrechten van de migranten binnen de EU. ${ }^{144}$

De TRi is van toepassing op derdelanders die niet-rechtmatig ('illegaal') in een lidstaat verblijven. Asielzoekers vallen niet onder het toepassingsbereik van de TRi. ${ }^{145}$ De ratio van de TRi is om op basis van gemeenschappelijke normen een doeltreffend verwijderings- en terugkeerbeleid te ontwikkelen, zodat mensen op een humane manier, met volledige eerbiediging van hun grondrechten en waardigheid, teruggezonden kunnen worden. ${ }^{146}$ Voor

\footnotetext{
${ }^{139}$ HvJ EU 11 november 2014, C-333/13 (Dano) ECLI:EU:C:2014:2358.

140 Art. 3 lid 2 Richtlijn 2000/43/EG van de Raad van 29 juni 2000 houdende toepassing van het beginsel van gelijke behandeling van personen ongeacht ras of etnische afstamming.

${ }^{141}$ Bijvoorbeeld artikelen 39, 40 en 46.

142 Art. 34 lid 2 Handvest.

143 Art. 35 Handvest.

${ }^{144}$ Zie over deze ontwikkeling Desmond, Human Rights Law Review 2016/16, p. 247-272.

${ }^{145}$ Art. 9 TRi. Zie ook par. 2.2.3.2.

${ }^{146}$ Considerans 2 TRi.
} 
irreguliere migranten die nog niet kunnen worden uitgezet dient te worden voorzien in elementaire levensbehoeften. ${ }^{147}$ Voor zover vreemdelingen niet kunnen vertrekken, dient dringende medische zorg te worden verstrekt en essentiële behandeling van ziekte te worden uitgevoerd. ${ }^{148} \mathrm{Er}$ wordt rekening gehouden met de speciale behoeften van kwetsbare personen. ${ }^{149}$ Volgens de TRi zijn dit (niet-begeleide) minderjarigen, personen met een handicap, bejaarden, zwangere vrouwen, alleenstaande ouders met minderjarige kinderen en personen die gefolterd of verkracht zijn of andere ernstige vormen van psychisch, fysiek of seksueel geweld hebben ondergaan. ${ }^{150}$ De bepaling over dringende medische zorg is een grondrecht en de toegang tot dit recht mag niet afhangen van de betaling van geldelijke vergoedingen. ${ }^{151}$

\subsubsection{Aanbevelingen Europees Parlement}

In veel lidstaten is gelijke toegang tot gezondheidszorg niet gegarandeerd, wettelijk of in de praktijk, aldus het Europees Parlement (EP). Het EP dringt er dan ook bij de lidstaten op aan om te waarborgen dat irreguliere migranten recht hebben op en gelijke toegang verkrijgen tot gezondheidszorg, en verzoekt de lidstaten aan de hand van een op gemeenschappelijk principes te baseren definitie de haalbaarheid te onderzoeken van ondersteuning van de elementaire componenten van de gezondheidszorg voor irreguliere migranten, met specifieke waarborgen voor kinderen en vrouwen. ${ }^{152}$

\subsection{Menselijke waardigheid}

De menselijke waardigheid neemt een centrale positie in binnen het mensenrechten-raamwerk. De preambule van het VN-Handvest noemt de 'waardigheid van de mens' als één van de grondslagen en na te streven beginselen van de VN. De UVRM is het eerste document dat de menselijke waardigheid als grondslag van de daarin opgesomde rechten aanvoert. Het verwijst ook expliciet naar menselijke waardigheid in artikel 22 betreffende het recht op sociale zekerheid en economische, sociale en culturele rechten die onmisbaar zijn voor waardigheid. De grondslag van menselijke waardigheid wordt herhaald in andere VN-verdragen, waaronder het IVBPR, het IVESCR, het VN-Vrouwenverdrag en het IVRK. Op regionaal niveau bevatten het ESH en het Biogeneeskundeverdrag verwijzingen naar menselijke waardigheid. Het EVRM verwijst niet expliciet naar de notie van menselijke waardigheid. ${ }^{153}$ Het EHRM beschouwt de menselijke waardigheid als deel van de kern van het EVRM. ${ }^{154}$ Het Handvest stelt in artikel 1: 'Human dignity is inviolable. It must be respected and protected'.

Naast een grondslag biedt het principe richting bij de interpretatie van specifieke grondrechten. Het EHRM hanteert menselijke waardigheid als een van de criteria om te bepalen

\footnotetext{
${ }^{147}$ HvJ EU 18 december 2014, C-562/13 (Adbida).

148 Art. 14 sub b TRi.

${ }^{149}$ Art. 14 sub d TRi.

${ }^{150}$ Art. 3 lid 9 TRi.

${ }^{151}$ Europese Commissie, bijlage Terugkeerhandboek, onder 13.

${ }^{152}$ European Parliament resolution of 8 March 2011 on reducing health inequalities in the EU (2010/2089(INI)), onder 5.

${ }^{153}$ Zie ook Bronsword 2014 en Brems \& Vrielink 2010.

${ }^{154}$ Zie bijvoorbeeld EHRM, 28 september 2015, EHRC 2015/236 m.nt S. Smet (Bouyid t. België).
} 
of een behandeling voldoende ernstig is om onder het verbod van artikel 3 EVRM te laten vallen. We hebben gezien dat het ECSR de menselijke waardigheid als grondslag gebruikte bij de interpretatie van de personele werking van het ESH (herzien). Het concept van menselijke waardigheid is multi-interpretabel en kan op verschillende wijzen worden ingevuld. Het volgende hoofdstuk gaat verder in op de relevantie van menselijke waardigheid in het kader van artikel 3 EVRM.

\subsection{Conclusie}

Het recht op zorg voor de gezondheid is een fundamenteel mensenrecht dat progressief gerealiseerd dient te worden en dat een aantal minimumverplichtingen voor de staat bevat, waaronder het verzekeren van het recht op toegang tot gezondheidsdiensten zonder discriminatie, met name voor kwetsbare en gemarginaliseerde groepen.

In de afgelopen decennia heeft een evolutie plaatsgevonden ten aanzien van de vraag of het bereik van het recht op zorg voor de gezondheid tevens van toepassing is op irreguliere migranten. Volgens de VN-mensenrechteninstrumenten, is het recht op zorg voor de gezondheid van de irreguliere migrant equivalent aan het recht op zorg voor de gezondheid voor ingezetenen. Kern van dit recht is het recht op toegang tot adequate gezondheidszorgvoorzieningen, goederen en diensten zonder discriminatie, het recht op spoed en primaire medische zorg en essentiële medicijnen. Deze kern is niet onderhevig aan de progressieve realisatie of aan financiële beperkingen. Beperkingen van het recht op zorg voor de gezondheid van irreguliere migranten mogen niet leiden tot aantasting van deze kern.

Het recht op zorg voor de gezondheid wordt tevens beschermd door het recht op leven, dat het recht op een waardig leven includeert. Daarnaast noopt het Duurzame Ontwikkelingsdoel UHC staten tot een transitie naar betaalbare en voor iedereen toegankelijke kwalitatief hoogstaande gezondheidszorg. De instrumenten van de Raad van Europa zijn in vergelijking met de VN-mensenrechteninstrumenten restrictiever in hun toepassingsbereik. De beperkte personele reikwijdte van het ESH (herzien) houdt echter geen stand als fundamentele rechten of de menselijke waardigheid in het geding zijn. Vrouwen hebben recht op gratis preen postnatale zorg. Kinderen hebben een gelijk recht op gezondheidszorg. Bij het onthouden van medisch noodzakelijke zorg en bij uitzetting van ernstig zieke vreemdelingen kan het EVRM een rol spelen. De TRi tenslotte verplicht EU-lidstaten tot het bieden van dringend medische zorg en essentiële behandeling van ziekten.

De minimumrechten die voortvloeien uit de verdragen garanderen echter nog geen afdwingbare individuele aanspraken op zorg. Doordat er geen concrete normen zijn, zijn deze niet tot lastig af te dwingen bij de rechter.

Staten beperken aanspraken op sociale voorzieningen vaak op grond van verblijfsstatus. Dit onderscheid is in beginsel toegestaan. In het domein van sociale zekerheid - en daaronder valt het recht op gezondheidszorg - geldt een ruime 'margin of appreciation'. Toch blijkt uit de jurisprudentie van het EHRM dat onderscheid naar verblijfsstatus een discriminatiegrond kan opleveren, afhankelijk van de individuele omstandigheden en de aard van de in het geding zijnde rechten. Maar daarvoor zijn wel zwaarwegende redenen nodig. 


\title{
Hoofdstuk 7 Uitzetting van de (ernstig) zieke vreemdeling
}

\author{
"Refugees, migrants and foreign nationals are the \\ first to be singled out in a dehumanised and selfish \\ society. Their situation is even worse when they are \\ seriously ill. They become pariahs whom \\ Governments want to get rid of as quickly as \\ possible. It is a sad coincidence that in the present \\ case the Grand Chamber decided, on the World \\ Day of the Sick, to abandon these women and men \\ to a certain, early and painful death alone and far \\ away. I cannot desert those sons of a lesser God \\ who, on their forced path to death, have no one to \\ plead for them." \\ Bron: Dissenting opinion van rechter Pinto de \\ Albuquerque in S.J./België.
}

\subsection{Inleiding}

Dit hoofdstuk gaat over de uitzetting van de ernstig zieke vreemdeling en de toegankelijkheid van zorg in het land van herkomst. Het EHRM heeft in de uitzettingsjurisprudentie principiële uitgangspunten geformuleerd voor de vraag of onrechtmatig verblijvende vreemdelingen met een gezondheidsprobleem die vertrekplichtig zijn, kunnen blijven profiteren van de gezondheidszorg van het uitzettende land. Daarmee is dit leerstuk te scharen onder het leerstuk van het recht op gezondheidszorg van de onrechtmatig verblijvende vreemdeling.

Het leerstuk geeft tevens nadere verdieping aan jurisprudentie van het EHRM over artikel 3 EVRM en sluit daarom goed aan op het vorige hoofdstuk. Het ziet - evenals het vorige hoofdstuk - op beantwoording van deelvraag 1: Welke aanspraken op gezondheidszorg heeft de onrechtmatig verblijvende vreemdeling in Nederland ten principale? Het ziet specifiek op de vraag op welke wijze wordt getoetst of de zorg voor de gezondheid in den vreemde bij uitzetting wordt gewaarborgd.

Het hoofdstuk beoogt niet het leerstuk van uitzetting van de zieke vreemdeling in al zijn merites te behandelen, maar onderzoekt het leerstuk in het licht van de vraag welke principiële aanspraak op zorg kan worden gemaakt bij uitzetting. De Nederlandse praktijk en jurisprudentie worden in hoofdlijnen besproken waarbij de verenigbaarheid met de EHRM-jurisprudentie aan bod komt.

Eerst zal een schets worden gegeven van het nationaalrechtelijk wettelijk kader rondom de uitzetting van zieke vreemdelingen (uitstel van vertrek van artikel $64 \mathrm{Vw}$ en een medische 
artikel 3-EVRM beoordeling). Het overkoepelende grondbeginsel van de artikel 3-EVRM beoordeling is het beginsel van non-refoulement. Dan volgt een bespreking van de inhoud en reikwijdte van artikel 3 EVRM. Vervolgens volgt een analyse van de geleidelijke evolutie in de jurisprudentie van zowel het EHRM als navolgend het HvJ EU met betrekking tot de uitzetting van (ernstig) zieke vreemdelingen. Tot slot komen het Nederlandse beleid en de jurisprudentie inzake uitzetting aan bod.

\subsection{Problematiek}

De beslissing om zieke vreemdelingen terug te sturen naar hun land van herkomst is in de eerste plaats een nationale aangelegenheid. Er bestaat geen internationale verdragsverplichting om zieke vreemdelingen uitsluitend op medische gronden een verblijfsvergunning te verstrekken. Indien uitzetting naar het land van herkomst echter tot onmenselijke omstandigheden voor de vreemdeling zou leiden, kan artikel 3 van het Europees Verdrag tot bescherming van de rechten van de mens (EVRM) een rol spelen. Het in dit artikel besloten beginsel van non-refoulement biedt op indirecte wijze bescherming aan de (dood)zieke vreemdeling.

In het algemeen zullen zieke vreemdelingen, die gedwongen worden terug te keren naar hun land van herkomst, problemen krijgen met de toegang tot (adequate) medische zorg. Door de sociale en economische verschillen en de vooruitgang van de wetenschap kan het niveau van de beschikbare behandelingen aanzienlijk verschillen met dat van de uitzettende staat. ${ }^{1}$ Medicatie kan bijvoorbeeld niet beschikbaar zijn of is te duur voor de betreffende vreemdeling. Soms kan een abrupte stopzetting van een medische behandeling, die in het uitwijzende land is begonnen, leiden tot een ernstige verslechtering van de gezondheidstoestand van de vreemdeling. Maar ook kan sprake zijn van een bedreiging voor de gezondheid van vreemdelingen in het land van herkomst, zoals besnijdenis van meisjes en vrouwen.

\subsection{Nationaal wettelijk kader: artikel 64 Vw}

Medische aandoeningen zijn op zich geen reden om voor asielbescherming in Nederland in aanmerking te komen. Het is algemeen aanvaard dat dit buiten de vluchtelingendefinitie valt. ${ }^{2}$ Alleen als er sprake is van uitzonderlijke omstandigheden en dwingende redenen van humanitaire aard kunnen zieke vreemdelingen in aanmerking komen voor asiel. ${ }^{3}$

Een vreemdeling die niet aan de vertrekplicht voldoet, kan worden uitgezet (paragraaf 2.2.3.2). Bij ernstige medische problematiek kan de IND in twee gevallen uitstel van vertrek verlenen op grond van artikel $64 \mathrm{Vw}$. Het eerste geval is als het gelet op de gezondheidstoestand van de vreemdeling of die van een van zijn gezinsleden niet verantwoord is om te reizen. Het tweede geval is als er een reëel risico bestaat op schending van artikel 3 EVRM om medische redenen. ${ }^{4}$ Als het verzoek wordt ingewilligd, wordt uitstel van vertrek verleend voor de verwachte duur van de medische behandeling of voor een periode van maximaal één jaar. $\mathrm{Na}$ afloop van deze periode ontstaat van rechtswege (wederom) de rechtsplicht om Nederland

\footnotetext{
${ }^{1}$ EHRM (Grote Kamer) 27 mei 2008, ECLI:NL:XX:2008:BD6647 (N./Verenigd Koninkrijk), GJ 2008/99, m.nt. A.C. Hendriks, par. 44.

${ }^{2}$ Den Heijer 2019, p. 5.

${ }^{3}$ Paragraaf C2/3.3 Vreemdelingencirculaire 2000.

${ }^{4}$ Paragraaf A3/7 Vreemdelingencirculaire 2000.
} 
binnen vier weken te verlaten en kan de vreemdeling alsnog worden uitgezet. $\mathrm{Na}$ een jaar onafgebroken verblijf op grond van artikel $64 \mathrm{Vw}$ kan de vreemdeling een reguliere vergunning verband houdend met medische behandeling aanvragen. Een succesvol beroep op artikel 64 schort het vertrek op. De vreemdeling krijgt tijdelijk rechtmatig verblijf in Nederland totdat de medische omstandigheden zijn gewijzigd. Hij valt dan onder de RZA.

Advies over de medische aspecten wordt verleend door het Bureau Medische Advisering (BMA), in opdracht van de IND. De medisch adviseur doet onderzoek naar de gezondheidstoestand en de behandeling van de vreemdeling op basis van schriftelijke informatie van diens behandelaar. Het medisch advies dient te voldoen aan de zorgvuldigheidseisen waaraan de tuchtrechter medische adviezen en rapporten in het algemeen toetst. $^{5}$

De beoordeling van de vraag naar een medische noodsituatie op korte termijn ziet uitsluitend op beoordeling van de situatie bij het uitblijven van de behandeling en niet op de gevolgen bij of na terugkeer naar het land van herkomst/bestemming.

In artikel 3-EVRM-gevallen gaat het om ernstiger medische situaties dan bij de vraag naar de medische noodsituatie op de korte termijn. Het gaat hier immers om de vraag of er sprake is van strijd met het verbod op onmenselijke of vernederende behandeling bij het uitblijven van de medische behandeling van de vreemdeling. Dit verbod komt in meerdere internationale instrumenten tot uitdrukking.

\subsection{Het beginsel van non-refoulement}

Het beginsel van non-refoulement vormt de essentie van het internationale vluchtelingenrecht. ${ }^{6}$ Het garandeert dat niemand wordt teruggestuurd naar een land waar hij of zij te maken krijgt met foltering, wrede, onmenselijke of vernederende behandeling of bestraffing en andere onherstelbare schade. Artikel 33 lid 1 VN-Vluchtelingenverdrag ${ }^{7}$ bepaalt:

“Geen der Verdragsluitende Staten zal, op welke wijze ook, een vluchteling uitzetten of terugleiden naar de grenzen van een grondgebied waar zijn leven of vrijheid bedreigd zou worden op grond van zijn ras, godsdienst, nationaliteit, het behoren tot een bepaalde sociale groep of zijn politieke overtuiging."

Zolang een asielaanvraag nog niet is afgewezen, kan een vluchteling een beroep doen op dit artikel.

Het verbod op refoulement is daarnaast expliciet opgenomen in het VN-Verdrag tegen Foltering. ${ }^{8}$ Artikel 3 lid 1 luidt: "Geen enkele Staat die partij is bij dit verdrag, mag een persoon

\footnotetext{
${ }^{5}$ Deze tuchtrechtelijk verankerde zorgvuldigheidscriteria zijn: 1. Het rapport vermeldt de feiten, omstandigheden en bevindingen waarop het berust; 2 . Het rapport geeft blijk van een geschikte methode van onderzoek om de voorgelegde vraagstelling te beantwoorden; 3 . In het rapport wordt op inzichtelijke en consistente wijze uiteengezet op welke gronden de conclusies van het rapport steunen; 4. Het rapport vermeldt de bronnen waarop het berust, daaronder begrepen de gebruikelijke literatuur en de geconsulteerde personen; 5. De rapporteur blijft binnen de grenzen van zijn deskundigheid. Zie CTG 30 januari 2014, TvGR 2014, m.nt. J.C.J. Dute, p. 241-248.

${ }^{6}$ Zie ook OHCHR Discussion paper, Expulsions of aliens in international human rights law, Geneva, September 2006.

${ }^{7}$ Verdrag betreffende de status van vluchtelingen, Genève, 28-07-1951.

${ }^{8}$ Verdrag tegen foltering en andere wrede, onmenselijke en onterende behandeling of bestraffing, New York, 1012-1984.
} 
uitzetten of terugzenden naar of uitleveren aan een andere Staat wanneer er gegronde redenen zijn om aan te nemen dat hij of zij daar gevaar zou lopen te worden onderworpen aan foltering". Het beginsel is van toepassing op iedereen, ongeacht status, dus ook op alle migranten. Het VNComité tegen Foltering (Committe Against Torture, CAT) heeft sinds 1994 in veel gevallen schending van artikel 3 in uitzettingszaken aangenomen. ${ }^{9}$ Zo heeft het geoordeeld dat uitzetting van een vrouwelijke Guinese vluchteling in strijd was met artikel 3 omdat zij een te groot risico liep om tegen haar wil te worden besneden bij uitzetting naar Guinee. ${ }^{10}$ Het IVBPR kent geen specifieke bepaling die het beginsel van non-refoulement bevat. Jurisprudentie van het VNMensenrechtencomité over uitzetting is gebaseerd op artikel 7 IVBPR, dat bepaalt:

"Niemand mag worden onderworpen aan folteringen, of aan wrede, onmenselijke of vernederende behandeling of bestraffing. In het bijzonder mag niemand, zonder zijn in vrijheid gegeven toestemming, worden onderworpen aan medische of wetenschappelijke experimenten."

Volgens het VN-Mensenrechtencomité ligt het beginsel van non-refoulement in dit artikel besloten. ${ }^{11}$

Evenals het IVBPR kent het VN-Kinderrechtenverdrag een folterverbod (artikel 37), maar geen beginsel van non-refoulement. Het VN-Kinderrechtencomité heeft in het kader van de omgang met alleenstaande kinderen die niet in hun eigen land verblijven gesteld dat zij niet mogen worden uitgezet als er gegronde redenen zijn om aan te nemen dat er een reëel risico bestaat dat het kind onherstelbare schade wordt toegebracht. Bij de beoordeling van dat risico kunnen de gevolgen van een gebrek aan gezondheidsvoorzieningen een rol spelen. ${ }^{12}$

Het EVRM bevat evenmin een expliciet verbod op refoulement. In medische uitzettingszaken kan een beroep worden gedaan op artikel 3 EVRM, dat als volgt luidt:

"Niemand mag worden onderworpen aan foltering of aan onmenselijke of vernederende behandeling of bestraffing."

Volgens de rechtspraak van het EHRM kan het lijden dat voortvloeit uit een natuurlijk voorkomende ziekte, lichamelijk of geestelijk, onder artikel 3 vallen, wanneer dit lijden wordt of dreigt te worden verergerd door een behandeling, ongeacht of deze voortvloeit uit omstandigheden van detentie, uitzetting of andere maatregelen, waarvoor de autoriteiten verantwoordelijk kunnen worden gesteld. ${ }^{13}$ tegenstelling tot het EVRM, heeft het Handvest het beginsel van non-refoulement opgenomen in artikel 19, lid 2:

\footnotetext{
${ }^{9}$ Voor het eerst in CAT 27 april 1994, 13/1993 (Mutombo/Zwitserland).

${ }^{10}$ CAT 20 november 2015, 613/2014 (F.B./Nederland). Zie ook Hathaway \& Foster 2014, p. 214-216.

${ }^{11}$ CCPR General Comment No. 20, 10 maart 1992, par. 9.

${ }^{12}$ CRC General Comment No. 6 (2005), 1 september 2005, CRC/GC/2005/6, par, 27.

13 EHRM 29 april 2002, ECLI:NL:XX:2002:AP0678, NTM/NJCM-bull. 2002, p. 910, m.nt. E. Myer (Pretty/Verenigd Koninkrijk).
} 
"Niemand mag worden verwijderd of uitgezet naar, dan wel uitgeleverd aan een staat waar een ernstig risico bestaat dat hij aan de doodstraf, aan folteringen of aan andere onmenselijke of vernederende behandelingen of bestraffingen wordt onderworpen".

Zoals blijkt uit bovenstaand overzicht, is het beginsel van non-refoulement in diverse internationale verdragen verankerd. Voor het leerstuk van medische uitzettingszaken is vooral artikel 3 EVRM van belang, omdat er inmiddels rijke jurisprudentie van het EHRM over dit leerstuk bestaat. ${ }^{14}$ Daarnaast speelt mee dat EVRM-bepalingen volgens vaste jurisprudentie rechtstreekse werking hebben in de nationale rechtsorde van de lidstaten wanneer de bepalingen zich hiertoe lenen. Individuen kunnen naleving hiervan afdwingen en een beroep doen bij (uiteindelijk) het EHRM.

\subsection{Artikel 3 EVRM}

\subsubsection{Inleiding}

Zoals gezegd kan het risico op onmenselijke of vernederende behandeling niet alleen ontstaan door directe schadeveroorzakende handelingen, maar ook door ernstige ontberingen van sociaaleconomische rechten zoals het recht op gezondheidszorg. In de jurisprudentie van het Hof heeft het toepassingsgebied van artikel 3 EVRM zich geleidelijk uitgebreid van de vraag of de vreemdeling, indien hij naar zijn land van herkomst werd teruggestuurd, het risico liep om opzettelijk te worden onderworpen aan foltering of onmenselijke of vernederende behandeling of bestraffing door overheidsinstanties of niet-statelijke organen in dat land, tot overwegingen betreffende de lichamelijke of geestelijke gezondheid van een persoon. Deze paragraaf behandelt aard en inhoud van artikel 3 EVRM en licht toe op welke wijze het EHRM in het algemeen aan dit artikel toetst.

\subsubsection{Absoluut karakter}

In artikel 3 EVRM is een van de fundamentele waarden van democratische samenlevingen vastgelegd. ${ }^{15}$ Het bevat een absolute garantie van de rechten die het beschermt. ${ }^{16}$ Het doel van artikel 3 is het beschermen van de lichamelijke integriteit en de menselijke waardigheid.

Artikel 3 EVRM bevat een niet-derogeerbaar recht: staten mogen niet van dit recht afwijken in tijden van oorlog of andere openbare noodsituaties. Door het absolute karakter van het recht is er volgens het EHRM geen ruimte voor de 'margin of appreciation' doctrine. ${ }^{17} \mathrm{De}$ garanties van artikel 3 EVRM gelden ongeacht de verwerpelijke aard van het gedrag van de betrokken persoon. ${ }^{18}$ Evenmin makt het Hof - vanwege het absolute karakter - onderscheid tussen de behandeling die rechtstreeks door een ondertekende staat wordt toegepast en een

\footnotetext{
${ }^{14}$ Den Heijer 2019, p. 5.

${ }^{15}$ EHRM 2 mei 1997, ECL:NL:XX:1997:AB8007, NJ 1998, 582, RV 1997/70 (D./Verenigd Koninkrijk), par. 47. Dit arrest is ook wel bekend onder de naam St Kitts (zie hierna par. 7.6.1).

${ }^{16}$ Harris, O’Boyle \& Warbrick 2014, p. 235.

${ }^{17}$ EHRM, 28 februari 2008, ECLI:NL:XX:2008:BC6246 (Saadi/ Italië). Het ging in deze zaak om uitzetting van een terroristische vreemdeling. Het Hof kon niet instemmen met het argument van de regering van het Verenigd Koninkrijk dat de bescherming tegen het risico op mishandeling door een andere staat moet worden afgewogen tegen de belangen van de gemeenschap in zijn geheel.

${ }^{18}$ Saadi/Italië (supra noot 17).
} 
behandeling die door de autoriteiten van een andere staat zou kunnen worden toegepast. ${ }^{19}$ Dit geldt ook als het risico op onmenselijke behandeling stamt van factoren in het ontvangende land die op zichzelf geen inbreuk maken op artikel 3 EVRM. ${ }^{20}$ Dat is het geval in medische zaken, waar het gaat om het ontbreken van adequate medische zorg in het ontvangende land.

Het absolute karakter van artikel 3 EVRM wordt door sommigen niettemin gerelativeerd omdat de notie van absolute rechten de beoordeling van subjectieve factoren omvat. ${ }^{21}$ Met Greer kan het recht als nagenoeg absoluut en niet strikt absoluut worden beschouwd. ${ }^{22}$ Ook in medische uitzettingszaken kan - zoals we zullen zien - de door dit artikel geboden bescherming ondanks het absolute karakter in theorie worden ondermijnd als andere dwingende belangen worden ingeroepen. ${ }^{23}$ Het absolute karakter van artikel 3 is in medische uitzettingszaken afgekalfd door de belangen van de uitzettende staat, die de bevoegdheid heeft om irreguliere migranten uit te zetten. ${ }^{24}$ Het EVRM biedt in deze zaken niet de bescherming aan ernstig zieke irreguliere migranten zoals het dat zou behoren te doen. ${ }^{25}$

\subsubsection{Minimumniveau van ernst}

Het is vaste jurisprudentie van het EHRM dat mishandeling ('ill-treatment') een minimumniveau van ernst dient te bereiken ('must attain a minimum level of severity') om onder het bereik van artikel 3 EVRM te vallen. ${ }^{26}$ De beoordeling van dit minimum hangt af van de omstandigheden van het geval, zoals de aard en context van de behandeling, de wijze en de methode van uitvoering, de duur, de fysieke of mentale gevolgen en, in sommige gevallen, het geslacht, de leeftijd en de gezondheidstoestand van het slachtoffer. ${ }^{27}$ Deze factoren zijn ook van belang voor het onderscheid tussen de drie elementen.

\subsubsection{De drie elementen van artikel 3 EVRM: onderscheid}

Artikel 3 EVRM noemt drie elementen: foltering, onmenselijke behandeling en vernederende behandeling. Terwijl het VN-Verdrag tegen Foltering een duidelijke definitie van foltering bevat (artikel 1) laat artikel 3 EVRM de definitie van de drie elementen open. ${ }^{28}$ De inkleuring ervan in het individuele geval is overgelaten aan de omstandigheden van het geval.

\footnotetext{
${ }^{19}$ Saadi/ Italië (supra noot 17).

${ }^{20}$ D./Verenigd Koninkrijk (supra noot 15), par. 49.

${ }^{21}$ Addo \& Grief, European Journal of International Law 1998/9, p. 510-524.

${ }^{22}$ Greer, Human Rights Law Review 2015/1, p. 101-137.

23 In niet-medische uitzettingszaken wordt het absolute karakter van het beginsel van non-refoulement gehandhaafd. Zie bijvoorbeeld de zaak van Hirsi Jamaa e.a./Italië. In deze zaak ging het om elf Somaliërs en dertien Eritreeërs die vluchtten van Libië naar Italië. Voordat zij Italië bereikten werden zij onderschept door de Italiaanse kustwacht en teruggebracht naar Tripoli. Het EHRM achtte schending van art. 3 EVRM aanwezig doordat zij een reëel risico liepen als irreguliere migranten op mishandeling door de Libische autoriteiten en het risico liepen te worden uitgezet naar Somalië of Eritrea, alwaar zij het risico op foltering en detentie onder onmenselijke omstandigheden zouden lopen, EHRM 23 februari 2012, nr. 27765/09, A\&MR 2012, Nr. 3 - 141 , m.nt. M. den Heijer (Hirsi Jamaa e.a../Italië).

${ }^{24}$ Zie Stoyanova, International Journal of Refugee Law 2017/4, p. 615.

${ }^{25}$ In gelijke zin Kahn, Columbia Journal of European Law 2019/2, p. 222-252.

${ }^{26}$ Zie onder meer EHRM 26 oktober 2000, nr. 30210/96 (Kudla/Polen), par. 91, Pretty/Verenigd Koninkrijk (supra noot 13).

${ }^{27}$ Kudla/Polen (supra noot 26), par. 91.

${ }^{28}$ In eerdere versies van het artikel werden vormen van foltering genoemd, zie voor de ontwerpgeschiedenis Roscam Abbing 1979, 57-59.
} 
Voor 'foltering' is volgens jurisprudentie van het EHRM een bepaalde opzettelijke onmenselijke handeling vereist, die zeer ernstig en wreed lijden veroorzaakt. ${ }^{29}$

Voor 'onmenselijke behandeling' geldt dat er een bepaald minimumniveau (een onderdrempel) van ernst dient te zijn bereikt die gepaard gaat met daadwerkelijk lichamelijk letsel of intens lichamelijk of geestelijk lijden. ${ }^{30}$ Opzet of een oogmerk is niet vereist. Het begrip 'onmenselijke behandeling' is in theorie minder ontwikkeld dan de andere elementen. ${ }^{31}$ Het is open voor subjectieve interpretatie en toepassing. De drempel voor onmenselijke behandeling ligt hoger dan de drempel voor vernederende behandeling. ${ }^{32}$ Bij 'vernederende behandeling' gaat het om vernedering of krenking. Van de behandeling of bestraffing van een individu kan worden gezegd dat het vernederend is als het hem ten overstaan van anderen grof vernedert of hem ertoe aanzet om tegen zijn wil of geweten in te grijpen. ${ }^{33}$ Het uitblijven of weigeren van medische zorg kan als vernederend worden aangemerkt, aangezien dit bezorgdheid, stress of lijden kan veroorzaken. ${ }^{34}$ In Pretty/Verenigd Koninkrijk oordeelde het EHRM als volgt:

"Where treatment humiliates or debases an individual showing a lack of respect for, or diminishing, his or her human dignity or arouses feelings of fear, anguish or inferiority capable of breaking an individual's moral and physical resistance, it may be characterised as degrading and also fall within the prohibition of Article 3 (...).35

Een duidelijke afbakening tussen de verschillende handelingen genoemd in artikel 3 bestaat echter niet. Het gaat namelijk steeds om gradaties van vernedering. Dit stelde de Europese Commissie voor de Rechten van de Mens in de Greek case:

"It is plain that there may be treatment to which all these descriptions apply, for all torture must be inhuman and degrading treatment, and inhuman treatment also degrading". ${ }^{36}$

Hoewel van elkaar te onderscheiden - al dan niet terecht - hebben alle elementen gemeen dat de menselijke waardigheid in het geding is. ${ }^{37}$

7.5.5 De drie elementen van artikel 3 EVRM in medische gevallen

Het EHRM heeft vastgesteld dat de categorisering van mishandeling over de jaren heen kan wijzigen. Dit volgt uit het dynamische karakter van het EVRM. Zo is over de jaren heen het 'minimum level of severity' al gereduceerd. ${ }^{38}$ Dit hangt samen met het feit dat het EHRM

\footnotetext{
${ }^{29}$ EHRM 18 januari 1978, nr. 5310/71 (Ierland/Verenigd Koninkrijk).

${ }^{30}$ Pretty/Verenigd Koninkrijk (supra noot 13).

${ }^{31}$ Evans and Morgan, 1998, p. 93 en Vorhaus, Common Law World Review 2002, afl. 4, p. 374-399.

${ }^{32}$ Vorhaus 2002, p. 396. Murtagh stelt de volgende opvatting van onmenselijke behandeling voor: in de context van de mensenrechten is onmenselijke behandeling een behandeling die in hoge mate vernederend is. De schending van de fundamentele waardigheid is omvangrijker en ernstiger dan wanneer wordt beweerd dat de behandeling slechts een vernederende behandeling is, Murtagh, Criminal Law and Philosophy 2012/1, p. 21-30.

${ }^{33}$ Greek Case (1969), YECHR 1, p 186.

${ }^{34} \mathrm{Vgl}$. Toolkit European Convention on Human Rights, Verbod op foltering en onmenselijke of vernederende behandeling (artikel 3), coe.int.

${ }^{35}$ Pretty/Verenigd Koninkrijk (supra noot 13), par. 52.

${ }^{36}$ The Greek case (1969), Yearbook 1, p 186. De voormalige Europese Commissie voor de Rechten van de Mens deed een vooronderzoek in een nieuwe zaak voordat deze mogelijk naar het EHRM werd gestuurd

${ }^{37}$ Murtagh, Criminal Law and Philosophy 2012/1, p. 21-30.

${ }^{38}$ EHRM 28 juli 1999, nr. 25803/94, (Selmouni/Frankrijk), par. 101.
} 
hogere eisen stelt aan staten op basis van artikel 3 EVRM. ${ }^{39}$ Deze constatering is van belang voor medische gevallen. Dit type zaken wordt - alhoewel niet expliciet - geschaard onder de categorie 'onmenselijke behandeling'. Dit zou in de toekomst mogelijk kunnen veranderen vanwege het genoemde dynamische karakter van het EVRM.

\subsection{Jurisprudentie EHRM over uitzetting van (dood)zieke vreemdelingen}

Na deze inleiding over artikel 3 EVRM volgt hieronder een bespreking van de jurisprudentie van het EHRM over medische uitzettingszaken. De bespreking is onderverdeeld in drie 'tijdperken': van de bekende zaak St Kitts, waarin het Hof het 'bijna-dood' criterium formuleerde, langs de zaak S.J/België, waarbij het Hof ruimte bood voor andere 'zeer uitzonderlijke omstandigheden', tot de zaak Paposhvili, waarin het Hof nader specificeerde wat onder deze zeer uitzonderlijke omstandigheden kan worden verstaan.

\subsubsection{Van St Kitts tot N./Verenigd Koninkrijk}

Al in 1994 verklaarde de Europese Commissie voor de Rechten van de Mens ${ }^{40}$ in Tanko/ Finland - in welk geval een Ghanese asielzoeker met een oogziekte aanvoerde dat hij het risico liep blind te worden als hij naar Ghana moest terugkeren - dat dit "niet uitsluit dat een gebrek aan goede medische zorg in een geval waarin iemand aan een ernstige ziekte lijdt, in bepaalde omstandigheden kan neerkomen op een behandeling die in strijd is met artikel 3 EVRM". Er werd echter geen schending van artikel 3 vastgesteld, onder meer omdat er geen bewijs was dat Tanko zijn medicatie in Ghana niet kon krijgen. ${ }^{41}$

In D./Verenigd Koninkrijk (bekend als de zaak St Kitts) oordeelde het EHRM voor het eerst - en tot de zaak Paposhvili voorlopig voor het laatst - dat uitzetting in strijd met artikel 3 zou zijn, rekening houdend met de medische toestand van de vreemdeling. ${ }^{42}$ In deze zaak bevond de verzoeker zich in een vergevorderd stadium van aids, hij was reeds terminaal. Het ontvangende land (St Kitts) was echter niet in staat om hem de behandeling te geven die hij nodig had. Een abrupte terugtrekking van de zorgfaciliteiten in de staat van onrechtmatig verblijf (waar de vreemdeling hiv had opgelopen), in combinatie met het voorspelbare gebrek aan adequate faciliteiten en aan enige vorm van morele of sociale steun in St Kitts, zou de dood van de verzoeker bespoedigen en hem blootstellen aan acuut geestelijk en lichamelijk lijden. Gezien deze zeer uitzonderlijke omstandigheden, rekening houdend met de kritieke fase waarin de dodelijke ziekte van de verzoeker zich bevond en met de dwingende humanitaire overwegingen die in het geding waren, zou de uitvoering van het besluit om de vreemdeling naar St Kitts te verwijderen volgens het Hof neerkomen op een onmenselijke behandeling door de uitwijzende staat en dus in strijd met artikel 3 EVRM. Het Hof onderstreepte hierbij het absolute karakter van artikel 3 EVRM. ${ }^{43}$ Niet het feit dat er in het ontvangende land een gebrek

\footnotetext{
${ }^{39}$ Harris, O’Boyle \& Warbrick 2014, p. 237.

${ }^{40}$ De voormalige Europese Commissie voor de Rechten van de Mens deed vooronderzoek in een nieuwe zaak voordat deze mogelijk naar het EHRM werd gestuurd.

${ }^{41}$ EHRM 19 mei 1994, nr. 23634/94 (Tanko/ Finland).

${ }^{42}$ D./Verenigd Koninkrijk (supra noot 15).

${ }^{43}$ D./Verenigd Koninkrijk (supra noot 15), par. 49.
} 
aan gezondheidszorg was, noch de uitzetting zelf was in strijd met artikel 3 EVRM, maar de gevolgen van het besluit tot uitvoering van de verwijdering:

"In view of these exceptional circumstances and bearing in mind the critical stage now reached in the applicant's fatal illness, the implementation of the decision to remove him to St Kitts would amount to inhuman treatment by the respondent State in violation of Article 3" ${ }^{44}$

Het EHRM formuleerde in deze zaak een algemeen uitgangspunt waar het in latere zaken telkens aan refereerde:

"Against this background the Court emphasises that aliens who $[\ldots]$ are subject to expulsion cannot in principle claim any entitlement to remain in the territory of a Contracting State in order to continue to benefit from medical, social or other forms of assistance provided by the expelling State $[\ldots] .{ }^{{ }^{45}}$

In de zaak St Kitts werd een stevige basis gelegd voor de latere jurisprudentie van het Hof: alleen in zeer uitzonderlijke omstandigheden kon er volgens het Hof sprake zijn van schending van artikel 3 om dwingende humanitaire redenen. ${ }^{46}$ In de daaropvolgende medische uitzettingszaken heeft het Hof nimmer een schending van artikel 3 vastgesteld. Bij het onderzoek naar mogelijke schending van artikel 3 nam het Hof telkens de drie volgende elementen in aanmerking: ${ }^{47}$ 1. gezondheidstoestand van de persoon; 2 . de zorgvoorzieningen in het land van herkomst en het voorspelbare gebrek aan adequate voorzieningen; en 3. morele of sociale steun in het ontvangende land.

Ad 1 Gezondheidstoestand van de persoon

Er kan een onderscheid worden gemaakt tussen hiv/aids en andere ziekten. Bij hiv moest de irreguliere migrant in een vergevorderd of terminaal stadium van de ziekte verkeren. Als de ziekte zich niet in een terminaal of vergevorderd stadium bevond en medische behandeling nog mogelijk was en er sprake was van steun van de familie, was er geen sprake van een inbreuk op artikel 3 EVRM. Verzoeken van hiv-patiënten werden bijvoorbeeld niet ontvankelijk bevonden in de zaken Francisco J. Arcila Henao/Nederland en Amegnigan/Nederland, onder meer omdat de ziekte van de verzoeker niet in een vergevorderd of terminaal stadium was gekomen. ${ }^{48}$

De beschouwing van de gezondheidstoestand beperkte zich niet tot levensbedreigende ziekten. Zoals uit de jurisprudentie blijkt, wordt ook rekening gehouden met andere ziekten, zoals de posttraumatische stressstoornis (PTSS) en de langdurige psychische schizofrenie. Traumatisering is op zichzelf geen belemmering voor het terugsturen van een persoon naar het land van herkomst. Maar in Bensaid/Verenigd Koninkrijk oordeelde het Hof dat de mogelijke

\footnotetext{
${ }^{44}$ D./Verenigd Koninkrijk (supra noot 15), par. 53.

${ }^{45}$ D./Verenigd Koninkrijk (supra noot 15), par. 54.

${ }^{46}$ In paragraaf 54 kwalificeert het EHRM de situatie van D. als 'very exceptional', D./Verenigd Koninkrijk (supra noot 15 ).

${ }^{47}$ Derckx, EJHL 2006/4, p. 313-319.

48 EHRM 24 juni 2003, nr. 13669/03, NJCM-Bulletin 2003, p. 1015, m.nt. E. Myer (Francisco J. Arcila Henao/Nederland), EHRM 25 november 2004, nr. 26629/04, NTM/NJCM-bull. 2006, p. 206, m.nt. G. Lodder (Amegnigan/Nederland).
} 
ernstige gevolgen van de abrupte stopzetting van de psychiatrische behandeling in principe binnen de werkingssfeer van artikel 3 kunnen vallen. ${ }^{49}$

Het hebben van het syndroom van Down werd door het Hof niet gelijkgesteld aan het laatste stadium van een fatale ziekte en viel daarom niet onder de hoge drempel van artikel 3 EVRM. ${ }^{50}$

\section{Ad 2 De zorgvoorzieningen}

Het volgende punt dat het Hof onderzoekt is in hoeverre de aanvrager in het land van herkomst een passende medische behandeling kan krijgen. Het Hof houdt er rekening mee of er werkelijk gezondheidszorg beschikbaar is, afgezien van het gebrek aan geld of ziektekostenverzekering en afgezien van praktische belemmeringen om het ziekenhuis te bereiken. In de reeds genoemde zaak Bensaid/Verenigd Koninkrijk leed de aanvrager aan schizofrenie. Het dichtstbijzijnde ziekenhuis voor behandeling lag $80 \mathrm{~km}$ van het dorp waar zijn familie woonde. In dat deel van Algerije was er geweld en actief terrorisme. Het Hof achtte de moeilijkheid om naar het ziekenhuis te reizen en de gevolgen van deze factoren voor de gezondheid van de klager speculatief. Volgens het Hof stond de aanvrager in Algerije medische behandeling ter beschikking. Het feit dat de omstandigheden van verzoeker in Algerije minder gunstig zijn dan die in het Verenigd Koninkrijk, achtte het Hof niet beslissend uit het oogpunt van artikel 3 EVRM. Zelfs als hij in het Verenigd Koninkrijk zou blijven, liep hij het risico van een terugval, aangezien zijn ziekte van lange duur was en continu beheer vergde. ${ }^{51}$

Ook is niet het niveau van de zorg doorslaggevend, maar de mogelijkheid van behandeling in het algemeen, zoals blijkt uit de zaak Salkic e.a./Zweden, waar de aanvrager en zijn gezin aan PTSS leden. ${ }^{52}$ De omstandigheid dat de situatie van verzoeker in het land van herkomst minder gunstig zou zijn dan de situatie in Zweden, achtte het Hof niet als doorslaggevend in de zin van artikel 3 EVRM. ${ }^{53}$

\section{Ad 3 Ontbreken van morele of sociale steun}

Het feit dat de aanvrager een gezin heeft in het land van herkomst speelt ook een rol bij de rechtvaardiging van de verwijdering. Dit ongeacht de leeftijd van de gezinsleden of de vraag of zij financiële steun kunnen verlenen. Op grond van de jurisprudentie kan worden gesteld dat het Hof er gemakkelijk van uitgaat dat er in het land van herkomst sprake is van een vorm van morele of sociale steun. In Amegnigan/Nederland bijvoorbeeld moest de aanvrager, die aan hiv/aids leed, terug naar Togo: In deze zaak leek alleen al het feit dat de moeder en een jongere broer in Togo woonden, voldoende voor het Hof om aan te nemen dat er sprake was van gezinsondersteuning. ${ }^{54}$

\footnotetext{
49 EHRM 6 februari 2001, nr. 30240/96, EHRC 2001/25, JV 2001/103 (Bensaid/Verenigd Koninkrijk). In Nasimi/Zweden beweerde de aanvrager dat hij geestelijk getraumatiseerd was door ervaringen in Iran, maar zijn bewering was niet gestaafd, EHRM 16 maart 2004, nr. 38865/02 (Nasimi/Zweden).

${ }^{50}$ EHRM 27 september 2005, nr. 17416/05 (Hukic/Zweden).

${ }^{51}$ Bensaid/Verenigd Koninkrijk (supra noot 49), par. 38. Het Hof achtte art. 8 EVRM evenmin geschonden.

${ }^{52}$ EHRM 29 juni 2004, nr. 7702/04 (Salkic e.a./Zweden).

${ }^{53}$ Salkic e.a./Zweden (supra noot 52).

${ }^{54}$ Amegnigan/the Netherlands (supra noot 48).
} 


\title{
7.6.2 Van N./Verenigd Koninkrijk tot Paposhvili
}

Zoals gezegd, moest in zaken waarin de verzoeker leed aan hiv/aids de ziekte een gevorderde of terminale toestand bereiken, wat alleen het geval was in de zaak N./Verenigd Koninkrijk. ${ }^{55}$ In deze zaak stelde verzoekster, die hiv-positief was, dat het gebrek aan toegang tot de noodzakelijke medische behandeling in het ontvangende land Oeganda een schending van artikel 3 zou betekenen. Haar toestand was gestabiliseerd na de behandeling met antiretrovirale middelen en frequente monitoring en ze zou stabiel zijn gebleven met de basisbehandeling. In Oeganda zou ze echter al snel deze basismedicatie missen, waardoor haar gezondheidstoestand snel achteruit zou gaan met de dood tot gevolg.

Het EHRM (de Grote Kamer) vatte de algemene principes samen die in de zaak St Kitts ('zeer uitzonderlijke gevallen') en de daaropvolgende jurisprudentie waren geformuleerd:

\begin{abstract}
"Aliens who are subject to expulsion cannot in principle claim any entitlement to remain in the territory of a Contracting State in order to continue to benefit from medical, social or other forms of assistance and services provided by the expelling State. The fact that the applicant's circumstances, including his life expectancy, would be significantly reduced if he were to be removed from the Contracting State is not sufficient in itself to give rise to breach of Article 3. The decision to remove an alien who is suffering from a serious mental or physical illness to a country where the facilities for the treatment of that illness are inferior to those available in the Contracting State may raise an issue under Article 3, but only in a very exceptional case, where the humanitarian grounds against the removal are compelling. In the D. v. the United Kingdom case the very exceptional circumstances were that the applicant was critically ill and appeared to be close to death, could not be guaranteed any nursing or medical care in his country of origin and had no family there willing or able to care for him or provide him with even a basic level of food, shelter or social support." 56
\end{abstract}

Het Hof sloot niet uit dat er - in aanvulling op situaties zoals in de zaak St Kitts, waar de dood dreigde - 'andere zeer uitzonderlijke omstandigheden' ('other very exceptional circumstances') denkbaar zijn waarbij de humanitaire overwegingen even dwingend zijn. ${ }^{57}$ De Grote Kamer gaf echter geen nadere invulling aan deze 'zeer uitzonderlijke omstandigheden'. Dat deed het pas in het arrest Paposhvili. In de zaak N./Verenigd Koninkrijk stelde het Hof geen schending van artikel 3 EVRM vast. Door het gebrek aan medicatie overleed verzoekster N binnen een paar maanden na uitzetting naar haar thuisland. ${ }^{58}$

In de zaak N./Verenigd Koninkrijk rechtvaardigde de Grote Kamer het handhaven van de hoge drempel, die het sinds de zaak St Kitts hanteerde, met het argument dat de vermeende toekomstige schade niet het gevolg zou zijn van het opzettelijke handelen of nalaten van de overheid of van niet-overheidsinstanties, maar van een natuurlijk voorkomende ziekte en het gebrek aan voldoende middelen om deze in het ontvangende land aan te pakken. ${ }^{59}$ Hiermee tornde het Hof aan het absolute karakter van artikel 3 EVRM. Hendriks wees er in zijn annotatie op dat bij de vraag of artikel 3 EVRM wordt geschonden niet beslissend zou moeten zijn of de

\footnotetext{
${ }^{55}$ N./Verenigd Koninkrijk, (supra noot 1).

${ }^{56}$ N./Verenigd Koninkrijk (supra noot 1), par. 42.

${ }^{57}$ N./ Verenigd Koninkrijk (supra noot 1), par. 43.

${ }^{58}$ Izambert, HIV AIDS Policy Law Rev. 2010/1, p. 57-58.

${ }^{59}$ N./Verenigd Koninkrijk (supra noot 1), par. 43.
} 
gevaren afkomstig zijn van de overheid zelf of dat zij inherent zijn aan een ziekte. Tevens achtte hij het onbegrijpelijk dat het Hof niet toetste aan artikel 8 EVRM, terwijl dit tevens het recht op fysieke en morele integriteit van een persoon omvat. ${ }^{60}$

Daarnaast introduceerde de Grote Kamer in de zaak N./Verenigd Koninkrijk een fair balance toets. Bij het zoeken naar een 'billijk evenwicht' tussen de eisen van het algemeen belang van de gemeenschap en de eisen van de grondrechten van het individu oordeelde het Hof dat artikel 3 EVRM Verdragsluitende staten niet verplicht om leemten in medische behandeling op te vullen door gratis en onbeperkte gezondheidszorg te bieden aan buitenlanders, die geen recht hadden om te blijven. Een constatering van het tegendeel zou een te grote belasting voor de verdragsluitende staten betekenen. ${ }^{61}$ De Grote Kamer wees erop dat het EVRM - hoewel veel van de rechten die het bevat ook implicaties van sociale of economische aard hebben - in essentie gericht is op de bescherming van politieke en burgerlijke rechten. ${ }^{62}$ Binnen de Grote Kamer was hier verdeeldheid over. In hun 'joint dissenting opinion' achtten rechters Tulkens, Bonello en Spielman deze overweging in strijd met het absolute karakter van artikel 3 EVRM. Volgens hen moet deze interpretatie worden gezien als een ongepast argument om te voorkomen dat "artikel 3 EVRM in deze zaak de sluisdeuren zou openzetten voor medische immigratie en Europa kwetsbaar maakt om de ziekenboeg van de wereld te worden". ${ }^{63}$ Dit 'floodgate' argument werd volgens hen totaal verkeerd opgevat. Ook ging de Grote Kamer hiermee voorbij aan de sociale dimensie van de geïntegreerde aanpak van het Hof, met name in de zaak Airey/Ierland. ${ }^{64}$ Mantouvalou achtte de uitzetting, die een penibele situatie voor N. tot gevolg zou hebben, mogelijk in strijd met de plicht om een individu in serieus gevaar te redden. Volgens haar was in deze zaak het minimum level of severity van artikel 3 EVRM wel degelijk bereikt. ${ }^{65} \mathrm{Zij}$ wees er ook op dat budgettaire argumenten geen rol spelen in andere zaken die betrekking hebben op schending van het EVRM. Alleen wanneer er een extreem beroep wordt gedaan op de kosten, laat het principe van 'nearby rescue' ruimte voor budgettaire afwegingen. ${ }^{66}$

Het Hof heeft in geen van de daaropvolgende zaken echter aanleiding gezien om een schending van artikel 3 EVRM te constateren, op een enkele uitzondering na (Aswat/Verenigd Koninkrijk). ${ }^{67}$ Ondanks de kritiek bleef het Hof trouw aan het 'unfortunate principle'. In de zaak Yoh-Ekale Mwanie/België werd het criterium door zes rechters in hun 'partially concurring opinion' sterk betwist. ${ }^{68}$ In deze zaak beweerde verzoekster - die onder meer leed aan aids -

\footnotetext{
${ }^{60}$ A.C. Hendriks, annotatie bij: N./Verenigd Koninkrijk (supra noot 1).

${ }^{61}$ N./Verenigd Koninkrijk (supra noot 1), par. 44.

${ }^{62}$ N./Verenigd Koninkrijk (supra noot 1), par. 44.

${ }^{63}$ Joint dissenting opinion of Judges Tulkens, Bonello and Spielman in N./Verenigd Koninkrijk (supra noot 1), par 8.

${ }^{64}$ N./Verenigd Koninkrijk (supra noot 1), par. 6. Zoals we zagen in par. 6.2.2., oordeelde het Hof in Airey/Ierland dat er geen waterdichte verdeling bestaat tussen de sociaaleconomische rechten en de rechten die onder het EVRM vallen, EHRM 9 oktober 1979, nr. 6289/73 (Airy/lerland).

${ }^{65}$ Volgens Mantouvalou bestaat er zowel een morele als een bepaalde juridische plicht om naburige behoeftigen te redden, Mantouvalou The Modern Law Review, 2009/5, p. 815-843.

${ }^{66}$ Mantouvalou The Modern Law Review, 2009/5, p. 815-843.

${ }^{67}$ In de zaak Aswat/Verenigd Koninkrijk oordeelde het Hof dat uitlevering van een terrorismeverdachte aan de VS een schending van art. 3 EVRM zou opleveren omdat de Amerikaanse detentieomstandigheden de schizofrenie van de verdachte zouden (kunnen) verergeren, EHRM 16 april 2013, nr. 17299/12 (Aswat/Verenigd Koninkrijk). ${ }^{68}$ Tulkens, Jočiené, Popovič, Karakaș, Raimondi en Pinto de Albuquerque, partially concurring opinion in de zaak Yoh-Ekale Mwanje/Belgium (EHRM 20 december 2011, Requête no 10486/10), alleen beschikbaar in Frans.
} 
dat haar uitzetting naar Kameroen in strijd zou zijn met artikel 3 EVRM, aangezien zij geen toegang zou hebben tot de noodzakelijke antiretrovirale middelen, hetgeen zou leiden tot haar vroegtijdige dood. Het Hof merkte op dat de door verzoekster vereiste behandeling slechts toegankelijk was voor een klein percentage van de bevolking van Kameroen en dat haar gezondheid zonder deze geneesmiddelen zou verslechteren. Deze situatie was echter onvoldoende om een schending van artikel 3 EVRM te constateren, aangezien de verdragsluitende staten niet verplicht waren om leemten in de medische behandeling op te vullen door gratis en onbeperkte gezondheidszorg te verlenen aan buitenlanders die niet het recht hadden om te blijven (N./Verenigd Koninkrijk). In deze zaak waren er niet zulke dwingende humanitaire overwegingen als in het geval van de zaak D./Verenigd Koninkrijk. Uit de afgegeven medische attesten bleek dat haar huidige toestand niet kritiek was en dat ze geschikt was om te reizen. Uitzetting van de aanvrager naar Kameroen zou dus niet in strijd zijn met artikel 3 of artikel 2 EVRM.

De zes rechters vonden dat deze zaak op grond van dwingende humanitaire redenen een zeer hoge drempel voor schending van artikel 3 EVRM stelde. De jurisprudentie vereiste een extreem feitelijk scenario waarin een persoon zich in het laatste stadium van een ziekte (bijna dood) bevindt, zoals het geval was in de zaak St Kitts, om een schending van artikel 3 EVRM vast te stellen. Zij waren van mening dat dit niet verenigbaar was met de letter en geest van artikel 3 EVRM, gezien het fundamentele en absolute karakter van dit recht. De integriteit en de waardigheid van de persoon werd hiermee onvoldoende gerespecteerd. Het verschil tussen een persoon die op zijn sterfbed ligt en iemand die met enige vertraging tot haar sterfbed is veroordeeld, is volgens deze rechters weinig menselijk. Zij riepen de Grote Kamer op om terug te komen op het 'unfortunate principle' dat in de zaak N./Verenigd Koninkrijk was uiteengezet en dat het Hof volgens hen slechts volgde om de rechtszekerheid te behouden.

In de zaak M.T./Zweden leed klager aan een chronische nierziekte ten gevolge waarvan hij drie keer per week gedialyseerd moet worden. ${ }^{69}$ Het EHRM achtte geen schending van artikel 3 EVRM aanwezig nu in Kirgizië gratis dialyse aanwezig was in publieke ziekenhuizen en tegen een zekere vergoeding in private klinieken. Het Hof was niet overtuigd dat klager medische behandeling zou worden geweigerd bij terugkeer. Het Hof hechtte grote waarde aan de garanties van de Zweedse regering dat de immigratieautoriteiten klager zouden assisteren bij het treffen van de noodzakelijke voorbereidingen om te verzekeren dat zijn behandelingen niet zouden worden onderbroken en dat hij toegang tot medische behandeling zou krijgen bij terugkomst in zijn land van herkomst.

Sluitstuk van de 'pre-Paposhvili' jurisprudentie vormt de zaak S.J/België. In deze zaak werd de verzoeker gediagnosticeerd als hiv-positief met een ernstig tekort aan het immuunsysteem dat een antiretrovirale behandeling vereiste. ${ }^{70} \mathrm{Zij}$ stelde (onder andere) dat er zwaarwegende redenen waren om aan te nemen dat zij, indien zij naar haar land van herkomst, Nigeria, zou terugkeren, het risico zou lopen daar onmenselijk en vernederend te worden behandeld in strijd met artikel 3 EVRM. ${ }^{71}$

\footnotetext{
${ }^{69}$ EHRM 26 februari 2015, nr. 1412/12, JV 2015/107 (M.T./Zweden).

${ }^{70}$ EHRM (Grote Kamer) 27 februari 2014, nr. $70055 / 10$ (S.J./Belgï).

${ }^{71}$ Verzoekster was in de zomer van 2007 in België aangekomen en heeft toen zij acht maanden zwanger was een asielaanvraag ingediend. Op dat moment was ze minderjarig. Ze beviel van haar eerste kind in september 2007 en van een tweede kind in april 2009, het derde in 2012.
} 
Het Hof constateerde dat als verzoekster verstoken zou blijven van essentiële medicijnen, dit kon leiden tot een verslechtering van haar toestand en zelfs haar leven op korte of middellange termijn in gevaar kon brengen. Het Hof stelde echter ook vast dat de toestand van verzoekster op dat moment onder controle was, dat zij niet 'ernstig ziek' was en geschikt om te reizen. Het achtte de 'threshold of severity' niet bereikt.

Rechter Power-Forde achtte het in zijn afwijkende mening noodzakelijk om de 'uitzonderlijke omstandigheden'-test meer menselijk toe te passen. De arresten van het Hof moeten volgens hem niet alleen de stervenden, maar ook de levenden beschermen tegen een behandeling die op grond van artikel 3 van het Verdrag verboden is.

De zaak werd door de Grote Kamer doorgehaald omdat België aan verzoekster en haar kinderen alsnog een verblijfsvergunning had gegeven. ${ }^{72}$ In zijn 'dissenting opinion' bij de zaak S.J./België hield rechter Pinto de Albuquerque een ziedend betoog over de lijn van het EHRM in medische uitzettingszaken. In de kern komt deze erop neer dat onrechtmatig verblijvende vreemdelingen volgens hem geen verdragsrechtelijke bescherming genieten in die zin dat zij niet kunnen profiteren van de positieve verplichting van de staat om de voor een levensbedreigende of ernstige ziekte noodzakelijke medische behandeling te waarborgen, wanneer de voorzienbare schending van artikel 3 EVRM voortvloeit uit een natuurlijk optredende ziekte en het ontbreken van voldoende middelen om deze in het land van ontvangst te behandelen. ${ }^{73}$ Volgens Pinto de Albuquerque ontbreekt het aan enig duidelijk juridisch criterium om zowel de ernst van de ziekte als de kwaliteit en (financiële) toegankelijkheid van de behandeling in het herkomstland te beoordelen. Ook hekelde hij de onhoudbare bewijslast die op de vreemdeling rust in dit soort zaken. Het is de staat die dient te bewijzen dat uitzetting niet in strijd komt met de verdragsbepalingen. In paragraaf 6.8 .3 zal blijken dat de praktijk in Nederland nog steeds onvoldoende bescherming biedt.

\subsubsection{Paposhvili en Savran}

Pas in 2016 leek het Hof zich iets aan te trekken van de kritiek en verheldert het in de zaak Paposhivili wat dient te worden verstaan onder 'andere zeer uitzonderlijke omstandigheden. ${ }^{74}$

In de zaak Paposhvili/België (hierna: Paposhvili) ging het om een klager die in Georgië geboren was. Samen met zijn vrouw en kind vroeg hij in 1998 asiel aan in België. In België kreeg het echtpaar nog twee kinderen. In de jaren daarna werden hij en zijn vrouw meermaals veroordeeld voor verschillende strafbare feiten, waaronder diefstal en lidmaatschap van een criminele organisatie. Tijdens detentie van klager werd chronische lymfatische leukemie gediagnosticeerd. Ook leed hij aan tuberculose. Klager werd voor de leukemie behandeld door onder meer met chemotherapie en later met experimentele (dure) medicatie (Ibrutinib). Volgens zijn artsen was behandeling door gespecialiseerde hematologen noodzakelijk. Zonder de intensieve behandeling zou klager als gevolg van de leukemie overlijden. Zijn enige kans op herstel was het ondergaan van een beenmergtransplantatie. De medicatie noch een beenmergtransplantatie zou beschikbaar zijn in Georgië. In augustus 2007 werd klager ongewenst

\footnotetext{
${ }^{72}$ S.J./België (supra noot 70).

${ }^{73}$ Pinto de Albuquerque, dissenting opinion in de zaak S.J./België (supra noot 70).

${ }^{74}$ EHRM (Grote Kamer) 13 december 2016, 41738/10, ECLI:CE:ECHR:2016:1213JUDO04173810, JV 2017/22, m.nt. B.E.P. Myjer (Paposhvili).
} 
verklaard. Hij moest na het uitzitten van zijn straf België verlaten. Vanwege de intensieve medische behandeling aan het einde van zijn detentie werd dit bevel niet ten uitvoer gelegd. In 2010 vaardigden de Belgische autoriteiten alsnog een bevel uit dat klager België moest verlaten en werd hij in vreemdelingendetentie geplaatst. Klager diende op 23 juli 2010 een klacht in bij het EHRM, inhoudende dat uitzetting naar Georgië een schending zou opleveren van de artikelen 2, 3 en 8 van het EVRM. Deze klacht werd door een kamer van zeven rechters ongegrond verklaard aangezien er geen sprake was van klemmende redenen van humanitaire aard (er bestond wel enige vorm van behandeling voor leukemie in Georgië en klager zou steun van zijn broer aldaar kunnen ontvangen). Op 14 juli 2014 vroeg Paposhvili om verwijzing naar de Grote Kamer. Hij overleed vóór de uitspraak van de Grote Kamer. ${ }^{75}$

De Grote Kamer constateerde dat het tijd was voor verheldering van 'andere zeer uitzonderlijke omstandigheden'. ${ }^{76}$ Hiervan is volgens de Grote Kamer sprake als gewichtige redenen zijn aangevoerd om aan te nemen ('substantial grounds have been shown for believing') dat een ernstig zieke vreemdeling, hoewel het risico op overlijden niet direct ophanden is, bij verwijdering een reëel risico loopt op een ernstige, snelle en onomkeerbare achteruitgang van zijn gezondheidssituatie, resulterend in een intens lijden of een significante vermindering van de levensverwachting. De achteruitgang in de gezondheidssituatie moet te wijten zijn aan de afwezigheid van adequate medische behandeling in het herkomstland of gebrek aan toegang tot een dergelijke behandeling. ${ }^{77}$

Het EHRM legde vervolgens uit wie de bewijslast draagt. De bewijslat dat er gegronde redenen zijn om aan te nemen dat de vreemdeling, indien de aangeklaagde maatregel ten uitvoer zou worden gelegd, een reëel risico zou lopen op een behandeling die in strijd is met artikel 3 EVRM, ligt bij de vreemdeling. Hierbij is een zekere mate van speculatie inherent. ${ }^{78}$ Als de vreemdeling dergelijk bewijsmateriaal aanvoert, is het aan de nationale autoriteiten om de geuite twijfels weg te nemen. De vermeende risico's moeten aan een nauwkeurig onderzoek worden onderworpen. Daarbij dienen de nationale autoriteiten de algemene situatie van de gezondheidszorg in het herkomstland en de individuele omstandigheden van de vreemdeling te betrekken. Bij de beoordeling van het risico moet rekening worden gehouden met algemene bronnen zoals verslagen van de WHO of van gerenommeerde niet-gouvernementele organisaties en de geneeskundige verklaringen van de persoon in kwestie. ${ }^{79}$

Opvallend is dat het Hof de verplichting om een persoon niet bloot te stellen aan een door artikel 3 EVRM verboden risico op mishandeling als een negatieve verplichting kwalificeert. Daaruit trekt het Hof de conclusie dat de gevolgen van de verwijdering voor de betrokkene moeten worden beoordeeld door vergelijking van zijn of haar gezondheidstoestand vóór de verwijdering en de wijze waarop deze zich na de overbrenging naar de ontvangende staat zou ontwikkelen. ${ }^{80}$

Van belang voor de onderzoek plicht van de uitzettende staat is dat deze per individueel

\footnotetext{
${ }^{75}$ Zie voor de processuele aspecten van deze zaak de annotatie van B.E.P. Myjer in $J V$ 2017/22. en Wegelin A\&MR $2017 / 2$

${ }^{76}$ De Grote Kamer volgt hiermee de Third Party Intervention van het Human Rights Center of Ghent University.

${ }_{77}$ Paposhvili (supra noot 74), par. 183.

${ }^{78}$ Paposhvili (supra noot 74), par. 186.

${ }^{79}$ Paposhvili (supra noot 74), par. 187.

${ }^{80}$ Paposhvili (supra noot 74), par. 188.
} 
geval moet nagaan of de algemeen beschikbare medische zorg in het herkomstland voldoende is en geschikt is voor de behandeling van de ziekte van de aanvrager, om te voorkomen dat deze wordt blootgesteld aan een behandeling die in strijd is met artikel 3 EVRM. De maatstaf is niet of de zorg in de ontvangende staat gelijkwaardig of minderwaardig is aan de zorg die het zorgstelsel van de uitzettende staat verleent. Evenmin kan uit artikel 3 een recht worden afgeleid op een specifieke behandeling in de ontvangende staat die niet beschikbaar is voor de rest van de bevolking van het herkomstland. ${ }^{81}$

De autoriteiten moeten ook nagaan in hoeverre de betrokken persoon daadwerkelijk toegang zal hebben tot deze zorg en deze voorzieningen in de ontvangende staat. Hierbij dient rekening gehouden te worden met de kosten van medicatie en behandeling, het bestaan van een sociaal en familiaal netwerk, en de afstand die moet worden afgelegd om toegang te hebben tot de vereiste zorg. ${ }^{82}$ Indien "ernstige twijfels blijven bestaan", moet de staat van uitzetting "individuele en toereikende garanties" verkrijgen van de staat van ontvangst. ${ }^{83}$

Het Hof benadrukt dat in gevallen van verwijdering van ernstig zieke personen de gebeurtenis, die de onmenselijke en vernederende behandeling in gang zet en die de verantwoordelijkheid van de uitzettende staat op grond van artikel 3 EVRM met zich brengt, niet het gebrek aan medische infrastructuur in de ontvangende staat is. Evenzo is de uitzettende staat niet verplicht de verschillen tussen zijn gezondheidsstelsel en het niveau van de in de ontvangende staat bestaande behandeling te verkleinen door alle vreemdelingen zonder recht op verblijf binnen zijn rechtsgebied gratis en onbeperkt gezondheidszorg te bieden. ${ }^{84}$ Toegepast op de casus Paposhvili, achtte de Grote Kamer schending van artikel 3 aanwezig. ${ }^{85}$

Het Hof verruimde in de zaak Paposhivili de eisen ten opzichte van eerdere arresten in drieërlei opzichten. ${ }^{86}$ Ten eerste past het Hof de normale norm voor een reëel risico toe. Ten tweede zijn niet alleen 'onmiddellijke dood', maar ook 'intens lijden' en 'een aanzienlijke vermindering van de levensverwachting' voldoende. Ten derde is relevant of de vreemdeling daadwerkelijk toegang zou hebben tot zorg en medicatie. Desondanks handhaafde het Hof expliciet de hoge drempel in medische uitzettingszaken. ${ }^{87} \mathrm{Er}$ is meer lijden vereist dan in andere artikel 3-gevallen als minimum wordt vereist.

In de literatuur is kritiek geweest op de kwalificatie 'negatieve verplichting'. De 'very exceptional' test zou daarmee onverenigbaar zijn, want deze is ook niet van toepassing in andere zaken waar het gaat om negatieve verplichtingen. De 'fair balance' test past evenmin bij negatieve verplichtingen, maar hoort bij de positieve verplichtingen. ${ }^{88}$

In het arrest Savran/Denemarken paste het EHRM de Paposhvili-beginselen voor het eerst sinds laatstgenoemd arrest toe. ${ }^{89}$ Klager, die leed aan ernstige psychoses en andere psychiatrische aandoeningen, stelde dat hij bij terugkeer in Turkije geen reële mogelijkheid zou

\footnotetext{
${ }^{81}$ Paposhvili (supra noot 74), par. 189.

${ }^{82}$ Paposhvili (supra noot 74), par. 190.

${ }^{83}$ Paposhvili (supra noot 74), par. 191.

${ }^{84}$ Paposhvili (supra noot 74), par. 192.

${ }^{85}$ Paposhvili (supra noot 74), par. 206.

${ }^{86}$ Battjes 2019, nr. 4.

${ }^{87}$ Paposhvili (supra noot 74), par. 183, onder 4.

${ }^{88}$ Stoyanova, International Journal of Refugee Law 2017/4, p. 580-613.

${ }^{89}$ EHRM 1 oktober 2019, ECLI:CE:ECHR:2019:1001JUD005746715, JV 2020/2, m.nt. G.J. Dijkman (Savran/ Denemarken).
} 
hebben om de passende en noodzakelijke psychiatrische behandeling te krijgen. Bijgevolg zou hij een terugval van zijn ziekte krijgen en zou het risico en het lijden dat met een dergelijke terugval gepaard gaat, in strijd zijn met artikel 3 EVRM. Ook stelde klager dat hij geen sociaal netwerk had in Turkije. Daarnaast beriep klager zich op artikel 8 EVRM. Het EHRM achtte de onderzoeken van beide rechterlijke instanties 'Paposhvili-proof': onderzocht was of de medische behandeling van verzoeker in Turkije beschikbaar was en of verzoeker de facto toegang tot die behandeling zou hebben, rekening houdend met de kosten van medicatie en verzorging, de afstand die moet worden afgelegd om toegang tot verzorging te krijgen en de beschikbaarheid van medische hulp in de taal van verzoeker, een beoordeling die in overeenstemming is met de in Paposhvili genoemde criteria. Toch deelde het Hof de door het Deense hogere hof geuite bezorgdheid dat het onduidelijk was of de aanvrager een reële mogelijkheid had om relevante psychiatrische behandeling te ontvangen, met inbegrip van de noodzakelijke follow-up en controle in verband met intensieve ambulante therapie, indien hij naar Turkije zou worden teruggestuurd. ${ }^{90}$ Deze onzekerheid deed ernstige twijfels rijzen over de gevolgen van de verwijdering voor de aanvrager. Wanneer deze ernstige twijfels blijven bestaan, moet de uitzettende staat deze twijfels wegnemen of van de ontvangende staat individuele en voldoende garanties krijgen - als voorwaarde voor verwijdering - dat een passende behandeling beschikbaar en toegankelijk zal zijn voor de betrokken personen, zodat zij zich niet in een situatie bevinden die strijdig is met artikel 3. ${ }^{91}$

Met vier stemmen tegen drie oordeelde het Hof dat indien klager naar Turkije zou worden overgebracht zonder dat de Deense autoriteiten dergelijke individuele en voldoende garanties zouden hebben gekregen, er sprake zou zijn van een schending van artikel 3 EVRM. In haar dissenting opinion is rechter Mourou-Vikstrom echter van mening dat het uitzetten van vreemdelingen met psychische problematiek een andere benadering en een hogere drempel vraagt dan de Paposhvili-norm. ${ }^{92}$

\subsubsection{Tussenoverweging}

Medische uitzettingszaken hebben tot verdeeldheid binnen het EHRM geleid. Volgens rechter Pinto de Albuquerque laten de medische uitzettingszaken zien dat migranten in de EHRMrechtspraak ondermaats worden beschermd.${ }^{93}$ De drempel in medische uitzettingszaken is hoger dan in niet-uitzettingsjurisprudentie, waarin de positieve plicht om het leven te beschermen niet afhankelijk is van intens lijden of een significante daling van de levensverwachting. ${ }^{94}$ Budgettaire consequenties door verdragsverplichtingen spelen bij zaken die migranten betreffen een rol, in tegenstelling tot bijvoorbeeld de rechtspraak waar gedetineerden bij

\footnotetext{
${ }^{90}$ Savran/Denemarken (supra noot 89), par. 65.

${ }^{91}$ Savran/Denemarken (supra noot 89), par. 66.

${ }^{92}$ Additional dissenting opinion of Judge Mourou-Vikström (on paragraph 7 of the common dissenting opinion) bij Savran/Denemarken (supra noot 89).

${ }^{93}$ Gedeeltelijke dissenting opinion van rechter Pinto de Albuquerque bij EHRM (Grote Kamer) 19 december 2017, ECLI:CE:ECHR:2017:1219JUD005608013, EHRC 2018/47, m.nt. L. Lavrysen (Lopes de Sousa Fernandes/ Portugal), nr. 43 en 59.

${ }^{94}$ Den Heijer 2019, p. 10. Hij verwijst hierbij naar de zaken Vo/Frankrijk, Dodov/Bulgarije, Center of Legal Resources on behalf of Valentin Campeanu/Roemenië.
} 
betrokken zijn. ${ }^{95}$ De jurisprudentie ondermijnt het vertrouwen in de mensenrechtelijke bescherming van degenen die deze het meeste nodig hebben. ${ }^{96}$

Het 'floodgate'-argument van het Hof (N./Nerenigd Koninkrijk) is omstreden. Dit argument is in strijd met het absolute karakter van artikel 3 EVRM. Bovendien is er geen bewijs voor de stelling dat ruimhartige aanspraken op gezondheidszorg irreguliere migranten aantrekken, of dat restrictieve aanspraken irreguliere migranten aanmoedigen om het land te verlaten. Andere factoren zoals de mogelijkheid om werk te vinden en bestaande banden met familie en ander netwerk, vormen waarschijnlijk veel sterkere 'pull' factoren. ${ }^{97}$

De kritiek van Waldron dat het EHRM in zijn jurisprudentie nauwelijks reflecteert op de begrippen 'onmenselijke' en 'vernederende' behandeling, zien we bevestigd in de medische gevallenrechtspraak. Het EHRM maakt weliswaar helder welke criteria meewegen (natuurlijke oorzaak, al dan niet direct veroorzaakt door de lidstaat) maar verheldert niet welk element van artikel 3 EVRM is geschonden bij schending van dit artikel vanwege gebrek aan medische behandeling in het herkomstland: onmenselijke of vernederende behandeling. Kijkend naar het minimumniveau van ernst lijkt het gerechtvaardigd om de uitzonderingsgevallen die de minimumdrempel hebben bereikt (meestal toch zo goed als dicht bij de dood) als onmenselijk te bestempelen. De hoge drempel uit de oude jurisprudentie is nog steeds van kracht. Het lijkt erop dat het Hof gevallen van vernederende behandeling in medische zaken nog niet heeft willen aanvaarden als strijdig met artikel 3 EVRM, omdat dan de financiële druk op de lidstaten te groot zou worden. Er moet sprake zijn van een behandeling die in hoge mate vernederend is (onmenselijke behandeling) terwijl ook in vernederende zaken de menselijke waardigheid in het geding is. De Grote Kamer heeft herhaaldelijk bevestigd dat "respect for human dignity forms part of the very essence of the Convention" en dat er een bijzonder sterk verband bestaat tussen de menselijke waardigheid en artikel 3 EVRM. ${ }^{98}$ Iedere inbreuk op de menselijke waardigheid is in strijd met deze 'very essence'. ${ }^{99}$ Gezien de wijzigende opvattingen over wat onmenselijk en vernederend is en gezien het dynamische karakter van het EVRM (een 'levend instrument', dat moet worden geïnterpreteerd volgens de 'huidige omstandigheden'), is het niet ondenkbaar dat de grenzen in de toekomst verder worden opgerekt. Al heeft het Hof laten zien dit met zeer kleine stappen te doen.

\subsection{Jurisprudentie HvJ EU over uitzetting van (ernstig) zieke vreemdelingen}

De jurisprudentie van het EHRM werkt ook door in het EU-recht.

Artikel 4 van het EU-Handvest Grondrechten bevat een equivalent van artikel 3 EVRM:

"Niemand mag worden onderworpen aan foltering of aan onmenselijke of vernederende behandeling of bestraffing".

\footnotetext{
${ }^{95}$ Gedeeltelijke dissenting opinion van rechter Pinto de Albuquerque bij Lopes de Sousa Fernandes/Portugal (supra noot 93), nr. 43 en 59.

${ }^{96}$ Mantouvalou, The Modern Law Review, 2009/5, p. 815-843.

${ }^{97}$ Ingleby e.a. 2016, p. 38.

${ }^{98}$ EHRM 28 september 2015, EHRC 2015/236, m.nt. S. Smet (Bouyid/België). Het ging in deze zaak om een vernederende behandeling.

${ }^{99}$ Bouyid/België (supra noot 98), par. 101.
} 
Als rechtscorrespondenten hebben deze rechten dezelfde inhoud en reikwijdte, al belet artikel 3 EVRM niet dat het recht van de Unie een ruimere bescherming biedt (artikel 52 Handvest Grondrechten). De uitleg van artikel 4 Handvest volgt in beginsel de uitleg van artikel 3 EVRM.

De TRi regelt normen en procedures voor personen tegen wie een terugkeerbesluit is genomen. ${ }^{100}$ De TRi verplicht de lidstaten ertoe een terugkeerbesluit uit te vaardigen voor alle onderdanen van derde landen die illegaal op hun grondgebied verblijven. De richtlijn heeft een tweeledig doel: 1. een doeltreffend verwijderings- en repatriëringsbeleid, gebaseerd op gemeenschappelijke normen, voor een humane terugkeer van personen, met 2. volledige eerbiediging van hun fundamentele rechten en waardigheid. ${ }^{101}$ Lidstaten zijn op grond van artikel 14 van de TRi verplicht zo veel mogelijk de eenheid van het gezin te handhaven, dringende medische zorg en essentiële behandeling van ziekte te verstrekken.

In de zaak Abdida deed het HvJ EU voor het eerst uitspraak over het recht op elementaire sociale voorzieningen voor ernstig zieke migranten zonder verblijfsvergunning in afwachting van terugkeer. ${ }^{102}$ Het Hof oordeelde dat de TRi aan vreemdelingen wel het recht geeft om de behandeling van een beroep tegen de afwijzing van een aanvraag op medische gronden af te wachten in het gastland. Een vreemdeling, die in beroep gaat tegen de afwijzing van een aanvraag voor een verblijfsvergunning op medische gronden op basis van strijd met artikel 3 EVRM, mag tijdens de behandeling van dit beroep niet worden uitgezet. Tijdens deze periode moeten lidstaten zo veel als mogelijk voorzien in de elementaire levensbehoeften van deze vreemdelingen. Op grond van artikel 14 van de TRi moeten lidstaten in dergelijke situaties alleen voorzien in dringende medische zorg en essentiële behandeling van ziekte. Volgens het Hof is deze waarborg alleen effectief wanneer lidstaten ook voorzien in de basisbehoeften van de betrokken vreemdeling. Het Hof overweegt dat anders het recht op dringende medische zorg 'verstoken blijft van daadwerkelijke uitwerking'. ${ }^{103}$ De wijze waarop in deze basisbehoeften wordt voorzien mogen lidstaten zelf bepalen. Hiermee werken positieve verplichtingen door in het EU-recht. ${ }^{104}$

De zaak C.K./Slovenië betrof een prejudiciële vraag over de overdracht van een asielzoeker in het kader van de Dublin III-verordening. ${ }^{105}$ De vrouw leed aan ernstige psychische klachten. Het HvJ EU oordeelde dat artikel 4 van het Handvest aldus moet worden uitgelegd dat de overdracht van een asielzoeker met een ernstige mentale of lichamelijke aandoening in omstandigheden, waarin die overdracht een reëel en bewezen risico zou inhouden op een aanzienlijke en onomkeerbare achteruitgang van de gezondheidstoestand van de betrokkene, een onmenselijke en vernederende behandeling in de zin van dat artikel zou vormen. In het arrest verwijst het HvJ EU naar de EHRM jurisprudentie over medische gevallen en specifiek naar het Paposhvili-arrest. Annotator Battjes merkt op dat de drempel die het HvJ

\footnotetext{
100 Zie par. 6.6.3.

${ }^{101}$ Peers typeert deze beginselen als 'ongemakkelijke bedgenoten', Peers, European Journal of Migration and Law 2015/4 p. 289-304.

${ }^{102}$ HvJ EU 18 december 2014, nr. C-562/13, ECLI:EU:C:2014:2453, EHRC 2015/50, m.nt. M. den Heijer, JV $2015 / 59$ m.nt. F.F. Larsson (Abdida).

${ }^{103}$ Abdida (supra noot 102), onder 60.

${ }^{104}$ Hierover Beijer, NTM/NJCM-bull. 2016/14.

105 HvJ EU 16 februari 2017, nr, C-578/16 PPU, ECLI:EU:C:2017:127, JV 2017/94, m.nt. S.G. Kok (C.K./Slovenië).
} 
EU vaststelt voor Dublinoverdrachten lager lijkt dan die in Paposhvili. ${ }^{106}$ Ten eerste doordat het criterium 'aanzienlijk en onomkeerbare achteruitgang van de gezondheidstoestand' minder streng is dan het Paposhvili-criterium 'een ernstige, snelle en onomkeerbare achteruitgang van zijn gezondheidstoestand die intens lijden of een aanzienlijke vermindering van de levensverwachting tot gevolg heeft'. Ten tweede omdat het HvJ EU niet uitsluit dat de overdracht van een asielzoeker met een bijzonder slechte gezondheidstoestand op zich voor de betrokkene een reëel risico op onmenselijke of vernederende behandeling in de zin van artikel 4 van het Handvest kan inhouden, 'ongeacht de kwaliteit van de opvang en de zorg die aanwezig zijn in de lidstaat die verantwoordelijk is voor de behandeling van zijn verzoek', terwijl de achteruitgang volgens het EHRM te wijten moet zijn 'aan het ontbreken van een passende behandeling in het land van ontvangst'. De zaak C.K./Slovenië is relevant gebleken voor artikel 64-procedures. ${ }^{107}$

\subsection{Toepassing Papsoshvili-criteria in Nederland}

\subsubsection{Nationale uitvoeringspraktijk vóór Paposhvili}

In de Nederlandse uitvoeringspraktijk werd de norm 'appeared to be close to death', in het kader van asiel, ingevuld met een overlijden binnen een week na terugkeer. De individuele toegankelijkheid van de medische zorg werd niet beoordeeld. Van diverse zijden verscheen kritiek op dit beleid. De commissie Smeets adviseerde de overheid expliciet te erkennen dat, indien Nederland overgaat tot uitzetting van zieke vreemdelingen, er een morele verantwoordelijkheid van Nederland bestaat zich ervan te vergewissen of er voor betrokkene adequate gezondheidszorg aldaar voorhanden en toegankelijk is. ${ }^{108}$ De IGZ was dezelfde mening toegedaan. ${ }^{109}$ De Onderzoeksraad voor Veiligheid stelde dat het toetsen van de beschikbaarheid van medische zorg - zonder daarbij de toegankelijkheid van die zorg te beoordelen onvoldoende waarborgen - bood voor de veiligheid van de vreemdeling. ${ }^{110}$ Het duurde echter tot Paposhvili voordat er wijziging in het beleid kwam.

\subsubsection{Nationale uitvoeringspraktijk na Paposhvili}

Naar aanleiding van de zaak Paposhvili is het beleid van de Staatssecretaris in medische procedures gewijzigd. ${ }^{111}$ De feitelijke toegankelijkheid van de medische behandeling is aan de artikel 3 EVRM-toets toegevoegd.

Volgens de huidige regeling is uitsluitend sprake van een reëel risico op schending van artikel 3 EVRM: ${ }^{112}$

\footnotetext{
106 Battjes 2019, nr. 7.

107 Zie Ten Berg en Peters, A\&MR 2019/5, p. 231.

${ }^{108}$ Commissie Smeets 2004, aanbeveling 12.

${ }^{109}$ IGZ 2006.

${ }^{110}$ Onderzoeksraad voor Veiligheid 2014, p. 100.

111 Besluit van de Staatssecretaris van Veiligheid en Justitie van 29 augustus 2017, nummer WBV 2017/8, houdende wijziging van de Vreemdelingencirculaire 2000.

${ }^{112}$ Paragraaf A3/7.1.3 Vreemdelingencirculaire 2000.
} 
1. als uit het advies van het BMA blijkt dat het achterwege blijven van de medische behandeling naar alle waarschijnlijkheid zal leiden tot een medische noodsituatie en

2. als de noodzakelijke medische behandeling in het land van herkomst of bestendig verblijf niet beschikbaar is; of

3. als in geval de noodzakelijke medische behandeling wel beschikbaar is, gebleken is dat deze aantoonbaar niet toegankelijk is.

\section{Ad 1 Medische noodsituatie}

Onder een medische noodsituatie verstaat de IND: die situatie waarbij de vreemdeling lijdt aan een aandoening, waarvan op basis van de huidige medisch-wetenschappelijke inzichten vaststaat dat het achterwege blijven van behandeling binnen een termijn van drie maanden zal leiden tot overlijden, invaliditeit of een andere vorm van ernstige geestelijke of lichamelijke schade. ${ }^{113}$ Het BMA legt dit als volgt uit: "Het achterwege blijven van de medische behandeling zal naar alle waarschijnlijkheid op korte termijn leiden tot betrokkenes overlijden, een (vrijwel) volledig verlies van ADL-zelfstandigheid (activiteiten dagelijks leven) of gedwongen opname in een psychiatrisch ziekenhuis." ${ }^{114}$ Een medisch adviseur mag van deze nadere uitleg uitgaan. ${ }^{115}$

\section{Ad 2 Beschikbaarheid}

Beschikbaarheid van een medische behandeling houdt volgens het BMA Protocol in dat een gevraagde medische behandeling aanwezig is op enige plek op een bepaald moment in het gevraagde land van herkomst of land van bestemming. ${ }^{116}$

De IND concludeert dat de medische behandeling niet in het land van herkomst (of een ander land waar de vreemdeling naar kan vertrekken) beschikbaar is als, in één van de volgende gevallen: ${ }^{117}$

- uit het BMA-advies blijkt dat in het desbetreffende land geen of onvoldoende behandelmogelijkheden aanwezig of beschikbaar zijn;

- uit het BMA-advies blijkt dat in het desbetreffende land onderbrekingen in de medicijnvoorraden voorkomen, die een maand of langer duren;

- het BMA vanwege de situatie in het land van herkomst niet in staat is om te adviseren over de aanwezigheid van behandelmogelijkheden in het land van herkomst; of

- uit het BMA-advies blijkt dat, ter voorkoming van een medische noodsituatie, mantelzorg noodzakelijk is voor het slagen van de medische behandeling, terwijl de vreemdeling heeft aangetoond deze mantelzorg in het land van herkomst niet te kunnen

\footnotetext{
${ }^{113}$ Paragraaf A3/7.1.3 Vreemdelingencirculaire 2000.

114 Protocol Bureau Medische Advisering, april 2016, p. 13 (ind.nl).

${ }^{115}$ CTG 20 augustus 2012, C.2011.395.

116 Protocol Bureau Medische Advisering p. 8.

${ }^{117}$ Paragraaf A3/7.1.4 Vreemdelingencirculaire 2000.
} 
ontvangen van één of meer gezins- of familieleden dan wel via professionele (thuis)zorg.

Het BMA kan bij het beschikbaarheidsonderzoek gebruik maken van de informatiebronnen International SOS, Allianz Global Assistance. ${ }^{118}$

\section{Ad 3 Toegankelijkheid}

Bij de individuele toegankelijkheid van de medische zorg gaat het om de aspecten bereikbaarheid, betaalbaarheid en feitelijke beschikbaarheid van de geïndiceerde behandeling voor de individuele vreemdeling. ${ }^{119}$ De medisch adviseur van het BMA dient zich tot de medische aspecten en kan geen oordeel geven over economische toegangsaspecten. Ook doet hij geen uitspraken over de (on)veiligheid van de behandelomgeving. ${ }^{120}$

Als het BMA concludeert dat behandeling aanwezig is, keert de bewijslast volgens het beleid weer terug naar de vreemdeling. Deze dient aan te tonen dat de behandeling voor hem niet toegankelijk is. ${ }^{121}$ Daarbij rust de bewijslast inhoudende dat de vreemdeling geen toegang zal hebben tot de vereiste medische zorg, op de vreemdeling.

Als de vreemdeling zijn identiteit en nationaliteit niet heeft aangetoond middels documenten, kan hij in beginsel niet aannemelijk maken dat de noodzakelijke medische zorg in het land van herkomst of het land waarnaar hij kan vertrekken voor hem niet toegankelijk is.

De omstandigheid dat een vreemdeling enkel aangeeft dat de kosten voor een medische behandeling hoog zijn of dat de plek, waar de medische behandeling kan plaatsvinden, ver weg is van de woonplaats van de vreemdeling, vormt onvoldoende reden om een reëel risico op schending van artikel 3 EVRM aan te nemen. De IND kent geen betekenis toe aan niet onderbouwde stellingen over enig beletsel dat in de weg staat aan het verkrijgen van toegang tot de benodigde zorg.

Als de vreemdeling heeft gereageerd op het verzoek van de IND en daarbij voldoende aannemelijk heeft gemaakt dat de medische zorg voor hem niet toegankelijk is, dan vraagt de IND in beginsel aan de Dienst Terugkeer \& Vertrek (DT\&V), uitvoerder van het terugkeerbeleid, om te onderzoeken of de vreemdeling direct aansluitend op zijn terugkeer feitelijke toegang tot medische zorg zal kunnen krijgen. Gedurende deze periode wordt aan de vreemdeling uitstel van vertrek verleend. Zodra het onderzoek van DT\&V gereed is, wordt een definitief besluit over het verleende uitstel van vertrek gegeven. Aan de uitzetting van de vreemdeling kan het BMA reisvoorwaarden stellen zoals het meegeven van medicijnen en begeleiding door een verpleegkundige tijdens de reis.

\subsubsection{Nederlands beleid EHRM-proof?}

In de literatuur is erop gewezen dat het Nederlandse beleid niet 'Paposhvili-proof' zou zijn. ${ }^{122}$ Zo stellen Ten Berg en Peters de vraag of het gelijkstellen van 'een snelle achteruitgang' aan

\footnotetext{
118 Protocol Bureau Medische Advisering p. 8.

${ }^{119}$ Protocol Bureau Medische Advisering p. 10.

${ }^{120}$ Protocol Bureau Medische Advisering p. 11.

${ }^{121}$ Paragraaf A3/7.1.5 Vreemdelingencirculaire 2000.

122 Onder meer Ten Berg en Peters, A\&MR 2019/5, Den Exter 2019, EJHL 2019/2, p. 115-124, G.J. Dijkman, annotatie bij: Savran/Denemarken (supra noot 89).
} 
een termijn van drie maanden terecht is. ${ }^{123}$ Dit is echter inmiddels door de Afdeling bestuursrechtspraak wel goedgekeurd. ${ }^{124}$ Ook is aangevoerd dat ook andere dan in het Protocol genoemde situaties - overlijden, een (vrijwel) volledig verlies van ADL-zelfstandigheid of gedwongen opname in een psychiatrisch ziekenhuis - denkbaar zijn waarbij sprake is van een 'ernstige, snelle en onomkeerbare achteruitgang van de gezondheidssituatie, resulterend in een intens lijden of een significante vermindering van de levensverwachting'. ${ }^{125}$ Ook bij het criterium 'aantoonbaar niet toegankelijk' zijn vraagtekens gezet over de verenigbaarheid met Paposhvili, waarin het EHRM opmerkt dat een zekere mate van speculatie inherent is aan het preventieve doel van artikel 3 EVRM en dat niet vereist is dat de vreemdeling een duidelijk bewijs levert van zijn stelling dat hij wordt blootgesteld aan een verboden behandeling. ${ }^{126} \mathrm{De}$ zware bewijslast van de vreemdeling tenslotte staat op gespannen voet met EVRMjurisprudentie. ${ }^{127}$ Als uit BMA blijkt dat behandeling aanwezig is, dient de vreemdeling aan te tonen dat deze behandeling voor hem niet toegankelijk is. In de praktijk wordt het tegenbewijs echter vrijwel nooit aanwezig geacht. ${ }^{128}$ Den Exter concludeert op basis van jurisprudentieonderzoek dat de zware bewijslast het praktisch onmogelijk maakt om aan de Paposhvili standaard te voldoen. ${ }^{129}$ De zware bewijslast die de vreemdeling draagt, volgt niet zonder meer uit de Paposhvili uitspraak (waarin het Hof immers had bepaald dat het aan de autoriteiten is om de geuite twijfels weg te nemen) en kan leiden tot situaties die het EHRM in Paposhvili juist heeft willen voorkomen. ${ }^{130}$ Het lijkt er op dat de Nederlandse situatie nog onder de Paposhvili norm zit, waardoor onvoldoende bescherming wordt geboden aan de ernstig zieke vreemdeling, althans in elk geval de ernstig, maar minder kritieke, zieke vreemdelingen.

\subsection{Conclusie}

Het is vaste EHRM-jurisprudentie dat zieke vreemdelingen niet kunnen blijven profiteren van medische zorg voorzien door de uit te zetten staat. Dat is alleen mogelijk in uitzonderlijke gevallen, waarin er dwingende humanitaire gronden zijn. Evenmin kan uit artikel 3 EVRM een recht worden afgeleid op een specifieke behandeling in de ontvangende staat die niet beschikbaar is voor de rest van de bevolking in het herkomstland.

De drempel voor de vaststelling van een inbreuk op artikel 3 EVRM is (nog steeds) bijzonder hoog. Het lijkt zeer onwaarschijnlijk dat deze hoge drempel op korte termijn wordt verlaagd. Het EHRM is daar consistent in, ondanks velerlei kritiek en verdeeldheid onder de

\footnotetext{
${ }^{123}$ Ten Berg en Peters, A\&MR 2019/5, p. 229.

124 Dit argument werd aangevoerd door een vreemdeling met een PTSS in ABRvS 28 september 2017, ECLI:NL:RVS:2017:2627, ABRvS 28 september 2017, ECLI:NL:RVS:2017:2628. De ABRvS achtte de beoordelingswijze van de Staatssecretaris (te weten dat hij in het kader van een beroep op de 'andere zeer uitzonderlijke omstandigheden' als bedoeld in het arrest Paposhvili allereerst beoordeelt, aan de hand van het ten behoeve van hem door het BMA uitgebrachte medische advies, of het uitblijven van behandeling naar alle waarschijnlijkheid zal leiden tot een medische noodsituatie op korte termijn) in overeenstemming met de maatstaf die het EHRM het arrest Paposhvili heeft geformuleerd.

125 ABRvS 28 september 2017, ECLI:NL:RVS:2017:2627, r.o. 6.2.

126 Ten Berg en Peters, A\&MR 2019/5, p. 228.

${ }^{127}$ G.J. Dijkman, annotatie bij: Savran/Denemarken (supra noot 89), Ten Berg en Peters 2019, A\&MR 2019/5, p. 230, Den Exter 2019, EJHL 2019/2, p. 115-124.

${ }^{128}$ G.J. Dijkman, annotatie bij: Savran/Denemarken (supra noot 89).

${ }^{129}$ Den Exter 2019, EJHL 2019/2, p. 115-124.

${ }^{130}$ Ten Berg en Peters, A\&MR 2019/5, p. 230.
} 
rechters van het EHRM. De interpretatie van 'dwingende humanitaire overwegingen' komt dicht in de buurt van de bescherming van het recht op leven (artikel 2 EVRM). De vraag is of dit recht doet aan het beginsel van menselijke waardigheid dat door artikel 3 EVRM dient te worden beschermd. De drempel mag niet zo hoog worden dat de menselijke waardigheid in het geding komt als gevolg van andere dwingende belangen. Onmenselijke behandeling van zieke personen, of zij nu legaal of illegaal in de Europese Unie verblijven, is in strijd met de menselijke waardigheid en moet daarom niet worden aanvaard.

De hoge drempel in de jurisprudentie van het Hof impliceert niet dat de bescherming uit hoofde van artikel 3 EVRM, zoals die door het Hof wordt geboden, een maximale bescherming is. Het staat de lidstaten vrij om vreemdelingen met medische problemen meer bescherming te bieden dan in de jurisprudentie wordt geboden. Het sociale recht op gezondheid is een eigenstandig recht dat meer bescherming verdient dan alleen de minimumgrenzen van deze klassieke rechten. De minimumgrens hangt nauw samen met de vraag wanneer het als onmenselijk wordt beschouwd als de zieke vreemdeling de benodigde medische behandeling in land van herkomst ontbeert.

Het valt nog te bezien in hoeverre de verschuiving van 'bijna-dood' naar 'ernstige, snelle en onomkeerbare achteruitgang van zijn gezondheidssituatie, resulterend in een intens lijden of een significante vermindering van de levensverwachting' een daadwerkelijk fundamentele verschuiving betekent voor de Nederlandse rechtspraktijk. Dit nieuwe criterium is nog niet volledig vertaald in beleid, aangezien het BMA het 'intens lijden' beperkt tot twee situaties. Buiten deze situaties kan zich echter ook intens lijden voordoen. Door deze niet te includeren kan de menselijke waardigheid in het geding komen. Bovendien maakt de zware bewijslast het praktisch onmogelijk om aan de Paposhvili standaard te voldoen.

Zodra de vreemdeling een succesvol beroep heeft gedaan op artikel 3 EVRM, valt hij onder de Rza en heeft hij meer aanspraken op zorg dan de onrechtmatig verblijvende vreemdeling (zoals vergoeding van tolkkosten (telefonisch), mondzorg en fysiotherapie) op grond van de RMA. 


\title{
Hoofdstuk 8 Juridische houdbaarheid van het koppelingsbeginsel in relatie tot artikel 122a Zvw
}

\author{
Boeles vraagt zich in zijn oratie af welke rol juristen \\ kunnen spelen om de menselijke waardigheid in \\ het vreemdelingenrecht te garanderen. Hij acht het \\ van wezenlijk belang voor een menswaardige \\ rechtsstaat dat de wetgever het humanitaire \\ vangnet laat bestaan. De overheid moet de vrijheid \\ houden om ten gunste van individuele gevallen af \\ te wijken van de harde lijn van de wet. Of de vele \\ amendementen van de Koppelingswet daartoe \\ voldoende bijdragen, zal volgens hem nog moeten \\ blijken.
}

Bron: Boeles 1997, p. 13.

\subsection{Inleiding}

$\mathrm{Na}$ de analyse van het recht op zorg voor de gezondheid van de irreguliere migrant en de bespreking van de uitzettingsjurisprudentie van het EHRM van de doodzieke vreemdeling, vangt nu het evaluerende deel van dit proefschrift aan.

Dit hoofdstuk grijpt terug op de Koppelingswet. Zoals we zagen in hoofdstuk drie, was de kritiek op deze wet dat deze in strijd zou zijn met het discriminatieverbod en internationale grond- en mensenrechten. Daarnaast zou de wet niet proportioneel zijn.

Sinds de inwerkingtreding van de Koppelingswet is een scala aan jurisprudentie over de rechtmatigheid van het koppelingsbeginsel verschenen. In deze jurisprudentie wordt met een beroep op internationale normen - waaronder het recht op gezondheidszorg - getracht het koppelingsbeginsel buiten toepassing te verklaren. Dit hoofdstuk gaat in op de jurisprudentie over de rechtmatigheid van het koppelingsbeginsel. Nu medisch noodzakelijke zorg een uitzondering is op de Koppelingswet, kan worden tegengeworpen dat het bespreken van de rechtmatigheid van deze wet niet relevant is. Het tegendeel is echter waar. Zoals we zagen in hoofdstuk vier, is de uitzondering 'medisch noodzakelijke zorg' immers een schijnuitzondering op het koppelingsbeginsel. Jurisprudentie over de rechtmatigheid van het koppelingsbeginsel kan dan ook van invloed zijn op de ontkoppeling van de onrechtmatig verblijvende vreemdeling van de Zvw en de Wlz. Met het begrip 'juridische houdbaarheid' in de titel van dit hoofdstuk doel ik op de vraag in hoeverre het beginsel stand heeft gehouden in de jurisprudentie (de rechtmatigheid in het licht van internationale verdragen) en in welke gevallen de rechter het beginsel in individuele gevallen buiten toepassing verklaart.

Het hoofdstuk beoogt antwoord te geven op deelvraag drie: 'Hoe functioneert het 
koppelingsbeginsel in de praktijk, specifiek met betrekking tot aanspraken op medische zorg'?

De indeling van het hoofdstuk is van algemeen naar bijzonder. Het vangt aan met een analyse van de jurisprudentie over de rechtvaardiging van het koppelingsbeginsel in het licht van internationale verdragen. Niet alle jurisprudentie over het koppelingsbeginsel is in het bestek van dit proefschrift relevant en wordt besproken, aangezien het beginsel de gehele sociale zekerheidswetgeving betreft. Daarom is een selectie gemaakt van jurisprudentie die enerzijds relevant is voor de vraag naar de rechtvaardiging van het koppelingsbeginsel op zich en anderzijds voor het recht op zorg voor de gezondheid van de onrechtmatig verblijvende vreemdeling. Onderzocht wordt welke uitzonderingen op het koppelingsbeginsel door de rechter zijn aanvaard, specifiek met betrekking tot medische zorg. Vervolgens wordt onderzocht hoe de bijdrageregeling zich tot deze jurisprudentie verhoudt. Tot slot volgt een bespreking van mogelijkheden om het huidige systeem (te weten: een 'indirecte' uitzondering) te wijzigen.

\subsection{Rechterlijke toetsing koppelingsbeginsel}

\subsubsection{Inleiding}

Het koppelingsbeginsel heeft veelvuldig onder vuur gelegen in jurisprudentie over sociale zekerheid. Pogingen om het koppelingsbeginsel te doorbreken worden doorgaans gestoeld op een beroep op internationale discriminatieverboden (onderscheid wegens nationaliteit of verblijfsstatus) en/of een beroep op strijd met internationale materiële normen zoals artikel 8 EVRM en bepalingen van het IVRK.

\subsubsection{Beroep op internationale anti-discriminatiebepalingen}

Enkele jaren na de inwerkingtreding van de Koppelingswet oordeelde de CRvB over de rechtvaardiging van het koppelingsbeginsel bezien vanuit diverse internationale antidiscriminatiebepalingen, zoals artikel 14 EVRM, artikel 26 IVBPR en verschillende verdragen inzake sociale zekerheid. ${ }^{1}$ De Centrale Raad kwalificeerde het onderscheid in de koppelingswetgeving primair als een onderscheid naar nationaliteit, omdat de wet aan vreemdelingen onder bepaalde voorwaarden rechten toekent die aan Nederlanders zonder voorwaarden worden toegekend. Deze kwalificatie had tot gevolg dat de Centrale Raad volgens rechtspraak van het EHRM diende te toetsen of er voor de rechtvaardiging van dit onderscheid 'very weighty reasons' (zeer gewichtige redenen) moeten bestaan. ${ }^{2}$ De Centrale Raad achtte een 'toereikende rechtvaardiging' aanwezig voor het in de koppelingswet gemaakte onderscheid. In deze uitspraak en vele andere uitspraken, achtte de Centrale Raad de doelstelling van de koppelingswetgeving zoals deze in de wetsgeschiedenis is neergelegd (geen aanspraak op uitkering bij wederrechtelijk verblijf in Nederland en voorkomen van schijnlegaliteit) aanvaardbaar, dit mede ter ondersteuning van een consistent vreemdelingenbeleid, dat onder meer tot doel heeft degenen die geen toelating verkrijgen het land te doen verlaten. ${ }^{3}$ Voorts heeft de Centrale Raad steeds geoordeeld dat het in de koppelingswetgeving ter

\footnotetext{
${ }^{1}$ CRvB 26 juni 2001, 99/2382, ECLI:NL:CRVB:2001:AB2276, USZ 2001/183, m.nt. Red.

${ }^{2}$ Zie ook par. 6.6.2 van dit proefschrift.

${ }^{3}$ CRvB 26 juni 2001, 99/2382, ECLI:NL:CRVB:2001:AB2276, USZ 2001/183, m.nt. Red.
} 
verwezenlijking van deze doelstelling gehanteerde middel in het algemeen niet op bedenkingen stuit. ${ }^{4}$ De Hoge Raad ging later mee in het oordeel van de Centrale Raad dat er voor het gemaakte onderscheid naar nationaliteit een toereikende rechtvaardiging bestaat. ${ }^{5}$ Het koppelingsbeginsel werd dus door de hoogste rechters geaccepteerd.

In 2006 werd in het kader van bijstandsverlening een succesvol beroep gedaan op het IVRK. ${ }^{6}$ Minderhoud noemde dit het eerste serieuze scheurtje in het koppelingsbeginsel. ${ }^{7}$ Het ging in deze zaak om het onthouden van bijstand aan rechtmatig in Nederland verblijvende kinderen van onrechtmatig verblijvende ouders, die niet in staat waren hun kinderen te onderhouden vanwege het bestaan van een noodsituatie. Daarbij oordeelde de Centrale dat de Koppelingswet gedeeltelijk in strijd is met artikel 2, lid 1 van het IVRK. De Nederlandse staat heeft welbewust een zekere uit het IVRK voortvloeiende zorgplicht ten opzichte van juist deze kinderen op zich genomen, aldus de Centrale Raad. Ten aanzien van niet-rechtmatig verblijvende kinderen echter achtte de Centrale Raad de uitsluiting van de bijstand in het licht van het IVRK in beginsel een evenredig middel ter verwezenlijking van de koppelingswetgeving. ${ }^{8}$

In 2008 erkende de Centrale Raad voor het eerst dat het weigeren van bijstand in strijd kan komen met artikel 8 EVRM. ${ }^{9}$ In deze zaak - waarbij het ging om bijzondere bijstand in de vorm van schoolkosten van een onrechtmatig verblijvende vreemdeling - werd een beroep op artikel 8 EVRM afgewezen omdat de weigering van bijstand niet tot effect had dat de normale ontwikkeling van het privéleven van appellant onmogelijk werd gemaakt. In deze zaak overwoog de Centrale Raad dat artikel 8 ook relevant is in zaken die betrekking hebben op de besteding van publieke middelen, maar dat de staat in dergelijke zaken een extra ruime "margin of appreciation" toekomt. Bovendien kent EHRM, bij de bepaling van de bescherming die betrokkenen genieten onder het EVRM, belang toe aan de al dan niet legale status van het verblijf van betrokkene (N/Verenigd Koninkrijk). ${ }^{10}$ Ook een beroep op sociaaleconomische rechten van onder meer het ESH en IVESCR mocht niet baten, omdat deze bepalingen volgens de Centrale Raad niet een ieder verbindend zijn in de zin van artikel 94 Gw.

Een beroep op artikel 8 EVRM slaagde wel in een zaak van een rechtmatig verblijvende vreemdeling met een lange psychiatrische geschiedenis en psychische klachten die uitgesloten was van de Wet werk en bijstand (WWB). ${ }^{11}$ De voorzieningenrechter van de Centrale Raad oordeelde dat de normale ontwikkeling van het privé- en gezinsleven van verzoeker onmogelijk werd gemaakt en dat sprake was van een zodanige aantasting van de 'very essence' van artikel 8 van het EVRM dat dit zou moeten leiden tot de positieve verplichting van de staat om bijstand te verlenen. In dit geval was bij uitsluiting van bijstand geen sprake van een 'fair balance' tussen de met het koppelingsbeginsel nagestreefde publieke belangen en de particuliere belangen van

\footnotetext{
${ }^{4}$ CRvB 19 april 2010, ECLI:NL:CRVB:2010:BM1992, JV 2010/292, m.nt. P.E. Minderhoud. Zie ook par. 8.2.3.2 van dit proefschrift.

${ }^{5}$ HR 12 februari 2010, ECLI:NL:PHR:2010:B19729, BNB 2010/133, m.nt. P. Kavelaar.

${ }^{6}$ CRvB (vzr.) 8 augustus 2005, 05/3801 en 05/3803 WWB-VV, LJN AU0687, AB 2005, USZ 2005, 333, m.nt. Red.

${ }^{7}$ Minderhoud, NTM/NJCM-Bull. 2012/4, p. 391-407.

${ }^{8}$ CRvB 24 januari 2006, ECLI:NL:CRVB:2006:AV0197, RSV 2006/84, m.nt. G. Vonk.

${ }^{9}$ CRvB 22 december 2008, ECLI:NL:CRVB:BG8789, AB 2009, 176, m.nt. I. Sewandono.

${ }^{10}$ CRvB 22 december 2008, ECLI:NL:CRVB:BG8789, AB 2009, 176, m.nt. I. Sewandono, r.o. 4.3.

${ }^{11}$ CRvB (vzr.) 7 juli 2009, 09/2715 WWB-VV, ECLI:NL:CRVB:2009:BJ2809, USZ 2009, 266.
} 
verzoeker. Het koppelingsbeginsel zoals vervat in de WWB werd doorbroken.

In 2011 kende de Centrale Raad niet-rechthebbende ouders een aanspraak op een uitkering op grond van de Algemene Kinderbijslagwet (AKW) toe. ${ }^{12}$ Van belang was dat het ging om ouders die al langere tijd samen met hun kinderen in Nederland verbleven, waarvan voor een deel rechtmatig. Daardoor werden zij als ingezetenen aangemerkt. Gezien deze omstandigheden achtte de Centrale Raad de algemene uitsluiting van het recht op kinderbijslag ${ }^{13}$ op grond van hun verblijfsstatus geen evenredig middel om de doelstelling van de koppelingswetgeving te bereiken. Volgens de Centrale Raad had de Nederlandse staat welbewust aanvaard dat deze mensen gedurende een geruime tijd hier verbleven. Daarbij overwoog de Centrale Raad dat de Staat naast een uit artikel 8 EVRM voortvloeiende zorgplicht om het recht op privé- en gezinsleven te beschermen, ook welbewust een zekere, uit het IVRK voortvloeiende zorgplicht ten opzichte van de kinderen op zich heeft genomen. Dit gold volgens de Centrale Raad met name voor die gevallen waarin het verblijf zo langdurig is dat het gezin een duurzame band met Nederland heeft kunnen opbouwen en inmiddels onderdeel uitmaakt van de Nederlandse samenleving.

In cassatie hield deze uitspraak echter geen stand. ${ }^{14}$ In tegenstelling tot de Centrale Raad oordeelde de Hoge Raad dat de regeling in artikel 6 lid 2 AKW geen onderscheid maakt dat uitsluitend op nationaliteit is gebaseerd. De regeling maakt immers mede onderscheid op basis van verblijfsstatus. Een onderscheid naar verblijfsstatus behoeft niet te worden gerechtvaardigd door zeer gewichtige redenen. Bepalend is of een dergelijk onderscheid wordt gerechtvaardigd door toereikende argumenten, 'sufficient reasons' (als bedoeld in Niedzwiecki/Duitsland ${ }^{15}$ ). De Hoge Raad overwoog onder meer dat van belang is dat het (deels langdurig) verblijf in Nederland zonder verblijfsvergunning geen inherent en onveranderlijk kenmerk van de persoon is, maar een element van keuze bevat. ${ }^{16}$ De Hoge Raad oordeelde dat het onderscheid bij de afbakening van de kring van verzekerden in redelijke en proportionele verhouding stond tot het legitieme doel, zodat voor dat onderscheid ook in het geval van belanghebbenden een toereikende rechtvaardiging bestond. ${ }^{17}$ Dat zij met medeweten van de Staat langdurig in Nederland verbleven, deed aan dat oordeel niet af. ${ }^{18}$ Daarnaast nam de Hoge Raad mede in aanmerking het doel van de Koppelingswet (ondersteuning van het Nederlandse immigratiebeleid) en de ruime beoordelingsvrijheid die de Staat in sociale zekerheidszaken heeft. Ook achtte de Hoge Raad geen strijd met artikel 26 IVBPR, bepalingen uit het IVRK ${ }^{19}$, artikel 8 in samenhang met artikel 14 EVRM of artikel 1 van het Twaalfde Protocol bij het EVRM aanwezig. In zijn annotatie wijst Minderhoud op het belang van aanpassing van wetgeving, nu de Hoge Raad

\footnotetext{
12 CRvB 15 juli 2011, 08/6595 AKW, ECLI:NL:CRVB: 2011:BR1905, 08-6595 AKW, JV 2011/393 (m.nt. Minderhoud). Een beroep op het IVRK deed volgens de Centrale Raad geen recht op kinderbijslag voor het kind ontstaan, aangezien dit geen recht is van het kind maar van de ouders, CRvB 24 januari 2006, nr. 05/3621+3622, RSV 2006/84 en CRvB 7 april 2008, 06/2792, RSV 2008/211.

${ }^{13}$ Art. 6 lid 2 AKW.

${ }^{14}$ HR 23 november 2012, ECLI:NL:HR:2012:BW7740, JV 2013/115, m.nt. P.E. Minderhoud.

${ }^{15}$ EHRM 25 oktober 2005, EHRC 2005/121, m.nt. F.M.J. den Houdijker (Niedzwiecki/Duitsland).

${ }^{16}$ HR 23 november 2012, ECLI:NL:HR:2012:BW7740, JV 2013/115, m.nt. P.E. Minderhoud, r.o. 3.5.6.

${ }^{17}$ R.o. 3.5.11.

${ }^{18}$ R.o. 3.4.12.

${ }^{19}$ In het bijzonder de artikelen 2, 3, 26 en 27.
} 
eerdere jurisprudentie over het koppelingsbeginsel deels terugdraaide. ${ }^{20}$

De Afdeling bestuursrechtspraak was eveneens van oordeel dat voor het gemaakte onderscheid naar nationaliteit en verblijfsstatus (in het kader van de Awir) in beginsel een redelijke en objectieve rechtvaardiging bestaat. Zoals gezegd, sluit het koppelingsbeginsel in de Awir Nederlanders of rechtmatig in Nederland verblijvende vreemdelingen uit van huurtoeslag, zorgtoeslag of kindgebonden budget als de partner of medebewoner geen rechtmatig verblijf heeft (zogenoemd 'doorkoppelingsbeginsel'). ${ }^{21}$ Onder zeer bijzondere omstandigheden is de weigering om een dergelijke toeslag of kindgebonden budget te verstrekken in strijd met het verbod op een ongerechtvaardigd onderscheid. ${ }^{22}$ Ook getoetst aan het IVRK achtte de Afdeling bestuursrechtspraak de doelstelling van de koppelingswetgeving niet ongeoorloofd. Wel brengt de bijzondere beschermingswaardigheid van kinderen die ten grondslag ligt aan het IVRK en in het bijzonder artikel 2 van het IVRK, met zich dat maatregelen die ten opzichte van volwassenen in overeenstemming worden geacht met de internationale non-discriminatiebepalingen, in bepaalde situaties door de gevolgen daarvan voor kinderen niettemin in strijd kunnen komen met artikel 2, eerste lid, van het IVRK. ${ }^{23}$

Inmiddels heeft ook het EHRM zich over het koppelingsbeginsel uitgesproken. In de zaak Yeshtla/Nederland onderschreef het EHRM de hierboven geschetste wijze waarop de Afdeling bestuursrechtspraak het koppelingsbeginsel toetst aan de artikelen 8 en 14 EVRM. ${ }^{24}$ Als het gaat om economische of sociale beleidskeuzes, is de reikwijdte van de 'margin of apprecation' volgens het EHRM een ruime. Daarbij kan rekening worden gehouden met de al dan niet legale status van de betrokkene. ${ }^{25}$ Het EHRM accepteerde de redenering van de Afdeling dat alleen in bijzondere omstandigheden behoeft te worden afgeweken van het koppelingsbeginsel. ${ }^{26}$ In het geval van Yeshtla was volgens het EHRM geen sprake van zeer bijzondere omstandigheden. ${ }^{27}$ Wanneer daar wel sprake van is, liet het Hof in het midden.

Het VN-Mensenrechtencomité daarentegen liet zich kritischer uit over (afwijken van) het koppelingsbeginsel in een zaak over de afwijzing van een aanvraag voor een kindgebonden budget van een staatloze vrouw zonder verblijfsvergunning. ${ }^{28}$ Het VN-Mensenrechtencomité oordeelde dat Nederland artikel 24 lid 1 IVBPR heeft geschonden. ${ }^{29}$ Daarbij overwoog het

\footnotetext{
${ }^{20}$ Minderhoud, annotatie bij: HR 23 november 2012, ECLI:NL:PHR:2012:BW7740, JV 2013/115.

${ }^{21}$ Zie par. 3.2.3.

${ }^{22}$ Voor het eerst was volgens de Afdeling bestuursrechtspraak sprake van dergelijke bijzondere omstandigheden in ABRvS 30 januari 2014, ECLI:NL:RVS:2014:378, JV 2014/393, m.nt. P.E. Minderhoud. De bijzondere omstandigheden bestonden in de ernstige gezondheidssituatie van de echtgenote van appellant (schildklierkanker) waardoor zij haar studie niet kon voortzetten en haar rechtmatig verblijf in Nederland niet kon voortzetten en de kwetsbaarheid van hun kind. De Afdeling bestuursrechtspraak achtte het na elf maanden stopzetten van de toeslagen een onevenredig middel om het doel van het koppelingsbeginsel te bereiken.

${ }^{23}$ ABRvS 18 januari 2017, ECLI:NL:RVS:2017:105. Zie ook ABRvS 24 juli 2019, ECLI:NL:RVS:2019:2540, JV 2019/159.

${ }^{24}$ EHRM 15 januari 2019, 37115/11, EHRC 2019/100, m.nt. P.E. Minderhoud (Yesthla/Nederland).

${ }^{25}$ Zie onder meer EHRM 27 mei 2008, appl. no. 26565/05 (N./VK), EHRC 2008/91.

${ }^{26}$ Yesthla/Nederland, r.o. 39.

${ }^{27}$ Door de beëindiging van de huurtoeslag stelde klaagster gedwongen te zijn om haar (meerderjarige) inwonende zoon het land uit te laten gaan ofwel haar huurtoeslag te verliezen en daardoor in financiële problemen te komen. De moeder was vanwege een hiv-infectie ernstig hulpbehoevend en afhankelijk van de zorg van haar zoon.

28 VN-Mensenrechtencomité 26 maart 2019, 2498/2014, RSV 2019/262, m.nt. P.E. Minderhoud (Abdoellaevna/Nederland), r.o. 7.9.

${ }^{29}$ Dit artikel bevat voor staten een positieve verplichting om kinderen te beschermen. Het kan hierbij ook gaan om het garanderen van een bestaansminimum. Hoewel een kindgebonden budget aan klaagster zou worden verleend
} 
Comité dat Nederland niet heeft gespecificeerd onder welke omstandigheden van het koppelingsbeginsel kan worden afgeweken. Liet het EHRM de beoordeling hiervan bij het nationale bestuursorgaan en de nationale rechter, het Comité is kennelijk van oordeel dat de Nederlandse Staat dient te specificeren onder welke omstandigheden afwijking is gerechtvaardigd.

Resumerend kan worden gesteld dat het in het koppelingsbeginsel gemaakte onderscheid naar nationaliteit en verblijfsstatus volgens vaste jurisprudentie van de hoogste rechtscolleges in beginsel niet in strijd wordt geacht met de internationale discriminatieverboden. Alleen in zeer bijzondere omstandigheden hoeft van het beginsel te worden afgeweken op grond van het discriminatieverbod. Beroep op strijd met overige materiële internationale normen is meer succesvol gebleken voor het buiten toepassing laten verklaren van het koppelingsbeginsel dan het meer formele beroep op de artikelen 26 IVBPR en 14 EVRM.

\subsubsection{Beroep op overige internationale normen}

\subsubsection{Bijstand}

Het recht op gezondheid (artikel 12 IVESCR) werd (onder meer) ingeroepen in een zaak over afwijzing van een bijstandsaanvraag van onrechtmatig verblijvende kinderen, die met hun ouders terug moesten naar Afghanistan. In deze zaak ging de Centrale Raad in op mogelijke strijd van het koppelingsbeginsel met diverse internationale bepalingen: artikelen 13 (recht op sociale en medische bijstand) en 17 (recht op bescherming kinderen) van het ESH en de artikelen 9 (recht op sociale zekerheid), 11 (recht op behoorlijke levensstandaard) en artikel 12 IVESCR. Volgens de Centrale Raad hebben deze bepalingen geen rechtstreekse werking:

"Naar het oordeel van de Centrale Raad is in genoemde verdragsartikelen sprake van algemeen omschreven sociale doelstellingen waaruit geen onvoorwaardelijk en nauwkeurig bepaalbaar subjectief recht in de vorm van een (afdwingbare) aanspraak op bijstand valt te ontlenen."30

In dit geval achtte de Centrale Raad de 'fair balance' tussen de publieke belangen en de particuliere belangen van betrokkenen voldoende afgewogen. Volgens de Raad was de gevraagde verstrekking van medische zorg aan niet-legaal in een verdragsstaat verblijvende personen niet uitgesloten.

\subsubsection{Onderdak/opvang}

Het duurde tot 2010 voor de Centrale Raad het koppelingsbeginsel opzij zette met toepassing van artikel 8 EVRM. Dit gebeurde in twee zaken die betrekking hadden op het recht op opvang in het kader van de Wmo. ${ }^{31}$ Het ging in deze zaken om rechtmatig verblijvende vreemdelingen

en niet direct aan de dochter, heeft de weigering van een kindgebonden budget volgens het Comité wel direct gevolgen voor het welzijn van de dochter.

${ }^{30}$ CRvB 22 december 2008, ECLI:NL:CRVB:2008:BG8789, JV 2009/99, m.nt. Minderhoud en Slingenberg, r.o. 4.4.

${ }^{31}$ CRvB 19 april 2010, ECLI:NL:CRVB: 2010:BM0956, JV 2010/291, m.nt. P.E. Minderhoud en CRvB 19 april 2010, ECLI:NL:CRVB:2010:BM1992, JV 2010/292, m.nt. P.E. Minderhoud. Het ECSR oordeelde eerder (2009) 
die waren uitgesloten van opvang. In één zaak ging het om een vreemdeling met psychiatrische voorgeschiedenis die tot de categorie van kwetsbare personen behoorde die in het kader van artikel 8 EVRM in het bijzonder recht hebben op bescherming van hun privé- en gezinsleven. ${ }^{32}$ Er was volgens de Raad sprake van een zodanige aantasting van de 'very essence' van artikel 8 EVRM dat er een positieve verplichting op de staat berust om te voorzien in een voor appellant adequate opvang.

De Hoge Raad had in 2012 te oordelen over de vraag of de Staat diende te voorzien in de opvang van uitgeprocedeerde minderjarigen indien hun ouders niet meewerken aan uitzetting. Op de Staat rust de verplichting te waken voor de rechten en belangen van minderjarigen die zich op zijn grondgebied bevinden, ook waar het gaat om minderjarige vreemdelingen zonder geldige verblijfstitel, mede omdat zij niet verantwoordelijk kunnen worden gehouden voor gedragingen van hun familieleden. De Hoge Raad onderbouwde dit met de rechtspraak van het EHRM, de aan de Opvangrichtlijn en de TRi ten grondslag liggende beginselen en het op grond van het ESH ingenomen standpunt van het ECSR en Comité van Ministers. ${ }^{33}$ Op de Staat rust dan ook (in dit geval) volgens de Hoge Raad de rechtsplicht om voor de kinderen in adequate opvang en verzorging te voorzien. ${ }^{34}$

Ten aanzien van toelating tot maatschappelijke opvang (Wmo) wordt weigering van opvang jegens minderjarige kinderen in sommige gevallen niet in overeenstemming met de krachtens artikel 8 EVRM vereiste 'fair balance' tussen publieke en particuliere belangen geacht. ${ }^{35}$ Voor overige kwetsbare personen (volwassenen) is de rechter terughoudender en blijft de toegang tot Wmo-voorzieningen voor onrechtmatig verblijvende vreemdelingen beperkt tot absolute noodsituaties. ${ }^{36}$

Gebrek aan opvang kan tot schade aan de gezondheid lijden. Dit was aan de orde in een casus waarbij het ging om een Egyptische man die al sinds 1978 in Nederland verbleef zonder verblijfsvergunning. Zijn (nieuwe) verzoek om toegelaten te worden tot voor ouderen geschikte maatschappelijke opvang als bedoeld in de Wmo werd afgewezen. ${ }^{37}$ Hangende het hoger beroep tegen een uitspraak van de rechtbank deed verzoeker een verzoek om een voorlopige voorziening. Verzoeker was depressief en had diverse lichamelijke klachten die voortvloeiden uit een verminderd werkende hartspier, een vergrote lever, diabetes, ontstoken voeten/onderbenen en galstenen. Volgens de huisarts was geleidelijk niet alleen een bedreigde voet, maar een bedreigd been ontstaan. De voeten van verzoeker waren door neuropathie in combinatie met slecht schoeisel al meer bedreigd dan bij verzekerden die niet dakloos zouden zijn. De infecties werden - mede door gebrek aan opvang - omvangrijker en moeilijker te behandelen. Eerder achtte de Centrale Raad geen schending van de artikelen 3 en 8 EVRM aanwezig, aangezien (onder meer) verzoeker kon terugkeren naar Egypte en niet gebleken was

\footnotetext{
dat Nederland in strijd handelde met het ESH(herzien) door niet rechtmatig in Nederland verblijvende kinderen geen onderdak te verlenen (Defence for Children/Nederland), zie ook par. 6.6.2.1 van dit proefschrift.

${ }^{32}$ CRvB 19 april 2010, JV 2010/292, m.nt. P.E. Minderhoud.

${ }^{33}$ Resolution CM/ResChS(2010)6, no. 47/2008, r.o. 3.7.2.

${ }^{34}$ HR 21 september 2012, ECLI:NL:HR:2012:BW5328, JV 2012/458, m.nt. C.H. Slingenberg.

35 Zie bijvoorbeeld CRvB 30 mei 2011, ECLI:NL:CRVB:2011PBQ6438, RSV 2011/232, m.nt. C.W.A.C. Bruggeman.

${ }^{36}$ A.C. Hendriks, annotatie bij: CRvB 11 mei 2012, ECLI:NL:CRVB:2012:BW6227, GJ 2012/115, nr. 6.

${ }^{37}$ Het beroep tegen het afwijzende besluit op de eerste aanvraag was door de rechtbank reeds ongegrond verklaard, welke uitspraak door de CRvB was bevestigd (CRvB 18 april 2012, LJN BW3240).
} 
van een geldige belemmering die daaraan in de weg stond. Niet kon worden gezegd dat de fysieke en psychische gezondheid van verzoeker substantieel werd bedreigd wanneer hij verstoken bleef van maatschappelijke opvang. ${ }^{38}$ De Centrale Raad merkte verzoeker daarom niet aan als kwetsbaar persoon voor wie de Staat op grond van artikel 8 EVRM een positieve verplichting heeft om te voorzien in diens opvang, ook niet in samenhang bezien met zijn leeftijd. De Raad was eerder van oordeel dat het beroep op artikel 3 EVRM geen doel trof, omdat dit artikel een veel zwaardere norm stelt dan artikel 8 EVRM. De voorzieningenrechter sloot zich bij dit oordeel aan. Van belang is voorts dat de voorzieningenrechter meewoog dat de noodzakelijke medische voorzieningen beschikbaar waren via de bijdrageregeling ex artikel 122a Zvw. Zou gedurende een extramurale medische behandeling, of zonder een dergelijke behandeling, sprake zijn van medisch noodzakelijke opvang, dan zou verzoeker een beroep kunnen doen op het college van B\&W om daarin te voorzien in het kader van een ziekenboegbed-indicatie. Ook wees de voorzieningenrechter er op dat voor zover sprake was van een levensbedreigende situatie, verzoeker zich voor behandeling kon wenden tot zorgverleners. ${ }^{39}$

Deze uitspraak laat zien dat er verschillend kan worden gedacht over het kwalificeren van 'kwetsbare personen'. Hendriks vraagt zich in zijn annotatie mijns inziens terecht af hoeveel erger het moet worden voordat het weigeren van een sociale voorziening - in dit geval maatschappelijke opvang - de menselijke waardigheid van de betrokkene in de kern aantast. Volgens hem had deze man aangemerkt kunnen worden als 'kwetsbaar persoon'. ${ }^{40}$ Daarnaast heeft de rechter in deze zaak naar mijn mening ten onrechte een toets aan artikel 3 EVRM nagelaten. In uitzettingszaken zien we immers een omgekeerde toets: eerst wordt gekeken naar mogelijke schending van artikel 3 EVRM (waarbij de drempel voor schending inderdaad hoog ligt) en voorts, als schending van artikel 3 EVRM niet aanwezig wordt geacht, naar artikel 8 EVRM.

Sinds 2015 oordeelt de Centrale Raad niet langer over zaken die betrekking hebben op de opvang van onrechtmatig verblijvende vreemdelingen, aangezien de Centrale Raad oordeelde dat de geboden opvangvoorzieningen niet langer zouden worden aangemerkt als maatschappelijke opvang op grond van de Wmo. ${ }^{41}$ De Centrale Raad merkt de opvang in een VBL in het algemeen als een voldoende voorziening in het bieden van opvang. ${ }^{42}$

\subsubsection{Zorgverzekeringswetten}

Wat betreft aanspraken op medische zorg kwam de doorbraak in 2010, toen de Centrale Raad met een beroep op artikel 8 EVRM het in het AWBZ neergelegde koppelingsbeginsel doorbrak. ${ }^{43}$ De zaak betrof een kind met een autistische stoornis en een verstandelijke beperking. In afwachting van bezwaar tegen een verblijfsvergunning verbleef het kind rechtmatig in Nederland. De vraag was of het kind recht had op de uitgebreide zorg die het CIZ had geïndiceerd. De zorgverzekeraar wilde deze extra zorg (onder andere activerende en

\footnotetext{
${ }^{38}$ CRvB 18 april 2012, 11-4399 WMO, ECLI:NL:CRVB:2012:BW3240.

${ }^{39}$ CRvB (vzr.) 11 mei 2012, ECLI:NL:CRVB:2012:BW6227, GJ 2012/115, m.nt. A.C. Hendriks, ro. 3.3.

${ }^{40}$ A.C. Hendriks, annotatie bij: CRVB 11 mei 2012, ECLI:NL:CRVB:2012:BW6227, GJ 2012/115, nr. 5.

41 CRvB 26 november 2015, ECLI:NL:CRVB:2015:3834, JV 2016/19; ECLI:NL:CRVB:2015:3803; en ECLI:NL:CRVB:2015:4093.

${ }^{42}$ CRvB 22 januari 2017, ECLI:NL:CRVB:2017:626.

${ }^{43}$ CRvB 20 oktober 2010, ECLI:NL:CRVB:2010:B03581, JV 2011/90, m.nt. P.E. Minderhoud.
} 
ondersteunende begeleiding gedurende een groot aantal dagdelen per week) niet vergoeden, aangezien het kind was uitgesloten van het in artikel 5 en $5 \mathrm{~b}$ AWBZ neergelegde koppelingsbeginsel. Het onthouden van de geïndiceerde zorg aan het kind had volgens de Centrale Raad tot gevolg dat de persoonlijke ontwikkeling van het kind onmogelijk zou worden gemaakt, waardoor hij in het behoud van zijn menselijke waardigheid ernstig werd bedreigd. Mede bezien in het licht van het IVRK kon volgens de Centrale Raad niet in redelijkheid worden volgehouden dat de weigering van deze zorg blijk gaf van een 'fair balance' tussen de publieke belangen, die betrokken zijn bij de weigering van die zorg, en de particuliere belangen van het kind om die zorg te ontvangen. Op de zorgverzekeraar rustte de positieve verplichting om te voorzien in de voor het kind noodzakelijk geachte zorg.

In 2011 kende de voorzieningenrechter van de Centrale Raad het recht op AWBZ-zorg toe aan een niet rechtmatig in Nederland verblijvende vreemdeling die ongewenst was verklaard. ${ }^{44}$ In deze zaak ging het om een psychotische en schizofrene volwassen man die door de Centrale Raad als kwetsbaar persoon werd aangemerkt. Het onthouden van de effectuering van het geïndiceerde zorgzwaartepakket was voor hem levensbedreigend. Bij zijn overweging over het beroep van verzoeker op artikel 8 EVRM, stelde de Centrale Raad (evenals in soortgelijke zaken) voorop dat het respect voor menselijke waardigheid en menselijke vrijheid door het EHRM als de 'very essence' van het EVRM wordt aangemerkt. De 'fair balance' afweging (de afweging tussen de publieke belangen die betrokken zijn bij de weigering van zorg en de particuliere belangen van de vreemdeling) resulteerde in dit geval in een positieve verplichting van het zorgkantoor om te voorzien in de voor de verzoeker noodzakelijk geachte zorg. ${ }^{45}$

Artikel 122a Zvw speelde tot 2012 bij de beoordeling van dit soort zaken geen significante rol. Volgens de Centrale Raad zag dit artikel immers niet op het behartigen van zorgbelangen van vreemdelingen als verzoeker, maar slechts op de inkomensderving van zorgaanbieders bij het verlenen van zorg aan de in dat artikel genoemde vreemdelingen. ${ }^{46}$ Sinds 2012 is sprake van een nieuwe koers in de jurisprudentie en acht de Centrale Raad artikel 122a Zvw wel van belang voor de beoordeling van een beroep op artikel 8 EVRM. ${ }^{47}$ De Centrale Raad stelde in deze zaak voorop dat het koppelingsbeginsel de toegang van vreemdelingen tot de openbare gezondheidszorg ongeacht hun verblijfspositie geheel onverlet laat. De bekostiging van deze in beginsel toegankelijke zorg zou een belemmering kunnen vormen. Met de bijdrageregeling heeft de wetgever beoogd medisch noodzakelijke zorg voor vreemdelingen toegankelijk te maken.

"De Staat heeft derhalve uitdrukkelijk gekozen om ter invulling van de verplichtingen die onder meer voortvloeien uit artikel 8 van het EVRM het in rechtsoverweging 4.2.4 omschreven vergoedingsstelsel van artikel 122a van de Zvw te introduceren. Niet gebleken is dat dit systeem in zijn algemeenheid de toegankelijkheid van medisch noodzakelijke zorg aan de hier bedoelde doelgroep niet faciliteert. Uit het rapport van Berenschot "Evaluatie van de bijdrageregeling van

\footnotetext{
${ }^{44}$ CRvB 9 september 2011, ECLI:NL:CRVB:2011:BT1738, nr. 11/4654 AWBZ/VV, RSV 2011/336.

${ }^{45}$ CRvB 9 september 2011, ECLI:NL:CRVB:2011:BT1738, nr. 11/4654 AWBZ/VV, RSV 2011/336, r.o. 4.10.

${ }^{46}$ CRvB 9 september 2011, ECLI:NL:CRVB:2011:BT1738, RSV 2011/336, r.o. 4.12.

${ }^{47}$ CRvB 6 juni 2012, ECLI:NL:CRVB:2012:BW7703, RZA 2012/49, m.nt. C.W.C.A. Bruggeman. Zie ook CRvB 4 juni 2014, ECLI:NL:CRVB:2014:2043 en CRVB 1 februari 2017, ECLI:NL:CRVB:2017:492, USZ 2017/113, RSV 2017/7.
} 
artikel 122a van de Zorgverzekeringswet" van 7 november 2011 blijkt dat CVZ in april 2011 met 27 AWBZ-instellingen en 40 GGZ-instellingen had gecontracteerd, en dat de Inspectie voor de volksgezondheid nauwelijks tot geen signalen had ontvangen dat de toegankelijkheid van de zorg in het geding is (p. 16 en 18). Deze door de Staat gemaakte keuze valt binnen de ruime "margin of appreciation" die de Staat toekomt waar het gaat om de besteding van publieke middelen". 48

De toets, die de rechter vervolgens uitvoert, is of de weigering om de zorg te verlenen de normale ontwikkeling van het privéleven van de vreemdeling onmogelijk maakt. Die drempel ligt hoog. Volgens de Centrale Raad dient de vreemdeling zich zelf tot de zorgaanbieder te wenden. Indien deze geen zorg verleent, kan de vreemdeling de 'daarvoor geëigende procedure volgen om de zorg alsnog te ontvangen'. ${ }^{49}$

Deze redenering van de Centrale Raad ligt in de lijn van de opvatting van Hallie inhoudende dat de toegang tot zorg ook buiten de zorgverzekeringswetten om geregeld kan worden. ${ }^{50}$ De Centrale Raad is van oordeel dat de toegang tot zorg feitelijk is gewaarborgd. Met artikel 122a Zvw is automatisch voldaan aan de artikel 8 EVRM-toets. Het feit dat een vreemdeling zich rechtstreeks kan wenden tot een zorgverlener is voldoende om geen schending van artikel $8 \mathrm{EVRM}$ aan te nemen. Kritisch hierover is Bruggeman. Hij is van mening dat artikel 122a Zvw niet altijd een oplossing kan bieden voor de te bieden noodzakelijke zorg. Volgens hem dient per individueel geval te worden bekeken of de bijdrageregeling als alternatief voor een beroep op artikel 8 EVRM volstaat, mede gelet op de hogere juridische status van artikel 8 EVRM. ${ }^{51}$ Ik sluit mij bij Bruggeman aan. Naast het door Bruggeman genoemde argument, betekent het feit dat is voldaan aan de artikel 8 EVRM-toets niet automatisch dat is voldaan aan de overige mensenrechtentoetsen zoals vastgelegd in artikel 3 EVRM. Daar gaat de Centrale Raad met de hierboven geciteerde redenering aan voorbij..$^{52}$ Daarnaast kent de toegang tot zorg voor de vreemdeling (nog steeds) drempels. Zo vergoedt de bijdrageregeling niet alle medisch noodzakelijke zorg en zijn niet alle zorgverleners bekend met de regeling, waardoor medisch noodzakelijke zorg kan worden geweigerd en de feitelijke toegang dus wordt beperkt. ${ }^{53}$ Juist in individuele gevallen waarin de bijdrageregeling niet toereikend is voor de toegankelijkheid van zorg, dient er een mensenrechtentoets te kunnen plaatsvinden. Bovendien is tegen de opvatting van de Centrale Raad in te brengen dat Nederland het Biogeneeskundeverdrag niet heeft geratificeerd, omdat (onder meer) de uitzondering op de Koppelingswet ('medisch nood-

\footnotetext{
${ }^{48}$ CRvB 6 juni 2012, ECLI:NL:CRVB:2012:BW7703, RZA 2012/49, m.nt. C.W.C.A. Bruggeman, r.o. 4.2.5.

${ }^{49}$ CRvB 4 juni 2014, ECLI:NL:CRVB:2014:2043, r.o. 4.6. In deze zaak voerde appellant aan dat er op dit moment geen bestuursorgaan is waarmee gediscussieerd kan worden over de hoogte van de benodigde zorg, de toewijzing en de toegankelijkheid van zorg. Aangevoerd werd dat feitelijk onmogelijk werd gemaakt te toetsen of de mensenrechten van appellant gewaarborgd bleven. In deze zaak oordeelde de Raad dat niet kon worden geoordeeld dat door de weigering van het zorgkantoor om de geïndiceerde zorg te realiseren, de normale ontwikkeling van het privéleven van appellant onmogelijk werd gemaakt.

${ }^{50}$ Reeds besproken in par. 4.4.2.

${ }^{51}$ Bruggeman, annotatie bij: CRvB 6 juni 2012, ECLI:NL:CRVB:2012:BW7703, RZA 2012/49.

${ }^{52}$ Daar komt nog bij dat de Centrale Raad de evaluatie van art. 122a uit 2011 alsmede het feit dat de IGZ nauwelijks tot geen signalen heeft ontvangen dat de toegankelijkheid van zorg in het geding is, als uitgangspunt neemt. Er zijn echter ook andere signalen, namelijk dat de feitelijke toegang wel in het geding is (zie hoofdstuk 9).

${ }^{53}$ Zie ook hoofdstukken 2 en 9 van dit proefschrift.
} 
zakelijke zorg') mogelijk niet zou voldoen aan het recht op gelijke toegang tot zorg. ${ }^{54}$ De Centrale Raad is echter niet gevoelig gebleken voor het argument dat de toegang tot medische zorg door onwelwillende zorgaanbieders wel in het geding is en dat deze belemmering in strijd kan komen met het internationale recht. ${ }^{55}$

\subsection{Naar een laagdrempelige rechtsgang}

Uitgangspunt is dus dat de vreemdeling zich rechtstreeks tot de zorgaanbieder dient te wenden en deze dient aan te spreken bij weigering van zorg. Dat kan toch bezwaarlijk van de vreemdeling worden verwacht. Deze zal wellicht zorg gaan mijden of zich neerleggen bij de weigering. Bovendien suggereert het dat de vreemdeling (en/of diens verwijzer) op de hoogte is van door het CAK gecontracteerde instellingen. Komt hij in een niet gecontracteerde instelling terecht, dan zal de zorg al op voorhand kunnen worden geweigerd. Voor kinderen geldt dan nog als extra drempel dat hun ouders deze gang naar de rechter dienen te maken. Het handhaven van rechten als het recht op medisch noodzakelijke zorg is moeilijk. ${ }^{56}$ Daarmee is de norm (het recht op gezondheidszorg) achter de horizon verstopt en heeft het geen of minder betekenis. De vreemdeling zou deze norm op laagdrempelige wijze moeten kunnen inroepen. Dit zou ook meer recht doen aan de verantwoordelijkheid van de overheid, die volgens Straatsburgse jurisprudentie verantwoordelijk is als zorgaanbieders onvoldoende doen ter bescherming van het leven van patiënten (Mehmet Şentürk en Bekir Şentürk/Turkije). ${ }^{57}$ Ook op grond van de beginselen van het gezondheidsrecht is een extra bescherming van deze groep mensen aangewezen. Het beschermingsbeginsel dient de gezondheid van mensen te beschermen en bevorderen, in het bijzonder die van kwetsbare mensen. ${ }^{58}$ Adequate procedurele rechtsbescherming is onontbeerlijk om het recht op medisch noodzakelijke zorg te effectueren.

Op grond van bovenstaande overwegingen is mijn voorstel om een adviescommissie in het leven te roepen voor gevallen waarin een niet rechtmatig verblijvende vreemdeling een beroep doet op een indicatie/vergoeding van zorg op grond van (zeer) bijzondere omstandigheden. Een specifieke laagdrempelige rechtsgang past immers bij het recht op gezondheidszorg. Zo is de geschillenregeling ex de Wet kwaliteit, klachten en geschillen zorg (Wkkgz) in het leven geroepen omdat veel mensen de gang naar de rechter als een te hoge drempel ervaren. ${ }^{59}$ Van de (zieke) vreemdeling wordt dit wel verwacht. Dit kan in strijd worden geacht met het gelijkheidsbeginsel.

De adviescommissie zou kunnen bestaan uit een jurist, een ethicus en een arts. Doel van de commissie is om te oordelen over de vraag of het niet vergoeden van zorg tot schending van

\footnotetext{
${ }^{54}$ RvS 11 april 2000, W13.00.0053/III/K, Bijvoegsel Stcrt. 2004, 47. Zie par. 6.5.3.

${ }^{55}$ CRvB 1 februari 2017, ECLI:NL:CRVB:2017:492, USZ 2017/113. In deze zaak oordeelde de Centrale Raad dat het CIZ terecht heeft geweigerd aan appellante een indicatie voor zorg als bedoeld in de Wlz te verlenen omdat zij geen rechtmatig verblijf had.

${ }^{56}$ Dit geldt ook buiten de gezondheidszorg. Eerder pleitte Minderhoud ervoor dat uitvoeringsinstanties zelf de wettelijke mogelijkheid zouden moeten krijgen om het koppelingsbeginsel buiten werking te stellen voor alle personen die naar hun oordeel in een kwetsbare situatie verkeren. Zijn voorstel was om een wettelijk kader te creëren teneinde te voorkomen dat in ieder individueel geval de rechter steeds moet worden ingeschakeld, Minderhoud, NTM/NJCM-Bull. 2012/4, p. 391-407.

${ }^{57}$ Zie par. 6.5.1.1 van dit proefschrift.

${ }^{58}$ Leenen e.a. 2017, p. 60.

${ }^{59}$ Art. 13 Wkkgz.
} 
een mensenrecht kan leiden, in de vorm van een bindend advies voor de uitvoerende instantie. Dit scheelt de vreemdeling een lange gang naar de rechter en garandeert meer uniformiteit over de uitleg van open normen als 'ontwikkeling', 'onmenselijk' en 'strijd met menselijke waardigheid'. Een dergelijke commissie dient te voldoen aan eisen van artikel 6 EVRM. Naast onafhankelijkheid en onpartijdigheid, vloeien uit artikel 6 EVRM eisen voort zoals hoor- en wederhoor, toegang van partijen tot alle processtukken en adequate motivering van de uitspraak. Wellicht dienen met een laagdrempelige commissie wel wat concessies te worden gedaan. In hoger beroep bijvoorbeeld kan de rechter het (juridisch bindende) oordeel uitsluitend marginaal toetsen. Naar mijn mening gaat het er echter om dat de norm op een toegankelijke manier kan worden ingeroepen. Aansluiting kan worden gezocht bij de werkstijl van het CIZ, die bij de indicatiestelling voor langdurige zorg bij het juridisch oordeel een medisch oordeel betrekt of kan betrekken. Deze persoonlijke benadering doet recht aan de individuele zorgbehoeften van de vreemdeling. Het garanderen van een goede mentale en fysieke gezondheid is bovendien niet alleen in het belang van de vreemdeling zelf, het helpt ook om hem voor te bereiden op mogelijke terugkeer naar het land van herkomst. ${ }^{60}$ Het bieden van zorg is dus niet per definitie in strijd met de vertrekplicht van de vreemdeling. Het voorstel sluit ook aan bij het oordeel van de ACVZ inhoudende dat in ieder individueel geval een zorgvuldige belangenafweging dient te worden gemaakt om de menselijke waardigheid te garanderen. ${ }^{61}$

\subsection{Conclusie}

Het koppelingsbeginsel is een ferm uitgangspunt dat door de hoogste rechter in beginsel in overeenstemming met het internationale recht is geacht. De wijze waarop de hoogste bestuursrechter het koppelingsbeginsel toetst aan de artikelen 8 en 14 EVRM is door het EHRM geaccordeerd. Bij economische of sociale beleidskeuzes kan vanwege de ruime reikwijdte van de 'margin of apprecation' rekening worden gehouden met de al dan niet legale status van de betrokkene. Alleen in zeer bijzondere omstandigheden behoeft te worden afgeweken van het koppelingsbeginsel. De vreemdeling blijft echter in het ongewisse wanneer van dergelijke omstandigheden sprake kan zijn, aangezien de rechter deze omstandigheden niet nader heeft gespecificeerd.

Het koppelingsbeginsel is al met al geen keihard uitgangspunt maar kent zijn begrenzingen in de mensenrechten. Deze begrenzingen zijn voor de onrechtmatig verblijvende vreemdeling echter lastig tot vrijwel onmogelijk in te roepen. In sommige zaken lijkt de ondergrens van menselijke waardigheid al te zijn bereikt.

De bijdrageregeling geeft volgens vaste jurisprudentie invulling aan de internationale verdragen. Daarmee is het systeem van de indirecte uitzondering op het koppelingsbeginsel in zijn algemeenheid aanvaard. Dit sluit echter niet uit dat er individuele gevallen bestaan die buiten het vangnet van de mensenrechten vallen en daardoor geen of onvoldoende zorg ontvangen. Voor deze individuele gevallen dient vanuit het licht van de gezondheidsrechtelijke

\footnotetext{
${ }^{60}$ Pro Facto 2018, p. 79.

${ }^{61}$ ACVZ 2012, p. 11. De ACVZ achtte strikte toepassing van het koppelingsbeginsel op gespannen voet staan met Europees in internationaal recht.
} 
rechtsbeginselen een laagdrempelige rechtsgang te worden gecreëerd zodat de norm (het recht op gezondheid) op een toegankelijke manier kan worden ingeroepen. 


\title{
Hoofdstuk 9 Toegang tot de gezondheidszorg ${ }^{1}$
}

\author{
Fajar James, die acht jaar onrechtmatig in \\ Nederland verblijft, is in Sierra Leone gewond \\ geraakt door een kapmes. Hij heeft na een eerdere \\ operatie ernstige wildgroei in zijn nek waarvan hij \\ veel pijn ondervindt. James had een afspraak om \\ een serie operaties te ondergaan bij de plastisch \\ chirurg. Toen werd hij opgepakt en kwam hij in een \\ detentiecentrum terecht. Hij mocht gedurende zijn \\ detentie niet naar het ziekenhuis. De operaties \\ gingen niet door en zijn klachten verergerden. \\ James: "Om in de taal van mijn land te spreken: ik \\ voel me een kakkerlak. In het land van kippen heeft \\ een kakkerlak geen macht."
}

Bron: Zembla, 'Onderduiken met illegalen'.

\subsection{Inleiding}

Dit hoofdstuk neemt voorbij het individuele geval het systeem in zijn geheel onder de loep. Onderzocht wordt in hoeverre hier algemene tekortkomingen te identificeren zijn. In hoofdstuk twee zagen we al dat er praktische (informele) barrières bestaan die zieke vreemdelingen kunnen ondervinden met betrekking tot (de toegang tot) de medische zorg. Dit hoofdstuk ziet op de formele barrières. Dit zijn drempels die voortvloeien uit het door de wetgever gekozen systeem (uitsluiting van ziektekostenverzekeringen en financiering van medisch noodzakelijke zorg). Drempels in de zorg, waaronder financiële, kunnen leiden tot onvoldoende waarborg van de feitelijke toegankelijkheid van de zorg. Dit hoofdstuk beoogt dan ook antwoord te geven op deelvraag vier: Hoe werkt het gekozen systeem in de praktijk en welke knelpunten doen zich voor met betrekking tot (toegang tot) de zorgverlening aan ongedocumenteerden (formele drempels), met name aan kwetsbare groepen?

Het hoofdstuk vangt aan met een korte bespreking van het begrip toegankelijkheid van zorg. Daarna volgt een bespreking van diverse onderzoeken die zijn verricht naar de werking van de financieringsregelingen in de praktijk. Voorts wordt ingezoomd op een aantal specifieke knelpunten. Daarna wordt de toegang tot zorg van een aantal kwetsbare groepen besproken, met de nadruk op kinderen. Het hoofdstuk sluit af met een conclusie waarin verbeterpunten worden genoemd om de formele barrières zoveel mogelijk weg te nemen.

\footnotetext{
${ }^{1}$ Dit hoofdstuk bevat geüpdatete passages van Derckx TvGR 2017/2, p. 121-134, Derckx 2018 en Derckx \& Bloemen, $M C 2020 / 9$, p. 18-21.
} 


\section{2 (Financiële) toegankelijkheid}

Zoals aan de orde kwam in paragraaf 6.2.6.1, kent toegankelijkheid vier aspecten: financiële, geografische, tijdige en culturele toegankelijkheid. ${ }^{2}$ Mackenbach \& Stronks beschrijven toegankelijkheid als 'een situatie waarin eenieder die behoefte heeft aan zorg, feitelijk gebruik kan maken van deze zorg, binnen een redelijke termijn en tegen redelijke kosten'. ${ }^{3}$ Gelijke toegankelijkheid houdt in dat uitsluitend de zorgbehoefte het gebruik van zorg bepaalt en niet bijvoorbeeld financiële koopkracht. Financiële toegankelijkheid houdt mede in dat er geen financiële belemmeringen zijn om van aangeboden zorg gebruik te maken. Als deze belemmeringen er wel zijn, dat kan degene die zorg nodig heeft daarvan afzien of het gebruik uitstellen. Dit kan leiden tot verergering van de gezondheidsklachten of uiteindelijk tot hogere kosten. ${ }^{4}$ Financiële toegankelijkheid is dan ook elementair voor de waarborging van het recht op gezondheid. Het behoort tot de taak van de overheid om de financiële toegankelijkheid van noodzakelijke zorg te garanderen. Dit geschiedt op basis van solidariteit tussen mensen met verschillende gezondheidsrisico's respectievelijk verschillende financiële middelen. ${ }^{5}$ In het systeem van de waarborging van het recht op gezondheid van de onrechtmatig verblijvende vreemdeling is het uitgangspunt dat de feitelijke toegang tot zorg is gegarandeerd en dat de financiële drempels deze feitelijke toegang niet in de weg staan, hetgeen is geaccordeerd in de rechtspraak. Hieronder zal blijken dat dit uitgangspunt niet altijd opgaat.

\subsection{De werking van de financieringsregeling in de praktijk}

In diverse evaluatieonderzoeken over de financieringsregeling zijn de elementen toegankelijkheid en financiering van zorg separaat onderzocht.

\subsubsection{Vóór invoering artikel 122a Zvw (de Regeling Stichting Koppeling)}

In het kader van de evaluatie van de Koppelingswet, hebben rond de eeuwwisseling twee onderzoeken plaatsgevonden. Het Nivel onderzocht in 1999 de toegankelijkheid van zorg van illegalen en TNO deed in 2001 onderzoek naar de financiering van zorg voor illegalen. ${ }^{6}$ Dat was nog onder het régime van het Koppelingsfonds.

Alhoewel het Nivel concludeerde dat de toegankelijkheid tot de eerstelijns gezondheidszorg voor illegalen redelijk leek, constateerde het wel problemen die hulpverleners ervoeren in de zorg voor illegalen. Communicatieproblemen, problemen bij doorverwijzing en de financiële problematiek leken het belangrijkst. ${ }^{7}$ Toenmalig minister van VWS leidde hieruit af dat de sombere verwachtingen over het Koppelingsfonds niet bewaarheid waren geworden. ${ }^{8}$ 'Het feit dat tot op heden geen incident met voor de patiënt fatale afloop is gemeld illustreert wel dat arts en hulpverlener nog steeds op de eerste plaats zorg verlenen en daarna pas kijken

\footnotetext{
${ }^{2}$ Zie ook UN Committee on Economic, Social and Cultural Rights, General comment no 14: The Right to the Highest Attainable Standard of Health (art. 12), 22nd Sess, UN Doc E/C/.12/2000/4 (11 August 2000).

${ }^{3}$ Mackenbach \& Stronks 2016, p. 326.

${ }^{4}$ Mackenbach \& Stronks 2016, p. 376.

${ }^{5}$ Leenen 2017, p. 42.

${ }^{6}$ Nivel 1999 en TNO 2001.

${ }^{7}$ Nivel 1999, p. 74, TNO Preventie en Gezondheid 2001.

${ }^{8}$ Brief van de Minister van VWS aan de Voorzitter van de Tweede Kamer, 1998/99, 19637 nr. 452 , p. 5.
} 
naar de financiële afwikkeling van de behandeling', aldus de minister. ${ }^{9}$

Ook uit het onderzoek van TNO bleek dat de beide financiële regelingen (de Stichting Koppeling en de regeling dubieuze debiteuren) geen drempels leken op te werpen die beperkend werken voor de toegankelijkheid van de zorg. Wel bleek dat voor beide regelingen de nodige creatieve oplossingen nodig waren, bij gebreke waarvan een knelpunt in de financiering van de zorg voor illegalen kon ontstaan. ${ }^{10}$

De verwevenheid van de financiering van noodzakelijke zorg en de feitelijke toegankelijkheid daarvan blijkt uit het feit dat TNO in dit onderzoek - dat slechts zag op de financiering - tevens conclusies trok over de toegankelijkheid van zorg. Het signaleerde dat de toegankelijkheid van met name de dure zorg (medicatie en diagnostiek), complexe zorg (bij chronisch zieken) en tweedelijns gezondheidszorg het meest onder druk stond. Daarnaast bleek dat het begrip medisch noodzakelijke zorg verschillend werd uitgelegd. Met name de ziekenhuizen in de grote steden hanteerden een strengere definitie dan de eerstelijnszorgverleners in de regio. Tot slot signaleerde TNO de concentratie van de zorgvraag (met name in de vier grote steden) als knelpunt in de toegankelijkheid van de zorg. Dit had tot gevolg dat veelal dezelfde zorgverleners, instellingen en zorgverzekeraars met de problematiek geconfronteerd werden. ${ }^{11}$

Tien jaar later voerde het Nivel een update uit van het onderzoek uit 1999. Aanleiding hiervoor was de herstructurering van het zorgstelsel en de (toentertijd aanstaande) invoering van de bijdrageregeling. ${ }^{12}$ In vergelijking met het onderzoek in 1999, leek de toegankelijkheid van de gezondheidszorg voor illegalen volgens zorgverleners te zijn verbeterd. Toch bleken er nog altijd knelpunten te zijn die deze toegankelijkheid beperkten. Het belangrijkste knelpunt in die toegankelijkheid werd nog altijd gevormd door de financiële eisen die zorgverleners stelden aan de hulpverlening aan illegalen. Een deel van de zorgverleners was niet op de hoogte van de mogelijkheden voor vergoeding van de kosten van verleende zorg aan illegalen. Gesignaleerd werd dat het nog altijd voorkwam dat zorgverleners om financiële redenen illegale patiënten weigeren of dat illegale patiënten afzien van verdere hulp. Deze financiële drempel zou volgens de onderzoekers echter grotendeels worden weggenomen door betere informatie over de regelgeving en vergoedingsmogelijkheden aan zowel zorgverleners als illegalen. Huisartsenzorg werd door belangenorganisaties als het meest toegankelijk ervaren. Voorlichting en informatieverspreiding bleken cruciaal voor het waarborgen van de toegankelijkheid van de gezondheidszorg voor illegalen in Nederland.

In het kader van onderzoek naar toegankelijkheid tot zorg vanuit een gelijkheidsperspectief (dat wil zeggen: gelijke toegang én gelijk gebruik van zorg bij gelijke behoefte mét een gelijke kwaliteit van zorg voor iedereen) concludeerde ook het RIVM dat de toegankelijkheid van de tweede lijn voor deze groep nog zorgelijk was. ${ }^{13}$ Deze conclusie was overigens (uitsluitend) gestoeld op het rapport van het Nivel.

9.3.2 Na invoering artikel 122a Zvw (de bijdrageregeling)

\footnotetext{
${ }^{9}$ Ibid. p. 4.

10 TNO 2001, p. 10.

11 TNO 2001, p. 12.

12 Nivel 2009, p. 149-150. Onderzocht werden zowel de toegankelijkheid van de eerstelijnsgezondheidszorg als de gevolgen die zorgverleners verwachten van de nieuwe financieringsregeling.

${ }^{13}$ RIVM 2010, p. 128.
} 
De financieringsregeling van artikel 122a ZVW werd drie jaar na inwerkingtreding geëvalueerd door Berenschot. Geconcludeerd werd dat er ten aanzien van de toegankelijkheid een aantal aandachtspunten bestond. Zo bleek de mate van bereidheid om zorg te verlenen aan illegalen en andere onverzekerbare vreemdelingen te wisselen per type zorgaanbieder. Huisartsen toonden de meeste bereidheid. Daarnaast werd gesignaleerd dat de toegang tot zorg enerzijds afhankelijk was van de informatievoorziening die werd verleend aan illegalen en andere onverzekerbare vreemdelingen en anderzijds van de kennis en ervaring met de bijdrageregeling van medewerkers binnen zorginstellingen. Met name in de AWBZ-instellingen was dit merkbaar en meer specifiek binnen de GGZ. Uit documenten, gesprekken en de werkbijeenkomst bleek dat sprake was van onderbehandeling van GGZ problematiek bij illegalen en andere onverzekerbare vreemdelingen. ${ }^{14}$

Het criterium 'medisch noodzakelijke zorg' leverde volgens de evaluatie in de praktijk doorgaans geen problemen op. Sommige zorgvragen, die niet tot de zorg horen waarvoor de bijdrageregeling in het leven is geroepen, kunnen uitgroeien tot medisch noodzakelijke zorg. Preventieve zorg kan dan kostenbesparend zijn. ${ }^{15}$

Naar aanleiding van deze evaluatie stelde de Minister van VWS (opnieuw) vast dat de toegankelijkheid van zorg voldoende werd gewaarborgd. ${ }^{16}$ Deze conclusie was met name gestoeld op het feit dat de IGZ nauwelijks tot geen signalen had ontvangen dat de toegankelijkheid in het geding is.

Sindsdien is de bijdrageregeling niet meer in al haar merites geëvalueerd. Wel is de bijdrageregeling in 2018 geëvalueerd in relatie tot de bijdrage die ze levert aan de toegankelijkheid en betaalbaarheid van de zorg. De conclusie was dat gesteld kon worden dat het doel van de bijdrageregeling werd bereikt. Door het ontvangen van kwalitatief goede gezondheidszorg is de gezondheidstoestand van de vreemdeling verbeterd en heeft hij/zij op eenvoudige wijze toegang tot de zorg. Wel werd hierbij de kanttekening geplaatst dat het door het ontbreken van harde data moeilijk was uitspraken te doen over de verbeterde gezondheidstoestand van de vreemdeling en of de zorg breed toegankelijk was. Ook voldoet Nederland volgens deze beleidsdoorlichting met deze bijdrageregeling aan verplichtingen uit internationale verdragen. ${ }^{17}$

\subsubsection{Beroepsgeheim en discriminatie}

De KNMG achtte het onwenselijk dat een hulpverlener naar de verblijfsstatus van patiënten zou moeten vragen. Dit zou de vertrouwensrelatie tussen hulpverleners en patiënten kunnen schaden en tevens administratieve rompslomp veroorzaken. De regering was van mening dat de hulpverlener niet naar de verblijfsstatus zou hoeven te vragen. Wel dient de hulpverlener na te gaan of de patiënt verzekerd is. Vervolgens is het de fondsbeheerder die dient te verifiëren of de zorg is verleend aan illegaal verblijvende vreemdelingen. ${ }^{18}$ Dit standpunt is meerdere malen bevestigd. Kamerleden wezen erop dat een waterdicht inzicht in de verblijfsstatus snel

\footnotetext{
${ }^{14}$ Castelijns e.a. 2011, p. 29-30.

15 Castelijns e.a. 2011, p. 32.

${ }^{16}$ Brief van de Minister van VWS aan de Voorzitter van de Tweede Kamer, Z/VV-3095364, Den Haag: 8 december 2011.

${ }^{17}$ Beleidsdoorlichting VWS 2018, p. 26.

${ }^{18}$ Kamerstukken II 1995/96, 24 233, nr. 6, p. 58-59.
} 
op gespannen voet kan staan met het goed functioneren van hulpverleners. De toegankelijkheid van de gezondheidszorg zou hierdoor ernstig kunnen worden belemmerd. ${ }^{19}$

Voormalig minister van VWS Borst-Eilers benadrukte dat hulpverleners geen meldplicht hebben aan vreemdelingendiensten als zij illegaliteit vermoeden. Zij hebben beslist geen rol bij opsporing en uitwijzing van illegalen. ${ }^{20}$ Ook de KNMG en diverse beroepsorganisaties wijzen op het belang van het benadrukken van het beroepsgeheim bij zorgverlening aan ongedocumenteerden. ${ }^{21}$ Het belang van het beroepsgeheim voor de onbelemmerde toegang tot zorg is bij deze groep evident. Er zijn geen signalen dat er problemen zijn rond het beroepsgeheim. Dat is een positief punt, evenals de bevinding van Dokters van de Wereld dat discriminatie onder Nederlandse zorgverleners relatief weinig voorkomt vergeleken met andere Europese landen. ${ }^{22}$

\subsubsection{Fraudegevoeligheid}

Het is niet precies bekend hoe groot de doelgroep (het aantal onverzekerbare vreemdelingen) van de bijdrageregeling is. Volgens een veronderstelling waren er in 2016 circa 21.600 patiënten. ${ }^{23}$ Volgens Pharos vormt de groep uitgeprocedeerde asielzoekers maar een beperkt deel van de groep onverzekerbare vreemdelingen. ${ }^{24}$

De bijdrageregeling is op vertrouwen gebaseerd en daardoor fraudegevoelig. Zo zijn er signalen dat mensen die niet tot de doelgroep behoren zich als vreemdeling melden bij een zorgaanbieder. ${ }^{25}$ Vanwege de voor de toegang tot zorg noodzakelijk geachte anonimiteit is goede controle en opsporing van fraude lastig. Het ministerie van VWS onderzoekt welke maatregelen genomen kunnen worden om de bijdrageregeling meer fraudebestendig te maken. ${ }^{26}$

\subsubsection{Vijf-euro-maatregel}

Sinds 1 januari 2014 dient een onverzekerbare vreemdeling minimaal $€ 5$,- per receptregel aan eigen bijdrage te betalen aan de apotheker bij de uitgifte van de medicatie. Deze maatregel werd ingevoerd omdat bleek dat onverzekerbare vreemdelingen bij uitgifte van medicijnen niet of nauwelijks zelf de rekening betaalden, omdat zij niet bekend waren met het bestaan van de regeling. ${ }^{27}$ Naar aanleiding van signalen dat deze maatregel tot problemen zou kunnen leiden, is de maatregel voor onverzekerbare vreemdelingen met meervoudig en chronisch medicijn-

\footnotetext{
${ }^{19}$ Kamerstukken II 1996/97, 24 233, nr. 16, p. 8-9.

${ }^{20}$ Kamerstukken II 1999-2000, 19 637, nr. 505, p. 3.

21 Onder meer https://www.knmg.nl/actualiteit-opinie/nieuws/nieuwsbericht/zorg-voor-ongedocumenteerdemigranten-weet-u-hoe-het-zit.htm (laatst geraadpleegd 10 augustus 2020) en https://www.knov.nl/actueeloverzicht/nieuws-overzicht/detail/financieringsregeling-zorg-ongedocumenteerde-migranten-nu-via-cak/1862 (laatst geraadpleegd 11 mei 2020).

${ }^{22}$ Chauvin \& Simonnot 2012, p. 80.

${ }^{23}$ Het aantal is lastig na te gaan omdat er nauwelijks persoonsgegevens van de behandelde patiënten bekend zijn, alleen initialen en geboortejaar.

24 Pharos 2019 p. 9.

${ }^{25}$ In tegenstelling tot andere landen, kent Nederland geen legitimatieplicht.

${ }^{26}$ Beleidsdoorlichting VWS 2018, p. 24.

${ }^{27}$ Zorginstituut Nederland, 7e monitor Regeling financiering zorg onverzekerbare vreemdelingen, 24 mei 2013.
} 
gebruik op twee onderdelen verzacht. ${ }^{28}$ Volgens het ZiNL leidde de vijf-euro-maatregel niet tot een verminderde levering van geneesmiddelen aan onverzekerbare vreemdelingen. ${ }^{29}$ Veel gemeenten nemen deze kosten voor hun rekening. Deze maatregel lijkt te zijn ingevoerd onder het 'floodgate argument'. Er zijn geen signalen dat het recht op toegang tot essentiële medicijnen hiermee in het gedrang is gekomen. Een kleine wijziging in vergoedingsmogelijkheden hoeft niet direct in strijd te komen met het recht op gezondheidszorg.

\subsection{Knelpunten in de toegang tot zorg}

\subsubsection{Aanbevelingen Nationale ombudsman en 'Zorgeloos op straat'}

De Nationale ombudsman sprak zich in 2013 kritisch uit over de toegankelijkheid van zorg voor ongedocumenteerden. ${ }^{30}$ Deze concludeerde dat de toegang tot medische zorg voor ongedocumenteerden nog te veel drempels kende. Voor een goede toegang tot zorg is vereist dat de ongedocumenteerde zelfredzaam is en zorgverleners welwillend, wat volgens de Nationale ombudsman in de praktijk niet altijd de realiteit is. De kwetsbare positie van ongedocumenteerden staat deze zelfredzaamheid in de weg. Daarnaast staan ook zorgverleners niet altijd open voor zorg aan ongedocumenteerden. De Nationale ombudsman oordeelde daarnaast dat de minister van VWS onvoldoende zicht had op de toegang tot medische zorg voor ongedocumenteerden in de praktijk. Het beleid ten aanzien van de toegang tot zorg zou meer vanuit het perspectief van de ongedocumenteerden moeten worden gevoerd. Daarnaast zouden de mogelijkheden van preventie verkend moeten worden. De Nationale ombudsman deed een aantal aanbevelingen die de Staatssecretaris niet opvolgde. ${ }^{31}$ Deze aanbevelingen zijn naar mijn mening nog steeds actueel:

* Verstrek een CVZ-zorgpas aan ongedocumenteerden waarop staat vermeld dat zij recht hebben op medisch noodzakelijke zorg

* Organiseer een (telefonisch) informatiepunt voor ongedocumenteerden en degenen die hen bijstaan, voor vragen over de toegang tot of het recht op zorg.

* Monitor de daadwerkelijke toegang tot zorg. Zorg voor zicht op de aard en omvang van de zorgvragen van ongedocumenteerden.

* Inventariseer wat zorgverleners nodig hebben om drempels voor de zorg voor ongedocumenteerden weg te nemen en neem die drempels weg.

* Zorg dat er een instantie is die actief bemiddelt tussen ongedocumenteerden en zorgverleners als de ongedocumenteerde feitelijk problemen ondervindt bij de toegang tot medische zorg.

\footnotetext{
${ }^{28}$ 8e monitor Regeling financiering zorg onverzekerbare vreemdelingen, Zorginstituut Nederland 18 augustus 2014.

${ }^{29} 8 \mathrm{e}$ en 9e monitor Regeling financiering zorg onverzekerbare vreemdelingen, Zorginstituut Nederland 18 augustus 2014 resp. 8 oktober 2015.

${ }^{30}$ Nationale ombudsman 2013.

${ }^{31}$ Reactie van staatssecretaris Teeven op het rapport over medische zorg voor vreemdelingen, 28 november 2013, kenmerk 453589. Volgens de Staatssecretaris brengt het leven in illegaliteit risico's met zich mee, waaronder gezondheidsrisico's.
} 
Aanhoudende signalen dat ongedocumenteerden problemen ervaren in de toegang tot de zorg leidden twee jaar later tot gezamenlijke aanbevelingen van de Nationale ombudsman, de ACVZ en het College voor de Rechten van de Mens aan de overheid. De aanbevelingen zagen vooral op het actief uitdragen van het recht op medische zorg van ongedocumenteerden, het bijscholen van zorgverleners en poortwachters in de zorg over de rechten van ongedocumenteerden en het verstrekken van informatie. Herhaald werd de eerdere aanbeveling van de Nationale ombudsman om een centraal meldpunt in te richten waarin patiënten en zorgverleners de daadwerkelijke belemmeringen in de toegang tot zorg van onverzekerde vreemdelingen monitoren. $^{32}$

\subsubsection{Factoren aan de kant van zorgverleners}

Niet alle zorgverleners zijn op de hoogte van de definitie van medisch noodzakelijke zorg en de toepassing ervan in de praktijk. In de praktijk worden definities van te leveren zorg gebruikt die enger zijn omschreven zoals acute zorg, zorg in geval van levensbedreiging of hoogst noodzakelijke zorg. Dit kan leiden tot een beperktere toegang van ongedocumenteerden tot zorg. ${ }^{33}$ Deze bevinding is niet geheel in lijn met de conclusie van Dokters van de Wereld, waarin staat dat het begrip 'medisch noodzakelijke zorg' door Nederlandse artsen ruim wordt geïnterpreteerd. ${ }^{34}$

Onbekendheid met de bijdrageregeling bij zorgverleners is een ander veelgenoemd knelpunt. De overheid heeft tot taak zowel zorgverlener als de vreemdeling te informeren over de bijdrageregeling. Van belang is om zowel kennis en vaardigheden van ongedocumenteerden te versterken als om betere en gerichtere informatievoorziening aan zorgverleners te verstrekken. ${ }^{35}$ Onderzoek laat echter zien dat het onderwerp 'zorg aan ongedocumenteerden' zelden is opgenomen in het opleidingscurriculum van huisartsen. ${ }^{36}$ De KNMG behandelt het onderwerp op de website en artsen wijzen elkaar regelmatig in publicaties erop dat mensen zonder papieren recht hebben op medische zorg. ${ }^{37}$ Deze verantwoordelijkheid van de overheid lijkt dus door zelfregulering te worden ingevuld. Of dat voldoende is, is niet bekend.

\subsubsection{Belang van monitoring}

Er bestaat in Nederland geen structureel monitoringssysteem van de toegankelijkheid van zorg voor ongedocumenteerden. Gebrek aan data zorgt enerzijds wellicht voor onderschatting van de problemen die ongedocumenteerde migranten ondervinden en anderzijds voor het gebrek aan publiek bewustzijn van dit onderwerp. ${ }^{38}$

Weigeringen en belemmeringen bij de toegang tot zorg zijn lastig te meten en worden

\footnotetext{
${ }^{32}$ Verslag van de bijeenkomst 'Zorgeloos op straat', Brief van Adviescommissie voor Vreemdelingenzaken, de Nationale ombudsman en het College voor de Rechten van de Mens aan de Minister van VWS, U 2015/0479, Den Haag: 16 december 2015.

${ }^{33}$ Pharos 2019, p. 9.

${ }^{34}$ Dokters van de Wereld 2016, p. 49.

${ }^{35}$ Kennisplatform Integratie \& Samenleving 2018, p. 7. Pharos benoemt een aantal werkzame elementen die een positieve invloed kunnen hebben op het vergroten van de toegankelijkheid en kwaliteit van zorg, Pharos 2019.

${ }^{36}$ Dibbets 2017. De Johannes Wierstichting heeft een e-learning gezondheidszorg voor ongedocumenteerden ontwikkeld, johannes-wier.nl.

${ }^{37}$ Bijvoorbeeld Toonders e.a., MC 2020/10, p. 24-28.

${ }^{38}$ De Vito et al, 2015, p. 16
} 
niet geregistreerd. ${ }^{39}$ Denk aan het gebrek aan registratie door abortusklinieken van het aantal vrouwen dat uiteindelijk geen abortus ondergaat omdat zij dat niet kunnen betalen. ${ }^{40} \mathrm{De}$ overheid vond de hierboven vermelde aanbeveling van de Nationale ombudsman om een centraal meldpunt in te richten niet nodig, omdat meldingen bij het $\mathrm{ZiNL}$ (thans het CAK) kunnen worden gedaan. ${ }^{41}$ Inmiddels heeft het CESCR in de eerder vermelde verklaring (paragraaf 6.2.8) bij staten die partij zijn erop aangedrongen om gegevens te verzamelen over de mate waarin (onder meer) migranten zonder papieren de rechten van het convenant genieten. Het verzamelen van dergelijke gegevens kan een belangrijke bijdrage leveren aan de vaststelling en uitvoering van beleid dat gericht is op verbetering, voor de toegang tot gezondheidszorg voor migranten. ${ }^{42}$

De overheid zou eerdere toezeggingen om onderzoek naar het functioneren van de toegang tot medisch noodzakelijke zorg te bevorderen, gestand moeten doen. ${ }^{43}$ Proactief dient onderzoek te worden gedaan naar de gezondheid van onrechtmatig verblijvende vreemdelingen. Knelpunten in het weigeren van zorg dienen te worden gemonitord teneinde een beter beeld te krijgen van de specifieke problematiek van onrechtmatig verblijvende vreemdelingen. Een goede suggestie is om ook oplossingen voor de knelpunten te monitoren om zodoende bij te dragen aan structurele oplossingen. ${ }^{44}$ Het monitoren is een taak van de overheid aangezien gezondheid van migranten een zaak van publieke gezondheid is. Tevens noopt de oproep van het CESCR daartoe. Monitoren is nodig om de toegang tot zorg van ongedocumenteerden te verbeteren. ${ }^{45}$

\subsection{Tussenconclusie}

Geconcludeerd kan worden dat de bijdrageregeling ex artikel 122a Zvw tot een verbetering in de toegankelijkheid van zorg voor de onverzekerbare vreemdeling heeft geleid ten opzichte van de eerdere financieringsregeling. Onderzoeken tonen echter aan dat zich ook nu nog barrières voordoen. Deze laten zich samenvatten als knelpunten aan de kant van de zorgverlener (onbekendheid met de regeling, onwelwillendheid om zorg te verlenen, concentratie van de zorgvraag), aan de kant van de overheid (onvoldoende zicht op de toegang tot zorg, onvoldoende voorlichting en informatie, het niet vergoeden van niet-medisch noodzakelijke zorg die later medisch noodzakelijk kan worden) en aan de kant van de vreemdeling (kwetsbaarheid, onbekendheid met de regeling). Deze barrières kunnen de feitelijke toegankelijkheid van zorg in de weg staan. In mijn ogen blijft het belang van (de interpretatie van) het begrip 'medisch noodzakelijke zorg' in deze onderzoeken onderbelicht. Een te nauwe uitleg van dit begrip leidt immers tot beperktere toegang van de zorg. Hieronder wordt daarom - aanvullend op hoofdstuk vijf - ingezoomd op dit criterium uit de bijdrageregeling.

\footnotetext{
${ }^{39}$ Dokters van de Wereld 2016, p. 53.

${ }^{40}$ Zie par. 9.8.1.

${ }^{41}$ Brief van de Minister van VWS, kenmerk 905972-146287-Z, Den Haag: 8 maart 2016.

${ }^{42}$ Committee on Economic, Social and Cultural Rights, 13 maart 2017, Duties of States towards refugees and migrants under the International Covenant on Economic, Social and Cultural Rights, par. 17.

${ }^{43}$ Onder meer Kamerstukken II 2003/04, 19 637, nr. 806, p. 12.

${ }^{44}$ Kennisplatform Integratie \& Samenleving 2018, p. 7.

${ }^{45}$ V.L. Derckx, GHLG Blog 2017.
} 


\subsection{Medisch noodzakelijke zorg}

9.6.1 Automatische koppeling met basispakket Zvw

Zoals al meermaals vermeld, maakt artikel 122a lid 2 Zvw een automatische koppeling tussen medisch noodzakelijke zorg en het basispakket van de zorgverzekering. In paragraaf 5.7 is al vastgesteld dat niet alle medisch noodzakelijke zorg onder het basispakket valt. Denk hierbij aan mondzorg voor volwassenen, anticonceptie, abortus provocatus, palliatieve zorg, bepaalde medicatie en fysiotherapie. Daarnaast is alle zorg uit het basispakket medisch noodzakelijk. De criteria, die dienen als uitgangspunten voor het bepalen of een zorgvorm in het basispakket valt zijn, noodzakelijkheid, effectiviteit, kosteneffectiviteit en uitvoerbaarheid. Bij de toepassing van deze criteria spelen maatschappelijke opvattingen een rol. Deze criteria staan dus niet gelijk aan 'medisch noodzakelijke zorg'. Of een bepaalde zorgvorm onder het basispakket valt, is uiteindelijk een politieke keuze. Gelet op de specifieke gezondheidsproblemen en -behoeften van de irreguliere migrant is het loskoppelen van het basispakket van de Zvw gerechtvaardigd door het samenstellen van een passend pakket voor deze groep. Dit werd als oplossing aangedragen in het verslag van de bijeenkomst 'Zorgeloos op straat' . ${ }^{46}$ De RMA bevat een passend pakket voor asielzoekers. Vergelijkbaar hiermee kan een 'aanspraak op maat' voor ongedocumenteerden worden vastgesteld.

\subsubsection{Verwachte verblijfsduur}

De zorgaanbieder dient de verstrekking van de zorg, gezien de aard van de prestatie en de verwachte duur van het verblijf, medisch noodzakelijk te achten. Mogen onzekerheid over hoe lang iemand nog in Nederland zal zijn en de (on)mogelijkheden voor nazorg in land van herkomst een rol spelen bij te leveren zorg? Volgens de commissie Klazinga is dat alleen gerechtvaardigd als het doel van gezondheidswinst daardoor niet onevenredig wordt geschaad. Vaak is de verblijfsduur in Nederland van een (uitgeprocedeerde) vreemdeling voor een arts niet in te schatten. Dan moet het belang van continuïteit van medische zorg zwaarder wegen. Dat gebeurt in de praktijk echter niet altijd, zoals we hierna zullen zien.

\subsubsection{Uiteenlopende interpretaties}

Zoals hiervoor aangehaald, zou het criterium 'medisch noodzakelijke zorg' in de praktijk doorgaans geen problemen opleveren. Pharos komt echter situaties en voorbeelden tegen waarin 'medisch noodzakelijke zorg' wordt uitgelegd als een beperkte vorm van zorg, zoals bijvoorbeeld 'acute zorg', 'zorg in geval van levensbedreiging' of 'alleen de hoogstnoodzakelijke zorg'. ${ }^{47}$ De casus van het dove asielzoekerskind Ewa ${ }^{48}$ - die ook enige tijd onrechtmatig in Nederland verbleef - laat zien dat de Staatssecretaris het begrip niet conform de uitleg in de parlementaire geschiedenis interpreteert.

Aangezien deze casus ook van belang is voor het recht op gezondheid van het kind (par.

\footnotetext{
${ }^{46}$ Verslag van de bijeenkomst 'Zorgeloos op straat', Brief van Adviescommissie voor Vreemdelingenzaken, de Nationale ombudsman en het College voor de Rechten van de Mens aan de Minister van VWS, U 2015/0479, Den Haag: 16 december 2015.

${ }^{47}$ Pharos 2019, p. 9.

${ }^{48}$ Ewa is een gefingeerde naam.
} 
9.8.2), volgt hierna een weergave van de feiten en juridische procedures met betrekking tot deze casus.

In 2013 kwam de toen eenjarige Ewa samen met haar gezin vanuit Afghanistan naar Nederland. Het gezin vroeg asiel aan en verbleef in een asielzoekerscentrum. Ewa bleek vanaf de geboorte doof te zijn. In 2014 is ze door het Universitair Medisch Centrum Groningen (UMCG) onderzocht, mede om te beoordelen of zij in aanmerking kon komen voor cochleaire implantaten (CI's), speciale gehoorimplantaten waarmee dove kinderen weer kunnen leren horen en spreken. Het UMCG vond haar een geschikte kandidaat, maar zij kwam als asielzoekerskind niet in aanmerking voor vergoeding van een CI. Een behandeling werd niet gestart. De RMA sluit vergoeding van cochleaire implantaten uit. Haar advocaat maakte bezwaar tegen deze afwijzing van de vergoeding van een CI, zowel bij het COA, verantwoordelijk voor de opvang van asielzoekers, als bij diens opdrachtgever, JenV. De asielaanvraag van het gezin werd ondertussen afgewezen, evenals een aanvraag voor verblijf op basis van de behandeling voor de doofheid van Ewa.

De Staatssecretaris van JenV wees het verzoek tot vergoeding van een CI af, omdat de Rza geen aanspraak hierop geeft. De ouders van het meisje maakten hiertegen namens het meisje bezwaar en verzochten, voordat de Staatssecretaris op het bezwaar zou beslissen, de voorzieningenrechter van de rechtbank een voorlopige voorziening te treffen.

In de procedure bij de voorzieningenrechter stond de vraag centraal of plaatsing van een CI voor het kind medisch noodzakelijke zorg is in de zin van artikel 10 lid 2 Vw. ${ }^{49}$ Volgens de Staatssecretaris is dat niet het geval, waarbij hij het begrip 'medisch noodzakelijke zorg' uitlegt als 'gevallen waarin die behandeling niet kan worden uitgesteld of onthouden zonder het leven of de gezondheidstoestand van de vreemdelinge dan wel de Nederlandse volksgezondheid, ernstig in gevaar te brengen'. ${ }^{50}$ Volgens de Staatssecretaris is sprake van een aangeboren afwijking en niet van een ziekte of aandoening die levensbedreigend is of waardoor de gezondheidstoestand van verzoekster ernstig in gevaar wordt gebracht. Er zou daarom geen sprake zijn van medisch noodzakelijke zorg.

De voorzieningenrechter stelde voorop dat de beoordeling of de behandeling medisch noodzakelijk is aan een arts is voorbehouden. Uit de door de ouders overgelegde verklaringen van diverse behandelaars, waarin (onder meer) werd aangegeven dat het meisje een geschikte kandidaat was voor een CI en dat een CI was geïndiceerd, bleek niet expliciet dat het plaatsen van een CI voor het meisje, gezien de aard van de prestatie en de duur van het verblijf, medisch noodzakelijk werd geacht en het daarom was aan te merken als medisch noodzakelijke zorg als bedoeld in artikel 10 lid $2 \mathrm{Vw}$, aldus de voorzieningenrechter.

De ouders gingen in beroep tegen het ongegrond verklaren van hun bezwaar tegen het besluit van de Staatssecretaris. ${ }^{51}$ In deze procedure boog de rechtbank zich onder meer over het oordeel van (de verdediging van) de ouders dat zij, zolang zij feitelijk in Nederland verblijft, recht heeft op vergoeding van medische kosten conform het basispakket van de zorgverzekering, waarin vergoeding van een CI wel is opgenomen. Volgens de rechtbank was er geen grond voor het oordeel dat medische behandelingen die onder het basispakket van de

\footnotetext{
${ }^{49}$ Rb. Den Haag (vzr.) 1 februari 2016, ECLI:NL:RBDHA:2016:860.

${ }^{50}$ Ro. 8.2.

${ }^{51}$ Rb. Den Haag 5 oktober 2016, ECLI:NL:RBDHA:2016:12328.
} 
zorgverzekering voor vergoeding in aanmerking komen, steeds medisch noodzakelijke zorg betreffen. Daarnaast oordeelt de rechtbank dat de ouders niet onderbouwd hebben gesteld dat de implantatie van een CI in haar situatie medisch noodzakelijk is. Het beroep wordt ongegrond verklaard.

In deze zaak geeft de Staatssecretaris een (te) enge uitleg van het begrip medisch noodzakelijke zorg, namelijk zoals die aanvankelijk in het wetsontwerp van de Koppelingswet is gegeven. De Staatssecretaris - en in het algemeen de overheid - zou zich dienen te houden aan de richtlijn van de commissie Klazinga, die medisch noodzakelijke zorg als verantwoorde en passende medische zorg definieert. Bovendien had het begrip uitgelegd dienen te worden in het belang van het kind.

\subsubsection{Tussenconclusie}

Medisch noodzakelijke zorg is een begrip dat uitsluitend door de artsen kan worden beoordeeld. Het dient te worden uitgelegd conform de uitleg van de commissie Klazinga als verantwoorde en passende medische zorg. Als de verblijfsduur niet is in te schatten, dient de continuïteit van zorg zwaarder te wegen. Het belang van de patiënt dient daarbij voorop te staan.

\subsection{Specifieke barrières}

\subsubsection{Mondzorg}

$\mathrm{Na}$ de invoering van de nieuwe vergoedingsregeling in 2009 bleek tandheelkunde het meest schrijnende probleemgebied. Door de koppeling van de aanspraak op vergoeding aan het basispakket Zvw, is tandheelkundige zorg uitgesloten. Dit heeft grote gevolgen gehad voor de toegang tot mondzorg van ongedocumenteerden. ${ }^{52}$

De financieringsregeling vergoedt alleen zorg die onder de basisverzekering van de Zvw valt. Geen vergoeding wordt verstrekt voor tandartsenzorg voor patiënten ouder dan 18 jaar (tot 1 januari 2011 ouder dan 21 jaar). Ook acute noodhulp valt niet onder de regeling. Voor mensen zonder rechtmatig verblijf zijn de rekeningen vaak te hoog om zelf te betalen. Daarnaast zijn er signalen dat veel tandartsen niet bereid zijn de zorg zonder betaling te verlenen. ${ }^{53}$

De verslechtering in de toegang tot tandheelkundige zorg van irreguliere migranten leidde tot de motie Slagter-Roukema c.s., waarin de toenmalige Minister van VWS werd verzocht om tandartsenzorg vanwege de te verwachten betalingsonmacht toch onder medisch noodzakelijke zorg en daarmee onder de compensatieregeling te laten vallen. Gevreesd werd dat er meer oneigenlijke verwijzingen naar de kaakchirurg zouden plaatsvinden, welke kosten wel vergoed worden (zogenoemde substitutie). Bij de afweging over een eventuele wetswijziging voor een ruimere vergoeding van tandheelkundige hulp aan onverzekerbare vreemdelingen, was een onderzoek van het College voor Zorgverzekeringen (CVZ) van belang.

\footnotetext{
52 Doeleman, Nederlands Tandartsenblad 12 februari 2010. Tandartsen kunnen op grond van de financieringsregeling alleen een bijdrage krijgen voor zorg die onder de basisverzekering van de Zvw valt: patiënten jonger dan 18 jaar, volledig uitneembare prothetische voorzieningen en bijzondere tandheelkunde.

${ }^{53}$ Het probleem in toegang tot mondzorg is overigens niet exclusief voor ongedocumenteerden. Ook volwassen Nederlanders met een laag inkomen en thuis- en daklozen hebben problemen, zie onder meer Gezondheidsraad 2012, Dokters van de Wereld 2019. De schatting is dat ruim een half miljoen mensen in Nederland om financiële redenen geen toegang hebben tot mondzorg, Dokters van de Wereld 2019, p. 5.
} 
Uit dit onderzoek bleek dat oneigenlijke verwijzingen van tandartsen naar kaakchirurgen slechts incidenteel voorkwamen. De Minister van VWS zag dan ook geen aanleiding om de aanspraak op tandheelkunde van irreguliere migranten uit te breiden, omdat de regering het onwenselijk acht dat voor mensen die niet rechtmatig in Nederland verblijven en niet bijdragen aan de solidariteit, een ruimere invulling van het begrip medisch noodzakelijke zorg zou gelden dan voor personen die wel bijdragen aan de solidariteit en wel rechtmatig verblijven.

In de loop van 2009 ontstonden lokale initiatieven om irreguliere migranten toch van tandheelkundige zorg te kunnen voorzien. Het Breed Medisch Overleg (BMO) maakte een inventarisatie van de knelpunten die er in Nederland ontstonden na de invoering van de nieuwe regeling. Het $\mathrm{BMO}$ concludeerde dat de toegang tot de tandheelkundige zorg voor ongedocumenteerde patiënten (toen nog boven 21 jaar), die over weinig of geen financiële middelen beschikken, onvoldoende was.

Uit de evaluatie van artikel 122a Zvw in $2011 \mathrm{kwam}$ naar voren dat (onder meer) het vergoeden van tandartsenzorg voor patiënten ouder dan 18 jaar van grote toegevoegde waarde zou kunnen zijn om de kwaliteit van leven te verhogen. Preventieve tandheelkundige zorg kan duurdere zorg verleend door de kaakchirurg - die wel onder de bijdrageregeling valt voorkómen. De reactie van de minister van VWS op deze conclusie was gelijkluidend aan die in 2009: de minister zag geen reden om voor de zorg aan onverzekerbare vreemdelingen een ander beleid te voeren dan voor verzekerden. Er zijn diverse initiatieven genomen om de toegang tot mondzorg voor ongedocumenteerden te verbeteren. ${ }^{54}$

Over de vraag of mondzorg tot het basispakket behoort is de discussie nog niet verstomd. Op dit moment wordt het zorgen voor een gezond gebit voor volwassenen in Nederland gezien als behorend tot de eigen verantwoordelijkheid en voor eigen rekening. De overheid zag en ziet geen aanleiding om hier voor de groep onverzekerbare vreemdelingen een uitzondering op te maken. Dit is naar mijn mening een drogreden. De reden om mondzorg voor volwassenen uit het basispakket te halen, is gelegen in de eigen verantwoordelijkheid voor de mondzorg en het zelf kunnen betalen van de nodige zorg. Een onrechtmatig verblijvende vreemdeling, die niet mag werken, kan de kosten voor de tandarts in de meeste gevallen niet zelf betalen. Bovendien kan een verzekeringsplichtige Nederlander een aanvullende verzekering afsluiten. Een ongedocumenteerde heeft deze keuze niet. De vraag is dan ook of de afweging van de regering terecht is. Op dit moment is de onverzekerde vreemdeling sterk afhankelijk van de bereidheid van de tandarts om het risico van onbetaald gebleven rekeningen te dragen.

\subsubsection{Vergoeding tolk}

De financieringsregeling biedt geen vergoeding voor het inschakelen van een tolk. Ratio hiervan is dat zorgverleners, zorginstellingen en patiënten zelf verantwoordelijk zijn voor communicatie. Het is een principiële keuze van de overheid: mensen dienen zelf de Nederlandse taal te kunnen spreken. Kunnen zij dat niet, dan zijn ze zelf verantwoordelijk voor een oplossing, bijvoorbeeld het meenemen van een mantelzorger of familielid, het gebruikmaken van alternatieven (vertaalapps, beeldmateriaal e.d.) dan wel het zelf betalen van een

\footnotetext{
${ }^{54}$ Dokters van de Wereld 2017.
} 
professionele tolk. ${ }^{55}$ Hendriks en Toebes leidden daaruit dan ook af, dat de communicatie en informed consent voor uitgeprocedeerden niet zijn gegarandeerd. ${ }^{56}$ Ook de Public International Law \& Policy Group (PILPG) concludeert dat het niet vergoeden van tolken in de gezondheidszorg strijd met het recht op gezondheid kan vormen. ${ }^{57}$ Het College voor de Rechten van de Mens acht de inzet van een tolk onontbeerlijk om het recht op gezondheid te verwezenlijken. Volgens het College is de beperking van de vergoeding in strijd met het gelijkheidsbeginsel. ${ }^{58}$ Voor kinderen dienen tolken nog een ander belang: zonder tolk kunnen kinderen voor hun ouders gaan tolken, waardoor zij informatie krijgen die niet voor hen bestemd of geschikt is. ${ }^{59}$ Als communicatie en informed consent ontbreken wegens taalbarrières, kan worden gesteld dat niet wordt voldaan aan het garanderen van de culturele aspecten van de toegankelijkheid van zorg. De norm van kwalitatief goede zorg (ex artikel 2 Wkkgz) en de norm van het goed hulpverlenerschap (ex 7:453 Wgbo) stellen eisen aan de communicatie tussen zorgverlener en patiënt. Ook de tuchtrechter verlangt dat de zorgverlener bij het informeren van patiënten die onvoldoende Nederlands spreken of verstaan de hulp inroept van iemand die de taal van de patiënt machtig is, desgewenst een professionele tolk. ${ }^{60}$

\subsection{Specifieke (kwetsbare) groepen}

\subsubsection{Vrouwen}

Zoals we al zagen in paragraaf 2.5.2, is bij vrouwen zonder rechtmatig verblijf de seksuele en reproductieve gezondheid in het geding.

Artikel 12 van het VN-Vrouwenverdrag verplicht de overheid tot het treffen van extra maatregelen om de gezondheidssituatie van vrouwen uit kwetsbare groepen, zoals vrouwen zonder rechtmatig verblijf, te bevorderen. Deze inspanningsverplichting geldt ook met betrekking tot de reproductieve gezondheid van vrouwen. ${ }^{61}$

PICUM constateerde dat er in Europese landen sprake is van een kloof tussen het recht op seksuele en reproductieve gezondheid en de praktijk. ${ }^{62}$ Het onderwerp heeft de aandacht van het Europees Parlement, dat lidstaten oproept om ongedocumenteerde vrouwen op hun rechten te wijzen. ${ }^{63}$ Ondanks het feit dat het Comité inzake de Uitbanning van Alle Vormen van Discriminatie van Vrouwen (CEDAW) Nederland aanspoorde om ongedocumenteerde vrouwen van informatie te voorzien over hoe zij toegang tot zorg kunnen krijgen, hult Nederland zich met betrekking tot dit onderwerp in stilzwijgen. ${ }^{64}$ De vraag rijst dan ook of

\footnotetext{
${ }^{55}$ Een uitzondering is gemaakt voor asielzoekers in asielzoekerscentra, cliënten van de vrouwenopvang en slachtoffers van mensenhandel.

${ }^{56}$ Hendriks \& Toebes, NJB 2016/19, p. 1347-1352.

${ }^{57}$ Het PILPG heeft een analyse gemaakt van het internationaal en nationaal kader dat van toepassing is op de beslissing van de Nederlandse overheid om tolken in de gezondheidszorg niet meer te vergoeden, pilpnjcm.nl.

${ }^{58}$ Goudsmit en Dute, MC 16 mei 2017.

${ }^{59}$ De Kinderombudsman, Kinderrechtenmonitor 2016, par. 6.7.

${ }^{60}$ CTG, 19 oktober 2006, 2005/222.

61 Toebes 2002.

62 PICUM 2016.

${ }^{63}$ European Parliament resolution of 4 February 2014 on undocumented women migrants in the European Union (2012/2115(IN)).

${ }^{64}$ Committee on the Elimination of Discrimination against Women, 'Concluding observations of the Committee on the Elimination of Discrimination against Women, The Netherlands', CEDAW/C/NLD/CO/5, par. 47, 5
} 
Nederland wel aan de eerder genoemde inspanningsverplichting voldoet. ${ }^{65}$ Dit klemt temeer nu Nederland een substantiële bijdrage wil leveren aan het VN-millenniumdoel 'improve maternal health'. ${ }^{66}$ Hieronder valt het doel dat alle vrouwen toegang hebben tot reproductieve gezondheidszorg. Meer recent zag minister De Jonge van VWS (naar aanleiding van Kamervragen over onvoldoende toegang tot seksuele en reproductieve gezondheidszorg van ongedocumenteerde vrouwen) geen aanleiding om aanvullende maatregelen te treffen. Doordat abortusklinieken meer verantwoordelijkheid hebben gekregen voor hun financiën, kunnen zij een lager tarief toepassen voor vrouwen die de behandeling niet kunnen betalen of deze volledig bekostigen. ${ }^{67}$ De financiële toegankelijkheid is daarmee volgens hem dan ook gewaarborgd. Dit toont te meer de afhankelijkheid van de onrechtmatig verblijvende vreemdeling van de bereidwilligheid van de zorgverlener tot wie hij of zij zich wendt. Door het gebrek aan financiële toegankelijkheid (niet-medisch noodzakelijke abortus wordt niet vergoed) wordt de feitelijke toegang afhankelijk van de coulancebereidheid van de zorgverlener. Dat is ongewenst en in strijd met het gelijkheidsbeginsel.

\subsubsection{Kinderen}

\subsubsection{Toegang tot zorg voor ongedocumenteerde kinderen in Nederland}

Ongedocumenteerde kinderen zijn drievoudig kwetsbaar: als migrant, als ongedocumenteerde en als kind. ${ }^{68}$ Een kind met een handicap is extra kwetsbaarheid. Kinderen verkeren in een andere situatie dan volwassenen. $\mathrm{Zij}$ hebben er niet voor gekozen om te migreren en zijn niet verantwoordelijk voor hun niet-legale status.

De toegang tot zorg van ongedocumenteerde kinderen staat onder druk. Veel ouders van kinderen zonder rechtmatig verblijf weten niet dat hun kind recht heeft op medische zorg, waardoor ze een bezoek aan bijvoorbeeld de huisarts zo lang mogelijk uitstellen. Ook bij zorgverleners bestaat onbekendheid met de wettelijke regeling, waardoor in de praktijk zorg wordt geweigerd. ${ }^{69}$ Minderjarigen zijn voor de toegang tot medische zorg extra afhankelijk. Zoals al vermeld in paragraaf 6.4.1.2, sprak het VN-Kinderrechtencomité haar zorgen uit over de beperkte toegang tot zorg van ongedocumenteerde kinderen. Het beval Nederland aan om kinderen toegang tot informatie over hun rechten, inclusief het recht op toegang tot zorg, te garanderen. ${ }^{70}$ De reactie van de regering op deze aanbeveling refereert in eerste instantie aan de vertrekplicht van iedere vreemdeling die geen recht op verblijf (meer) heeft. Zoals eerder

February 2010; 'Sixth Periodic Report of the Kingdom of the Netherlands concerning the implementation of the International Convention on the Elimination of all forms of Discrimination against Women (2008-2013)', september 2014. Er bestaat individueel klachtrecht bij vermeende schendingen van dit verdrag.

65 'List of issues and questions in relation to the sixth periodic report of the Netherlands, Addendum, Replies of the Netherlands', CEDAW/C/NLD/Q/6/Add. 1, 5 juli 2016.

${ }^{66}$ Onder meer brief van de Staatssecretaris van Buitenlandse Zaken aan de Voorzitter van de Tweede Kamer d.d. 7 mei 2012, DSO/GA-83/12.

${ }^{67}$ Brief van de Minister aan de Voorzitter van de Tweede Kamer d.d. 10 april 2019, 1498112-188198-PG, p. 3.

${ }^{68}$ Zie Council of Europe Parliamentary Assembly Recommendation on Undocumented migrant children in a irregular situation, Recommendation 1985 (2011), art. 2.

${ }^{69}$ Pharos 2010, p. 20.

${ }^{70}$ Committee on the Rights of the Child, Concluding observations on the fourth periodic report of the Netherlands, 8 June 2015, CRC/C/NLD/CO/4, par. 42 en 43. Het Comité geeft overigens niet aan hoe Nederland dit zou moeten of kunnen doen. 
gezegd, kan de vertrekplicht op grond van artikel 4 IVESCR geen reden zijn om het recht op gezondheid in te perken. Daarnaast wijst de regering erop dat de Nederlandse overheid zorgt voor opvang en onderdak van minderjarigen en indien van toepassing hun gezin en dat daarbij wordt voorzien in medische zorg. ${ }^{71}$ Aan de toegang tot informatie wordt mijns inziens ten onrechte voorbijgegaan.

\subsubsection{Gelijke rechten op zorg}

De bovengenoemde casus van het dove meisje Ewa kreeg een vervolg. In 2018 krijgt het gezin alsnog een verblijfsvergunning via de discretionaire bevoegdheid van de Staatssecretaris van JenV. Ewa krijgt dan een reguliere zorgverzekering en wordt geopereerd, waarbij zij één CI krijgt. Omdat zij inmiddels ouder is dan vijf jaar, is het maar de vraag hoe effectief deze CI zal zijn en of een tweede CI nog zinvol is. Ondertussen klaagde de advocaat bij de Kinderombudsman over de weigering de implantaten te plaatsen. Deze oordeelde niet mals: de kinderrechten van Ewa, voortvloeiend uit het IVRK, zijn ernstig geschonden. De aanbeveling luidde dat er een richtlijn moet worden opgesteld die uitgaat van het recht op ontwikkeling en het recht op gezondheidszorg van het kind, ongeacht verblijfsstatus.

Getoetst aan bovenstaande gedragscode en richtlijnen, alsmede het IVRK oordeelde de Kinderombudsman dat het meisje de CI's had moeten krijgen. De artsen van het UMCG hadden in 2014 afgezien van de ingreep omdat zij asielzoeker was en de zorg niet vergoed werd. Uit het onderzoek van de Kinderombudsman blijkt dat in 2016 na vragen van de advocaat van het gezin daar het argument bij kwam dat de noodzakelijke levenslange nazorg bij uitzetting niet kon worden gegarandeerd. Toen heeft het UMCG ook bij betrokken instanties en ministeries aandacht gevraagd voor de ongewenste situatie van het kind. Dat het UMCG geen reactie kreeg, is niet passend voor de overheid en de uitvoerders van wet- en regelgeving.

Het UMCG kon zich niet vinden in de conclusies van de Kinderombudsman. Bij het besluit in 2014 om niet over te gaan tot het operatief plaatsen van een CI waren volgens het UMCG niet de financiële motieven, maar uitsluitend het medisch oordeel doorslaggevend. Door de onzekere verblijfsstatus konden revalidatie en nazorg niet worden gegarandeerd. Zonder goede revalidatie en nazorg had het inbrengen van een CI zelfs tot levensbedreigende situaties voor haar kunnen leiden en was het inbrengen medisch onverantwoord. Het behandelteam van het UMCG was daarom niet tot dit behandeltraject overgegaan. Hierbij heeft het behandelteam steeds gehandeld binnen hun professionele standaard en de medische richtlijnen in acht genomen. ${ }^{72}$

Gelet op de richtlijn van de commissie Klazinga over de te verwachten verblijfsduur, had de medische zorg voor Ewa (van wie niet duidelijk was hoe lang zij nog in Nederland zou zijn) echter gelijk moeten zijn aan de zorg voor verzekerde kinderen. Uitgaande van het belang van het kind had Ewa volgens Bloemen en mij geopereerd moeten worden. ${ }^{73}$ Ook voor andere ernstige aandoeningen zoals epilepsie, HIV en hartafwijkingen geldt dat nazorg na uitzetting niet is gegarandeerd. Vervolgens kunnen de gebrekkige mogelijkheden voor nazorg in het land

\footnotetext{
${ }^{71}$ Brief van de Staatssecretaris van VWS aan de Voorzitter van de Tweede Kamer d.d. 13 november 2015, 839570144222-J.

${ }^{72}$ Reactie van het UMCG bij Derckx en Bloemen, $M C$ 2020/9, p. 18-21.

${ }^{73}$ Derckx \& Bloemen, MC 2020/9, p. 18-21.
} 
van herkomst vreemdelingrechtelijk meegewogen worden met oog voor het belang van het kind. Dan moet wel het belang van het kind centraal staan bij de beoordeling van zaken.

Het heeft er alle schijn van dat de artsen van het UMCG zich te veel hebben laten leiden door vreemdelingrechtelijke aspecten en te weinig hebben geredeneerd vanuit de hierboven besproken richtlijnen voor artsen en het belang van het kind. En de overheid heeft het vreemdelingenrecht laten prevaleren boven het IVRK, waarschijnlijk vanuit huiver voor precedentwerking en aanzuigende effecten.

De casus illustreert dat de Kinderombudsman en de Staatssecretaris van JenV uiteenlopende uitleg geven aan artikel 24 IVRK. De Kinderombudsman leidde uit de diverse General Comments en literatuur af dat ongedocumenteerde kinderen recht hebben op dezelfde gezondheidszorg als rechtmatig verblijvende kinderen (de discriminatoire mensenrechtenbenadering) ${ }^{74}$ De Staatssecretaris leidde uit het tweede lid van artikel 24 af dat er geen onbeperkt recht op medische zorg is (de fundamentele mensenrechtenbenadering). Het feit dat Nederland bepaalde zorg technisch gezien kan bieden betekent niet dat daarmee ook meteen een recht op die zorg ontstaat. ${ }^{75} \mathrm{Zij}$ verwees hierbij naar de zaak Paposhvili (zie hoofdstuk 7). In deze zaak ging het echter om de vraag wanneer uitzetting van een doodzieke vreemdeling in strijd komt met artikel 3 EVRM. Deze vraag was in deze casus niet aan de orde. Het is inderdaad juist dat vaste jurisprudentie van het Hof is dat het feit, dat het kwaliteitsniveau van de gezondheidszorg van de uitzettende staat hoger is dan dat van de ontvangende staat, niet de toets is om een uitzetting te verbieden. In deze zaak ging het echter niet om uitzetting, maar om de vraag welke zorg te bieden aan een kind met een medische zorgvraag. De gelijke toegang tot zorg voor ongedocumenteerde kinderen is in Nederland nog niet gegarandeerd. ${ }^{76}$

\subsubsection{Verbeterpunten ten aanzien van kinderen}

In de eerste plaats dringt zich de fundamentele vraag op of het koppelingsbeginsel niet zou moeten worden afgeschaft voor minderjarigen. De ACVZ deed al de aanbeveling om in de Vreemdelingenwet op te nemen dat het koppelingsbeginsel niet van toepassing is op minderjarige vreemdelingen, omdat de ACVZ van mening was dat op grond van internationale verplichtingen (artikelen 3 en 8 EVRM en het IVRK) opvang en andere voorzieningen geboden moeten worden aan kwetsbare personen. ${ }^{77}$ Ook de SER en de Kinderombudsman hebben aandacht gevraagd voor schrijnende situaties die voor kinderen kunnen ontstaan door het (door)koppelingsbeginsel. ${ }^{78}$ De regering achtte de uitzondering op het koppelingsbeginsel voor minderjarigen echter onnodig en ook onwenselijk. ${ }^{79}$ Gelet op de schrijnende situaties die kunnen ontstaan door het onverkort toepassen van het koppelingsbeginsel, lijkt dit beginsel per definitie niet in het belang van het kind te kunnen zijn. Heroverweging over afschaffing van het koppelingsbeginsel voor kinderen is naar mijn mening aangewezen.

\footnotetext{
${ }^{74}$ KOM p. 16.

${ }^{75}$ De Staatssecretaris van JenV, Reactie op het rapport "Waar geen wil is, is geen weg”, 30 januari 2020, 276945 , p. 5.

${ }_{76}$ Aldus ook Goeman \& Schultemaker, A\&MR 2019/9, p. 388-392.

${ }^{77}$ ACVZ 2012.

${ }^{78}$ SER 2017, Kinderombudsman 2017. Zie over het doorkoppelingsbeginsel par. 3.2.2 van dit proefschrift.

${ }^{79}$ Brief van de Staatssecretaris van Veiligheid en Justitie d.d. 21 maart 2013, Kamerstukken II 2012/13, 19637, 1630.
} 
Blijft het koppelingsbeginsel gehandhaafd, dat dient in elk geval een op minderjarigen toegespitste uitzondering voor het koppelingsbeginsel te worden geformuleerd. De term 'medisch noodzakelijke zorg' omvat niet het belang van het kind. Dit begrip zou volgens de Kinderombudsman voor kinderen als volgt moeten zijn: dat wat medisch noodzakelijk is voor een optimale ontwikkeling van het kind, nu en in de toekomst en zonder onderscheid tussen acute of electieve zorg.

Daarnaast dient het buitenwettelijk begunstigend beleid, op grond waarvan kinderen sinds de opvang in gezinslocaties onder de RMA vallen, te worden herzien. Het RMA bevat immers een aantal uitsluitingen die de bijdrageregeling niet kent. Alhoewel kinderen nu een eigen aanspraak hebben op grond van deze regeling, zijn ze voor een aanspraak op de uitzonderingen afhankelijk van de vraag of het medisch noodzakelijke zorg is. Bovendien zijn de uitzonderingen niet gemotiveerd. Bij de rechtszaken over de (weigering van) vergoeding van de CI heeft de overheid de achtergrond van deze uitzonderingen toegelicht: het gaat om behandelingen die vanwege de verblijfsrechtelijke status van de vreemdeling naar verwachting niet in Nederland kunnen worden voltooid. Het belang van het kind dient echter boven dit vreemdelingrechtelijk argument te staan. De huidige uitsluitingen in de zorg voor asielzoekers zouden niet voor kinderen moeten gelden. ${ }^{80}$

\subsubsection{Mensen met geestelijke gezondheidsproblemen}

Tot slot wordt gewezen op problemen die er zijn met betrekking tot de toegang tot de GGZ voor irreguliere migranten. ${ }^{81}$ Zoals al vermeld in paragraaf 2.6.2.3, vinden irreguliere migranten het lastig om hulp te zoeken bij psychische klachten en ondervinden zij hier ook drempels bij. ${ }^{82}$

In Nederland werd in een peiling naar de zorgbehoefte van ongedocumenteerden de toegang tot psychische zorg het vaakst als problematisch genoemd. ${ }^{83} \mathrm{Er}$ zijn echter geen cijfers bekend over beperkte toegang tot ggz-zorg. ${ }^{84}$ Dit toont de noodzaak van monitoren aan, met name gelet op de specifieke geestelijke gezondheidsproblematiek en psychosociale behoeften van de categorie uitgeprocedeerde asielzoekers. ${ }^{85}$

De bijdrageregeling vergoedt alleen zorg die is verleend door een gecontracteerde zorginstelling. Dit kan een extra belemmering vormen aangezien de verwijzer hiervan op de hoogte dient te zijn. Het CIZ mag voor bepaalde zorgvormen die onder de Wlz vallen (zoals opname in een psychiatrisch ziekenhuis of intensieve begeleiding thuis) voor irreguliere migranten geen indicatie afgeven. De instelling kan de zorg verlenen als de arts de Wlz-zorg noodzakelijk vindt. ${ }^{86}$ Dan zal het CAK dit vergoeden. Ook hier geldt de afhankelijkheid van de ongedocumenteerde van de arts.

Daarnaast vormt het gebrek aan vergoeding van tolkkosten in de geestelijke gezond-

\footnotetext{
${ }^{80}$ Aldus ook de Kinderombudsman 2019, p. 32.

${ }^{81}$ Achtergrondinformatie Dokters van de Wereld, ter gelegenheid van de rapportage 'Access to healthcare for vulnerable groups in the Europe in times of crises and rising xenophebia, an overview of the situation of people excluded form healthcare systems', 2012, Médecins du Monde en Wereldgezondheidsdag, april 2013.

${ }^{82}$ Teunissen e.a., 2014, BMJ Open 2014;4:e005738.

${ }^{83}$ Dokters van de Wereld \& Artsen zonder Grenzen, 2014.

${ }^{84}$ Pharos 2019, p. 11.

${ }^{85}$ Lahuis e.a., European Journal of Psychotraumatology 2019, 10:1.

${ }^{86}$ Stichtinglos.nl.
} 
heidszorg een probleem. Volgens ZiNL kan een tolkvoorziening in bepaalde situaties een randvoorwaarde zijn voor het verlenen van goede zorg. ${ }^{87}$ Alhoewel verzekerden geen aanspraak kunnen maken op een tolkenvoorzieningen uit hoofde van de Zvw (het is geen verzekerde prestatie), acht het ZiNL het ten aanzien van vluchtelingen niet uitgesloten dat de tolkvoorziening in de geneeskundige geestelijke gezondheidszorg ten laste van de Zvw bekostigd kan worden. De NZa zal zich hier verder over buigen. Van belang hierbij is de conclusie van het $\mathrm{ZiNL}$ dat de verantwoordelijkheid van zorgverleners voor het verlenen van goede zorg en het zo nodig het inschakelen van een tolk geldt ongeacht de status van de patiënt. Het zou derhalve aan te bevelen zijn indien het NZa zich analoog uitspreekt over de vergoeding van tolkkosten voor onverzekerbare vreemdelingen.

\subsection{Conclusie}

Ook al is het huidige systeem juridisch gevalideerd, toch zien we dat het systeem barrières met zich brengt die de feitelijke toegang tot zorg kunnen belemmeren. Deze worden vaak op lokaal niveau of via steunorganisaties weggenomen of opgelost. Het is de verantwoordelijkheid van de overheid om deze barrières zoveel mogelijk te beperken om het recht op zorg voor de gezondheid te waarborgen. Hiertoe zijn al de nodige aanbevelingen gedaan. De overheid acht de financiële en feitelijke toegankelijkheid echter voldoende gewaarborgd. Eventuele problemen daarbij zijn voor rekening van de vreemdeling die zelf het risico heeft genomen door hier illegaal te verblijven. Dit is een vreemdelingrechtelijk argument dat geen recht doet aan het recht op gezondheidszorg van deze mensen, met name niet van die van de meest kwetsbaren onder deze groep. Door de formele benadering makt de overheid het zich te gemakkelijk en daardoor zijn instellingen vaak op het verkeerde been gezet.

Uit hoofde van het recht op zorg voor de gezondheid mag meer van de overheid worden verwacht, zoals het proactief verschaffen van informatie over de regeling, het interpreteren van medisch noodzakelijke zorg conform de richtlijn van de commissie Klazinga en het structureel monitoren van de toegang tot zorg van onrechtmatig verblijvende vreemdelingen.

Door de omvang van de te verlenen zorg aan de zorgverlener over te laten, is de ongedocumenteerde te veel afhankelijk van de bereidwilligheid van de individuele zorgverlener en/of -instelling. Er is onvoldoende zicht op de knelpunten in de toegang tot zorg.

De slechte toegang tot mondzorg en het ontbreken van vergoeding voor een tolk staan op gespannen voet met het recht op gezondheidszorg. Het recht op zorg voor de gezondheid van onrechtmatig verblijvende kinderen staat onder druk. Voor hen zou het koppelingsbeginsel idealiter ongedaan dienen te worden gemaakt. Op z'n minst dient er een op kinderen toegesneden uitzondering op het koppelingsbeginsel te worden gecreëerd.

\footnotetext{
${ }^{87}$ Zorginstituut Nederland 2020, p. 5.
} 


\title{
Hoofdstuk 10 Slotbeschouwing
}

\author{
"Heel veel dingen rond zorg aan \\ ongedocumenteerden zijn goed geregeld. In \\ principe is de zorg goed toegankelijk. Zo hadden \\ we pas op het spreekuur een meneer uit een \\ Afrikaans land, hij werd gestigmatiseerd in zijn \\ land vanwege een zichtbare afwijking aan zijn \\ ogen. Hij was in Italië medisch niet goed \\ behandeld, daar is zijn ooglens verwijderd. \\ Kortgeleden heeft hij hier in het ziekenhuis \\ behandeling gekregen en hij is heel dankbaar voor \\ het goede resultaat." (Annette, verloskundige en \\ spreekuurmedewerker Dokters van de Wereld)
}

Bron: Dokters van de Wereld 2018, p. 41.

\subsection{Inleiding}

De hoofdvraag van dit proefschrift luidt:

Op welke wijze is het recht op zorg voor de gezondheid van vreemdelingen die onrechtmatig in Nederland verblijven gewaarborgd tegen de achtergrond van de Koppelingswet en het beleid op basis van deze wet? Welke verbeterpunten kunnen ten aanzien van deze waarborging worden geïdentificeerd?

In essentie kan het eerste deel van de hoofdvraag als volgt worden beantwoord. Onrechtmatig verblijvende vreemdelingen in Nederland staat het vrij om medische zorg in te roepen. Zij dienen de kosten hiervan in beginsel zelf te betalen aangezien zij als gevolg van de Koppelingswet uitgesloten zijn van de zorgverzekeringswetten. De zorgverlener kan onder bepaalde voorwaarden vergoeding ontvangen uit hoofde van de bijdrageregeling ex artikel 122a Zvw. Cruciaal is de voorwaarde dat de zorgverlener de zorg medisch noodzakelijk acht. De waarborg voor de feitelijke toegang tot de gezondheid is daardoor gelegen bij de hulpverlener/instelling.

Is de formele toegang tot medische zorg in theorie onbelemmerd, door feitelijke belemmeringen is een discrepantie gesignaleerd tussen de Nederlandse praktijk en het geanalyseerde internationale kader. Uit de beantwoording van de deelvragen blijkt dat het systeem in het licht van internationale afspraken een aantal hiaten en tekortkomingen kent. Deze kunnen worden verbeterd. Daarmee is niet gezegd dat het systeem in zijn totaliteit niet functioneert, maar dat is een andere vraag.

Hieronder (paragrafen 10.2-10.5) vat ik de bevindingen over de deelvragen samen en geef ik een nadere beschouwing over deze bevindingen in onderlinge samenhang (paragraaf 10.6). Daarna wordt het tweede deel van de hoofdvraag beantwoord (paragraaf 10.7). Tot slot 
plaats ik kanttekeningen bij het doel van de uitsluiting van zorgverzekeringswetten van onrechtmatig verblijvende vreemdelingen (paragraaf 10.8).

\subsection{Minimumaanspraken}

Deelvraag 1: Welke aanspraken op gezondheidszorg hebben onrechtmatig verblijvende vreemdelingen in Nederland ten principale?

De WHO heeft de hoogst mogelijke standaard van fysieke en mentale gezondheid, gelijkheid, non-discriminatie en gelijke toegang tot gezondheidszorg van onrechtmatig verblijvende vreemdelingen als uitgangspunt. Lidstaten dienen een migratiesensitief beleid te voeren.

Is de universele werking van het recht op gezondheidszorg uit hoofde van de VNinstrumenten controversieel geweest, buiten kijf staat dat internationaal is aanvaard dat irreguliere migranten - ondanks hun onrechtmatig verblijf - drager zijn van dit recht. Dit recht bevat een minimum-kerninhoud waarvan niet van mag worden afgeweken. Deze kerninhoud is het recht op toegang tot adequate gezondheidsvoorzieningen, goederen en diensten zonder discriminatie, het recht op spoed en primaire medische zorg en essentiële medicijnen. De zorg dient ook voor irreguliere migranten beschikbaar, toegankelijk (inclusief informatie hierover), acceptabel en van goede kwaliteit te zijn. Kinderen hebben recht op gelijke toegang tot hoogwaardige gezondheidszorg en genieten additionele bescherming.

Voor irreguliere migranten geldt - evenals voor staatsburgers - dat het recht op gezondheidszorg geen aanspraak op vergoeding hiervan inhoudt. De minimumrechten die voortvloeien uit de $\mathrm{VN}$-verdragen garanderen geen afdwingbare individuele aanspraken omdat de internationale normen niet rechtstreeks werken. Specifiek op deze groep toegesneden aanbevelingen en niet-bindende uitspraken van toezichthoudende comités zijn echter relevant gebleken voor aanspraken van onrechtmatig verblijvende vreemdelingen in de praktijk. Daarbij geven zowel het recht op leven als het recht op non-discriminatie mede vorm aan het recht op gezondheidszorg.

De meeste specifieke aanbevelingen van internationale gremia zijn slechts (dringende) aanbevelingen aan de overheid en leveren geen juridisch afdwingbare aanspraken op. Zo zal in het kader van de UHC de zorg in de toekomst betaalbaar en toegankelijk dienen te zijn voor iedereen. Dit toekomstbeeld lijkt nog ver van ons af te staan.

Concluderend kan worden gesteld dat de irreguliere migrant drager is van het recht op gezondheidszorg, maar dat hij op grond van het VN-mensenrechteninstrumentarium geen subjectief recht in de zin van een eigenstandig afdwingbare aanspraak op gezondheidszorg heeft. Wel kan hij de staat direct aanspreken als de kern van dit recht in het geding is (bijvoorbeeld bij schending van het discriminatieverbod) of als de staat verdragsverplichtingen heeft geschonden. De schending van een verdragsverplichting kan onrechtmatig zijn jegens degene die bescherming zoekt.

Met het recht op gezondheidszorg correleren positieve verplichtingen van de overheid. Deze heeft de verplichting om het recht op gezondheidszorg te respecteren, te beschermen en te bevorderen. Staten zijn verplicht om irreguliere migranten het recht op preventieve, curatieve en palliatieve zorg te verzekeren. De kerninhoud van het recht overstijgt wat nodig is om te overleven: het bevat ook het voldoen aan gezondheidsbehoeften die nodig zijn om in waardigheid te leven. De overheid heeft positieve verplichtingen om gelijke toegang tot zorg te waarborgen, ongeacht verblijfsstatus. Zowel het wegnemen van wettelijke als praktische barrières valt hieronder. Verplichtingen van de overheid zijn niet op het individu gericht, maar deze kan hier wel van profiteren. 
Het progressieve karakter van het recht op gezondheid laat niet toe dat de overheid op grond van economische recessie zou overgaan tot beperkingen op het recht op gezondheid van de irreguliere migrant. Dit houdt in dat Nederland niet zonder meer mag bezuinigen op de bijdrageregeling.

Staten mogen volgens vaste jurisprudentie van het EHRM in het domein van de sociale zekerheid bij aanspraken op sociale voorzieningen onderscheid maken op grond van verblijfsstatus. Dit hangt mede samen met het feit dat irreguliere migranten niet (kunnen) bijdragen aan de financiering ervan. Beperkingen van het recht op zorg voor de gezondheid van irreguliere migranten mogen niet leiden tot aantasting van de kerninhoud van dit recht. Het onthouden van medische bijstand in nationale wetgeving of praktijk is in strijd met het ESH (herzien).

Het EVRM is in toenemende mate van invloed op de positieve verplichtingen voor verdragsstaten op het gebied van de gezondheidszorg. Irreguliere migranten kunnen de overheid dan ook aanspreken op grond van het EVRM ten aanzien van medische zaken (bijvoorbeeld bij het weigeren van medische zorg of de vergoeding ervan in levensbedreigende situaties). Bij het respecteren en beschermen van het recht op leven mag geen onderscheid worden gemaakt op grond van verblijfsstatus. Respect voor menselijke waardigheid behoort tot de kern van het EVRM.

Het is vaste jurisprudentie van het EHRM dat de (ernstig) zieke vreemdeling geen aanspraken ontleent op het kunnen blijven profiteren van medische zorg, die wordt voorzien door de uit te zetten staat. Dat kan alleen bij dwingende humanitaire gronden, waarvoor een hoge drempel geldt.

Artikel $22 \mathrm{Gw}$ verplicht de overheid tot het nemen van de nodige maatregelen en het scheppen van de nodige waarborgen op het gebied van de gezondheidszorg, maar biedt geen subjectieve rechten voor degene die medische zorg nodig heeft. Toegang tot zorg kan met een beroep op alleen dit artikel niet worden afgedwongen.

\subsection{Vormgeving aanspraken}

Deelvraag 2: Hoe zijn deze aanspraken (als die er zijn) concreet vormgegeven in het Nederlandse systeem (uitsluiten van ziektekostenverzekeringen en financiering van medisch noodzakelijke zorg), zowel tijdens het verblijf in Nederland als in de fase van uitzetting naar het land van herkomst?

De kern van het systeem is gelegen in de financiering van medisch noodzakelijke zorg. Ter beantwoording van deze deelvraag dient in het achterhoofd te worden gehouden dat de overheid het garanderen van medisch noodzakelijke zorg van de vreemdeling voldoende gewaarborgd achtte en acht door de individuele zorgplicht van de zorgverlener. Dit terwijl de overheid uit hoofde van de internationale verdragen een eigenstandige verplichting heeft om de toegang tot zorg te waarborgen.

In eerste instantie vond de overheid het instellen van een compensatieregeling voor zorgverleners en -instellingen (het Koppelingsfonds) een onverplichte geste. Als gevolg van zowel verschillende rechtszaken als de wijziging van het zorgstelsel. werd de huidige bijdrageregeling in het leven geroepen die wettelijk verankerd is (artikel 122a Zvw). Met deze wettelijke verankering is de verplichting van de overheid om te zorgen voor toegankelijkheid van zorg uit hoofde van internationale verdragen erkend. Uitgangspunt blijft wel dat de onverzekerbare vreemdeling zelf de kosten van medische zorg dient te dragen. 
De bijdrageregeling biedt geen eigenstandige aanspraak op zorg maar biedt de zorgverlener onder bepaalde voorwaarden aanspraak op een tegemoetkoming van de kosten voor zorg verleend aan onverzekerbare vreemdelingen, waaronder onrechtmatig verblijvende vreemdelingen. De bijdrageregeling kent een onderscheid in direct toegankelijke en niet-direct toegankelijke zorg. Voor beide soorten zorg geldt een verschillend vergoedingsregime.

In vergelijking met andere landen is de bijdrageregeling ruimhartig te noemen, met name het inzake vergoeden van langdurige zorg. De regeling is feitelijk geen uitzondering op het koppelingsbeginsel aangezien de vreemdeling geen eigen aanspraak op vergoeding van medische zorg heeft gekregen. Indien de zorgverlener weigert om (verdere) zorg te verlenen, dan kan de veemdeling deze zorg alleen via de rechter met een beroep op verdragsverplichtingen afdwingen. Het bepalen van de aanspraak - en daarmee de omvang - van de te verlenen zorg is aan de zorgverlener overgelaten. Ook dient de zorgverlener in te schatten wat de duur van het verblijf is, wat lastig zo niet onmogelijk is.

Ongedocumenteerde kinderen vallen niet onder de bijdrageregeling maar (vanwege buitenwettelijk begunstigend beleid) onder de RMA. Zij hebben daardoor een eigenstandige aanspraak op bepaalde zorgvormen. De RMA kent een aantal uitzonderingen die de bijdrageregeling niet kent. Een kind dat toch in aanmerking wenst te komen voor een dergelijke uitsluiting, dient zich te beroepen op het algemene begrip 'medisch noodzakelijke zorg'. Dit begrip includeert echter niet het belang van het kind, waarbij immers ook diens recht op ontwikkeling dient te worden betrokken. Het buitenwettelijk beleid is dan ook niet ten gunste van het kind gebleken. De casus van het dove meisje Ewa is daarvan een schrijnend bewijs.

Een ernstig zieke vreemdeling, die in afwachting is van een beroep op artikel 3 EVRM tegen de afwijzing van een aanvraag van uitstel van vertrek op medische gronden (artikel 64 $\mathrm{Vw}$ ), heeft op grond van de TRi en jurisprudentie van het HvJ EU recht op dringende medische zorg en essentiële behandeling van ziekte. Na een succesvol beroep op artikel 3 EVRM valt de vreemdeling onder de Rza en heeft hij eigenstandige aanspraken op grond van de RMA.

\subsection{Functioneren koppelingsbeginsel}

Deelvraag 3: Hoe functioneert het koppelingsbeginsel in de praktijk, specifiek met betrekking tot aanspraken op medische zorg?

Het in de koppelingswetgeving gemaakte onderscheid naar verblijfsstatus is volgens vaste jurisprudentie in beginsel niet in strijd met de internationale discriminatieverboden. Alleen in zeer bijzondere omstandigheden hoeft van het beginsel te worden afgeweken op grond van het discriminatieverbod. Deze vaste lijn uit de jurisprudentie is door het EHRM geaccordeerd (Yesthla/Nederland).

Wel kan de uitsluiting van zorgverzekeringswetten in individuele gevallen op gespannen voet staan met andere internationale normen zoals het recht op leven, het recht op respect voor privéleven en het recht op menselijke waardigheid.

Tot 2012 toetste de rechter of de weigering om zorg te verlenen de normale ontwikkeling van het privéleven van de vreemdeling onmogelijk maakt ('fair balance' afweging). Sinds 2012 betrekt de Centrale Raad de bijdrageregeling bij de artikel 8 EVRM toets. Volgens de Centrale Raad is met de bijdrageregeling automatisch voldaan aan internationale verdragen, aangezien de wetgever heeft beoogd medisch noodzakelijke zorg voor vreemdelingen toegankelijk te maken. Is dit uitgangspunt in de kern juist, het gaat voorbij aan de mogelijkheid dat zorg kan worden geweigerd en dat de toegang tot zorg daardoor kan worden belemmerd. Het feit dat een vreemdeling zich rechtstreeks kan wenden tot een zorgverlener is naar mijn mening 
onvoldoende om geen schending van artikel 8 EVRM aan te nemen. De feitelijke toegang tot gezondheidszorg (waarop de Centrale Raad zich beroept) is een andere dan de financiële toegang. Een beroep doen op internationale normen om het koppelingsbeginsel buiten toepassing te verklaren kent op dit moment een (te) hoge drempel. Daardoor kan een individu buiten het humanitaire vangnet vallen. Aan de ondergrens van het recht op gezondheidszorg de menselijke waardigheid - wordt niet (altijd) toegekomen.

\subsection{Knelpunten in toegang tot zorg}

Deelvraag 4: Welke knelpunten doen zich voor bij (de toegang tot) de zorgverlening aan ongedocumenteerden (formele drempels), met name kwetsbare groepen?

Het garanderen van financiële toegankelijkheid van als noodzakelijk te beschouwen zorg is een taak van de overheid. Bij financiële belemmeringen kan de vreemdeling afzien van zorg of de zorg uitstellen. Dit leidt tot gezondheidsklachten of hogere kosten. Financiële en feitelijke toegankelijkheid van zorg hangen nauw met elkaar samen. Financiële drempels kunnen leiden tot belemmeringen in de feitelijke toegankelijkheid. Het feit dat de vreemdeling in eerste instantie de rekening dient te betalen, werpt al een eerste drempel op. Daarnaast zijn zij sterk afhankelijk van de bereidheid van de zorgverlener om hen zorg te verlenen. Het begrip medisch noodzakelijke zorg blijft een bottleneck. Hierover bestaat bij sommige zorgverleners nog steeds onduidelijkheid. Bij langdurige zorg kan de te verwachten verblijfsduur de beoordeling van de noodzakelijkheid bovendien extra compliceren.

Mondzorg is een probleemgebied, evenals problemen die vrouwen ondervinden in de toegang tot seksuele en reproductieve gezondheidszorg. Mensen met geestelijke gezondheidsproblemen ervaren knelpunten in de toegang tot geestelijke gezondheidszorg. Het feit dat de bijdrageregeling geen tolkkosten vergoedt kan leiden tot problemen in de communicatie en kan het verkrijgen van het wettelijk vereiste 'informed consent' in de weg staan. Dit staat de culturele toegankelijkheid van de zorg in de weg en is een evident knelpunt waar het gaat om het recht op gezondheidszorg. Voor kinderen is gelijke toegang tot gezondheidszorg nog niet toereikend.

Bovenstaande knelpunten zijn structureel te noemen. De overheid komt niet met oplossingen voor deze knelpunten, waarschijnlijk vanwege vreemdelingrechtelijke redenen. Uit reacties van de verantwoordelijke bewindslieden op aanbevelingen van onder meer de Nationale ombudsman en diverse rechtszaken, is af te leiden dat oplossingen voor betere (toegang tot) gezondheidszorg voor de onrechtmatig verblijvende vreemdeling worden geblokkeerd door de status van rechteloosheid (het 'niet bestaan' voor de wet) en de vertrekplicht van de vreemdeling. De vertrekplicht hoeft echter niet in de weg te staan aan het optimaliseren van de toegang tot zorg. Gebleken is immers dat een goede gezondheid juist bevorderlijk is voor de bereidheid van de vreemdeling om het land uit eigen beweging te verlaten. De discussie over het recht op gezondheidszorg van de onrechtmatig verblijvende vreemdeling wordt naar mijn mening nog te veel vertroebeld door vreemdelingrechtelijke argumenten. De vervulling van het recht op gezondheidszorg kan worden beschouwd als een essentiële voorwaarde voor een leven in menselijke waardigheid.

\subsection{Toets}

Deelvraag 5: Hoe verhoudt het Nederlandse systeem zich tot de gepositiveerde grond-en mensenrechten en gezondheidsrechtelijke principes? 
Het in dit proefschrift besproken systeem kent twee van elkaar te onderscheiden componenten: A. de uitsluiting van ziektekostenverzekeringen en B. de financiering van medisch noodzakelijke zorg. In deze paragraaf wordt het antwoord op deze deelvraag besproken aan de hand van een afzonderlijke bespreking van deze componenten.

\section{Ad A: uitsluiting van ziektekostenverzekeringen (koppelingsbeginsel).}

Ten aanzien van het uitsluiten van ziektekostenverzekeringen doet het systeem naar mijn mening onvoldoende recht aan het recht op zorg voor de gezondheid van de onrechtmatig verblijvende vreemdeling. Bezien we de uitzondering op het koppelingsbeginsel zuiver, dan hadden zij überhaupt niet 'ontkoppeld' mogen worden van de zorgverzekeringswetten maar een eigenstandige aanspraak op voorzieningen dienen te behouden met op hun specifieke situatie toegespitste aanspraken. De wetgever heeft hier echter niet voor gekozen. De uitzondering op het koppelingsbeginsel heeft de jure dan ook slechts betrekking op de financiering van medisch noodzakelijke zorg, verleend aan vreemdelingen zonder rechtmatig verblijf.

Door de wijze waarop de rechter de financieringsregeling betrekt bij de artikel 8 EVRMtoets (zie paragraaf 10.4), komt de rechter ten onrechte niet meer toe aan toetsing van individuele gevallen aan mensenrechten. Het feit dat de bijdrageregeling bestaat, sluit immers niet uit dat er individuele gevallen bestaan waarbij de normale ontwikkeling van het privéleven van de vreemdeling onmogelijk wordt gemaakt of waarbij sprake is van strijd met andere fundamentele rechten of menselijke waardigheid. De toets gaat uit van een algemene waarborg in plaats van een op het individu toegesneden mensenrechtenbenadering.

De effectieve operationalisering van het recht op gezondheidszorg is onvoldoende. Van de (zieke) onrechtmatig verblijvende vreemdeling wordt verwacht dat hij zich zelf tot de zorgverlener wendt en bij weigering om zorg te verlenen een procedure bij de rechter start. Dat vraagt om een sterke zelfredzaamheid van de vreemdeling, die zich juist in een kwetsbare positie bevindt. Vanuit de gezondheidsrechtelijke rechtsbeginselen (met name het beschermingsbeginsel) acht ik een meer laagdrempelige rechtsgang aangewezen.

\section{Ad B: het financieren van medisch noodzakelijke zorg.}

De overheid achtte de toegankelijkheid van medisch noodzakelijke zorg van de onrechtmatig verblijvende vreemdeling voldoende gewaarborgd. Ongeacht het koppelingsbeginsel kunnen zij zich immers onbelemmerd tot de zorgverlener wenden. Deze is vanuit zijn beroepsethiek gehouden om dezelfde zorg te verlenen aan de vreemdeling als aan staatsburgers. Tezamen met deze zorgplicht is de staat op grond van internationale verdragen verantwoordelijk voor de toegang tot medisch noodzakelijke zorg. Deze omvat naast de feitelijke toegang ook de beginselen non-discriminatie, betaalbaarheid van zorg en de toegang tot informatie rond geboden zorg.

De overheid ging ervan uit dat bovengenoemde zorgplichten elkaar dekken, wat niet het geval is. De verplichtingen van de overheid uit hoofde van internationale verdragen en artikel $22 \mathrm{Gw}$ kunnen niet zomaar worden afgekoppeld en afgewend op de hulpverlener. De bijdrageregeling is bedoeld om de zorgverlener te compenseren, maar kan de verplichtingen van de overheid niet geheel 'afkopen'. De bijdrageregeling vergoedt immers niet alle medisch noodzakelijke zorg. De medische behoefte van de vreemdeling loopt dan ook niet altijd synchroon met de vergoedingsregeling van de bijdrageregeling. Daarnaast zijn niet alle zorgverleners op de hoogte van de regeling en kan zorg worden geweigerd. De omvang van het recht op zorg is aan de zorgverlener overgelaten. Deze bepaalt of de zorg medisch noodzakelijk 
is. Op zich is het terecht dat dit aan de meest deskundige beroepsgroep is toevertrouwd, maar daarmee bepaalt de zorgverlener feitelijk welke zorg aan de ongedocumenteerde wordt geleverd. Het ten onrechte weigeren van zorg of het verlenen van onvoldoende zorg kan in uitzonderlijke gevallen in strijd zijn met de artikelen 2 of 3 EVRM.

Kijkend naar de minimum kernverplichtingen uit hoofde van artikel 12 IVESCR, kan worden geconcludeerd dat de bijdrageregeling recht doet aan deze kernverplichtingen (toegang tot adequate gezondheidszorgvoorzieningen, goederen en diensten zonder discriminatie, het recht op spoed en primaire medische zorg en essentiële medicijnen). Zorg gerelateerd aan zwangerschap en geboorte wordt voor $100 \%$ vergoed. De automatische koppeling aan het basispakket van de Zvw doet echter geen recht aan de specifieke gezondheidsproblematiek van de irreguliere migrant. De uitsluiting van mondzorg en (medisch niet noodzakelijke) abortus is voor de ongedocumenteerde problematisch en leidt tot gezondheidsproblemen. De uitsluiting van tolkkosten staat op gespannen voet met internationaal recht (recht op informatie) en de in de Wgbo neergelegde eis van informed consent (artikel 7:448 jo $450 \mathrm{Wgbo}$ ).

Tegen het argument dat mogelijke bevoordeling van onverzekerbare vreemdelingen (bijvoorbeeld door het samenstellen van een specifiek pakket voor deze groep) ongelijke behandeling inhoudt ten opzichte van onverzekerde ingezetenen kan worden ingebracht dat de vreemdeling zich in een significant ongelijke positie bevindt en dat ongelijke behandeling dientengevolge gerechtvaardigd is. Als sociaal grondrecht is het recht op gezondheidszorg een participatierecht. Het is irreguliere migranten niet toegestaan om te participeren in de sociale verzekeringen. Hun kan dus niet worden tegengeworpen dat zij niet participeren.

De marktprikkel die beoogd is met de 80/20-regeling is onterecht. Het karakter van de bijdrageregeling als stimuleringsmaatregel is vanuit juridisch perspectief onvoldoende. De regeling is onontbeerlijk voor de financiële toegankelijkheid van zorg voor de onrechtmatig verblijvende vreemdeling. Het is niet gebleken dat zorg wordt geweigerd vanwege de onvolledige vergoeding (80\%). Mocht de regeling worden gewijzigd in een 70/30-regeling, dan wordt de kans op weigering van zorgverlening om financiële redenen groter. Het is dan ook terecht dat de minister de 80/20-regeling niet heeft gewijzigd. Een kleine financiële bijdrage van de ongedocumenteerde (de 5-euro-maatregel) blijkt de toegang tot zorg (in dit geval medicijnen) niet in de weg te staan. Dat is positief te noemen en biedt een voorbeeld voor het invoeren van andere maatregelen teneinde misbruik van de regeling tegen te gaan.

Het gecreëerde systeem veronderstelt dat de feitelijke toegang tot zorg is gegarandeerd en dat de financiële drempels deze feitelijke toegang niet in de weg staan. Onderzoek naar de vierde deelvraag laat echter zien dat de realiteit vaak anders is. Diverse barrières kunnen de feitelijke toegang tot zorg belemmeren (paragraaf 10.5). Het gecreëerde juridische bouwwerk leidt juist tot gezondheidsproblemen. Bij financiële belemmeringen kan de zorgbehoeftige afzien van zorg of het gebruik ervan uitstellen, waardoor de gezondheidsproblematiek verergert en de kosten van zorg uiteindelijk hoger worden. Goed zicht op de problematiek is er echter niet vanwege gebrek aan harde data. Er zijn geen meldingen van weigeringen van zorg bij de IGZ. Ongedocumenteerden zijn immers huiverig om overheidsinstanties te benaderen. Positief is overigens dat de hulpverlener in Nederland niet naar de verblijfsstatus van de vreemdeling mag vragen. Er zijn geen problemen bekend ten aanzien van het beroepsgeheim bij zorgverlening aan deze groep.

Uitgangspunt van het gezondheidsrecht is dat noodzakelijke zorg voor iedereen gelijkelijk beschikbaar dient te zijn op basis van medische behoefte. Door de automatische koppeling met het basispakket van de Zvw en de Wlz wordt niet alle medisch noodzakelijke zorg vergoed. Daar komt nog bij dat de medische behoefte van de irreguliere migrant vaak niet 
diens prioriteit is, terwijl wel sprake kan zijn van aan migratie en verblijfsstatus inherente specifieke gezondheidsproblematiek.

Het binnen Nederland zonder onderscheid geldende zelfbeschikkingsbeginsel veronderstelt een bepaalde mate van vrijheid om keuzes te maken. Bij een vreemdeling zonder rechtmatig verblijf is dat vaak niet het geval. Diverse barrières (financieel, sociaal, fysiek, taalkundig) kunnen de volledige uitoefening van zijn zelfbeschikkingsrecht in de weg staan. De drempels die ongedocumenteerden ervaren in de toegang tot zorg laten zien dat de medische ethiek op zichzelf onvoldoende is om de feitelijke toegang te garanderen. Behoudens acute nood mag een geneeskundige behandeling in beginsel worden geweigerd om financiële redenen. Bij het aangaan van de geneeskundige behandelingsovereenkomst dient vervolgens wel dezelfde zorg te worden verleend als aan andere patiënten.

Bij het inroepen van langdurige zorg is het gelijkheidsbeginsel in het geding. De vreemdeling kan immers alleen terecht bij instellingen die een contract hebben met het CAK. Van keuzevrijheid is dan ook niet volledig sprake.

Het recht op preventie (vaccinaties, bevolkingsonderzoek) is lastig te verwezenlijken als het woonadres van de vreemdeling onbekend is. Vanuit het perspectief van publieke gezondheid is bescherming van de gezondheid van irreguliere migranten aangewezen.

Op grond van het bovenstaande concludeer ik dat de overheid het recht op gezondheidszorg van de onrechtmatig verblijvende vreemdeling weliswaar expliciet erkent, maar dat de overheid dit recht meer concreet in lijn met (de overkoepelende) geldende mensenrechten dient te operationaliseren. Deze conclusie wordt mede gevoed door het feit dat Nederland het Biogeneeskundeverdrag niet heeft geratificeerd (onder meer) vanwege twijfels over de garantie van gelijke toegang tot gezondheidszorg van passende kwaliteit van ongedocumenteerden.

Het recht op gelijke zorg van kinderen is nog ontoereikend gewaarborgd. De Staatssecretaris van JenV gaat uit van een fundamentele mensenrechtenbenadering. De argumentatie die hieraan ten grondslag acht ik echter onjuist. Er wordt geen rekening gehouden met het belang van het kind en diens recht op een optimale ontwikkeling. De gezondheid van het kind dient holistisch benaderd te worden. De beroepsgroep gaat wel uit van een gelijk recht op gezondheidszorg van kinderen. Daar kan de overheid niet bij achterblijven. De overheid kan het uitgangspunt gelijke rechten op gezondheidszorg van ongedocumenteerde kinderen in mijn optiek slechts gestand doen door het afschaffen van het koppelingsbeginsel voor minderjarigen. Hiertoe hebben de ACVZ en de Kinderombudsman al vergeefs eerder opgeroepen. De uitzonderingen die zijn gemaakt op de RMA kunnen in strijd komen met het belang van het kind.

In medische uitzettingszaken is de menselijke waardigheid van de irreguliere migrant het meest in het geding. Het EHRM heeft de positieve verplichting van de overheid omgebogen naar een negatieve verplichting, waardoor het een 'fair balance' test in dit soort zaken mogelijk heeft gemaakt. Daardoor spelen budgettaire overwegingen een rol bij de medische uitzettingszaken, terwijl dit in andere artikel 3 EVRM-zaken geen rol speelt. De drempel voor vaststelling van een inbreuk op artikel 3 EVRM in verband met de medische toestand van de vreemdeling is bijzonder hoog. Door het arrest Paposhvili is de drempel weliswaar enigszins verlaagd (de vreemdeling hoeft niet bijna dood te zijn, maar kan ook bij ernstig lijden een beroep doen op artikel 3 EVRM), maar dit is in het BMA-Protocol beperkt tot twee gevallen (volledig verlies van ADL-zelfstandigheid of gedwongen opname in een psychiatrisch ziekenhuis). Deze interpretatie doet onvoldoende recht aan de EHRM-jurisprudentie. Bovendien is de bewijslast, inhoudende dat de zorg niet beschikbaar is in het land van herkomst, 
bijzonder zwaar. Na een succesvol beroep op artikel $64 \mathrm{Vw}$ valt de vreemdeling onder de RMA en kan hij aanspraken maken op medische zorg.

\subsection{Verbeterpunten}

Deelvraag 6: Welke verbeterpunten zijn er aan te wijzen als het gaat om het in Nederland gevoerde beleid in het licht van de Koppelingswet en het recht op gezondheidszorg van de onrechtmatig verblijvende vreemdeling?

Het creëren van een eigen verzekering voor de onrechtmatig verblijvende vreemdeling, die rekening houdt met diens bijzondere (verblijfs)positie en kwetsbaarheid, doet het meeste recht aan diens recht op gezondheidszorg. Het alsnog creëren van een eigen aanspraak vraagt om doorbreking van het huidige systeem, dat inmiddels is aanvaard door de rechter. Een eigen verzekeringsaanspraak van de vreemdeling zal controversieel zijn en lijkt in het huidige politieke en maatschappelijke klimaat niet reëel. Eerdere aanbevelingen hierover zijn niet opgevolgd. Sinds 2010 is er immers veel veranderd op het gebied van migratie, zowel qua aantallen als qua maatschappelijke tolerantie. De huidige bijdrageregeling is inmiddels ingebed in het Nederlandse zorgsysteem. Het lijkt dan ook reëler om de huidige situatie te optimaliseren en verbeterpunten aan te brengen in het huidige systeem. Dat kan door de knelpunten, die sinds de inwerkingtreding van de Koppelingswet min of meer dezelfde zijn gebleven, aan te pakken. Dit is nodig om de kloof tussen het recht op zorg voor de gezondheid en het vreemdelingenrecht te dichten.

\section{Adviescommissie.}

Het eerste verbeterpunt dat voortvloeit uit dit onderzoek (zie paragraaf 8.3) is het voorstel om een adviescommissie in het leven te roepen voor die gevallen waarin een niet rechtmatig verblijvende vreemdeling een beroep doet op een indicatie/vergoeding van zorg op grond van (zeer) bijzondere omstandigheden. Ik denk hierbij aan extra kwetsbare zieke vreemdelingen aan wie zorg wordt onthouden vanwege betalingsonmacht of aan het geval waarin de vreemdeling behoefte heeft aan medisch noodzakelijke zorg die niet onder het basispakket van de verzekering valt (zoals medisch niet-noodzakelijke abortus). Daarmee kan de norm op een toegankelijke manier worden ingeroepen en consistent wordt getoetst. Taak van de commissie is het oordelen over de vraag of het niet vergoeden van zorg tot schending van een mensenrecht kan leiden, in de vorm van een bindend advies aan de uitvoerende instantie. Dit scheelt de vreemdeling een lange gang naar de rechter en garandeert meer uniformiteit over de uitleg van open normen als 'ontwikkeling', 'onmenselijk' en 'strijd met menselijke waardigheid'. Bij toename van het juridische gewicht van het beginsel menselijke waardigheid, is het van belang om dit beginsel vanuit gezondheidsrechtelijk perspectief te expliciteren. Niet alleen in abstracto, maar ook in concreto.

2. Eenduidige interpretatie medisch noodzakelijke zorg.

Uit verschillende besproken adviezen, parlementaire discussies en rechtszaken blijkt dat er over de interpretatie van 'medisch noodzakelijke zorg' uiteenlopend kan worden gedacht (zie hoofdstuk 5 en paragraaf 9.6). Vanuit het gelijkheidsbeginsel bezien dient dit begrip eenduidig te worden uitgelegd en toegepast. Zowel de overheid als de zorgverlener dienen voor de interpretatie van het begrip medisch noodzakelijke zorg de richtlijn van de commissie Klazinga 
te volgen, waarin medisch noodzakelijke zorg als 'verantwoorde en passende medische zorg' wordt gedefinieerd. De inhoud van de zorg is hetzelfde als voor verzekerde patiënten. Als de verblijfsduur niet is in te schatten, dient de continuïteit van zorg zwaarder te wegen. Het belang van de patiënt dient daarbij voorop te staan.

\section{Extra eis ten aanzien van weigeren behandelingsovereenkomst.}

Sommige medisch noodzakelijke zorg valt buiten de bijdrageregeling. Dit kan voor een zorgverlener aanleiding zijn om geen behandelingsovereenkomst met een onverzekerbare vreemdeling aan te gaan of om deze niet voort te zetten, aangezien de zorgverlener niet het risico op onbetaald gebleven rekeningen wil lopen. In paragraaf 5.10 zette ik uiteen dat het nietaangaan (of niet-voortzetten) van een geneeskundige behandelingsovereenkomst met een onverzekerbare vreemdeling op grond van financiële overwegingen mijns inziens om een extra zorgvuldige afweging vraagt. De arts heeft een inspanningsverplichting om na te gaan of de te verlenen zorg onder de bijdrageregeling valt. Is dat het geval, dan vormt het feit dat een deel van de rekening (80\%) wordt vergoed naar mijn mening geen reden om de behandelingsovereenkomst niet aan te gaan. Het criterium 'acute nood', dat een uitzondering vormt op de contracteervrijheid van de arts, dient naar mijn mening in geval van een onverzekerbare vreemdeling te worden verruimd tot 'medisch noodzakelijke zorg'.

4. Bekendheid zorgverlener met de bijdrageregeling en problematiek.

Onbekendheid met de bijdrageregeling bij zorgverleners wordt veelvuldig als knelpunt genoemd (par. 9.4.2). Het is de taak van de overheid om zorgverleners informatie te verschaffen over het bestaan van de regeling en de vergoedingsmogelijkheden. De bijdrageregeling en problematiek rondom medische zorg aan ongedocumenteerden dient te worden opgenomen in de scholing van medische studenten en in medische vervolgopleidingen.

\section{Structureel monitoren.}

De overheid dient de toegang tot zorg van onrechtmatig verblijvende vreemdelingen structureel te monitoren. Deze monitoring is cruciaal voor verbetering van de toegang tot zorg van deze groep (paragraaf 9.4.3). Het CESCR dringt hier bij verdragsstaten op aan zodat kan worden beoordeeld in hoeverre de overheid aan haar verplichtingen op grond van het recht op gezondheidszorg voldoet.

\section{Passend pakket.}

De automatische koppeling van de bijdrageregeling met het basispakket van de Zvw zou kunnen worden heroverwogen. Niet alle medisch noodzakelijke zorg valt onder het basispakket en niet alle zorg uit het basispakket is medisch noodzakelijk (zie paragrafen 5.7 en 9.6.1). Een passend pakket voor de groep onverzekerbare vreemdelingen doet het meeste recht aan de gezondheidsbelangen en -behoeften van deze groep.

\section{Belang van het kind.}

Er dient meer rekening te worden gehouden met de belangen van het onrechtmatig verblijvende kind (minderjarigen). In paragraaf 9.8.2.1 zijn hiertoe verbeterpunten geformuleerd. Geconcludeerd werd dat het koppelingsbeginsel per definitie niet strookt met het belang van het kind. Voor zover dit koppelingsbeginsel voor hen gehandhaafd blijft (er zijn op dit moment geen aanwijzingen dat het koppelingsbeginsel voor kinderen wordt herzien) dient de 
uitzondering 'medisch noodzakelijke zorg' voor kinderen te worden geherformuleerd, rekening houdend met hun recht op ontwikkeling. Ik sluit me aan bij de aanbeveling van de Kinderombudsman inhoudende dat het begrip 'medisch noodzakelijke zorg' als volgt zou moeten luiden: 'dat wat medisch noodzakelijk is voor een optimale ontwikkeling, nu en in de toekomst en zonder onderscheid tussen acute of electieve zorg.' Het belang van het kind dient altijd de eerste overweging te zijn. Pas daarna dient een afweging plaats te vinden tussen het belang van het kind en overige belangen. De huidige uitsluitingen in de RMA zouden niet voor kinderen mogen gelden, aangezien deze zijn opgenomen vanuit vreemdelingrechtelijk perspectief waarbij geen rekening is gehouden met het belang van het kind.

8. Multidisciplinair advies.

Bij een kort verblijf van illegale vreemdelingen in Nederland, kunnen artsen de behandeling beperkt houden of afzien van behandeling als deze zorg kan worden uitgesteld in combinatie met de verwachting van kort verblijf in Nederland. Artsen kunnen hun verblijfsduur echter vaak niet voorspellen (zie paragrafen 5.6 en 5.8) Bij twijfel over de vraag of zorg medisch noodzakelijk is in verband met de te verwachten duur van het verblijf van de vreemdeling, is multidisciplinair advies aangewezen. ${ }^{1}$ Dit kan helpen om bij complexe casuïstiek tot een integrale beoordeling te komen, met oog voor de richtlijnen en belangen, die nu nog te vaak als tegengesteld worden gezien. Indien het kinderen betreft, dient de langdurige zorg gelijk te zijn aan die aan verzekerde Nederlandse kinderen zou worden verleend. Alleen dan kan hun recht op ontwikkeling en zorg worden gegarandeerd.

9. Naar een Paposhvili-proof beleid.

Het BMA-Protocol dient te worden heroverwogen met inachtneming van de criteria die het EHRM in het arrest Paposhvili heeft geformuleerd, te weten 'een ernstige, snelle en onomkeerbare achteruitgang van zijn gezondheidssituatie, resulterend in een intens lijden of een significante vermindering van de levensverwachting vanwege de afwezigheid van adequate medische behandeling in het herkomstland of gebrek aan toegang tot een dergelijke behandeling' (vergelijk paragraaf 7.8.3). Dit 'intens lijden' kan zich ook buiten de huidige in het Protocol genoemde situaties voordoen.

\subsection{Tot slot}

De Koppelingswet is in het leven geroepen met als doel het illegaal verblijf van vreemdelingen tegen te gaan. Het is niet te verwachten dat de wetgever in de nabije toekomst aan dit beginsel gaat tornen. Aannemelijk is dus dat onrechtmatig verblijvende vreemdelingen voorlopig uitgesloten zullen blijven van sociale voorzieningen waaronder de Zvw. Het is vooralsnog niet bewezen of en zo ja, in hoeverre het doel van de Koppelingswet (mede) is bereikt door het uitsluiten van vreemdelingen zonder rechtmatig verblijf van de Zvw en de Wlz. Er zijn mij geen studies bekend die dit effect hebben aangetoond. Het aanscherpen van het terugkeerbeleid zou volgens de evaluatie van de Koppelingswet (2001) meer effect hebben. Ook is onvoldoende aangetoond dat mensen vluchten om te profiteren van hoger niveau van gezondheidszorg of (gedeeltelijke) vergoeding van zorgkosten. De specifieke gezondheidsproblemen van de onrechtmatig verblijvende vreemdeling rechtvaardigen nader onderzoek naar de noodzakelijkheid en subsidiariteit van de Koppelingswet, toegespitst op de gezondheidszorg. Nader (empirisch)

\footnotetext{
${ }^{1}$ Al eerder voorgesteld in Derckx \& Bloemen, MC 2020/9, p. 18-21.
} 
onderzoek naar de toegankelijkheid van zorg en de rol van de bijdrageregeling is aangewezen.

De kloof tussen het recht op zorg voor de gezondheid op papier en het gebruik van de gezondheidszorg in de praktijk noopt ertoe dat de overheid de barrières zoveel mogelijk beperkt teneinde het recht op zorg voor de gezondheid te garanderen. Positieve maatregelen zijn nodig om het recht op zorg voor de gezondheid van de onrechtmatig verblijvende vreemdeling te waarborgen. 


\section{English summary}

The central theme of this dissertation is the tension between irregular migrants' right to health care within the Netherlands and their ongoing exclusion from the health insurance laws within Dutch law. Grounded in an international humanitarian perspective that espouses the universality of the right to health, I investigate the factors that inform the Dutch government's responsibility to provide medical care to irregular migrants living in the Netherlands, as well as assessing whether the current system fulfils its goal of providing 'medically necessary care' to these individuals.

In chapter one, the rationale and purpose of the research are delineated, along with the methods that were adopted to conduct the study. It is estimated that the Netherlands has tens of thousands of foreign nationals living illegally, either with or without a background in seeking asylum (undocumented or irregular migrants). Many of these people suffer from both physical and mental health problems. As a result of the Linking Act (1998), irregular migrants are currently excluded from all entitlements under both the Health Insurance Act (Zorgverzekeringswet) and the Long-Term Care Act (Wet langdurige zorg). Consequently, there are a number of barriers impacting on irregular immigrants' ability to seek out medical care. The first of these is financial in nature: given their non-legitimate status, irregular migrants are not able to insure themselves against the medical expenses they incur when seeking treatment. Therefore, in the first instance they are forced to pay the costs of medical care themselves. Moreover, generally speaking, irregular migrants simply do not dare to engage with healthcare providers for fear of being arrested. The most important barrier, of course, is the fact that medically necessary care is withheld from these foreign nationals. In social scientific literature, a distinction is drawn between informal barriers and those barriers that irregular migrants experience when seeking medical care. With respect to accessing healthcare, informal barriers pertain to, on the one hand, the language barrier between the irregular migrants and healthcare providers, and on the other hand, care providers' lack of knowledge about regulations. Formal barriers concern current health policy and the organisation of care (i.e., the system). The latter of these barriers concerns accessibility, payment, ambiguity over precisely what constitutes 'medically necessary care', as well as how duty of care is interpreted. These formal barriers are of paramount importance in this dissertation.

This dissertation is underpinned by the following research question:

In what way is the right to health care of irregular migrants residing unlawfully in the Netherlands guaranteed against the background of the Linking Act and the health care policy that is based on this Act? What specific improvements can be discerned with regard to this guarantee?

The dissertation also addresses several sub-questions, namely:

(1) What are the main entitlements of irregular migrants in the Netherlands to health care? 
(2) How are these entitlements (if indeed there are any) concretely defined in the Dutch system (exclusion from health insurance and financing of medically necessary care), both during irregular migrants' stay in the Netherlands and during the phase of deportation to their country of origin?

(3) How does the linking principle work in practice, specifically with regard to entitlements to medical care?

(4) What are the bottlenecks with regard to (accessing) healthcare for irregular migrants (formal barriers), particularly with respect to vulnerable groups?

(5) How does the Dutch system relate to fundamental and human rights and to the principles of health law?

Chapter two discusses the constitutional background of the concept of an 'irregular migrant', with particular attention being paid to their health status and right to health care. The Aliens Act 2000 (Vreemdelingenwet 2000) only pertains to when a foreign national is residing lawfully in the Netherlands. If they are not doing so, then they can be said to be residing unlawfully. Unlawful residence can occur for manifold reasons, most notably, if an asylum seeker has exhausted all legal remedies, but nevertheless opts to stay in the Netherlands. Migrants encounter various risks to their health over the course of the migration process, which is why migration can be regarded as one of the social determinants of unhealthiness. As a result of their socio-economic status (SES), irregular migrants face an accumulation of various negative health determinants, particularly with respect to social determinants. Indeed, the legal status of irregular migrants is in itself a determinant of both health and access to care. While the health status of migrants is typically better than the majority of the host country's population, this initial health benefit gradually dissipates to the national health level, or even below the level. This is referred to as the 'healthy migrant effect'. A migrant's legal status and reason for migration has also been shown to culminate in a range of specific health problems. For example, people from a migrant background are at a greater risk of oral health problems. Moreover, irregular migrant women go to the midwife later in their pregnancy than Dutch women, as well as tending to use less contraception than Dutch women as a result of financial constraints and a lack of information. They are also more likely to have abortions. Long-term insecurity, such as a lengthy asylum procedure, can also lead to developmental damage among irregular migrant children, while continually relocating is also detrimental to their health. In light of their mental and physical immaturity, children are more vulnerable to the health damage associated with the detention of irregular migrants.

The living conditions of irregular migrants combined with their history and precarious status means that irregular migrants are at a relatively high risk of psychological problems. This is particularly problematic given that they find it difficult to seek help with psychological problems, and encounter barriers when they do seek help.

There is a gap between irregular migrants' health care entitlements and their actual uptake of these entitlements. A number of factors (informal thresholds) that cause this gap are highlighted in this research, which serves to illustrate the actual problems that this group encounters. The irregular migrant is, generally speaking, not an 'ordinary' patient. These 
informal thresholds give rise to additional protection of irregular migrants, from the perspective of health law.

Chapter three focuses on the parliamentary history of the Linking Act. The purpose of the Linking Act is to both reduce unlawful residence and prevent irregular migrants from acquiring a semblance of legality. To this end, migrants residing unlawfully are excluded from social benefits, including (social) health insurance. There are four exceptions to the Linking Act, which is if the entitlement relates to 1 . education, 2 . the provision of medically necessary care, 3. the prevention of violations of public health, or 4. legal assistance to the foreign national (Article 10(2) of the Aliens Act 2000). These provisions publically funded are paid for by taxpayers, despite the fact that the persons have no residence permit.

Initially, the government did not deem it to be necessary to make an exception to the linking principle for medically necessary care. Widespread criticism of this led to the following legal exception of (initially 'acute') medically necessary care. This exception to the coupling principle has received the most attention throughout parliamentary history. Academic literature has highlighted potential conflicts between the Linking Act and international governmental obligations, the prohibition of discrimination and the right to health care (to a minimum standard). Specifically, there was a general fear within the field of health law that the Linking Act would affect irregular migrants' right to health care. The extent to which the Linking Act was in accordance with the principles of necessity and proportionality was also questioned. However, in 2020, the Linking Act remains in force.

Chapter four explains how the Dutch government has implemented and financed irregular migrants' right to medically necessary care within legislation and regulations. It recounts the history of the initial illegal aliens fund: the Linking Fund, which was managed by the Linking Foundation, before subsequently being replaced by the financing regulations of Section 122a of the Healthcare Insurance Act. This regulation stipulates that care providers who lose income as a result of providing care to uninsurable foreign nationals - including irregular migrants who are unlawfully residing in the country - may, subject to certain conditions, request a contribution from the public service provider, CAK. The basic principle here is that every uninsurable foreign national - including unlawfully residing irregular migrants - is solely responsible for the costs of the healthcare provided to them.

The scheme distinguishes between two types of medically necessary care: directly accessible and non-directly accessible care. Directly accessible care can be defined as the care that can be invoked without a prescription, referral or indication, as it is referred to in the Longterm Care Act, and that usually also must be provided directly. This includes most primary care (except for pharmaceutical care) and acute hospital care. Conversely, non-directly accessible care is that which is only accessible after a prescription, referral or indication. This concerns care provided by pharmacies, hospitals, mental healthcare institutions, nursing homes and ambulance services. A different reimbursement regime applies to both these types of care.

The irrecoverable costs of providing directly accessible care to people without a residence permit are fully reimbursed to all care providers with respect to costs related to pregnancy and childbirth, while $80 \%$ of the costs are reimbursed in all other cases, which is why it is also known as the $80 / 20$ regulation. A contract system applies to indirectly accessible 
care, in that only care providers that have been previously contracted by the CAK for this purpose are entitled to reimbursement for the costs of the care provided to irregular migrants. Other care providers and institutions are not reimbursed for providing such care. The contracts with hospitals and pharmacies take place via a tendering procedure. The CAK is responsible for the implementation of the scheme, which is paid for from the budget of the Dutch Ministry of Health. For both forms of care, a care provider will only be reimbursed if the following conditions are met:

1. there must be a (partially) unpaid account. If the costs owed can be paid by or on behalf of the patient, then a health care provider cannot use the scheme;

2. the patient is uninsured and uninsurable as a result of the Linking Act;

3. they must have provided medically necessary care, which is understood to mean care or services that are part of the basic health care package of the Health Insurance Act (with the exception of in vitro fertilisation (IVF) and gender reassignment surgery (GRS)) or the LongTerm Care Act;

4. the health care provider determines whether the care provided was medically necessary, given the nature of the medical issue and the expected duration of the stay;

5. the costs cannot be reimbursed based on any other statutory provision and must be 'reasonably appropriate' under Dutch market conditions.

Costs related to medically necessary care around pregnancy and childbirth are $100 \%$ reimbursed (Section 122a subsection 4a Health Insurance Act). In addition, irregular migrant children have access to preventive youth healthcare, as well as to the vaccination programme, which is in accordance with the national vaccination programme.

It is important to stress that the contribution scheme does not guarantee uninsurable irregular migrants an independent right to care - which has been criticised - but rather ensures that under certain conditions care providers are reimbursed for unpaid medical care bills. However, this indirect form of financing by means of the contribution scheme has now been legally enshrined. Resultantly, the Dutch government now explicitly acknowledges its obligation to ensure access to care under international treaties. It is for this precise reason that the Dutch Minister for Medical Care has not (yet) cut back on the scheme. Ultimately, whether someone has a right to care is left to the care provider, who determines whether the care is medically necessary or otherwise.

Chapter five addresses the question of precisely what constitutes medically necessary care in the context of the contribution scheme, before proceeding to consider how this concept relates to care providers' duty to provide assistance. The term 'medically necessary care' has proven to be ambiguous and thus open to heterogeneous interpretations. Over the course of the period from the introduction of the Linking Act up until the present day, it has become clear that medically necessary care encompasses more than mere care in life-threatening situations. The most controversial aspect of this debate hinges on the question of whether long-term care also comes under this definition, given the uncertain residence status of irregular migrants. At least for the time being, the final word on this issue is the guideline of the Klazinga Committee, which states unequivocally that medically necessary care is tantamount to providing responsible and appropriate medical care. Now that this advice has come to take on the status of a directive, 
it can be concluded that irregular migrants should receive appropriate and responsible care in accordance with regular care. This also applies when there are doubts about the expected duration of a person's stay. Moreover, with respect to medical ethics, there are no grounds for providing irregular migrants with different treatment than Dutch nationals. Hence, medical ethics and the standards of medical professionals themselves also serve as a guarantee that irregular migrants should have access to healthcare.

The obligation to provide assistance that is sanctioned under both criminal law and disciplinary procedures only exists in emergency situations. In this respect, the duty to provide assistance is thus narrower than the conditions for reimbursement of medical care to irregular migrants, and in and of itself does not offer sufficient guarantees for the provision of necessary medical care to irregular migrants.

Chapter six comprises an analysis of the international, regional and supranational treaties and recommendations pertaining to the right to health care. It is not evident that irregular migrants (non-citizens) are also covered by the specific scope of these various instruments. The chapter proceeds to discuss both the specific scope of each instrument and relevant rulings from international (quasi-) courts.

The right to health care is a fundamental human right that should be progressively realised, but which requires several minimum obligations on behalf of the state in order for this to occur, including ensuring people's right to access healthcare services without discrimination, especially in the case of vulnerable and marginalised groups. In recent decades, there has been an emergent interest in the question of whether the scope of the right to health care also applies to irregular migrants. The UN Migration Pact of 2018 is clear on this issue: everyone, regardless of their status, is a bearer of human rights. According to UN human rights instruments, irregular migrants' right to health care is equivalent to residents' right to health care. An integral feature of this right is the right to access adequate healthcare services, goods and services without discrimination, along with the right to receive emergency and primary medical care and essential medicines. This foundational principle of the right to health care is not subject to progressive realisation or financial constraints. Hence, restrictions on the right to health care for irregular migrants should not impact on this central tenet of the right to health care.

This right to health care is also guaranteed by the right to life, which includes the right to live a dignified life. In addition, the Sustainable Development Goals (SDGs) of universal health coverage require states to transition towards providing affordable, universally accessible and good quality healthcare. The Council of Europe's instruments are more restrictive in terms of their application than the UN human rights instruments. However, the limited personal scope of the European Social Charter (ESC) does not stand up when fundamental rights or human dignity are at stake. Women are entitled to free pre-natal and post-natal care, while children also have an equal right to health care. The European Convention on Human Rights (ECHR) plays a role, both in terms of withholding medically necessary care and deporting seriously ill irregular migrants. Finally, the Return Directive obliges EU Member States to provide urgent medical care and essential treatment for illness.

However, the minimal rights enshrined in these treaties do not yet guarantee enforceable individual entitlements to healthcare. In the absence of such concrete standards, the courts are simply not able to offer legal protection. In addition, there are both practical and financial 
barriers that impact on irregular migrants' capacity to seek healthcare. States often limit entitlements to social security benefits based on people's residence status. This distinction is, in principle, permitted. After all, in the domain of social security and the right to health care there is typically a large 'margin of appreciation'. Nevertheless, it appears from the case law of the ECHR that a distinction on the basis of residence status can constitute grounds for discrimination, depending on the individual circumstances of the case and the nature of the right in question. However, compelling reasons are necessary for this.

Chapter seven addresses the issue of the removal of seriously ill irregular migrants and the accessibility of care in their country of origin. In current case law on deportation, the European Court of Human Rights (ECtHR) has formulated basic principles for the question of whether irregular migrants with a health problem who are obliged to leave should continue to benefit from the healthcare services of the expelling state.

It is settled ECtHR case law that sick irregular migrants cannot continue to benefit from the medical care provided by the expelling state. Indeed, this is only an option in exceptional cases, where there are compelling humanitarian grounds for doing so. Nor can a right be inferred from Article 3 ECHR to receive specific treatment in the host state that is not available to the rest of the population in the country of origin.

The threshold for establishing a breach of Article 3 ECHR is (still) particularly high. It seems very unlikely that this high threshold will be lowered in the short term. The ECtHR is consistent on this point, despite extensive debates and divisions between ECtHR judges. The interpretation of "compelling humanitarian considerations" comes close to the protection of the right to life (Article $2 \mathrm{ECHR}$ ). The critical question is whether this does justice to the principle of human dignity to be protected by Article 3 ECHR. In other words, the threshold must not be set so high that human dignity is compromised as a result of other overriding interests. Inhumane treatment of ill persons, irrespective of whether they are residing legally or illegally in the EU, is contrary to human dignity and should therefore not be accepted.

The high threshold in the jurisprudence of the Court does not imply that the protection under Article 3 ECHR, as provided by the Court, is the maximum level of protection that states can provide. Rather, Member States are free to offer greater protection to foreign nationals suffering from medical problems than is mandated by case law. Indeed, the social right to health is an autonomous right, which deserves greater protection than the minimal requirements outlined in these classical rights.

It remains to be seen to what extent the shift from 'near-death' to 'serious, rapid and irreversible deterioration of his health, resulting in intense suffering or a significant reduction in life expectancy' represents a truly fundamental shift within Dutch legal practice. The high threshold does not appear (at least in the Netherlands) to have fundamentally changed in the aftermath of the Paposhvili judgement, insofar as the heavy burden of proof makes it practically impossible to comply with the standard set out in the Paposhvili judgement.

However, if an irregular migrant nevertheless successfully invokes Article 3 ECHR, then they fall under the care regulation for asylum seekers (Regeling zorg asielzoekers), and, as such, have greater entitlement to care than irregular migrants (such as reimbursement of interpreter costs (by telephone), oral care and physiotherapy) on the grounds of the Asylum 
Seeker's Medical Care Regulations (RMA, the Dutch health insurance for asylum seekers).

Chapter eight deals with jurisprudence on the legality of the linking principle. According to established case law of the highest Dutch courts, the distinction drawn in the linking principle between nationality and residence status is, in principle, not in contravention of international prohibitions against discrimination. Only in extraordinary circumstances is it necessary to deviate from the principle on the grounds of the prohibition against discrimination. The way in which the highest administrative court assesses the coupling principle in light of Articles 8 and 14 ECHR has been approved by the ECtHR (Yeshtla/Nederland). It is only in highly exceptional individual cases that the court will rule that the coupling principle should not apply.

According to established case law, the contribution scheme implements international treaties. It is on these grounds that the system of indirect exception to the coupling principle is generally accepted. However, this does not exclude the possibility that certain cases may fall outside the human rights safety net, and, in turn, leave someone receiving either insufficient care or no care whatsoever. With regard to these individual cases, an easily accessible judicial process should be created in accordance with the fundamental principles of health law, so that the standard (the right to health) can be invoked in an accessible manner.

Chapter nine examines the extent to which general shortcomings in the system can be identified, focusing on so-called formal barriers. These are barriers resulting from legislative decisions, which in the context of healthcare (exclusion of health insurance and financing of medically necessary care) can lead to insufficient guarantees over accessibility to care.

The first part of the chapter concludes that the contribution scheme pursuant to Section 122a of the Health Insurance Act has improved accessibility to healthcare services for irregular migrants in comparison to the previous financing scheme. However, studies have shown that barriers nevertheless remain. These barriers can be classified as bottlenecks on the part of the care provider (unfamiliarity with the scheme, unwillingness to provide care, concentration of the demand for care), on the part of the government (insufficient insight into access to care, insufficient information and education, non-reimbursement of non-medically necessary care that may become medically necessary) and on the part of irregular migrants themselves (vulnerability, unfamiliarity with the scheme). These barriers can all serve to impede on irregular migrants' ability to actually access healthcare, and, hence, monitoring is required to improve access to care for irregular migrants. Specific barriers are oral care (dentistry is not reimbursed by the contribution scheme) and the absence of an allowance for an interpreter.

The second part of the chapter discusses access to care for several vulnerable groups, with a particular emphasis on children. In the case of women without legal residence, sexual and reproductive health is a particularly pressing issue. For example, non-medical abortions are not reimbursed. Irregular children's right to health care in the Netherlands is elucidated through recourse to a case involving a deaf girl with no residence papers, who was not given a cochlear implant. The conclusion drawn from this case is that equal access to care for irregular children in the Netherlands is not yet guaranteed. The irregular status of irregular migrants is in itself a major obstacle to accessing mental healthcare, along with culture and language. 
In chapter ten, I provide a summary of the main findings with respect to the aforementioned sub-questions, and interpret these findings vis-à-vis each other in order to answer the main research question. With regard to the first sub-question, I conclude that although irregular migrants are fully-fledged bearers of the right to health care, they do not have a subjective right in the sense of an enforceable right to receive healthcare. Moreover, most specific recommendations by international bodies only amount to (urgent) recommendations to governments, rather than constituting legally enforceable claims. In light of the purpose of both the United Nations Convention on the Rights of the Child (UNCRC) and other international recommendations, I conclude in this chapter that irregular migrant children have an equal right to care (i.e. the discriminatory human rights approach). Seriously ill irregular migrants are not entitled to continue to benefit from medical care provided by the state that is deporting them. The only exception to this is when there are extraordinarily compelling humanitarian grounds for doing so, for which a high threshold applies.

The answer to the second sub-question is (to put it simply) that the contribution scheme does not offer an independent entitlement to care; however, under certain conditions, the care provider is entitled to reimbursement for the costs of the care provided to uninsurable foreign nationals, including irregular migrants. The contribution scheme draws a clear distinction between directly accessible and non-directly accessible care, and, indeed, there are different reimbursement regimes for each of these types of care. In comparison to other countries, the scheme in the Netherlands is relatively generous, particularly with respect to reimbursement for long-term care. However, the scheme does insufficient justice to the exception to the linking principle ('medically necessary care'), insofar as irregular migrants themselves are not entitled to any reimbursement for medical care. If the care provider refuses to grant care, then this can only be enforced through the courts by invoking treaty obligations. Determining the entitlement - and therefore the extent - of the care to be provided is ultimately the sole province of the care provider.

Irregular migrant children are also not covered by the contribution scheme, but they (due to extra-legally favourable policies) do fall under the RMA. Consequently, they have an independent entitlement to certain types of care. The RMA has several exceptions, which are not covered by the contribution scheme. For example, a child who wishes to be eligible for such an exception must invoke the general concept of 'medically necessary care'. However, this concept does not include the child's best interests, including their right to development. With regard to the third sub-question, it was concluded that there is currently a high threshold for declaring the principle of interconnection to be in non-compliance with international standards. As a result, the humanitarian safety net may fall outside the scope on an individual level.

The fourth sub-question was answered as follows. Guaranteeing the financial accessibility of healthcare that is deemed to be medically necessary is ultimately a task for the government. In the event of financial obstacles, irregular migrants typically either postpone or refrain from seeking help altogether, which, in turn, leads to increased health complaints and even higher costs. Financial accessibility and actual accessibility of care are closely related, insofar as financial barriers can create obstacles to accessing healthcare services. The fact that irregular migrants have to pay the bill in the first instance already constitutes an initial barrier. In addition, irregular migrants are also largely dependent on the willingness of care providers to 
provide them with care. The concept of what constitutes medically necessary care also remains a problem in this respect, with some care providers still being unclear on this question. In the case of long-term care, the expected length of stay can also complicate the assessment of someone's necessity to receive care.

Oral care is a particularly problematic area, as is sexual and reproductive healthcare. As well as this, people with mental health problems also continue to experience bottlenecks in accessing mental health care. The fact that the contribution scheme does not reimburse the costs associated with using an interpreter also exacerbates communication problems and potentially hinders obtaining the legally required informed consent. This stands in the way of the cultural accessibility of healthcare and is an obvious bottleneck when it comes to the right to health care. Equal access to healthcare is also not yet guaranteed for children.

The above bottlenecks are structural issues, but are not yet being tackled seriously, most likely for reasons of immigration law.

In order to answer the question of whether Dutch health law is compliant with the fundamental human right to receive care (sub question five), I considered two components of the Dutch system that can be distinguished from each other: A. the exclusion of health insurance and B. the financing of medically necessary care. Ad A: the effective operationalisation of the right to health care is currently insufficient. It can be deduced from case law that foreign nationals have to approach the care provider and, if they are refused care, initiate proceedings against this care provider themselves. This requires a strong degree of self-reliance on the behalf of the foreign national, who is in a vulnerable position. Based on the principles of health law (especially the protection principle), I consider a more accessible legal procedure to be appropriate. Ad B: Upon examining the core obligations under Article 12 of the International Covenant on Economic, Social and Cultural Rights (ICESCR), it can be concluded that the contribution scheme does do justice to these core obligations (access to adequate healthcare facilities, goods and services without discrimination, the right to emergency and primary medical care and essential medicines). However, the automatic link to the basic package of the 'Health Insurance Act ' does not do justice to the specific health problems that irregular migrants suffer from. The exclusion of oral care and (medically unnecessary) abortions is especially problematic for irregular migrants and leads to a host of other health problems. The exclusion of interpreter costs is also at odds with both international law (the right to information) and the requirement of informed consent that is outlined in the Medical Treatment Contracts Act (7:488 and 7:450 Dutch Civil Code, $\mathrm{Wg} b o$ ). Regarding children, the right to equal care remains insufficiently guaranteed. The State Secretary for the Ministry of Justice and Security espouses a fundamental human rights approach with respect to this issue. However, the underlying argument here is incorrect, insofar as the best interests of the child and their right to optimal development are not considered. To address this issue, a holistic approach should be taken with regards to the health of the child.

In medical deportation cases, the human dignity of the irregular migrant is of paramount importance. In this respect, the ECtHR has turned the government's positive obligation into a negative one, allowing for a 'fair balance' test in these cases. Consequently, budgetary considerations play a role in medical deportation cases, whereas in other Article 3 ECHR cases 
this does not play a role. The absolute lower limit of Article 3 ECHR has proved insufficient to safeguard the health and human dignity of irregular migrants. Although the Paposhvili judgment did lower the threshold (irregular migrant does not have to be near death, but can also invoke Article 3 ECHR in case of serious suffering), this is limited in the BMA Protocol to two cases (complete loss of independence or forced admission to a psychiatric hospital). This interpretation does insufficient justice to ECHR jurisprudence. Further, the burden of proof regarding care not being available in the country of origin, is particularly heavy. The answer to sub-question six suggests specific points of improvement. Firstly, allowing irregular migrants to get insurance, which would take into account their special (residence) position and vulnerability, would do the most justice to their right to health care. This would signal a clear break with the current system, which has now been accepted by the courts. Enabling irregular migrants to make their own insurance claims would undoubtedly be controversial however, and appears unrealistic in the current political and social climate. Indeed, previous recommendations to do this have not been followed. Much has changed in the area of migration since 2010, both in terms of numbers and social tolerance. The current contribution scheme is now embedded in the Dutch healthcare system. It therefore appears to be more realistic to seek to optimise the current situation by making improvements to the current system, which could be done by tackling the aforementioned bottlenecks that have remained more or less the same since the Linking Act came into force. The recommended points for improvement are as follows:

1. Advisory Committee.

I propose to set up an advisory committee for those cases in which an irregular migrant invokes an indication/reimbursement of non-reimbursed care on the grounds of extraordinary circumstances.

2. Unambiguous interpretation of medically necessary care.

Both the government and the care provider should follow the guidelines of the Klazinga Committee when interpreting the concept of medically necessary care. The content of the care should be the same as it is for insured patients. This is the only way to guarantee equal treatment.

3. Additional requirement with regards to the refusal of treatment agreement.

Failure to enter into (or to continue with) a medical treatment agreement with an uninsurable irregular migrant on the grounds of financial considerations should require additional careful consideration. Doctors have a best effort obligation to check whether the care to be provided falls under the contribution scheme.

4. Familiarity of the care provider with the contribution scheme and problems.

During their training, care providers should be informed of irregular migrants' right to health care. In addition to this, the government should also give care providers information about the existence of the scheme and the possibilities for reimbursement.

5. Monitoring.

The government should structurally monitor irregular migrants' access to healthcare. 


\section{Appropriate package.}

The automatic linking of the contribution control with the basic package of the Health Insurance Act should be reconsidered. A suitable package should be chosen for uninsurable irregular migrants. This measure would do the most justice to a migration-sensitive policy.

7. Importance of the child.

The interests of irregular migrant children should be given greater consideration. The exception 'medically necessary care' must be reformulated for them, in order to take into account their right to development. The best interests of the child should always be the primary consideration. Thereafter, the best interests of the child should be weighed against other interests. The exclusions of the RMA should not apply to children.

8. Multidisciplinary consultation.

If there is doubt over whether care is medically necessary given the expected duration of irregular migrants' stay, then multi-disciplinary consultations should be arranged. If it concerns children, then the long-term care must be equal to that which would be provided to insured Dutch children. Only then can their right to development and care be guaranteed.

9. Towards a Paposhvili-proof policy.

The BMA Protocol should be reconsidered to take into account the criteria formulated by the ECtHR in the Paposhvili judgment.

Finally.

The Linking Act was created with the express aim of combating the illegal residence of aliens. It is not to be expected that legislators will change this principle in the near future. It is therefore entirely plausible that irregular migrants will continue to be excluded from social security benefits, including the Health Insurance Act, for the foreseeable future. It has thus far not been proven whether, and, if so, to what extent, the objective of the Linking Act was (partly) achieved by excluding aliens without lawful residence from both the Health Insurance Act and the LongTerm Care Act. In fact, I am not aware of any studies that have demonstrated this effect. According to the evaluation of the Coupling Act (2001), tightening the return policy would produce a greater effect. There is also insufficient evidence that people flee their country of origin to benefit from higher levels of healthcare or (partial) reimbursement of healthcare costs. The specific health problems that irregular migrants suffer from are reason alone to justify conducting further research into the necessity and subsidiarity of the Linking Act. Further (empirical) research into the accessibility of care and the role of the contribution scheme is also recommended.

The gap between the right to health care on paper and the accessibility of healthcare in practice makes it necessary for the government to reduce as many barriers as possible, in order to guarantee irregular migrants' right to health care. In this respect, affirmative action is needed to ensure irregular migrants' right to health care. 


\section{Literatuurlijst}

\section{Literatuur}

“A Magna Carta for World Health", American Journal of Public Health 1946/9, p. 10411045.

"A Magna Carta for World Health", American Journal of Public Health 36, no. 9, p. 10411045.

Achotegui, Psychoanalytic Dialogues 2019/3, p. 252-268

J. Achotegui, 'Migrants Living in Very Hard Situations: Extreme Migratory Mourning (The Ulysses Syndrome)', Psychoanalytic Dialogues 2019, afl. 3, p. 252-268, doi: /10.1080/10481885.2019.1614826.

Addo \& Grief, European Journal of International Law 1998/9, p. 510-524

K. Addo \& N. Grief, 'Does Article 3 of The European Convention on Human Rights Enshrine Absolute Rights'? European Journal of International Law 1998, afl. 9, p. 510-524.

Baauw e.a., BMJ Paediatrics Open 2019/3

A. Baauw, e.a., 'Health needs of refugee children identified on arrival in reception countries: a systematic review and meta-analysis', BMJ Paediatrics Open 2019, afl. 3:e000516.

\section{Battjes 2019}

H. Battjes, Nr.14 Paposhvili: noot bij ECtHR 13 December 2016, No. 41738/10, in K.M. Zwaan, S.G. Kok \& E.R. Brouwer (Eds.), Rechtspraak Vreemdelingenrecht 1950-2019. Landmark Cases on Asylum and Immigration Law. Nijmegen: Ars Aequi Libri, 2019, p.173189.

Bauder, International Journal of Refugee Law 2014/3, p. 327-332

H. Bauder, 'Why We Should Use the Term 'Illegalized' Refugee or Immigrant: A Commentary', International Journal of Refugee Law 2014, afl. 3, p. 327-332, doi:10.1093/ijrl/eeu032.

\section{Beauchamp \& Childress 2012}

L. Beauchamp \& J.F. Childress, Principles of Biomedical Ethics, Oxford University Press, 7th Revised edition, 2012.

\section{Beijer, NTM/NJCM-bull. 2016/14}

M. Beijer, 'De doorwerking van positieve verplichtingen bij de bescherming van fundamentele rechten in het EU-recht: een conflict met de begrensde bevoegdheden van de EU?'NTM/NJCMbull. 2016, afl. 14.

Ten Berg \& Peeters, $A \& M R$ 2019/5, p. 223-232.

J. ten Berg \& M. Peeters, Kroniek Medisch, $A \& M R$ 2019, afl. 5, p. 223-232.

Bernini \& Engbersen, NJB 1999/2, p. 65-71.

'Koppeling en uitsluiting: over ongewenste en onbedoelde effecten van de Koppelingswet', NJB 1999, afl. 2, p. 65-71. 


\section{Bogusz e.a. 2004}

B. Bogusz e.a. (eds.), Irregular Migration and Human Rights: Theoretical, European and International Perspectives, Leiden: Martinus Nijhoff, 2004.

\section{Boukaert 2007}

S. Boukaert, Documentloze vreemdelingen. Grondrechtenbescherming doorheen de Belgische en internationale rechtspraak vanaf 1985, Antwerpen-Apeldoorn, Maklu: 2007.

\section{Brands 1997}

W.G. Brands, Behandeling na afspraak? Een onderzoek naar tuchtrechtelijke, civielrechtelijke en strafrechtelijke hulpverleningsplichten van artsen en tandartsen (diss.), Lelystad: Koninklijke Vermande, Reeks Gezondheidsrecht 6, 1997.

\section{Boeles 1997}

P. Boeles, De migratie en de jurist (oratie Leiden), Utrecht: Nederlands Centrum Buitenlanders 1997.

\section{Bogusz e.a. 2004}

B. Bogusz e.a. (eds.), Irregular Migration and Human Rights: Theoretical, European and International Perspectives, Leiden: Martinus Nijhoff 2004.

\section{Brems \& Vrielink 2010}

E. Brems \& J. Vrielink, Menselijke waardigheid in de Nederlandse Grondwet? Voorstudie ten behoeve van de Staatscommissie Grondwet (2009), Kluwer 2010.

\section{Bronsword e.a. 2014}

R. Bronsword e.a., The Cambridge Handbook of Human Dignity: Interdisciplinary Perspectives, Cambridge: Cambridge University Press 2014.

\section{Brands 2006}

W.G. Brands, 'Schept een behandelwens van de patiënt automatisch een behandelplicht voor de tandarts? Over het weigeren van een door de patiënt gewenste behandeling en het in- en uitschrijven van patiënten,' in: het Tandheelkundig Jaarboek 2006, onder redactie van C. de Baat e.a.

\section{Busser 2012}

A. Busser, Kinderen in vreemdelingenbewaring, in: G.G. Lodder en P.R. Rodrigues (red.), Het kind in het immigratierecht, Sdu uitgevers, Publicatiereeks Instituut voor Migratierecht Leiden, 2012.

Carens, Ethics \& International Affairs 2008/2, p. 163-186

J. Carens, 'The Rights of Irregular Migrants', Ethics \& International Affairs 2008, afl. 2, p. 163-186, doi:10.1111/j.1747-7093.2008.00141.x.

\section{Chauvin \& Simonnot 2012}

P. Chauvin \& N. Simonnot, Access to healthcare of excluded people in 14 cities of 7 European countries. Final report on social and medical data collected in 2012. Parijs: Medecins du Monde/Docors of the World International Network; 2013.

\section{Cholewinski 2005}


R. Cholewinski, 'Study on obstacles to effective access of irregular migrants to minimum social rights', Council of Europe, December 2005.

\section{Coomans \& Kamminga 2007}

A.P.M. Coomans \& M.T. Kamminga, 'Rechten van de Mens', in: N. Horbach, R. Lefeber \& O. Ribbelink (red.), Handboek Internationaal Recht, Den Haag: T.M.C. Asser Press, 2007.

Dalli 2018, International Journal of Minority and Group Rights 2018/ 2, p. 1-17

M. Dalli, 'Universal Health Coverage for Undocumented Migrants. The Spanish Case,' International Journal of Minority and Group Rights 2018, afl. 2, p. 1-17.

\section{Derckx, EJHL 2006/4, p. 313-319}

V.L. Derckx, 'Expulsion of Illegal Residents (Aliens) with Medical Problems and Article 3 of the European Convention on Human Rights', EJHL 2006, afl. 4, p. 313-319.

Derckx, TvGR 2017/2, p. 121-134

V.L. Derckx, 'Medische zorg aan irreguliere migranten: een status quo', TvGR 2017, afl. 2, p. 121-134.

\section{Derckx, GHLG Blog 2017}

V.L. Derckx, Monitoring needed for improving access to health care of irregular migrants.

GHLG Blog 2017, https://www.rug.nl/rechten/onderzoek/expertisecentra/ghlg/blog/monitoring-needed-forimproving-access-to-health-care-of-irregular-migrants-02-05-2017?lang=en.

\section{Derckx 2018}

V.L. Derckx, 'Tandheelkundige zorg aan irreguliere migranten: de juridische context', Dokters van de Wereld 2018, https://doktersvandewereld.org/wpcontent/uploads/2018/06/20170913_Tandheelkundige_zorg_aan_irreguliere_migranten.pdf.

\section{Derckx \& Bloemen, $M C$ 2020/9, p. 18-21}

V.L. Derckx \& E. Bloemen, 'Kind zonder verblijfsvergunning heeft ook recht op alle zorg. Belangrijke les uit een schrijnende casus van een asielzoekerskind,' $M C$ 2020, afl. 9, p. 18-21.

Desmond, Human Rights Law Review, 2016/2, p. 247-272

A. Desmond, 'The Development of a Common EU Migration Policy and the Rights of Irregular Migrants: A Progress Narrative?' Human Rights Law Review (16) 2016, afl. 2, p. 247-272, doi:10.1093/hrlr/ngw012.

\section{Dibbets 2017}

A. Dibbets, 'Zorg aan ongedocumenteerden' in de huisartsenopleiding: Een inventarisatie. Utrecht: Johannes Wier Stichting.

\section{Van Dijk e.a. 1961}

P. van Dijk e.a. (eds.), Theory and Practice of the European Convention on Human Rights, p. 11, onder verwijzing naar Yearbook IV (1961), p. 116 (138-140).

Van Dijk, NVK Magazine, februari 2020, p. 16-18

M. van Dijk, 'Gelijke rechten op goede gezondheidszorg. Richtlijn Vluchtelingenkinderen in de maak', NVK Magazine, februari 2020, p. 16-18. 


\section{Doeleman, Nederlands Tandartsenblad 12 februari 2010}

A. Doeleman, 'Door nieuwe regeling veel gebitsproblemen illegalen. Tandheelkundige hulp voor volwassen illegale patiënten niet meer vergoed', Nederlands Tandartsenblad 12 februari 2010.

\section{Drupsteen 2013}

Th. Drupsteen, 'Vreemdelingen en Nederlanders in de Nederlandse grondwetten', in: K. Groenendijk e.a., Issues that matter. Mensenrechten, minderheden en migranten, Oisterwijk: Wolf Legal Publishers, 2013, p. 315-324.

Dupper 2010, International Journal of Social Security and Workers Compensation, 2010/2, p. 61-77

O. Dupper, 'The Human Rights of (Irregular) Migrants: An International Regional and South African Perspective' (Part 1), International Journal of Social Security and Workers Compensation, 2010, afl. 2, p. 61-77.

Dupper 2011, International Journal of Social Security and Workers Compensation, 2011/1, p. 55-75

O. Dupper, 'The Human Rights of (Irregular) Migrants: An International Regional and South African Perspective' (Part 2), International Journal of Social Security and Workers Compensation, 2011, afl. 1, p. 55-75.

Dute, $T v G R$ 2015/6, p. 394-402

J.C.J. Dute, 'Buiten de (mensenrechten)orde?', TvGR 2015, afl. 6, p. 394-402.

\section{Düwell 2014}

M. Düwell, Human dignity: concepts, discussions, philosophical perspectives, in: M. Düwell e.a. (eds.), The Cambridge Handbook of Human Dignity. Interdisciplinary Perspectives, Cambridge: Cambridge University Press 2014, pp. 23-49.

\section{Engbersen \& Burgers 1999}

J. Burgers \& G. Engbersen, De ongekende stad 1: Illegale migranten in Nederland, Amsterdam: Boom 1999.

\section{Van Es e.a. 1999}

A. van Es e.a., Illegale vreemdelingen op uw spreekuur, Amersfoort: Johannes Wier Stichting 1999.

\section{Evenblij 2011}

M. Evenblij, Altijd weekend. Tien jaar gezondheidszorg aan vreemdelingen zonder geldige verblijfstitel in Nederland, Diemen: Stichting Koppeling, 2011.

\section{Evans \& Morgan 1998}

M. Evans \& R. Morgan, Preventing Torture, Clarendon Press: Oxford 1998.

Den Exter, TGE 2004, afl. 3, p. 79-82

A. den Exter, 'Medische vluchtelingen en het recht op medische zorg', TGE 2004, afl. 3, p. 7982 .

Den Exter, Diametros 2017/51, p. 1730-195 
A. den Exter, 'The Right to Healthcare Under European Law', Diametros 2017, afl. 51, p. 173195, doi:10.13153/diam.51.2017.1037.

Den Exter, EJHL 2019/2, p. 115-124

A. den Exter, 'Strasbourg Medical Expulsion Rulings: Beyond the Deathbed Requirement, EJHL 2019, afl. 2, p. 115-124.

\section{Flegar 2019}

V. Flegar, 'Vulnerability and the Right to Preventive Health Care for Asylum-Seeking and Undocumented Migrant Children', in: J.H.H.M. Dorscheidt \& J.E. Doek (eds.), Children's Rights in Health Care, Leiden: Brill / Nijhoff, p. 334-356.

Forman e.a., Health and Human Rights Journal 2014/2, p. 23-24

L. Forman e.a, 'What Do Core Obligations under the Right to Health Bring to Universal Health Coverage?', Health and Human Rights Journal (18) 2014, afl. 2, p. 23-34.

\section{De Gaay Fortmann 2016}

B. de Gaay Fortmann, Moreel erfgoed. Koers houden in een tijd van ontwrichting, Amsterdam: Prometheus 2016.

\section{Gerards 2018}

J.H. Gerards, Prohibition of Discrimination, in: P. van Dijk, F. van Hoof, A. van Rijn \& L. Zwaak (eds.), Theory and Practice of the European Convention on Human Rights, Antwerpen: Intersentia, 2018.

\section{Gerads 2011}

J.H. Gerards, EVRM - algemene beginselen, Den Haag: Sdu 2011.

Gevers, $T v G R$ 1996/3, p. 121

J.K.M. Gevers: 'Toegang tot zorg voor illegalen', TvGR 1996, afl. 3, p. 121.

Gevers, $T v G R$ 2010/5, p. 363-371

J.K.M. Gevers, 'Gezondheidsrecht: ontwikkelingen en reflecties', TvGR 2010, afl. 5, p. 363371.

\section{Grant 2011}

S. Grant, 'The recognition of migrants' rights within the UN Human right system', in: Dembour, M. (Ed.), Kelly, T. (Ed.), Are Human Rights for Migrants? London: Routlegde, 2011, p. 25-47.

Greer, Human Rights Law Review 2015/1, p. 101-137

S. Greer, 'Is the Prohibition against Torture, Cruel, Inhuman and Degrading Treatment Really 'Absolute' in Internationale Human Right Law?' Human Rights Law Review (15) 2015, afl. 1, p. 101-137.

De Groot, TvGR 1997/1, p. 2-9

G.J. de Groot, "t Is een vreemdeling zeker ...? Illegalen en het recht op zorg', TvGR 1997, afl. 1, p. 2-9. 
A.A. Gkiouleka e.a., 'Depressive symptoms among migrants and non-migrants in Europe: documenting and explaining inequalities in times of socio-economic instability', European Journal of Public Health (28), 2018, afl. 5, p. 54-60, doi:10.1093/eurpub.cky202.

\section{Goeman \& Schultemaker, $A \& M R$ 2019/9, p. 388-392}

M. Goeman \& S. Schultemaker, 'Waar geen wil is, is geen weg. Onderzoek Kinderombudsman naar weigering van gehoorimplantaten bij doof meisje', $A \& M R$ 2019, afl. 9, p. 388-392.

\section{Goudsmit en Dute, MC 16 mei 2017}

S. Goudsmit en J. Dute, 'Inzet tolk is een mensenrecht. Basisverzekering moet tolk vergoeden', MC 16 mei 2017.

\section{Harris, O'Boyle \& Warbrick 2014}

D. Harris, M. O'Boyle \& C. Warbrick: Law of the European Convention on Human Rights, Third Edition, Oxford University Press 2014.

\section{Hathaway \& Foster 2014}

J.C. Hathaway \& M. Foster, The Law of Refugee Status, $2^{\text {nd }}$ Edtion, Cambrigde University Press 2014.

\section{Den Hartogh 2014}

G.A. den Hartogh, De morele grondslagen van het gezondheidsrecht: de erfenis van Leenen, in: Vereniging voor Gezondheidsrecht, Ethiek en gezondheidsrecht, Preadvies jaarvergadering 25 april 2014, Den Haag: Sdu Uitgevers 2014.

\section{Heeren e.a., Comprehensive Psychiatry 2014/4, p. 818-825}

M. Heeren e.a., 'Psychopathology and resident status - comparing asylum seekers, refugees, illegal migrants, labor migrants and residents', Comprehensive Psychiatry, afl. 4, p. 818-825, DOI: $\underline{10.1016 / j . c o m p p s y c h .2014 .02 .003 . ~}$

\section{Van der Heijden e.a. 2015}

P.G.M. van der Heijden, 'Schattingen illegaal in Nederland verblijvende vreemdelingen 2012 - 2013', Utrecht: 2015.

\section{Hendriks, Migrantenrecht 1996/3, p. 51-56}

A.C. Hendriks, 'Kanttekeningen bij de betekenis van de Koppelingswet voor de gezondheidszorg', Migrantenrecht 1996, afl. 3, p. 51-56.

\section{Hendriks 2005}

A.C. Hendriks, In beginsel. De gezondheidsrechtelijke beginselen uitgediept (oratie Leiden), Leiden: Stichting NJCM-Boekerij 2005.

Hendriks \& Toebes, $N J B$ 2016/19, p. 1347-1352

A.C. Hendriks en B. Toebes, 'Recht op toegankelijke zorg: ook voor vreemdelingen', $N J B$ 2016/949.

\section{Hoekstra, Eindhovens Dagblad 23 november 2019}

D. Hoekstra, 'De huisarts die een patiënt weigert, dat gaan we vaker meemaken', Eindhovens Dagblad 23 november 2019. 


\section{Huber e.a. BMJ 2011}

M. Huber e.a., 'How should we define health?', BMJ 2011; 343:d4163.

\section{Huber e.a., BMJ Open 2016;5:e010091}

M. Huber e.a., 'Towards a 'patient centred' operationalisation of the new dynamic concept of health: a mixed methods study', BMJ Open 2016;5:e010091, doi:10.1136/bmjopen-2015010091.

\section{Huber e.a., $N T v G$ 2016;160:A77720}

M. Huber, M. van Vliet \& I. Boers, Heroverweeg uw opvatting van het begrip 'gezondheid', $N T v G$ 2016;160:A77720.

\section{Ingleby \& Petrova-Benedict 2016}

D. Ingleby \& R. Petrova-Benedict, 'Recommendations on access to health services for migrants in an irregular situation: an expert consensus', Brussel: International Organization for Migration (IOM) Regional Office Brussels, Migration Health Division, 2016.

Izambert, HIV AIDS Policy Law Rev. 2010/1, p. 57-58

C. Izambert, Europe: Securing legal protection against expulsion for HIV-positive migrants, HIV AIDS Policy Law Rev. 2010, afl. 1, p. 57-58.

\section{Jadad \& O'Grady, BMJ 2008; 337:a2900}

A.R. Jadad, L. O'Grady. How should health be defined? BMJ 2008;337:a2900, doi:10.1136/bmj.a2900.

De Jonge e.a., Journal of Psychosomatic Obstetrics and Gynaecology 2011/4, p. 182-188

A. de Jonge e.a., 'Limited midwifery care for undocumented women in The Netherlands', Journal of Psychosomatic Obstetrics and Gynaecology (32) 2011, afl. 4, p. 182-188.

Joseph 2019, Human Rights Law Review 2019/2, p. 347-368

S. Joseph, 'Extending the Right to Life Under the International Covenant Civil and Political Rights: General Comment 36', Human Rights Law Review (19) 2019, afl. 2, p. 347-368.

Kahn 2019, Columbia Journal of European Law 2019/2, p. 222-252

B. Kahn, 'From D. v. U.K. to Paposhvili v. Belgium: Assessing the Strasbourg Court's Legal and Institutional Approach to the Expulsion of Seriously Ill Migrants under Article 3 of the European Convention on Human Rights', Columbia Journal of European Law (25) 2019, afl. 2, p. 222-252.

Kalkman-Bogerd, in: T\&C Gezondheidsrecht, artikel 47 lid 1 sub a, Wet BIG.

L.E. Kalkman-Bogerd, commentaar op artikel 47 lid 1 sub a Wet BIG, in: T.A.M. van den Ende \& D.P. Engberts, L.E. Kalkman-Bogerd en J.J.M. Linders, T \& C Gezondheidsrecht, Handelingen op het gebied van de individuele gezondheidszorg bij: Wet op de beroepen in de individuele gezondheidszorg, Deventer: Wolters-Kluwer 2020 (boek en online).

\section{Kalverboer \& Zijlstra 2006}

M.E. Kalverboer \& A.E. Zijlstra, De schade die kinderen oplopen als zij na langdurig verblijf in Nederland gedwongen worden uitgezet. Groningen: Rijksuniversiteit Groningen, 2006.

Kirmayer e.a., Canadian Medical Association Journal, 2011/12, p. 959-967 
L.J. Kirmayer e.a., Common mental health problems in immigrants and refugees: General approach to the patient in primary care, Canadian Medical Association Journal (183) 2011, afl. 12, E959-E967; doi: 10.1503/cmaj.090292.

Kok \& Sikken 2006, $M C$ 2006/20, p. 843

M. Kok \& F. Sikken, 'Tweedeling op straat. Een toenemend aantal onverzekerde dak- en thuislozen raakt verstoken van ziekenhuiszorg. Dat is onacceptabel,' $M C$ 2006, afl. 20, p. 843.

\section{Kromhout e.a. 2014}

M. Kromhout e.a., Kinderen buiten beeld. Een onderzoek naar de woon- en leefsituatie van ongedocumenteerde kinderen. Utrecht: Stichting Los, 2014.

\section{Laban e.a., Tijdschrift voor Psychiatrie 2005/11, p. 743-752}

C. Laban e.a., Invloed van de duur van de asielprocedure op de prevalentie van psychiatrische stoornissen bij Iraakse asielzoekers in Nederland, Tijdschrift voor Psychiatrie 2005, afl. 11, p. 743-752.

\section{Laconi, De Stentor 24 november 2019}

Paolo Laconi, 'Het broeit in Balkbrug: onrust over komst illegale vluchtelingen met psychiatrische problemen', De Stentor 24 november 2019.

\section{Lahuis e.a. European Journal of Psychotraumatology 2019, 10:1}

A. M. Lahuis e.a., Undocumented asylum seekers with posttraumatic stress

disorder in the Netherlands, European Journal of Psychotraumatology 2019, 10:1, doi: 10.1080/20008198.2019.1605281.

\section{Legemaate \& Widdershoven}

J. Legemaate \& G.J. Widdershoven, Basisboek Ethiek \& Recht in de gezondheidszorg, Amsterdam: Boom uitgevers, 2016.

\section{Leenen 1997}

H.J.J. Leenen, Recht op zorg voor de gezondheid. Preadvies Vereniging voor Gezondheidsrecht, 1997.

\section{Leenen e.a. 2017}

H.J.J. Leenen e.a., Handboek Gezondheidsrecht, Houten: Boom Juridische Uitgevers 2017.

\section{Lodder 2018}

G.G. Lodder, Vreemdelingenrecht in vogelvlucht. Over toelating en verblijf van vreemdelingen in Nederland, Den Haag: Sdu 2018.

\section{Da Lomba 2014, EJHL 2014 afl. 4, p. 339-364}

S. Da Lomba, 'Vulnerability, Irregular Migrants' Health-Related Rights and the European Court of Human Rights', EJHL 2014, afl. 4 p. 339-364.

\section{Mackenbach \& Stronks 2016}

J.P. Mackenbach \& K. Stronks (red.), Volksgezondheid en gezondheidszorg, Houten: Bohn Stafleu van Loghum, 2016. 
Mann e.a., 'Health and Human Rights', Health and Human Rights Journal 1994, afl. 1, p. 623, doi:10.1136/bmj.312.7036.924.

Mantouvalou, The Modern Law Review, 2009/5, p. 815-843

V. Mantouvalou, N v UK : No Duty to Rescue the Nearby Needy? The Modern Law Review, 2009, afl. 5, p. 815-843.

Matlin e.a., Public Health Reviews, 2018/27

S.A. Matlin e.a., Migrant's and refugees' health: towards an agenda of solutions, Public Health Reviews 2018, afl. 27, doi:10.1186/s40985-018-0104-9.

De Meij, NJB 2015/542

P. de Meij, 'Het recht van vreemdelingen op een menswaardig bestaan en de rol van de rechter', NJB 2015/542.

Minderhoud 1998, $A A$ 1998/9, p. 775-778

P.E. Minderhoud, 'Noot bij de Koppelingswet', $A A$ 1998, afl. 9, p. 775-778.

Minderhoud 2012, NTM/NJCM-Bull. 2012/4, p. 391-407

P.E. Minderhoud, 'Scheurtjes in de Koppelingswet', NTM/NJCM-Bull. (37) 2012, afl. 4, p. 391407.

Murtagh, Crim Law and Philos 2012/1, p. 21-30

K.J., Murtagh, 'What is Inhuman Treatment?' Criminal Law and Philosophy (6) 2012, afl. 1, p. 21-30, doi:10.1007/s11572-011-9131-z.

Van den Muijsenbergh, Lagro-Janssen \& Assmann, MC 27 juni 2006

M. van den Muijsenbergh, T. Lagro-Janssen \& P. Assmann, 'Illegaal moet ook geholpen. Ook zonder papieren heeft een mens recht op medische zorg', MC 27 juni 2006.

NJCM 1999, afl. 6

'Koppelingswet: wachten tot het kalf verdronken is?', NJCM-Bulletin 1999, afl. 6.

Obbing, Trouw 20 februari 2017

Hanne Obbing, 'Zonder adres geen zorgverzekering. En ook geen plek om rustig te sterven', Trouw 20 februari 2017

\section{Onarheim e.a., BMJ Global Health 2018;3:e001031}

K.H. Onarheim e.a., 'Towards universal health coverage: including undocumented migrants', BMJ Global Health 2018;3:e001031. Published online 2018 Oct 8, doi:10.1136/bmjgh-2018001031.

\section{Oomen 2019}

B. Oomen, 'Illegalen, ofwel rechtenmensen', in: C. Elion-Valter, Bart van Klink, Sanne Taekema (Red.), Wegen der vrijheid, Liber amicorum voor Willem Witteveen, Den Haag: Boom Juridisch 2019.

\section{Ooms e.a., BMC International Health and Human Rights 2014/3}

G. Ooms e.a., 'Is universal health coverage the practical expression of the right to health care?', BMC International Health and Human Rights 2014, afl. 3, doi:10.1186/1472-698X-14-3. 


\section{Den Otter \& Tavenier, $M C$ 2006/34, p. 1316-1318}

Gelijke rechten op gezondheidszorg. Aan uitgeprocedeerde asielzoekers mag geen zorg worden onthouden, MC 2006, afl. 34, p. 1316-1318.

\section{Pace 2009}

P. Pace, Migration and the Right to Health: A Review of International Law, International Migration Law Series No. 19, Genève: International Organization for Migration (IOM) 2009.

\section{Peers, European Journal of Migration and Law 2015/4 p. 289-304}

S. Peers, 'Irregular Migrants: Can Humane Treatment be Balanced against Efficient Removal?' European Journal of Migration and Law 2015, afl. 4 p. 289-304, doi: 10.1163/1571816612342083.

Pilon, One World 30 maart 2020

Marlies Pilon, 'Citroen helpt tegen corona, lezen nieuwkomers', OneWorld 30 maart 2020.

\section{Pluymen 2008}

M.H. Pluymen, Een rechtssociologisch onderzoek naar de rechtvaardiging en praktijk van uitsluiting van vreemdelingen van voorzieningen (diss. Radboud Universiteit Nijmegen), Boom Juridische Uitgevers 2008.

\section{Portegies-Damave, $A A$ 1998/9, p. 768-778}

M.E. Portegies-Damave, 'De Koppelingswet', $A A$ 1998, afl. 9, p. 768-778.

\section{Rechel e.a. 2011}

B. Rechel e.a., editors. Migration and health in the European Union. Maidenhead, UK: Open University Press for the European Observatory on Health Systems and Policies, 2011.

\section{Riedel 2009}

E. Riedel, 'The Human Right to Health: Conceptual Foundations', in Clapham et al. (eds.), Realizing the Right to Health, Zürich: Rüffer und Rub, 2009.

\section{Rietveld e.a., $N T v G$ 2019;163:D3729}

M.P. Rietveld e.a., 'Gezondheidsproblemen van migranten zonder geldige verblijfsvergunning. Somatische en psychiatrische klachten bij migranten die vragen om onderdak, NTvG 2019;163:D3729.

\section{Roscam Abbing 1979}

H.D.C. Roscam Abbing, International Organizations in Europe and the Right to Health Care, Kluwer: Deventer, 1979.

\section{Roscam Abbing, TvGR 1995/6, p. 346-347}

H.D.C. Roscam Abbing, 'De civielrechtelijke hulpverleningsplicht van arts en ziekenhuis in een publiekrechtelijk jasje', TvGR 1995, afl. 6, p. 346-347.

\section{Sahadat, de Volkskrant 2019}

I. Sahadat, 'Het beste voor Mohamad', de Volkskrant 23 november 2019.

\section{Schermers, NJB 1996/2, p. 247}

H.G. Schermers, 'Overheidsverstrekkingen aan illegalen', NJB 12 januari 1996, afl. 2, p. 247. 
Schoevers e.a., International Journal of Public Health 2010/55, p. 421-428

M.A. Schoevers e.a., 'Health care utilization and problems in accessing health care of female undocumented immigrants in the Netherlands', International Journal of Public Health (55) 2010, p. 421-428, doi: 10.1007/s00038-010-0151-6.

\section{Schoevers 2011}

M. Schoevers, Hiding and Seeking. Health problems and problems in accessing health care of undocumented female immigrants in the Netherlands (diss. Nijmegen), Enschede: 2011.

\section{Simon, NJB 1987/14, p. 429-434}

H.J. Simon, 'Het uitsluiten van illegale vreemdelingen van (semi-)overheidsvoorzieningen', NJB 1987, afl. 14, p. 429-434.

\section{Sijmons, TvGR 1995/6, p. 332-345}

J.G. Sijmons, 'De civielrechtelijke hulpverleningsplicht van arts en ziekenhuis', TvGR 1995, afl. 6, p. 332-345.

\section{Sijmons 2008}

J.G. Sijmons, De stimulerende middelen van de wetgever. Ontwikkelingen in het gezondheidsrecht, (oratie Universiteit Utrecht), Den Haag: Sdu Uitgevers 2008.

\section{Sijmons \& Derckx, NJB 2010/27, p. 1398-1456}

J.G. Sijmons \& V.L. Derckx, 'Zorg aan vreemdelingen zonder papieren: een chronisch gebrek?', NJB 2010, afl. 27, p. 1398-1456.

\section{Sluyters 1989}

B. Sluyters, De gezondheidszorg en het strafrecht. Preadvies. Utrecht: Vereniging voor Gezondheidsrecht, 1989: 10-1.

\section{Smith, BMJ Group Blogs 2008}

R. Smith, The end of disease and the beginning of health. BMJ Group Blogs 2008, https://blogs.bmj.com/bmj/2008/07/08/richard-smith-the-end-of-disease-and-the-beginning-

\section{of-health/}

\section{Snippe \& Mennes 2018}

J. Snippe \& R. Mennes, Vooronderzoek data en methoden illegalenschatting, WODC, ministerie van Justitie en Veiligheid, Den Haag: september 2018.

\section{Søvig, EJHL 2011/1, p. 43-54}

K.H. Søvig, 'Provision of Health Services to Irregular Migrants with a Special Focus on Children', EJHL, 2011, afl. 1, p. 43-54.

\section{Van der Stel 2016, MC 8 juni 2016}

J. van der Stel, Definitie 'Gezondheid' aan herziening toe, MC 8 juni 2016.

\section{Stoyanova, International Journal of Refugee Law 2017/4, p. 580-616}

V. Stoyanova V., How Exceptional Must 'Very Exceptional' Be? Non-Refoulement, SocioEcomic Deprivation, and Paposhvili v Belgium', International Journal of Refugee Law 2017 afl. 4, 580-616, doi:10.1093/ijrl/eeaa30. 


\section{Straßmayr e.a., BMC Public Health 2012;12:367}

C. Straßmayr e.a., 'Mental health care for irregular migrants in Europe: barriers and how they are overcome', BMC Public Health. 2012;12:367. Published 2012 May 20. doi:10.1186/14712458-12-367

\section{Stronks e.a., BMC Public Health 2013, 13:402}

K. Stronks e.a., Unravelling the impact of ethnicity on health in Europe: the HELIUS study, BMC Public Health 13:402, doi: 10.1186/1471-2458-13-402.

Terlouw, $A A$ 2020/p. 412-418.

A. Terlouw, 'Menselijke waardigheid en rechten van niet rechtmatig verblijvenden', $A A$ 2020, afl. 4, p. 412-418.

\section{Teunissen e.a., BMJ Open 2014;4:e005738}

E. Teunissen e.a., 'Mental health problems of undocumented migrants (Ums) in the Netherlands: a qualitative exploration of help-seeking behavior and experiences with primary care', BMJ Open 2014;4:e005738, doi:10.1136/bmjopen-2014-005738.

\section{Thijssen 2009}

H.E.B. Thijssen, De juridische dissertatie onder de loep. De verantwoording van methodologische keuzes in juridische dissertatie (diss. Tilburg University), Den Haag: Boom Juridische Uitgevers 2009.

\section{Toebes, Migrantenrecht 1996/3, p. 197-199}

B.C.A. Toebes, 'Wijziging wetsvoorstel Koppelingswet en de toegang tot de gezondheidszorg: een doekje voor het bloeden', Migrantenrecht 1996; 11(3), p. 197-199.

\section{Toebes 1999}

B.C.A. Toebes, The right to Health as a Human Right in International Law, (diss. Utrecht). Antwerpen-Groningen-Oxford: Intersentia Hart 1999.

\section{Toebes 2001}

B.C.A. Toebes, 'The right to health', in Asbjørn Eide, Catarina Crause en Allan Rosas (eds.), Economic, Social and Cultural Rights: A Textbook (Second Rivised Edition), Dordrecht/Boston/Londen: Martinus Nijhoff Publishers, 2001, p. 169-190.

\section{Toebes 2002}

B.C.A. Toebes, 'Inspanning en spanning: multiculturaliteit, (reproductieve) gezondheid en het VN-Vrouwenverdrag', in: R. Holtmaat (eindredactie), Een verdrag voor alle vrouwen. Verkenningen van de betekenis van het VN-Vrouwenverdrag voor de multiculturele samenleving, E-QUALITY, oktober 2002.

\section{Toebes 2016}

B.C.A. Toebes, 'Schets van het internationaal gezondheidsrecht', $T v G R$ 2016, p. 513-526.

\section{Toonders e.a., $M C$ 2020/10, p. 24-28}

S. Toonders e.a., 'Ook patiënt zonder papieren heeft recht op zorg', $M C$ 10/2020, p. 24-28.

\section{Vermaat, $T v G R$ 2003/1, p. 3-8}

M.F. Vermaat, 'Toegang tot de gezondheidszorg voor illegalen goed geregeld?', $T v G R$ 2003, afl. 1, p. 3-8. 


\section{Vermeulen 2019}

B.P. Vermeulen, Commentaar op artikel 22 van de Grondwet, in: E.M.H. Hirsch Ballin en G. Leenknegt (red.), Artikelsgewijs commentaar op de Grondwet, webeditie 2019 (nederlandrechtsstaat.nl).

\section{Van de Vathorst 1999}

S. van de Vathorst, 'Medische beroepsethiek en de zorg voor onverzekerde illegalen. In: A. van Es, E.K. Fogelberg en M.E.T.C. van den Muijsenbergh, 'Illegale vreemdelingen op uw spreekuur', Johannes Wier Stichting voor Mensenrechten en Gezondheidszorg, Amersfoort: 1999, p. 20-21.

\section{De Visser, de Volkskrant 17 juli 2006}

E. de Viser, 'AMC vindt oplossing voor langdurige zorg aan illegalen', de Volkskrant 17 juli 2006.

\section{De Vito e.a. 2015}

E. de Vito e.a., Public Health aspects of migrants' health: a review of the evidence on health status for undocumented migrants in the European Region. Kopenhagen: WHO Regional Office for Europe, 2015.

\section{Vonk 2015}

G.J. Vonk, 'Kwetsbare verzorgingsstaat. Over juridische aspecten van ernstige armoede in Nederland', NJB 2015/19, p. 1280-1287.

\section{Voogt e.a. 1992}

W.C. Voogt e.a., 'De Inspectie voor de Gezondheidszorg en de problematiek van illegalen', in: Illegale vreemdelingen op uw spreekuur, Johannes Wier Stichting, Amersfoort 1999, p. 22.

\section{Voogt \& Mensinga, Vakblad Sociaal Werk 2019, afl. 6, p. 23-25}

E. Voogt E. \& M. Mensinga, 'Toegang tot alle zorg. Zes casussen uit de praktijk van Lampion', Vakblad Sociaal Werk 2019, afl. 6, p. 23-25.

\section{Vorhaus 2002}

J. Vorhaus 'On Degradation. Part One: Article 3 of the European Convention on Human Rights' (2002) 31 Common Law World Review 374.

\section{Wallage 2014}

B. Wallage, Inhumaan vreemdelingenbeleid: de zieke vreemdeling. NJB 23-03-2014, afl. 12, 781-784.

\section{Wegelin, A\&MR 2017/2.}

B. Wegelin, EHRM gooit roer om in medische zaken. Arrest Paposhvili verbetert verblijfspositie ernstig zieke vreemdelingen, $A \& M R$ 2017, nr. 2.

\section{Weissbrodt \& Meili, Refugee Survey Quaterly 2010/4, p. 34-58}

D. Weissbrodt \& S. Meili, 'Human Rights and Protection of non-citizens: whether universality and indivisibility of rights?' Refugee Survey Quaterly 2010, afl. 4, p. 34-58.

\section{Wilkinson \& Marmot 2003}

R. Wilkinson \& M. Marmot (red), Social determinants of health: the solid facts, 2nd ed. Oxford: Oxford University Press 2003. 
Van Wijlick, MC 2006/39, p. 1535

E.H.J. van Wijlick, Onverzekerden krijgen andere zorg, $M C$ 2006, afl. 39, p. 1535.

Winters e.a. 2018, BMC Health Services Research 2018/30

M. Winters e.a., 'A systematic review on the use of healthcare services by undocumented migrants in Europe', BMC Health Services Research 2018, afl. 30, doi:10.1186/s12913-018$2838-y$.

\section{Wolswinkel e.a. 2019}

J. Wolswinkel e.a., Ongedocumenteerde patiënten bij de huisarts. Onderzoek naar de morbiditeit van ongedocumenteerde patiënten en de daaraan gegeven zorg door Nederlandse huisartsen in enkele grote steden. Nijmegen: Radboud Universitair Centrum, 2019.

\section{Wouters 2009}

C.W. Wouters, International Legal Standards for the Protection from Refoulement, Intersentia, Leiden: 2009.

\section{Wouters \& Vidal}

J. Wouters \& M. Vidal, Het Arbeidsmigrantenverdrag van de Verenigde Naties: onbekend en onbemind? in D. Pieters, J. Put, P. Schoukens, Y. Stevens en D. Simoens (eds.), Sociale zekerheden in vraagvorm. Liber amicorum Jef Van Langendonck, Antwerpen, Intersentia, 2005, 593-605.

\section{Zwaan e.a. 2020}

K. Zwaan e.a., Nederlands Migratierecht, Den Haag: Boom Juridisch 2020.

\section{Rapporten}

\section{Amnesty International 2013}

Amnesty International, Vreemdelingendetentie in Nederland: mensenrechten als maatstaf, Amnesty International, Amsterdam: september 2013.

\section{Avance 2018}

Avance, Leefomstandigheden van kinderen in asielzoekerscentra en gezinslocaties. Onderzoek uitgevoerd in opdracht van het OCA en de Werkgroep Kind in azc. Rapportage II: onderzoeksopzet en resultaten, 2018.

\section{AVCZ 2012}

Adviescommissie voor Vreemdelingenzaken, Recht op menswaardig bestaan. Advies over opvang en bijstand voor niet rechtmatig verblijvende vreemdelingen en rechtmatig verblijvende vreemdelingen zonder recht op voorzieningen, ACVZ, Den Haag: maart 2012.

\section{Castelijns e.a. 2011}

E. Castelijns E. e.a., Evaluatie van de bijdrageregeling van artikel $122 a$ van de Zorgverzekeringswet. Eindrapport, Berenschot 2011.

\section{Commissie Evaluatie Vreemdelingenwet 2000}

Commissie Evaluatie Vreemdelingenwet 2000, Wetenschappelijk Onderzoek- en Documentatiecentrum, Kiwa Management Consultants, Bureau Boekhoorn Sociaal- 
wetenschappelijk Onderzoek, Evaluatie Vreemdelingenwet 2000, Terugkeerbeleid en Operationeel Vreemdelingentoezicht, Den Haag: Boom Juridische Uitgevers, 2004.

\section{Commissie Klazinga 2007}

Commissie Medische zorg voor (dreigend) uitgeprocedeerde asielzoekers en illegale vreemdelingen. Arts en Vreemdeling, Utrecht: KNMG 2007.

\section{Commissie Smeets 2005}

Rapport van de Landelijke Commissie Medische Aspecten van het Vreemdelingenbeleid, Tsg, 83.

\section{Commissie Zeevalking 1991}

Eindrapport Commissie Binnenlands Vreemdelingentoezicht (commissie Zeevalking), 18 maart 1991.

\section{Dokters van de Wereld \& Artsen zonder Grenzen 2014}

Dokters van de Wereld \& Artsen zonder Grenzen, 'Assessment of unmet needs regarding access to health care of undocumented persons in the Netherlands', Amsterdam: Dokters van de Wereld/Artsen zonder Grenzen, 2014.

\section{Dokters van de Wereld 2016}

Dokters van de Wereld, 'Status Quo. Een literatuurstudie naar gezondheidsdeterminanten van ongedocumenteerde migranten in Nederland', Amsterdam: 2016.

\section{Dokters van de Wereld 2017}

Dokters van de Wereld, Toegang tot mondzorg voor ongedocumenteerde migranten in Nederland. Een overzicht van lokale particuliere initiatieven, Extern document. Amsterdam: 2017.

\section{Dokters van de Wereld 2018}

Dokters van de Wereld, De deur naar zorg. Het recht op gezondheid en zorg voor ongedocumenteerde migranten, Amsterdam: 2018.

\section{Dokters van de Wereld 2019}

Dokters van de Wereld, Kiezen voor elkaar. Betere toegang tot mondzorg voor kwetsbare mensen, Amsterdam: 2019.

\section{'Een ongezonde wet' 2018}

Amnesty International, Dokters van de Wereld en Stichting LOS -Meldpunt Vreemdelingendetentie, Een ongezonde wet. Gezondheidszorg en wet terugkeer en vreemdelingenbewaring, Amsterdam: 11 december 2018.

\section{FRA 2011}

European Union Agency for Fundamental Rights, Fundamental rights of migrants in an irregular situation in the European Union, Comparative Report, Wenen: november 2011.

\section{FRA 2015}

European Union Agency for Fundamental Rights, Cost of exclusion from healthcare - The case of migrants in an irregular situation, Wenen: september 2015. 


\section{Van der Heijden e.a. 2015}

P.G.M. van der Heijden, M. Cruyff, G.H.C. van Gils: Schattingen illegaal in Nederland verblijvende vreemdelingen 2012-2013, WODC, Ministerie van Veiligheid en Justitie, 2015.

\section{Gezondheidsraad 2012}

Gezondheidsraad, De mondzorg van morgen. Den Haag: Gezondheidsraad, 2012: publicatienr. 2012/04.

\section{Gezondheidsraad 2016}

Gezondheidsraad 24 juni 2016, Briefadvies Geestelijke gezondheid van vluchtelingen, Publicatienr. 2016/01.

\section{IGZ 2006}

IGZ, Medische advisering in het kader van het vreemdelingenbeleid door BMA (rapport), Den Haag: 2006.

\section{IGZ 2014}

IGZ, Verantwoorde medische zorg in detentie- en uitzetcentra. Signaleren van psychische kwetsbaarheid moet systematischer, Utrecht: februari 2014.

\section{IGZ en IVenJ 2017}

IGZ en IVenJ, Nader onderzoek naar de zorgverlening aan Renata A., Utrecht: januari 2017.

\section{IOM 1998}

IOM, The Future of Public Health: the Institute of Medicine's 1998 report, Washington, DC: National Academy Press.

\section{Kennisplatform Integratie \& Samenleving 2018}

L. van Hal \& F. Stoutjesdijk, Alleen krijg je het niet voor elkaar. Een verkenning van medisch noodzakelijke zorg voor ongedocumenteerde migranten in Nederland, Kennisplatform Integratie \& Samenleving, Verwey-Jonker Instituut, Utrecht: 2018.

\section{Nationale ombudsman 2013}

Nationale ombudsman, Medische zorg vreemdelingen. Over toegang en continuïteit van medische zorg voor asielzoekers en uitgeprocedeerde asielzoekers. Rapportnummer 2013/125, 2013.

\section{Nivel 1999}

I. Kulu Glasgow e.a., Illegalen aan de 'poort' van de gezondheidszorg: toegankelijkheid en knelpunten in de zorg van huisartsen, verloskundigen en spoedeisende hulpafdelingen, Utrecht: Nivel 1999.

\section{Nivel 2009}

T. Veenema, T. Wiegers \& W. Devillé, Toegankelijkheid van gezondheidszorg voor 'illegalen' in Nederland: een update, Nivel, Utrecht: 2009.

\section{NRV 1995}

Nationale Raad voor de Volksgezondheid en het Overlegorgaan Gezondheidszorg en Multiculturele samenleving: Gezondheidszorg voor illegaal verblijvende vreemdelingen. Advies over de gevolgen van de Koppelingswet voor de gezondheidszorg, Zoetermeer: NRV juli 1995. 


\section{Onderzoeksraad voor Veiligheid 2014}

Onderzoeksraad voor Veiligheid, Veiligheid van vreemdelingen, Den Haag: april 2014.

\section{Pharos 2010}

Pharos, Ongedocumenteerde kinderen en de toegang tot ziekenhuiszorg. Onderzoeksrapport. Utrecht: 2010.

\section{Pharos 2016}

Pharos, Factsheet Laaggeletterdheid en beperkte gezondheidsvaardigheden (pharos.nl).

\section{Pharos 2019}

Pharos, Toegang tot zorg voor ongedocumenteerde migranten. Wat helpt om zorg te krijgen? Pharos, Expertisecentrum Gezondheidsverschillen, Utrecht: mei 2019.

\section{PICUM 2016}

PICUM, The sexual and reproductive health rights of undocumented migrants. Narrowing the gap between their rights and the reality in the EU, Brussel: 2016.

\section{PICUM 2019}

PICUM, Protecting undocumented children: Promising policies and practices from governments, Brussel: 2019.

\section{Priebe e.a. 2016}

S. Priebe e.a., Public health aspects of mental health among migrants and refugees: a review of the evidence on mental health care for refugees, asylum seekers and irregular migrants in the WHO European Region, Kopenhagen: WHO Regional Office for Europe; 2016 (Health Evidence Network (HEN) Synthesis Report 47).

\section{Pro Facto 2018}

$\mathrm{H}$. Winter et al, Rapportage Onderdak en opvang door Rijk en gemeenten van vertrekplichtige vreemdelingen en de invloed daarvan op terugkeer, Groningen: april 2018.

Rapport Commissie 'Langdurig verblijvende vreemdelingen zonder verblijfsrecht' 2019 Rapport Commissie 'Langdurig verblijvende vreemdelingen zonder verblijfsrecht', Rijksoverheid, Den Haag: 2019.

\section{RIVM 2010}

G.P. Wester e.a. (red.), Zorgbalans 2010. De prestaties van de Nederlandse zorg, RIVM, Bilthoven: 2010.

\section{SER 2017}

Sociaal Economische Raad, Opgroeien zonder armoede, Advies 17/03, 2017.

\section{Reijneveld \& Van Herten 2000}

S.A. Reijneveld en L.M. van Herten, Toegankelijkheid van zorg voor illegalen, Leiden: TNO Preventie en Gezondheid, 2000.

\section{TNO 2001}

L.M. van Herten, S.A. Reijneveld \& J.A.J. Borghouts, Financiering van zorg voor illegalen. Leiden: TNO Preventie en Gezondheid, 2001. 


\section{V\&W 1996}

Vereniging voor Volksgezondheid en Wetenschap, Zorg aan illegalen. Notitie en standpunt van de Vereniging voor Volksgezondheid en Wetenschap, februari 1996.

\section{Werkgroep kind in azc 2014}

Werkgroep Kind in azc, Het is hier in één woord gewoon ...stom!; Onderzoek naar het welzijn en perspectief van kinderen en jongeren in gezinslocaties, 2014.

\section{Werkgroep medische zorg in vreemdelingendetentie 2014}

Werkgroep medische zorg in vreemdelingendetentie, Geketende zorg. Gezondheidszorgen in vreemdelingendetentie, Amsterdam: 2014.

\section{WHO 2010}

WHO Europe, Poverty and social exclusion in the WHO European Region: health systems respond, Kopenhagen: WHO Regional Office for Europe, 2010.

\section{WHO 2018a}

WHO Regional Office for Europe, Report on the health of refugees and migrants in the WHO European Region. No Public Health without Refugee and Migrant Health, Kopenhagen: WHO Regional Office for Europe, 2018.

\section{WHO 2018b}

WHO Regional Office for Europe, Health of refugee and migrant children. Technical guidance. Kopenhagen: WHO Regional Offie for Europe, 2018.

\section{Ziekenfondsraad 1992}

Ziekenfondsraad 25 juni 1992, Advies inzake toegankelijkheid sociale ziektekostenverzekeringswetten voor illegaal in Nederland verblijvende vreemdelingen, ZFR $553 / 92$.

\section{Ziekenfondsraad 1995}

Ziekenfondsraad 23 maart 1995, Advies inzake koppelen van verzekeringsplicht ingevolge de sociale ziektekostenverzekeringswetten aan het rechtmatig verblijf van vreemdelingen in Nederland, 1995/660a.

\section{Zorginstituut Nederland 2020}

Zorginstituut Nederland, Tolkvoorziening voor anderstaligen in de geneeskundige geestelijke gezondheidszorg, Diemen: 14 april 2020. 


\section{Jurisprudentielijst}

VN-Mensenrechtencomité

- VN-Mensenrechtencomité 9 april 1987, 172/1984 (Broeks/Nederland).

- VN-Mensenrechtencomité 9 april 1987, 182/1984 (Zwaan-de Vries/Nederland).

- VN-Mensenrechtencomité 14 september 2006, 1314/2004 (O'Neill and Quinn/Ierland).

- VN-Mensenrechtencomité 7 augustus 2018, 2348/2014 (Toussaint/Canada).

- VN-Mensenrechtencomité 26 maart 2019, 2498/2014, RSV 2019/262, m.nt. P.E. Minderhoud (Abdoellaevna/Nederland).

Committee Against Torture

- CAT 20 november 2015, 613/2014 (F.B./Nederland).

- CAT 27 april 1994, 13/1993 (Mutombo/Zwitserland.

Europese Commissie voor de Rechten van de Mens

- $\quad$ Greek Case (1969), YECHR 1, p 186.

Europees Hof voor de Rechten van de Mens

- EHRM 18 januari 1978, nr. 5310/71 (Ierland/Verenigd Koninkrijk).

- EHRM 9 oktober 1979, nr. 6289/73 (Airy/lerland).

- EHRM 26 maart 1985, ECLI:NL:XX:1985:AC8813, NJ 1985, 525, m.nt. E.A. Alkema (X.\&Y./Nederland).

- EHRM 28 januari 1994, nr. 17549/90 (Hurtado/Zwitserland).

- EHRM 19 mei 1994, nr. 23634/94 (Tanko/ Finland).

- EHRM 16 september 1996, nr. 17371/90 (Gaygusuz/Oostenrijk), Reports 1996-IV.

- EHRM 2 mei 1997, ECL:NL:XX:1997:AB8007, NJ 1998, 582, RV 1997/70 (D./Verenigd Koninkrijk (St. Kitts)).

- $\quad$ EHRM 28 juli 1999, nr. 25803/94 (Selmouni/Frankrijk).

- EHRM 4 mei 2000 (ontv.), nr. 45305/99 (Powell/Verenigd Koninkrijk).

- EHRM 26 oktober 2000, nr. 30210/96 (Kudla/Polen).

- $\quad$ EHRM 6 februari 2001, nr. 30240/96, EHRC 2001/25, JV 2001/103 (Bensaid/Verenigd Koninkrijk).

- EHRM 3 mei 2001, ECLI:CE:ECHR:2001:0503DEC005599600, (Domenech Pardo/Spanje).

- EHRM 29 april 2002, ECLI:NL:XX:2002:AP0678, NTM/NJCM-bull. 2002, p. 910, m.nt. E. Myer (Pretty/Verenigd Koninkrijk).

- EHRM 24 juni 2003, nr. 13669/03, NJCM-Bulletin 2003, p. 1015, m.nt. E. Myer (Francisco J. Arcila Henao/Nederland).

- EHRM 16 maart 2004, nr. 38865/02 (Nasimi/Zweden).

- EHRM 29 juni 2004, nr. 7702/04 (Salkic e.a./Zweden).

- EHRM 25 november 2004, nr. 26629/04, NTM/NJCM-bull. 2006, p. 206, m.nt. Gerrie Lodder (Amegnigann/Nederland).

- EHRM 27 september 2005, nr. 17416/05 (Hukic/Zweden). 
- EHRM 4 januari 2005, nr. 14462/03 (Pentiacova e.a./Moldavië).

- EHRM 25 oktober 2005, nr. 58453/00, EHRC 2005/121, m.nt. F.M.J. den Houdijker (Niedzwiecki/Duitsland).

- EHRM 3 mei 2007, nr. 2778/02 (Hüseyn Yildirim/Turkije).

- EHRM, 28 februari 2008, ECLI:NL:XX:2008:BC6246 (Saadi/Italië).

- EHRM (Grote Kamer) 27 mei 2008, ECLI:NL:XX:2008:BD6647, GJ 2008/99, m.nt. A.C. Hendriks (N./Verenigd Koninkrijk).

- EHRM 10 maart 2009, nr. 45413/07 (Anakomba Yula/ België).

- EHRM 27 september 2009, nr. 56328/07 (Bah/Verenigd Koninkrijk).

- EHRM 16 februari 2010, 7078/02, EHRC 2010/48, m.nt. C.H. Slingenberg (V.D./Roemenië).

- EHRM 23 maart 2010, ECLI:NL:XX:2010:BM6763 (Oyal/Turkije).

- EHRM 27 januari 2011, nr. 10907/04 (Iordanovi/Bulgarije).

- EHRM 10 maart 2011, nr. 2700/10, EHRC 2011, 84, m.nt. J.H. Gerards (Kiyutin/Rusland).

- $\quad$ EHRM 21 juni 2011, nr. 5335/05 (Ponomaryovi/Bulgarije).

- EHRM 20 december 2011, Requête no 10486/10 (Yoh-Ekale Mwanje/Belgium).

- EHRM 23 februari 2012, nr. 27765/09, A\&MR 2012, Nr. 3 - 141, m.nt. M. den Heijer (Hirsi Jamaa e.a. Others/Italië).

- EHRM 24 april 2012, nr. 19202/03 (Iliya Petrov/ Bulgarije) (beschikbaar in het Frans).

- EHRM 30 oktober 2012, nr. 57375/08, EHRC 2013/15, m.nt. A.C. Hendriks (P. \& S./Polen).

- EHRM 9 april 2013, ECLI:NL:XX:2013:381, EHRC 2013/142, m.nt. B.C.A. Toebes (Mehmet Şentürk \& Bekir Şentürk/Turkije).

- EHRM 16 april 2013, nr. 17299/12 (Aswat/Verenigd Koninkrijk).

- EHRM 5 december 2013, ECLI:NL:XX:2013:291, GJ 2014/5, m.nt. A.C. Hendriks (Arskaya/Oekraïne).

- EHRM (Grote Kamer) 27 februari 2014, nr. 70055/10 (S.J./België).

- EHRM 17 juli 2014, ECLI:NL:XX:2014:564 (Centre for Legal Resources on behalf of Valentin Câmpeanu/ Roemenië), EHRC 2014/212, m.nt. H. De Vylder.

- $\quad$ EHRM 27 januari 2015, EHRC 2015/80, m.nt. B.C.A. Toebes (Genç/Turkije).

- EHRM 26 februari 2015, nr. 1412/12, JV 2015/107 (M.T./Zweden).

- $\quad$ EHRM Grote Kamer 19 maart 2015, nr. 70055/10 (S.J./België).

- EHRM, 28 september 2015, nr. 23380/09, EHRC 2015/236 m.nt. S. Smet (Bouyid/ België).

- EHRM 13 december 2016 (Grote Kamer), ECLI:CE:ECHR:2016:1213JUD004173810, $J V$ 2017/22, m.nt. B.E.P. Myer (Paposhvili).

- EHRM 19 december 2017, ECLI:CE:ECHR:2017:1219JUD005608013, EHRC 2018/47, m.nt. L. Lavrysen (Lopes de Sousa Fernandes/Portugal).

- $\quad$ EHRM 15 januari 2019, 37115/11, ECLI:CE:ECHR:2019:0115DEC003711511, EHRC 2019/100, m.nt. P.E. Minderhoud (Yesthla/Nederland).

- EHRM 1 oktober 2019, ECLI:CE:ECHR:2019:1001JUD005746715, JV 2020/2, m.nt. G.J. Dijkman (Savran/Denemarken).

Europees Comité voor Sociale Rechten

- ECSR 8 september 2004, 14/2003, JV 2005/339 m.nt. CAG (FIDH/Frankrijk). 
- ECSR 12 februari 2008, 47/2008, NTM/NJCM-bull. 2010, m.nt. A. Buyse (DCI/Nederland).

- ECSR 3 december 2008, 46/2007, GJ 2009/84 m.nt. A.C. Hendriks (ERRC/Bulgarije).

- ECSR 23 oktober 2012, 69/2011, EHRC 2013/16 m.nt. G.J.W. Pulles (DCI/ België).

- ECSR 1 juli 2014, 90/201, JV 2015/24, m.nt. C.H. Slingenberg (CEC/Nederland).

Hof van Justitie van de Europese Unie

- HvJ EU 18 december 2014, nr. C-542/13, ECLI:EU:C:2014:2452, JV 2015/23, m.nt. H. Battjes ((M'Bodj/België).

- HvJ EU 11 november 2014, C-333/13 (Dano) ECLI:EU:C:2014:2358.

- HvJ EU 18 december 2014, nr. C-562/13, ECLI:EU:C:2014:2453, EHRC 2015/50, m.nt. M. den Heijer, $J V$ 2015/59 m.nt. F.F. Larsson (Abdida).

- HvJ EU 16 februari 2017, nr. C-578/16 PPU, ECLI:EU:C:2017:127, JV 2017/94 m.nt. S.G. Kok.

Hoge Raad

- HR 12 februari 2010, ECLI:NL:PHR:2010:B19729, BNB 2010/133, m.nt. P. Kavelaar.

- $\quad$ HR 2 maart 2011, TvGR 2001/16.

- $\quad$ HR 21 september 2012, ECLI:NL:HR:2012:BW5328, JV 2012/458, m.nt. mr. C.H. Slingenberg.

- $\quad$ HR 23 november 2012, ECLI:NL:HR:2012:BW7740, JV 2013/115, m.nt. P.E. Minderhoud.

Afdeling bestuursrechtspraak van de Raad van State

- ABRvS 11 oktober 2006, ECLI:NL:RVS: 2006:AY9897, GJ 2006/148, m.nt. V.L. Derckx, JB 2006/321, m.nt. H. Peters, JIN 2007/45, RZA 2006, 196, AB 2007/81, m.nt. I. Sewandono.

- $\quad$ ABRvS, 19 april 2007, LJN-nr. BA4289.

- ABRvS 30 januari 2014, ECLI:NL:RVS:2014:378, JV 2014/393, m.nt. P.E. Minderhoud.

- $\quad$ ABRvS 18 januari 2017, ECLI:NL:RVS:2017:105.

- ABRvS 28 september 2017, ECLI:NL:RVS:2017:2628.

- ABRvS 28 september 2017, ECLI:NL:RVS:2017:2627.

- ABRvS 20 februari 2019, ECLI:NL:RVS:2019:515.

- $\quad$ ABRvS 29 februari 2019, ECLI:NL:RVS:2019:62.

- ABRvS 20 maart 2019, ECLI:NL:RVS:2019:903, JV2019/104, m.nt. C.H. Slingenberg.

- $\quad$ ABRvS 24 juli 2019, ECLI:NL:RVS:2019:2540, JV 2019/159.

Centrale Raad van Beroep

- $\quad$ CRvB 26 juni 2001, 99/2382, ECLI:NL:CRVB:2001:AB2276, USZ 2001/183, m.nt. Red.

- CRvB (vzr.) 8 augustus 2005, 05/3801 en 05/3803 WWB-VV, LJN AU0687, AB 2005, USZ 2005, 333, m.nt. Red. 
- CRvB 24 januari 2006, ECLI:NL:CRVB:2006:AV0197, RSV 2006/84, m.nt. G. Vonk.

- CRvB 22 december 2008, ECLI:NL:CRVB:2008:BG8789, JV 2009/99, m.nt. Minderhoud en Slingenberg.

- CRvB (vzr.) 7 juli 2009, 09/2715 WWB-VV, ECLI:NL:CRVB:2009:BJ2809, USZ 2009, 266.

- CRvB 19 april 2010, ECLI:NL:CRVB:2010:BM1992, JV 2010/292, m.nt. P.E. Minderhoud.

- CRvB 20 oktober 2010, ECLI:NL:CRVB:2010:B03581, JV 2011/90, m.nt. P.E. Minderhoud.

- CRvB 15 juli 2011, 08/6595 AKW, ECLI:NL:CRVB: 2011:BR1905, 08-6595 AKW, JV 2011/393 (m.nt. Minderhoud).

- CRvB 30 mei 2011, ECLI:NL:CRVB:2011PBQ6438, RSV 2011/232, m.nt. C.W.A.C. Bruggeman.

- $\quad$ CRvB 4 augustus 2011, nr. 10/5236 AWBZ, RSV 2011/341, m.nt. C.W.C.A. Bruggeman.

- CRvB 9 september 2011, ECLI:NL:CRVB:2011:BT1738, nr. 11/4654 AWBZ/VV, RSV 2011/336.

- $\quad$ CRvB 18 april 2012, LJN BW3240.

- CRvB 11 mei 2012, ECLI:NL:CRVB:2012:BW6227, GJ 2012/115, m.nt. A.C. Hendriks.

- CRvB 6 juni 2012, ECLI:NL:CRVB:2012:BW7703, RZA 2012/49, m.nt. C.W.C.A. Bruggeman.

- CRvB 4 juni 2014, ECLI:NL:CRVB:2014:2043.

- CRvB 16 juli 2014, ECLI:NL:CRVB:2014:2444, AB 2014/408, m.nt. C.W.C.A. Bruggeman.

- CRvB 17 december 2014, ECLI:NL:CRVB:2014:4178 AB 2015, m.nt. C.W.C.A. Bruggeman.

- CRvB 26 november 2015, ECLI:NL:CRVB:2015:3834, JV 2016/19, ECLI:NL:CRVB:2015:3803; en ECLI:NL:CRVB:2015:4093

- CRvB 29 december 2015, ECLI:NL:CRVB:2015:4903.

- CRvB 24 februari 2016, ECLI:NL:CRVB:2016:615, GJ 2016/57, AB 2016/146, m.nt. A.C. Hendriks.

- CRvB 22 januari 2017, ECLI:NL:CRVB:2017:626.

- CRvB 1 februari 2017, ECLI:NL:CRVB:2017:492, USZ 2017/113, RSV 2017/7.

\section{Rechtbanken}

- Rb. Rotterdam 16 december 2005, ECLI:NL:RBROT:2005:AV3486, GJ 2006/45, m.nt. V.L. Derckx.

- Rb. 's-Gravenhage (vzr.) 26 juli 2006, ECLI:NL:RBSGR: 2006:AY5099, GJ 2006/103, m.nt. V.L. Derckx, Bavo-RNO Groep/Staat.

- $\quad$ Rb. Zwolle-Lelystad 5 juli 2011, ECLI:NL:RBZLY:2011:BU4862, RZA 2011/124, m.nt. J. Hallie.

- $\quad$ Rb. Den Haag (vzr.) 1 februari 2016, ECLI:NL:RBDHA:2016:860.

- $\quad$ Rb. Den Haag 5 oktober 2016, ECLI:NL:RBDHA:2016:12328. 
Nationale ombudsman

- Nationale ombudsman, Verzoekschrift van de Nederlandse Vereniging van Hemofiliepatiënten te Badhoevedorp met een klacht overeen gedraging van het ministerie van Welzijn, Volksgezondheid en Cultuur, 1995. Rapportnr. 95/271. Den Haag: Bureau Nationale Ombudsman, 1995.

- Openbaar Rapport van de Nationale ombudsman d.d. 31 mei 2010, nr. 2010/132.

Centraal Tuchtcollege voor de Gezondheidszorg

- $\quad$ CTG 19 augustus 2010, LJN YG0528, GJ 2010/131, m.nt. L.E. Kalkman-Bogerd.

- $\quad$ CTG 30 januari 2014, TvGR 2014, m.nt. prof. mr. J.C.J. Dute, p. 241-248.

Geschillencommissie Zorgverzekeringen

- Geschillencommissie Zorgverzekeringen 11 februari 2015, 2013.02787, GJ 2015/49. 


\section{Curriculum vitae}

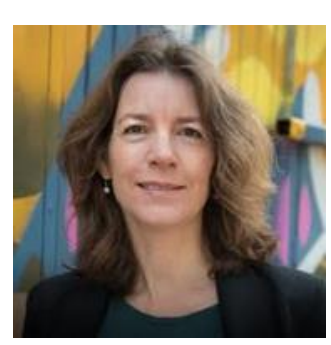

Veelke Derckx (Arnhem, 1972) studeerde Nederlands recht, richting Privaatrecht, aan de Universiteit Utrecht (doctoraal 1996). Na haar afstuderen werkte zij enkele jaren als jurist bij een verzekeringsmaatschappij. In 2000 werd Veelke docent/onderzoeker gezondheidsrecht bij de sectie Gezondheidsrecht van het Molengraaff Instituut voor Privaatrecht, Universiteit Utrecht. In deze functie nam zij deel aan een aantal wetsevaluaties in opdracht van ZonMw, waaronder de eerste evaluatie van de Wet BIG. Zij was als consultant van de Raad van Europa verbonden aan een wetgevingsproject op het gebied van de geestelijke gezondheidszorg in Moldavië. In 2008 stapte Veelke over naar het Julius Centrum, UMC Utrecht. Als Assistant Professor was zij medeverantwoordelijk voor het vak gezondheidsrecht.

In 2013 deed Veelke onderzoek naar het toezicht op preventie van onmenselijke behandeling in zorginstellingen (vakgroep Internationaal Publiekrecht, Rijksuniversiteit Groningen). Dit combineerde zij met haar functie als secretaris van de klachtencommissie van het Diakonessenhuis te Utrecht. In 2016 keerde zij terug bij het Molengraaff Instituut als docent Privaatrecht en onderzoeker gezondheidsrecht. Dit proefschrift schreef Veelke als buitenpromovendus. In de periode 2017-2018 was zij tevens werkzaam als wetenschappelijk docent bij het VUmc, afdeling Sociale Geneeskunde. Sinds september 2020 is Veelke adviseur gezondheidsrecht bij artsenfederatie KNMG. 